COLUMBIA LIBRARIES OFFSTIE
HEALH SCENGESTANDAD

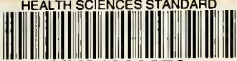

HX64060870

QM81 Em6

The B N A arranged a

\title{
RECAP
}




\section{Columbia OHniurssity}

inthe Citpaf Mrw Dark

College of poystrians and

Zlibrary

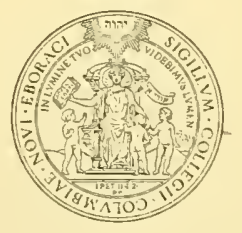






\section{Digitized by the Internet Archive in 2010 with funding from Columbia University Libraries}


Additional copies of this work may be obtained at \$1.50 each by addressing University of California Press, Berkeley, California. 
COPYRICHS APPLIED FOR, 1929

By

VICPGR E. ENARL. 
The

B $\underline{N} \underline{A}$

ARRANGED AS GN OUILIRE OF REGIONAL

AND SYSTERATIC ANATONY

by

VICTOR E. EMMEL, M.S., PH.D.

Associate Professor of Anatomy

UNIVERSITY OF CALIFORNIA 

The Basle Anatomical Nomenclature (the B N A) has been preeminently successful in the simplification of aratomical teminology. Out of a totai of 50,000 anatomisal terms about 45,000 have been eliminated as unczeasary synonyms. As a consequence, anatomical terminology as represented by the

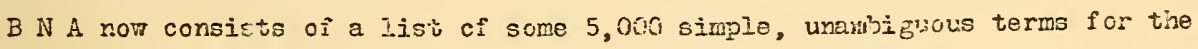
Ires aroscopic strustures of the human body.

This list of terms, intended for common use in the medical schools, is arranged on the basis of systamatic anatory. Doubtless, such an arrangement was best adapted for the purpose of bringing about this revision of terminology. On the other hand, it appears obvious that from the standpoint of practical anatomy, a regional arrangement of these terms in conjunction with their systematic tabulation would greatly exterd the usefuiness of the $B N A$. In dissecting laboratories and surgical clinics, the structures represented by the $B N A$ terms are encountered in the various regions of the body, not as anatomical systems, but as segments of these systems grouped together in certain definite regional relationships. In attempting to correlate systematic text and cadever, the one proves almost as difficult to dissect as the other.

It appears important, therefore, that the present systematic B N A should be expanded to incluce a ccrrelated regional arrangement of anatomical terms; an arrangement based upon the sequence in which the structures indicated by these terms may be exposed and demonstrated to the naked eye in actual dissection. The present wcrk represents such ax atterpt and is the outgrowth of several years of laboratory experience in which a regicnal arrargement of B N A terms in mineograph copies has been given a thorough trial and its usefulness clearly demonstrated.

The present work is presented in two parts dealing with the B N A terms 


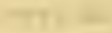

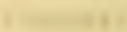

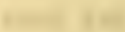

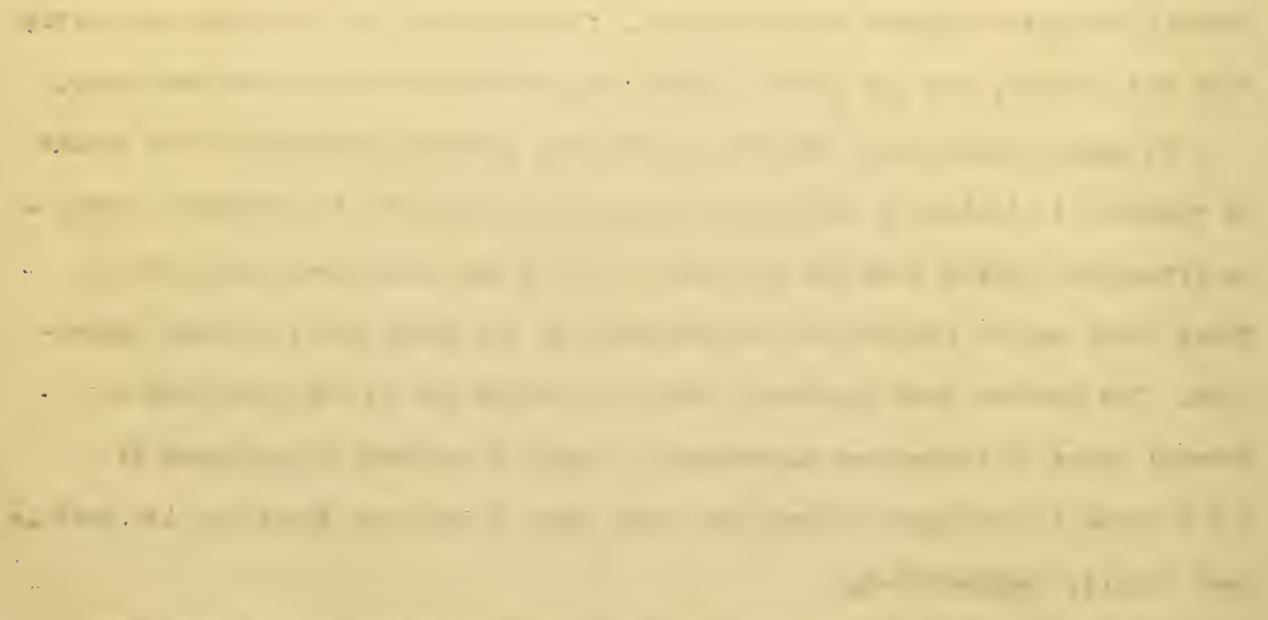

$\sqrt{2}+x^{2}$

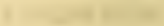

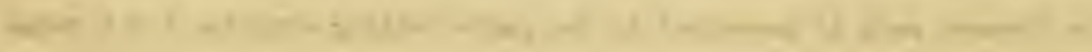


as arranged, first, on the basis of regional anatomy, and, second, on the basis of systematic anatomy, with numeral indices facilitating cross references from the one to the other. The regional arrangement is given precedence since it is in their regional relations that anatomical structures are first eacountered in practical study. The work also includes a corplete series of figures for the surface anztomy, surface projection of the skeleton and lines of skin incision for the various regions of the body (omitted in the present copy). Part I constitutes a regional resumé of anatomical structures. A tabulation for any given region necessarily involves only those structures or segments of structures which are embraced within the confines of that region. Structures such as the larger nerves or vessels extencing through two or more regions would be relisted for each region in which they occur. In general the terms have been arranged with a view to greatest utility for student and clinical reference in practical work. In presenting the subject of human anatomy it is frequenty difficult to steer a course between the scylla of too great detail and the Charybdis of a paucity of subject matter, but in any event the present tabulation may serve as a basis from which deviation may be made in either direction as the requirements of the speciai case ray dictate. In a few instances, in the interest of the student but subject to possible criticism on pedagogical grounds, the terms for structures such as some of the smaller rami of blood vessels or nerve plexuses which may be relatively of seconoary importance or especially difficult to demonstrate, are printed in smaller type (indicated by affixed double asterisks in the present mimeograph copy). With the exception of such osteological elements as are encountered in surface anatomy, terms relative to skeletal structures have been largely omitted in Part I. In this connection, the figures showing the surface projection of the skeleton should prove of value for purposes of general reference and orientation (omitted in the present copy). 

Concise statements are given for the more important incisions and dissections involved in the demonstration of the structures as listed for each region. The order in which these regions and their component structures are desit with

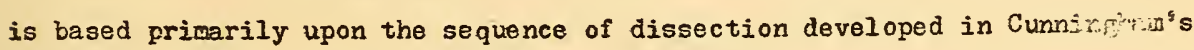
Manual of Practical Anatomy, which may be regarded as representing a meinst of procedure prevalent in the jajority of American and English anatomizal laboratories. From the standpoint of systematic anatomy, it may not bo a matter of such great importance as to what sequence may be followed in cissection so long as the structures in question are really exposed and observed. From the standpoint of regional anatomy, however, the subject presents quite a different aspect. In the latter case, the structures should be exposed in a sequence most favorable for the observation of those structural relationships which are of greatest practical significance. Toward this end, therefore, the methods of dissection in general should represent the culmination of the best available anatomical and surgical experience and this finds perhaps its best expression at the present time in the work of the British and more especially of the Edinburgh school of anatomists. Barkers' Laboratory Manual of Human Anatomy, 1904, which in method is in close agreement with that of the Edinturgh School, has also been a source of valuable suggestions, especially in the case of the brain and sense organs.

Part II constitutes a systematic resume of anatomical structures and, with the exception of certain minor changes, is based upon the systerratic arrangement of the B N A terms as originally published by His, 1895. This arrangement, as emphasized by Dr. F. T. Lewis, Stohr's Textbook of Histology, 6th edition, p.vi, is such as to furnish "an excellent means by which students may review anatomy". In Part I cure of the terms are in Latin, while others are anglicized. In a few instances it has been necessary to employ a term not listed in the $B N \dot{~}$, as for example in the case of the surgical triangles of the neck. Such 

terms can, however, always be recognized through the absence of cross reference numerals. In Part II all of the BN A terms have been retained in their original Latin form. In the case of Part $I$, that form of the term has been used which appears most prevalent in the majority of the standard English and American anatomical texts and in the conversational language of the laboratory and clinic. Where this is not clear, the Latin term is given. In the event of differences in different texts, ragarding the terms which are anglicized, the cross references to Part II facilitate a ready reference to the equivalent Latin form, as for example in the case of stomach and ventriculus, or spleen and lien. In this connection it must be recognized that as yet there is no authoritative list of English equivalents for the $B$ N $A$ and no unanimity of agreement as to the usage of Latin or anglicized forms, - a problem torard the solution of which an authoritative decision by proper representatives from English speaking countries would render an important contribution in the interests of medical science.

A thorough understanding and adequate command of anatomical terms con. stitute an important objective in anatomical study. The same is eọally true of dexterity in dissection, independence of observation and the verification of textbook stetements. In the last analysis, however, perhaps the matter of greatest importance is the student's om efforts toward the interpretation and organization of the facts and observations thus acquired. Instructors, cadavers, textbooks, atlases and laboratory manuals are only means to an end. If the student is lacking in this ability or fails to develop it, all of these accessories will be of little avail. A mere memory of anatomical teris and all the minutiae of structure do not in theraselves constitute a working knowledge. It is only as these data become organized in such a way that when confronted with the living body wo can visualize the form, position, relations and functions of its various structures as ccmponent parts of a living working 

machine and at the same time have a ready cumrand of the terms bj which these structures are designated, tho.t we can zegurd cursezves as hating maie a:2y

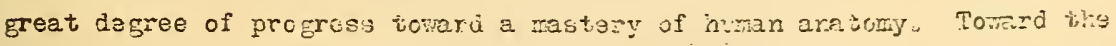
realization of this end the present wcrk is heiessarily oniy cre of pisiy factors. It has jeen uncertaken with a keon appreciation of tre alrios dise couraging character of sume of the perpleving prohlers it involves ard that at best it must represent a boginning which only the cumilative ciats aecuired with more extended experience and criticin ran bring to its greatest perifectin. Its immediate purpeso Mgil, however, be attained if it proves to be 0 i reai utility in the establisiment ồ a basis for a more direct correlictinn uf anatomical torminolegr and stinctare in the practical stuiy of the cadirar and in the presentation of th reane os te

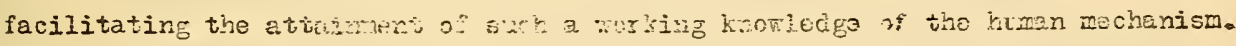

Criticisms, suggestions or Lomiranda cf ervors, a certair rumer of which have not always been sucessfuliy jumirated from the rimeograpia stencils will be greatly welcomed. It has a.lso ioon suggested that should the proposition involved in the present work recomman itself sufficivitily, possicly the cumulative experience and criticism from varicus laboratories migin eveniuaily find expression through some represcitative enatcmical ccrmittee or cumission leading to a more authoritative qriesntetion of the suijest. 


\section{Regional Anatomy}

THE SUPERTOR EXTREMITY

Structures of the back: with reference primarily to etructures in relaticn to the superior extremity.

Surface anatomy -

Regions of the back-1

Fascia, cutaneous nerves and vessels

Muscles, nerves and vessels

Muscles: firgł lazedr

Structures in relation to superior margin of scapulan....

Muscles: second layer

Nerves and vessels .

Anterior thoracic region and axillary fossa.

Surface a natomy -

Pectoral regions -

Anterior thoracic wall: superficial structures

Superficial fascia, cutaneous nerves and blood vessels-.-

Mamma.

Anterior throacic wall: deep fascia and pectoralis major muscle -...-

Axillary fossa and structures subjacent to the pectoralis

major muscle -

Structures in relation to base of axillary fossa-......

Structures exposed by reflection of clavicular part of

pectoralis major muscle -

Structures exposed by reflection of eternocostal part of pectoralis major muscle

Contents of superior part of axillary fossa

Contents of inferior part of axillary fossa

Structures in relation to media? wall of axillary fossa--

Structures in relation to posterior wall of exillary

fossa -

Axillary vessels

Subclavius muscle -

Brachial plexus -

Serratue anterior muscle-_-

Superior extremity: general characteristics _.

Subdivisions ............

Regions of the Superior Extremity

Region of shoulder

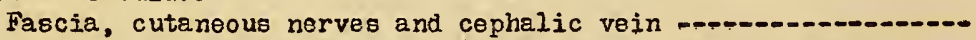

Muscles, nerves, vessels and ligaments of the shoulder-......-

Arm and superficial structures of forearm and dorsum of hand-....-

Surface anatomy of arm and forearmm...

Arm (anterior aspect) and forearm: superficial structures-..--

Cutaneous nerves -

Veins and lymphatics

Arm (anterior aspect): deep structures

Deep fascia

Arteries -

Veins

Page

1

1

2

2

2

2

2 

Nerves

Muscles

CubitaI fossa

Arm (poterior a

ArIl (pjsterior aspect)

Dorsum of hand: superficial structures

Deep fascia and cutaneous narves piercing it ........ 11

Radial artery and nerve a................

Superficial inuscles

Ulnar vesse?s and median nerve

Deep structures on volar aspect of forearm

Wrist and hand: volar aspect

Surface anatomy -

Fascia and cutaneous nerves

Muscles, nerves, vessels and Iigaments
Nerves and vesseis superficial to the Luscles and flexor

tendons of the palm

Ligaments and mucous sheaths of flexor tendons _.............. 13

Lijules

Nerves and vessels internal to the flexor tendons and muscies i3

of the palm

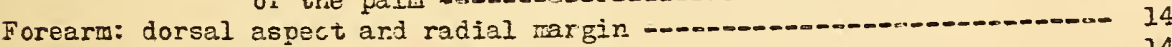

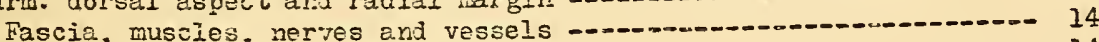

Deep fascia

Superficia] muscles -anamonom 14

Nerves and vessels a nuscos-

Deep miscles - .

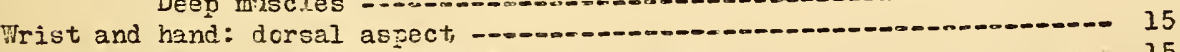

Muscles, nerves and vessels _on........... 15

Vesseis -

iuscies, nerves and ligaments _... 15

Articulations of superior extremity

Sroulder joint-_.n-

Elbow joint -

Joint of the hand -

Radiocarpal articulation

Intercarpal articuiation

Pisiform ariiculaiion

Radioulnar articulation

Carpometacarpa? articulations -

Intermetacarpal articuletions _...

Metacarpophalangeal articulations _......... 16

Articulations of the digits

THORAX AND DEPP STRUCTURES OF THE BACK

General characteristics

Subdivisions of thorax and back -

Surfece a natomy -

General osteological characteristics of the thorax ............ 17

Regions of thorax and back

Thoracic wall: anterior and lateral parts

Intercostal muscles. Iigaments and nerves

Blood-vessels -

Thoracic cavity and viscera

Pleura and pleural cavities .

Lungs 

Surface anatomy -...

Interial structure of lung .......

Root of ling and related structures -

Structures in relation to the right and left rocts-......

Structures within the pulmowry roots

Phrenic rerve and nerves to bhe superificial part of the

cardiac piexus -

Thymus-c-now -

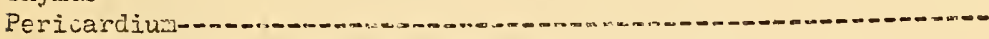

Great veins of the thorax and their trivutaries

Heart and aorta -.....

Surface anatcmy -.................

Nerve and vascular supply wnem...............

Cavities of tho hoart. Pulnoxary vessels

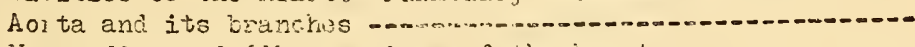

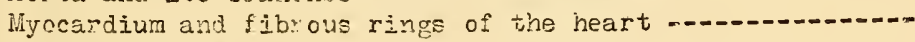

Cardiac plexis -

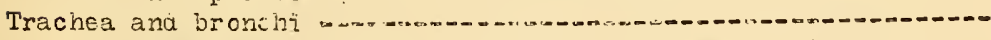

Posterior mediastiral cavity and structures within it -........

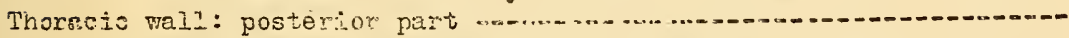

Theracic part of the sympathoti: syetrem -

Structures in reiation to internel surface of posterior

$$
\text { thorecic }
$$

Deep structures of back tom

Posterior serrati muscles and lumbionsal fascia

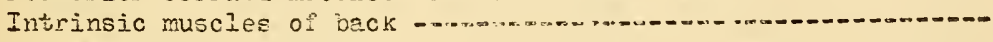

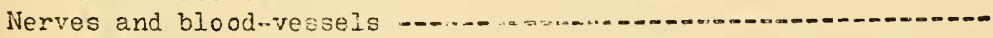

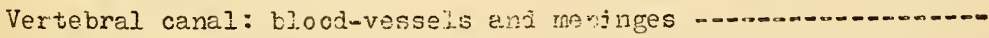

Spinal cord: nerves, blocd-vessels onj surface anatomy .......

Spinal nerves

B. Lou-vessels -

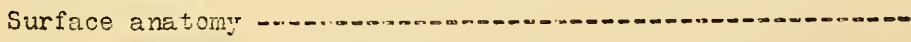

Spinal cord: internal etructure

Gray inatter -

White matter

Articulations of the thorax

Sternocostal articulaticns wan

Costovertebral articuietions -

Capitular articuiations $-n+\infty-\infty$

Costctransverse articulations -

Articulations of the vertebral column

\section{HEAD AND INECX}

Structures in relation to scalp ard temporal region. 30

General characteristics of the cranium

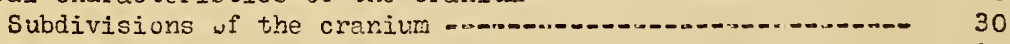

Regions oi the head _........ 30

Scalp and temporal region: sliperficial blood-vessels and

nerves _....................... 30

Frontal region ............... 30

Temporal region an............... 30

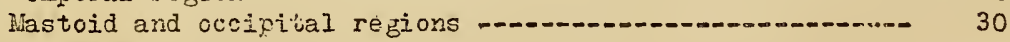

Scalp: deeper structures

Muscles -....... 31

Lymphatics _...

Auricle or external ear 

Intracranial structures in relation to brain and cranial wall .......

Structures exposed by renoval of calvaria

Structures exposed by removal of brain

Roots of cerebral nerves ....... 32

General structural characieristics of exposed base of

cranium and related dura mater

Sinuses of the dura rater

Arteries ..

Hypophysis -

Structires in the lateral and anterior regions of neck ................ 34

Surface aratomy -.....

Regions of the neck _...

Superficial fascia, platysma, reins and cutaneous nerves -.....- 34

Deep cervical fascia and sternucleidorastoid muscle ............ 35

Posterior triangle -

occipital triangle

Supraclavicular triangle -

Supraclavicular part of brachial plexus _................... 36

Muscles in flocr of posterior triangle

Anterior triangle

Submaxillary or digastric triangle -

Carotid triangle -

Iuscular triargle -

Structures in relation to anterior median line of neck ........ 38

Suprahyoid region -...

Infrahyoid region

Muscles of neck: second and third layers

Sternoclavicular articulation

Root of neck - 38

Muscles -

Blood-vessels anỏ Iymphatics _............ 38

Nerves -

Remaining structures at root of neck

Vervical plexus and viscera of neck

Back of head and neck

Ragions of back of head and neck _...

Fascia, superficial nerves and muscles .

ifuscles in relation to back of neck

Deeper blood-vessels and nerves of back of neck _.............. 41

Face and frontal region of head

Surface anatomy -..

Regions of face -... 42

Fascia and parotid gland -

Superficial nerves of face

Superficial blood-vessels of face

Ifuscles of face and sroat of head

Structures in relation to temporal and infratemporal fossae ......... 44

Fascia, muscles and vessels _.............. 44

Niandibular articulation

Nerves -.

MandibuIar canal -

Submaxillary canal -

Superficial structures in submaxillary region ................. 47

Deeper structures in submaxillary region

Structures in relation to deeper regions of neck and base of craniumo- 47

Otic ganglion, tensor veli palatini, stylopharyngeus muscles-a-.- 47

Bl. ood-vessels $--\infty-\ldots-n-\infty-n-m-n-\infty$ 

Sympathetic trunk -

Structures in relation to cervical part of vertebral column, and

posterior part of base of skull

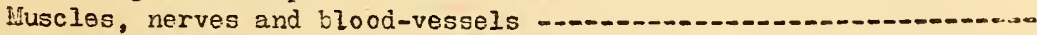

Articulations of cervical vertebrae III-VII _.....

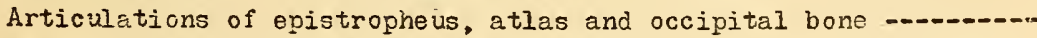

Cervical part of vertebral sanal and spinal corc.

Remaining structures in anterior part of head and neck

Pharyni -..

Nuscies and fascia of pharynx

Cavity of prarynx

Mouth and fauces

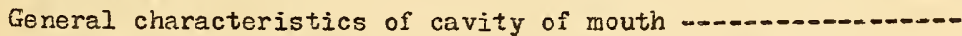

Mucous membrane of mouth

Glands of mouth

Teeth -

Torgue -

Fances -

Soft palate and related structures

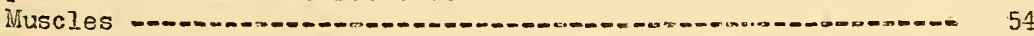

Arteries - 2. 55

Nerves - _.

Auditory tube

Nasal cavity - .

Nasal septum -

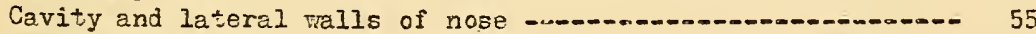

Paranasal sinuses _............ 56

Nerves and vessels in lateral wall of nasal cavity ......... 56

Nasal cartilages -

Larynx -

Gavity of larynx

Laryngeal muscles, hyothyreoid and elastic membrane -....... 57

Laryngeal nerves and vessels

Laryngeal cartilages and ligaments _... 58

Tongue -._. 59

General characteristics and surface anatomy .

Muscles of tongue

Nerves and vessels of the tongue $\ldots$

Structures in middle cranial fosia

Eyelids and lacrinal apparatus _... 61

Eyelids -

Lacrimal apparatus: - 61

Structures in relation to orbit 61

Structures in superior part of orbit and fascia of eyeball ...... 61

Optic nerve, nasociliary nerve and ciliary ganglion ............

Blood-vessels of orbit _.....

Remeining structures of orbit

Structures in carotid and infraorbital canais and pterygopalatine fossa 63

Carotid canal _.

Maxillary nerve and infraorbital canal _........ 63

Sphenopalatine ganglion

Internal maxillary artery _... 64

Auditory apparatus: external and middle ear

Walls of tympanic cavity

Auditory ossicles, articulations, ligaments and muscles ......... 65

External acoustic meatus ..... 66

Intraosseous course of facial, intermediate and acoustic nerves ...... 66 

Brain: General characteristics, meninges, blood vessels and cerebral nerves -...

Larger subdivisions of brain

Meninges and blood vessels of brain

lieninges -..........

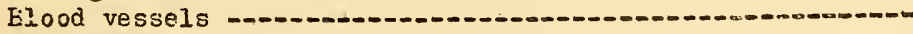

Base of brain and cerebral nerves

Base of brain .

Cerebral nerves -.

Brain: Surface anatomy of rhombencephal on and mesencephalon m......

Rhombencephal on

Wedulla oblongata

Pons -..-con-

Isthmus of rhombencephalon

Cerebellum -

Fourth ventricis .

Flocr of fourth ventricle

Roof of fourth ventricle

Mesencephal on -

Brain: Surface anatomy of prosencephalon

General subdivisions of prosencephalon

Telencephalon -

Pallium: general characteristics

Lobes of cerebrum -

Medial surface of hemisphere

Rhinencephalor - - -

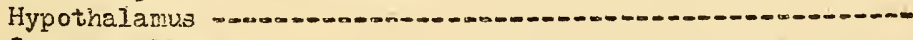

Corpus cajlusum -

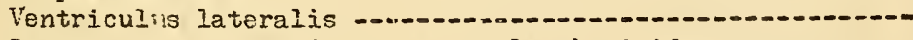

Septum peilucidum, fornix and tela chorioidea $\ldots \ldots \ldots$

Thal amencephal on

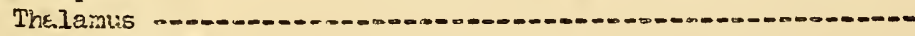

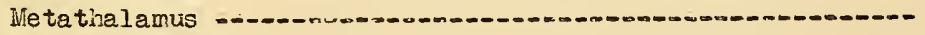

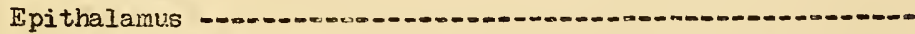

Ventricuzus tertius -

Brain: Sections through brain $\ldots \ldots \ldots \ldots \ldots$

Structures in sections of medulla oblongata

Structures in sections of pens -

Structures in sections of cerebell um

Structures in sections of rhombenciphalic isthmus and

mesencephalon

Sections of isthmus rhombencephali

Sections of pedunculus cerebri

In sections of corpora quadrigemina

Structures in sections through prosencephalon

Sections of hypothalemus -

Sections of thalamencephalon

Sections of telencephalon

Organ of Vision

Cptic nerve

Bulbus oculi

Tunica fíbrosa oculi -

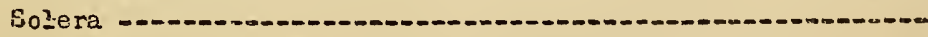

Cornea -

Tunica vasculose oculi

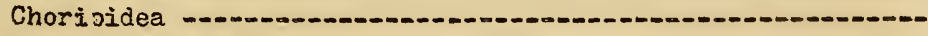

Corpus ciliare

Page

67

67

67

67

68

68

613

69

69

69

70

70

70

70

71

71

71

71

71

71

72

72

72

73

74

74

74

74

75

76

76

76

76

77

77

77

77 

Iris Page

Ciliary serves and vessels

Pigment layer - 80

Retina -......

Vitreous body

Zonula ciliaris _.......... 81

Crystalline lens ..........

Chambers of eyeball t...

\section{ABDOIEN AND PELVIS}

General characteristics -

Subdivisions of abdomen and pelvis _.......... 82

Surface anaiomy -..-

Regions o-

Perineal region

Surface anatomy -

Perineal region in general _...

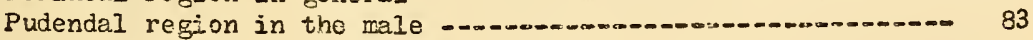

Pudendal region in the feraie - 83

Urogenital region: structures external to urogenital diaphragm-s... 83

In the male $\ldots 3$

In the female .

Urogenital diaphragm

Inferior fascit of the urogenital diaphragm $\ldots$

Structures in the urogenital diaphragm in the male .m...... 85

Structures in the urogenital diaphragm in the ferele ....... 85

Anal region -....... 85

Anterior abdominal wall

Fascia, cutaneous nerves and vessels _............ $8 i$

Deeper structures of anterior abdominal wall

liuscles and related siructures ....... 86

Internal surface of anterior abdominal wall _........ 87

Inguinal canal, scrotum spermatic cord and testis _............ 88

Inguinal canal .... 88

Scrotum and spermatic cord -

Testis -

Abdominal cavity, peritoneum and viscerq ..... 89

Abdominal cavity and peritoneum - 89

General characteristics of abdominal cavity, viscera and

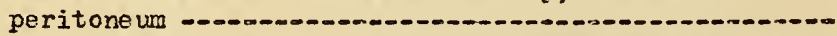

Peritoneal folds and fossa in relation to small and large intestire

Peritoneal ligaments in relation to liver, stomach and spleen 89

Omental bursa .......... 50

Relations of pelvic peritoneum

Peritoneal relations in general. $\ldots$

Mesenteric blood-vessels, nerves and lymptatics ................. 90

Mesenterial small intestine and the large intestine ............. 91

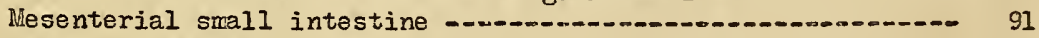

Large intestine -

Structures in relation to the wall of the omental bursa $\ldots . . . . . .92$

Biliary ducts and vessels in the lesser omentum _......... 92

Remaining vessels in relation to walls of cmental bursa-..... 92 

Duodenum and pancreas

Duodenum -.0.-

Pancreas -

Stomach and spleen

Stomach

Spleen -

Sympathetic plexuses in relation to coeliac ganglion and ceoliac

Liver plexus

Suprarenal gland, kidney and ureter

Suprarenal gland, - ................

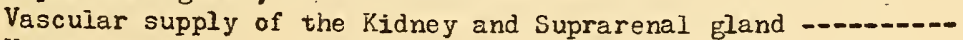
Kidney -.........

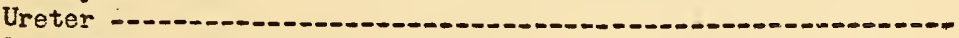

Diaphragm -..-

Structures in relation to the posterior abdominal wall

Blood-vessels and lymphatics

Arteries - -

Veirs and lymphatics -

Fascia and muscles of posterior abdominal wall

Nerves of the posterior abdominal wall

Osteology - -

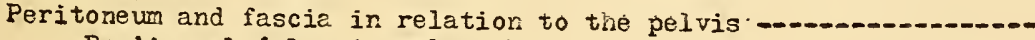

Puritureal fOI 10 id Fuis Fejvo

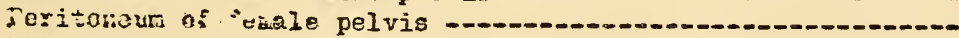

Fascie -

Pelvic viscera -

In the male pelvis

In the female pelvis

Pelvic blood vessels (male and female)

Arteries -

Veizas -

Pelvic muscles and nerves -

Pelvic articulations

\section{THE INFERIOR EXTREMTTY}

General characteristics of inferior extremity - 105

Subdivisions -

Regions -

Gluteal region

Surface anatomy -

Fascia and cutaneous nerves

Glutaeus maximus muscle

Structures exposed by reflection of glutaeus maximus muscle

istructures distal to the piriformis muscle

Structures proxinal and lateral to the piriformis muscle-.-.- 107
Structures exposed by reflection of glueaeus minimus muscle $-\ldots-\ldots$

Popliteal space

Surface a natomy

Fascia, superficial nerves and vessels

Dopliteal space: large nerves and vessels

Popliteal space: medial and lateral boundaries $\ldots$

Contents of popliteal space

Nerves

Blood-vessels and lymphatics $\ldots 8$ 

Floor of popliteal space

Posterior part of thigh

Fascia and cutaneous nerves

Hiscles -...

Nerves and blood-vessels

Anterior part of thigh 109

Surface anatomy

Recions in relation to anterior aspect of thigh ............... 110

Fascia, superficial vessels, lymphatics and cutane rus nerves ...- 110

Superficial fascia, blood-vessels and lymphatics ......... 110

Fossa ovalis - 110

Cutaneous nerves, superficial praepate:zar bursae $\ldots \ldots \ldots \ldots$

Deep fascia and related ligaments ........................ 111

Femoral sheath -....... 111

Femoral trigone and its contents

Adductor cainal and its contents

Muscles of the front of thigh

Hedial side of thigh

Muscles, nerves and vesséls ...

iijp joint ............. 114

Structures in relation to hip joint

Leg and foot ...........

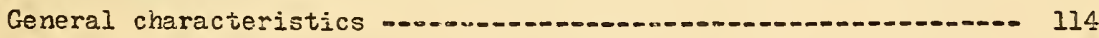

Subdivisions -...- 114

Surface anatony -.

Regions -.

Anterior region of leg and dorsur of foot

Superficial fascia, cutaneous nerves and vessels ........... 115

Deep fascia -

Muscles in anterior rtgion of $1 \mathrm{eg} \ldots \ldots \ldots \ldots$

Arteries . .

lierves

iuvescles of dorsun of foot

Lateral or percneal region of leg

Deep fascia and riscles n._.

Nerves -

ihedial region of $10 \mathrm{~g}$

Posterior region of leg and heel _............ 117

Fascia, superficial vessels and cutaneous nerves .......... 117

Wuscles: superficial group

Iuscles: deep group -

Arteries

Nerves -

Laciniate ligament _...

Plantar region ô̂ foot _...

Fascia and superficial veins -

Miuscles: superficial layer -

Plantar arteries -

Plantar nerves -...

Wuscles: second layer of muscles and tendons -

Miuscles: third layer

Plentar arch and deep division of plartar nerve ........ 120

Interosseous muscies and deep tendors .......... 120 

Articulations of $\mathrm{leg}$ and foot Knee joint ... Ankle joint

Tibiofibular joints _.......... 121

Intertarsal articulations

Tarsometatarsal articulations

Intermetatarsal articulations _.

Metatarsophalangeal articulations -

Articulations of toes _.

Part Two

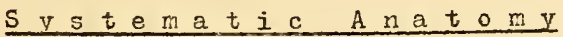

GEIERAI ANATONICAL TERMS.

Terms Indicating the Position and Direction of Parts of the Body .... 1

Terms Relating to the Body in Gereral

Tens Relating to the Extremities

General Anatomical Terms _.

\section{PARTS OF THE HULAN BCDY.}

Head -

Craniun -

Face -

Eye -

Nise -

Mouth

Neck

Trunk -

Thorax

Back -

Abdomen -

Palvis -

Superinr Extrenities -..

Inferior Extremities -

\section{OSTEOLOGY}

Vertebral Column, or Spine 6

Atlas -

Epistropheus -

Sacrum-_-

Coccyx -

Thorax

Rihs -

Sternum-_- 7

Thorax (general characteristics) 7

Banes of the Cranium

Basilar Bone -

Occipital Bone -

Sphenoid Bone -

Temporal Bone 

Parietal Bone -1.0. D?g:

Fr:

Eithmoid Bone -

Inferior nasal concha

Lavrinal Bone -

Niasa] Bene -..--

Vomer -

Eones of the Face

Miaxilia

Fả̇ite Bone - -

Zy

liandivle -

Hyoid Eone -

Craniure

Sutures of the Craniux -

Synchondroses of the Cranium -

Bones of the superior Extremity -

Shoulder gìñìe -w-

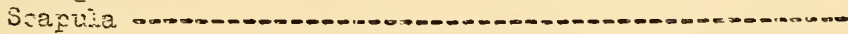

Ciatricie mw-

Skejetrr cf free upper Extremity -

HLmex lis

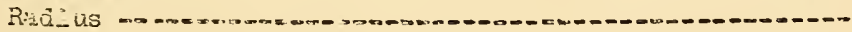

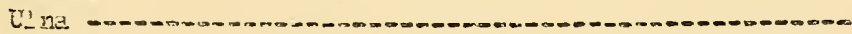

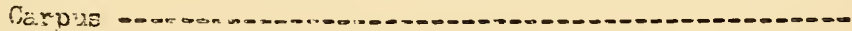

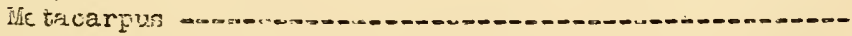

Fhalanges s-mes-m-n.

Bones of the inferiv: Exuremity -wo-m-nom

Pelvic gïrd.. -

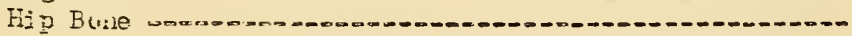

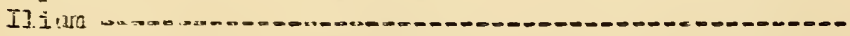

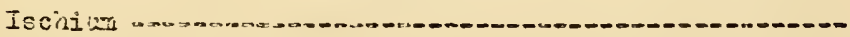

Pujis +...6-

Pelvis - -

Skeleton of free lower Jxtremity

Femur - - - - -

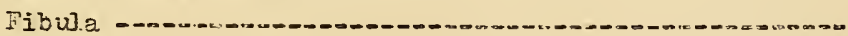

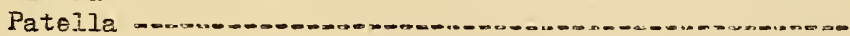

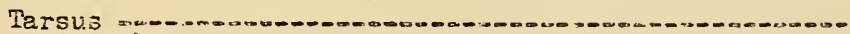

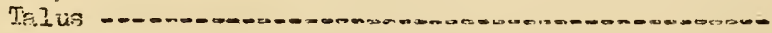

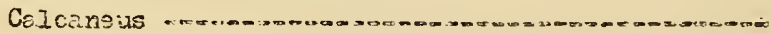

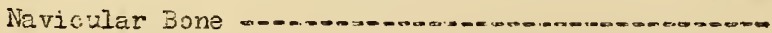

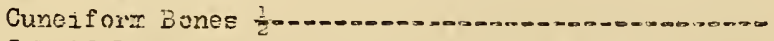

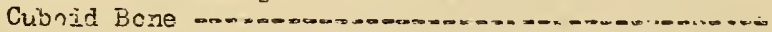

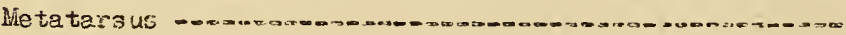

Phalanges --1_-

\section{EYMTESTOTOCY}

Ligaments of the Verte?ra? Colwon and Cranilum ................... 18

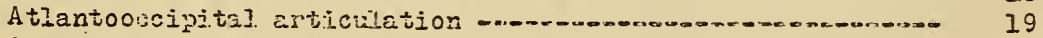

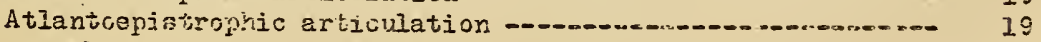

Costovertebrai artivilations .

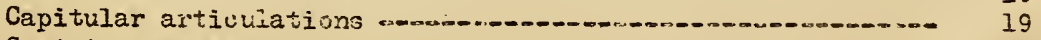

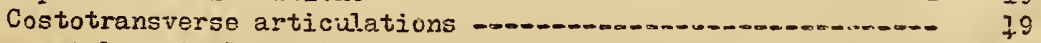



Mandibular articulation

Ligaments of the shoulder girdle

Acromicalavicular articulation

Sternoclavicular articulation

Shnulderejoint -

Elbov-joint - jo-

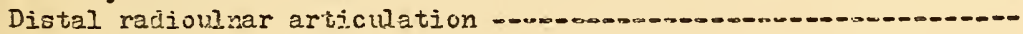

Articulation of the hand -

Arículation of the pisiform bone

Carpometacaxpal articulations -

Carpumetacarpal articulation of the thumb

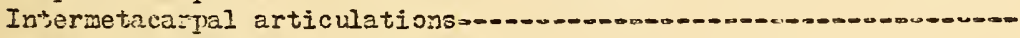

Metacarpophilaingeal articulations -

Articulations of the fingers

Ligaments of the pelvic Girdle

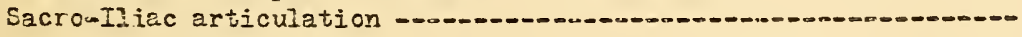

Symphysis of Pubic Bones -and

Hip-joint -..- jo

Knog- ivi is-. - . - -

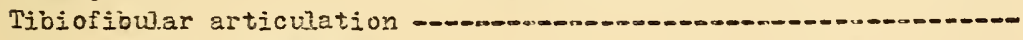

Tibiofibular Syrdesnosis

Articuiations of the Foot -..........

Talocrural articulation (Ankle joirt)

Intertirsal articulations -.

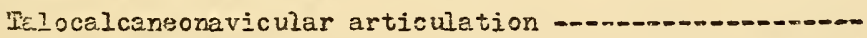

Tci joalumean arijeulaition

Clicprrt's Transverse Articulation of the Tarsus ........

Teiunavicular articulation

Calcarsocuboid articulation -..........

Cuneonavicular articulation -....

Interosseous Ligaments of Tarsus -

Dorsal Ligaments of Tersus -

Plantar isigarents of Ra.eus -

Tarsonetatarsal artivitations -

Intermetataras? arjiculations -

Metatarsopha?angeal at'ticulations -

Articulations of the Foes

Page

19

19

19

19

19

\section{MYOLOGY OR MUSCULATURE}

Muscles of Back

Muscles of the Heac

Muscles of the Hyoid Bone

Rifuscles of the iNeck

Muscles of the Thorex

Muscles of the Abdomen

Coccygeal ifuscles _._-

Muscles of the superior Extremity

Muscles of the Inferior Extremity $\ldots \ldots$ 



\section{BURSAE AND MUCOUS SHEATTHS}

\section{SPLANCHNOT,OCY}

\section{Digestive System}

Oral cavity -and 30

Oral wucous metnbrane

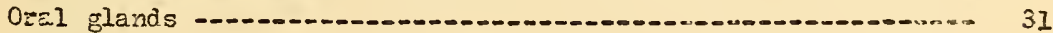

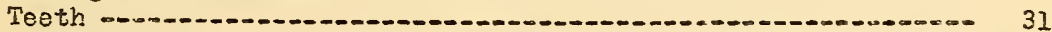

Tongue -

Fauces -o.n-

Miuscles of the palate and fauces $\ldots \ldots \ldots \ldots$

Pharynx -

Digestive tube

Oesophagus -

Stomach -

Small intestine -

Large intestine ................... 33

Rectum -

Pancreas _...

Liver _

Spleen -

\section{Respiratory System}

Nasal Cavity - .

External Inose -

Larynx - .

Laryngeal Muscles _...................

Laryngeal Cavity -

Trachea and Bronchi _.

Lung

Thoracic Cavity

Thyre

Thyreoid Gland -

Glonus caroticum - .

Thyymus -

\section{Urogonital System}

Uropoietic Organs

Kidney -

Renal Arteries -

Renal Veins -

Ureter

Jrinary Bladder _...

Suprarenal Gland -

Genital or reproduciive Organs $\ldots \ldots \ldots$

lkale Genital Organs $\ldots . . .639$

Testis ano 39

Seminel Vesicle

Spermatic Cord and tunics of the Testis and spermatic Cord -.. 40

Prostrate -.... 40

Bulbo-uretihra? Gland -

External Genital Structures

Penis 

iliale Uretinra .....

Scrotum

Female Cenital Organs

Uterine Tube -

Uterus -

Vagina -

Epoophoron -

Paro ophoror -

External Gerital Parts

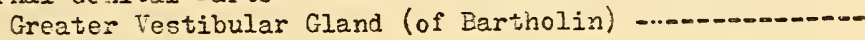

Cistoris -...-

Feraie Ürethra

Perine un -

Peritoneum -

Page

41

41

41

41

41

41

42

42

42

42

42

42

42

43

43

\section{ANGIOLOGY}

Heart -

Right Atrium -

Right Ventricule -

Left Atrium -

Left Ventricle

Arteries -

Pulmonary Artery -

Aorta =

Innominate arteiry -

Common Carctid Artery -

Ëxterial Carotid Artery -

Superior Thyreoid Artery _..... 45

Ascending Pharyngeal Artery .... 47

Lingual Artery _...

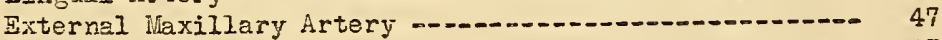

Sternocleidomastoid Artery - 47

Occipital Ártery -

Posterior Auricular Artery -

Superficial Temporal Artery -...-. 47

Internal Maxillary Artery _..- 47

Internal Carotid Artery

Ophthalmic Artery

Cerebral Arteries - $4: 3$

Subclavian Artery -

Vertebral Artery -

Basilar Arter

Internal ilamriary Artery

Thyreocervical Trunk

Inferior Thyreoid Artery -.... 48

Ascending Cervical Artery _. 48

Transverse Scapular Artery

Costocervical Trunk

Transverse Cervica? Artery - 48

Axillary Artery -

Highest Thoracid Artery

Thoraco acrominal Artery

Lateral thoracic Artery

Subscapular Artery _. 49 

Anterior Circumflex humeral Artery

Posterior Circumilex humeral Artery

Brachial Artery -...

Prof unda Brachii Artery

Superior Ulnar Collateral Artery

Inferior Ulnar Collateral frtery

Radial Artery -.....

Ul nar Artery

Thoracic Aorta

Intercostal Arteries -

Abdominal Aorta

Inferior Phrenic Artery

Lumbar Arteries _.

Wifidle Sacral Artery -

Coeliac Artery

Superior Mesenteric Artery _..

Inferior Mesenteric Artery

Middle Suprarenal Artery

Renal Artery -.....

Internal Spermatic Artery

Testicular Artery

Ovarian Arte5y -......

Common Iliac Artery

Hypogastric Artery .....

Iliol umbar Artery

Lateral Sacral Artery

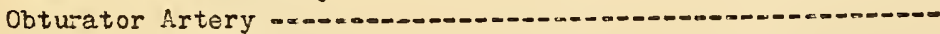

Euperior GIuteal Artery

Inferior Gluieal Artery

Umbilical Artery

Inferior Vesical Artery

Deferential Artery

Uterine Artery -

Middle Hemorrhoidal Artery

Internal Pudendal Artery

External Iliac Artery

Inferior Epigastric Artery

Deep Circumiles _.

Femoral Artery -

Popliteal Artery

Anterior Tibial Artery

Posterior Tibial Artery

Veins

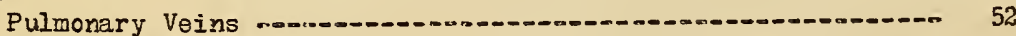

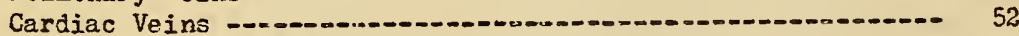

Superior Vena Cava

Right and Left Innominate Veins -........ 52

Internal Jugular Vein ... 52

Sinuses of the Dura liater

Cerebral Veins ... 53

Superior Opnthalmic Vein _... 53

Common Facial Vein

Anterior Facial Vein

Posterior Facial Vein

External Jugular Vein

Subclavian Vein 

Axillary Vein

Azygos Vein -

Inferior Vena Cava -

Portal Vein ... 55

Common Iilac Vein

Hypogast-ic Vein

Exiernal Iliac Veins -...

Lymphatic Systein -....

Lymphatic Vessels _... 56

Thoracic Duat -

Lymph Glands - 56

Lymphatic Plexuses -

\section{NEUROLOGY}

Central nervous system.

Spinal cord -

Sections of spinal cord

Encephalon (orain

Rhombencephal on -..... 59

Myelencephal on (medulla oblongata)

Sections of méduila oblongata

lietencephal on (hind-brain) _. 60

Pons _...................... 60

Sections of pons - 60

Cerebellum

Sections of cerebellum _........ 61

Isthmus of Rhombencephal on _... 61

Sections of Isthrmus ..... 61

Cerebrum -.... 61

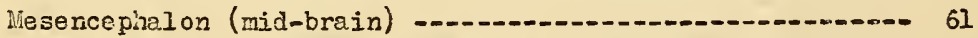

Sectione of cerebral peduncle _......................... 61

Sections of quadrigeminal bodies ................... 62

Prosencephalon (fore-brain) _.

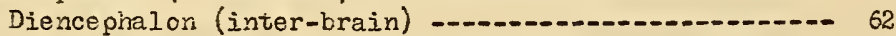

Hypothalamus

Sections of hypothalamus .............. 62

The lamencephal on - 62

Thalamus -...... 62

ive tathalanus -... 62

Epithalamus f-....... 62

Sections of thalamencephalon ........... 62

Telencephal on (endwbrain) _....... 63

Hemisphere -........ 63

Pallium -

liedial surface of hemisphere -........... 63

Corpus callosum -....... 64

Fornix -

Septuw pellucidum - 64

Lateral ventricle

Rhinencephalon

Sections of telencephalon

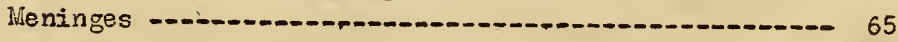





\section{Peripheral nozvous system.}

Cerebral nerves

01 \{actory nerves -

Optic Nerve

Oculomotor Nerive

Trochlear Nerve

Trigeminal Nerve

Ophthalmic Nerve

Maxillary Nerve

liandibular Nerve _... 67

Aiducent Nerve

Facial Nerve -

Accustic Nerve

Glossopharyngeal iverve

Vagus iverve -

Accessory iTerve - 68

Hypoglassal Nerve

Spinal Nerves

Cervical Nerves

Brachial Plexus - 69

Median Nerve -

Un nar Nerve

Radial Vierve L-

Thoracic Nerves - 69

Lumbar, Sacral, and Coccygeal Nerves

Lumbosacral Plexus _. 70

Lumbar Plexus _. 70

Ijliohypogastric Nerve

Ilioinginal iverve

Genitofemoral _...... 70

Lateral femoral cutaneous Nerve _....... 70

Obturator Nerve

Femoral Nerve - 70

Sadral plexus - 70

Sciatic Nerve -..6- 70

Pudendal plexus

Coccygeal Nerve -

\section{Sympatinetic Nervous System.}

Cephalic and cervical parts of the sympathetic system

Thoracic part of the sympathetic system

Abdominal and pelvic parts of the sympathetic system $\ldots \ldots \ldots \ldots \ldots$

\section{SENSE ORCANS AND COMION INTEGUNENT.}

Organ of Vision

Eye -

Optic Nervo -

Eyeball -

Fibrous Tunic of Eye - 73

Sclera -

Cornea -

Vascular Coat of Eye 

Chorioid -

Page

Ciliary

Iris -..-

Pj.gment layer .........

Retina -

Anterior Chanbe: of the Eye

Posterior Chamber of the Eye

Vitreous Body -

Civstalline

73

74

74

74

74

74

Ciliary Zonule -

Accessory Organs of the Eye

Eve Muscles, ofbital Fasciae

Eyebrow-_._-...

Eyelids -

Conjunctive

Iacrimal Apparatus -......

Organ of Hearing

Interral Ear -

Membraneous Labyrinth -

Osseous Labyrinth

Ves'tibule -

Cochlea -....

Enternal Acoustic Meatus -

Tympanic Cavity

Tympanic dembrane -

Auditory Ossicles .

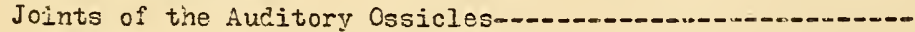

Ligaments of the Auditory Ossicles -

Muscles of the Auditory Ossicles

Ty:panic Ifucous Coat -....

Auditory or Tustachian Tube

External. Acoustic Neatus -

External Ear -

Organ of Smeil ....

Crgan of Taste ......

Common Integument

Skin

Epiderris -

Cפrium -

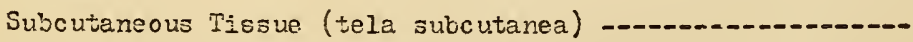

Terminel Corguscles of Nerves -.....

Hair

Corninel Corguscles of Nerves -

Nails -on

Ilands of the Skin

Glomi forn Glands -

Sebaceous Glands -

Breast 

Part One

REGIONALA ANAOMI

- - - . - . - . - . - 


Rogional Anatorny 1

SUPERTOR EXTREMITY

\section{Structures of the Back: with reference primarily to}

\section{Structures in Relation to the Superior Extremity.}

\section{Surface anatomy}

Structures which ray be identified by inspection and palpation. SPINOUS FROCESEES $-6: 37$

VERTEBRA PROMIIINS $-6: 38$

MEDIAL ANGEE OF THE SCAPULA-13:52

INFERIOP ANCJE OF TIE SCAPULA-13:50

SPINE OF TIE SCA-UIA-13:42

ACRONION $-13: 45$

ILIAC CREST $-15: 18$

In conformity with the Basle Anatomical Nomenclature (BNA) all brackets relating to anatomical terms are used in the following sense:

I. Oval brackets () inciicate variations (varietates anatomicae).

II. Angular brackets \& contain explanatory additions, among which are

included double names and personal nanies.

III. One affixed asterjsk $x$ is lised to indicate ontogenetic expressions, (e.g. MEIBRANAE, DECIDUA ${ }^{X}-43: 5$, VNA UABILICALIS ${ }^{x}-55: 34$, etc.).

IV. Two affixed asterislis $x x$ are used in a few instances to indicate structures which may be either especially difficult to demonstrate by ordinary methods of dissection cr appear relatively of secondary importance.

The numerals affixed to each term in the regional anatomy (Part I) cite the page and number of the same term in its systematic position in the outline of systematic anatomy (Part II). In connection vith these cross references, it will be observed that the terms in Part I are anglicized in some instances and given in their Latin form in other instances, whereas in Part II the terms appear exclusively in Latin. In the latter case, the term corresponds with the original $\mathrm{BN}$ A; in the former case the term has been used in the form which appears to coincide with the usage ccmon to the majority of standard American and English anatomical terts, but it is to be recognized that as yet there is no authoritative English list based on the B N A and that for the present decisions upon this point are necessarily largely dependent upon the individual preferences of author and student. (See also discussion in the Preface).

In general the subject matter is arranged with a view to practical utility. To this end the terms in Part I are grouped primarily in the seyuence in which the correspording structures may be exposed and ooserved in actual dissection. The text in small type gives ccncise statenents of the more impcrtant incisions and dissections necessarily involved in an adequate demonstration of these structures as they are encountered in any given region. The pago arrangement of the terms in general is such as to leave a certain amount of space available for marginal notes or references. 

2. Regions of the back

MEDIAN REGION OF THE BACK-83:24

INTERSCAPUIAR FAGION- 83:25

SCAPULAR RE:GION $=83: 26$

SUPRASCAPUIAAR REGION-83:27

IINFRASCAPULAR REGION-83:28

LUMBAR REGION-83:29

REGION OF THE HIPm $83: 30$

SECRAI, REGION-23:31

GLUTEAL REGION- $83: 32$

PERINEAL REGION-83:33

3. Fascia, cutaneous nerves and vessels

Shin incisions: a) in the midline from the vertebra prominens to the tip of the coccyx; b) from the tip of the coccyx to the posterior superior iliac spine, thence along the iliac crest to within about $25 \mathrm{~cm}$, of the anterior superior iliac spind; (i) from the vertebia prominens to the medial margin of the acromion; d) from the spinous process of the first lumbar vertebra to the lateral marcin of the acromion. SUPERFICIAL THSC:A-23:36

MEDIAL CUTANEOUS PAII OF POSTERIOR RAIII OF THORACIC NERVES-69:77

LATERAL CUTANEOUS RAIII OF POSTIRTOR RAIII OF THORACIC NERVES-69:76 POSTERIOR PAIII OF LATERAL CUTANEOUS RANI OF INTERCOSTAL NERVES$70: 4$

MEDIAL RAMI OF POSTERIOR RAMI OF LUMBAR, SACRAL AND COCCYGEAL NERVES-70:13, 19

LATERAL RANI OF POSTERIOR RANI OF LUMBAR INRVES-70:14

MEDIAL CUTANEOUS RAMI OF POSTERIOR RAMI OF INTERCOSTAL ARTERIES$49: 63$

DORSAL RAMI OF LURBAR ARTEKIES-50:10

PUSTEEIOR RANI OF LATERAL CUTANEOUS RAMI OF ANTERIOR RAMI OF INTERCOSTAL ARTERIES $-49: 68$

4. Muscles, nerves and vessels

a. inuscles: first layer

Exposed by removing both superficial and deep layers of fascia. TRAPEZ.IUS IUUSCI,E-23:15

IATISSIIUSS DORSI MUSCIE-23:17 Not including its insertion. TRIGONURI IJUMBALE-2 5:48

b. Structures in relstion to the superion margin of the scapula Demonstrated by detaching the thoracic part of the trapezius muscle at its origin, separating it from the cervical part of the muscle by a transverse incision at the level of the vertebra prominens, and reflecting the thcracic portion toward its insertion, exposing at the same time the external ramus of the accessory nerve-63:59, and the muscular rami from the third and fourth cervical nerves supplying it. INFERIOR BELLY OF THE ONOHYOID INUSCLE-24:59

SUPRASCAPUI,AR NERVE $-69: 31$.

TRANSVERSE SCAPUIAR A.RIERY-48:60

SUPERIOR TRANSVERSE SCAPULAR LIGAMENT-19:43 

c. Muscles: second la*er

RHONBOIUEUS THOR TUETE-23:18

RHONBOIDEUS WINOA MUSUTE-23:18

LEVATOR SUAPUIAE MUSCLE-23:20

Insertion only.

The descending ramus of the transverse cervical artery-48:69 may be observec in the interval between the rhomboideus minor and the levator scapulae muscles.

d. Nerves and vessuls

The followirg ne'ves and artery may be exposed by detaching the levator scapulae muscle at its insertion and the rhomboid muscles at their origins, and reflecting the latter muscles toward treir insertions.

DORSFL SCAPTIAR IERTE-69:27

DESCEINDTNG FAINUS OF THE TRANSVERSE CRRICAL ARTERY.=48:69

The foliowirg structures may be demonstrated by detacining the latissimus dorsi muscle at its origin and reflecting the muscle toward j.ts insertion.

TIORACO2ORJAT NERVE-69:33 Termination only.

THORACODORSAL ARTERY-49:10 Iermination only.

\section{Anterior ruraric region ang a vilary fossa.}

1. Surface anatomy

Structuces mhich may be identified by inspection anà palpation. CLAVICLE . 23:59

STERNAI, EYTREMITY $=3: C 0$

ACRONIAL, EXTRENITY-13:63

STERIUN-7: $\leq 6$

MANLBPIU: $=7: 47$

JUGULHR NOTCH-7:54

BODY OF STERNUH $-7: 50$

ANGI CI STEFNU: $-7: 48$

$X=P H O I N$ PROCESS $-7: 52$

RIBS I-XII-7:28

COSTAL CARTILAGES-7:32

CORACOID PROCESS OF THE SCAPULA-13:58

MAMMA- $4: 50,80: 5$

PAPILLA NANUAE-80:6

CORPUS HANMAEE-80:7

ARTOLA MAMUAE-80:14

ACCESSORY MANMAI- $-80: 18$

AXILIA- $5: 10$

ANTERIOR AXIIJARY FOLD-5:11

POSTERIOR AXILIARY FOLD-5:12

HURIRUS $-13: 67$

2. Pectoral romions-83:2

ANTERIOR PECTORAL REGIOH-83:3

STIRNAI, RECION-83:4

CLAVICULAR REGION-33:5

INFPACIAVICUTAR RUCION-83:6

DELTOIDEOPECTORAI TRIAIIGL $-83: 7$

MARIIARY REGION-83:8

INIRAIIAAMARY REGIOI-83:9 



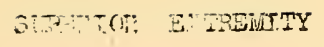

LATERAI, PECTORAL REGION-83:10

AXILI ARY REGION $93: 22$

AX:-TLRY FOSSA-83;12

LATERAL, COSTAL REGION-83:13

3. Anterior thoracic wali: superficial structures

a. Suverficial fascia, cutaneous nerves and blood vessels

Skin incisions: a) longitudinally from the xiphoid process transversely arourd to the back; b) from the jugular notch lateraliy, along the slavicle, to the tip of the acromion; c) from the xiphoid proness obliquely upward and laterally along the anterinr axillary fold to the arm, encircling the areola mamae and leaving it in sivis,

SUPERFTC:A FASCIA-23:36

PIATYSMA MSC E-24:54

SUPRACLA YTCTILAR NERVES-69: $: 7$

ANLFIOR SUPEACTAVICUEAR NERVES-69:18

IIIDLT I' SITERACIAVICUTAR NERVES-69:19

POSTYZTOR SUPRACIAVICUIAF NERVES $-69: 20$

ANTERIOR CUTA LOTS RAII OF INTERCOSTAL NRRES-70:8

MEIIAL MAMMLIRY RA.MT $=70: 9$

AINTERICR RAII OF IATERH CUTAEOIE PANI OF INTERCOSTAL NERVES IV to $V \bar{I}=70: 5$

POSTERIOR RANI ON LATERAL CUTANGGUS RAMI OF INTERCOSTAL NERVES IV to $\mathrm{VI}=70: 4$

LATERAL WAMNARY PAMI OF LATERAL CUMANBOUS RAIII OF INTERCOSTAL LERVES-70:6

PERFORATING RANI OF INTERIAI IFAMAARY ARTERY $-48: 40-43$

LATERAI, CITANEOUS RANI OF ANIERIOR FANI CF INTERCOSTAL ARTERIES IV to VI $=49: 0^{7} 7$

TRIBUTARIES OF INTERNAJ, GAMAARY VEIN

b. Wamma $-80: 5=18$

4. Anterior thoracic all! deep fascia and pectoralis ma jor musclex PECTORAL FASCIA-25:22

(STERNALIS MUSCLE) $-24: 73$

PECTORALIS MFJOR MUSCIE-24:74-77 Not including its insertion. Expssed by romoving the pectoral fascia but leaving intact the axiliary fascia.

5. Axillary fossa, and structures subjacent to the pectnralis major muscle

a. itructures in relation to the base of the axillany fossa

AXILIARY FASCIA-26:40

INEERCOSTOBEACHIIL NERVES-70:7

THORA CODORSAL INERE-69:33

THORACODORSAL ARTLRY $-49: 10$

LATERAL THORACIC AFTERY -49:7

LONG THORAIIC NERVE-69:28

ANILIARY LDIP: GJAANDS-56:45 

b. Structures exposed by the reflection of the clavicular part of ine pectora?is ma jor mus: 3

Demorstratod by detaching the clavicular part of the pectoralis major muscle ai its origin and reflecting it toward its insertion. CORACOCLAVICULAR FASCIA-25:23

THORACOAGROMIIT, ARTERY-49:2

ACROMCAI, RAMTS $-49: 3$

ACROHIAT, NETTORK $-49: 4$

IETSOTD RAMUS-49:5

PECIORAL, BAID- $49: 6$

THORACOACROEIAT, VEIN-54:27

CEPHAIII VETN-54:37

ANTERIOR THORACIC NERVES-69:29

c. Strucuunes exposed by the reflection of the sternocostal part of uho lorjalis major muscie

Demcsstrated by dividing the sternocostal part of the pectoralis major muscie inidray betvreen its origin and insertion and reflecting the two parts medially and laterally respectively. COPACOCTAVICUT:R. FASGIA-25:23

PLCTORALIS MUER MUSCLE $\rightarrow 24: 78$

d. Contents of the zuperior paz of the axillary fossa

Exposed by removing the purtion of the coracoclavicular fascia extending between the clavicle and the superior margin of the pectoralis minor musclo.

AXILIARY ARTERY $-48: 70$ Its first part.

AXILIAARY VEINS-54:29

BRACHIAL PLEXJE-69:24

IEDIAI CURD -69:39

LATERAI, CORD- $69: 38$

POSTERIOR CORD-69:40

LYMPH GLANDS

e. Contents of the inferior part of the axiliarv fosse

Exposed by removing the fascia and fai inferior to the pectoralis minor muscle.

AXILIARY ARTERY $=48: 70$ Its third pari.

MEDTAN NRRVE-69:48

RIUSCULOCUIANEOUS NERVE-69:4I

HEDIAL ANEIBRACHTAJ, CUIANEOUS NERVE-69:45

AXILIARY VEIN $-54: 29$

PRDIAL BRACIIAL CUTANEOUS NERVE-69:44

ULNAR IERVE-69:55

i. Structures in relation to the medial mall of the axillary fosse INTERCOSTCBRACHIAT, NERVES-70:7

LONG THCRACIC NERVE-69:28

IATERAL THORACIC ARTERY $-49: 7$

PECTORAL LYMPH GLANDS $-56: 47$

g. Structures in relation t,o the posterior wall of the axillary fossa THOPACODORSAL NER $\sqrt{\mathrm{E}}-59: 33$

SUBSCAPULAR ARTERY-49:9 

SUBSCAPULAE, :FR?

SUBSCAPULAR LYNFE CLAIDSE $5: 46$

h. Axillary vessels

The exposure of the ontire extert of these vessels may be completel by the reflection of the pectoralis minor muscle. AXILLARY ARTERY $-48: 70$

HIGIEST THORAGIC ARPERY-49:I

TIORACOACRORTII, RRTERY $-49: 2$

I.ATGEAT THORACIC ARTERY $49: 7$

EXTERTAL MAIIARY RAMI-49:8

SUBSCAPILAR. ARTERY $.49: 9$

THORA CODORSAI ARTERY $-49: 10$

CIPCUIFIFX SCAPULAR ARTPRY.-49:11

AITEF.IOF CIRCUNIFEX HUIERAL ARTERY $\cdots 49: 12$

PCSTERTCR CIRCURILE HUIERA ARTERY-49:13

AXIIIAKY VEIN-54:29

IATSRA, THORACTC VIN $=54: 30$

THCRICOEPIGASTP.IC VEINS-54:32

CUCTOLXIILAFY VEITS-54:31

CEPHA ETC TEINT 5.1:3?

i. Subclavius mis:ie $24: 79$

j. Brachià? plexus

Its exposure may be completed - i.e. so far as it is related

to the axillary fossa - by detaching the subclavius muscle at its insertion, renoving the widile third of the ciavicle, and dividing the axillary artery ari vein at the level of the clavicle and $r e f l e c t i n g$ them distally.

LATER:L CORD-62:38

ANTERIOR THORACIC NERVE.69:29

IIUSCULOCITANEOUS NERVE. $69: 41$

IEIAN NERVE-69:48 Lateral head.

LEDIAL CORD-69:39

ANTERIOR THOPACID IERTE-69:29

IEDIAN NREVE-69:48 Ledial head.

UTHR IRRTE- $69: 55$

LEDTAT, ATTIBRA GHIAL CUTAIEOUS IERVE-69:45

IETAL EPACETAL CUTAINOUS NERVE-69:44

POSTERTJR COR D $-63: 40$

SUDECAIUIAR IERVES-69:32

THOT_ACDOF.SAT, INERVE-69:33

AXILIARY IURTE -69:34

RADIAL IERVE-69:65

SURCLAVIIIN VERTE-59:30

LOIG MHORACIO IFIRVI-60:28

k. Serratus anterior inusile-25:1 



\section{Superior Ixtreraity: general characterijtics.}

1. Subdivisions

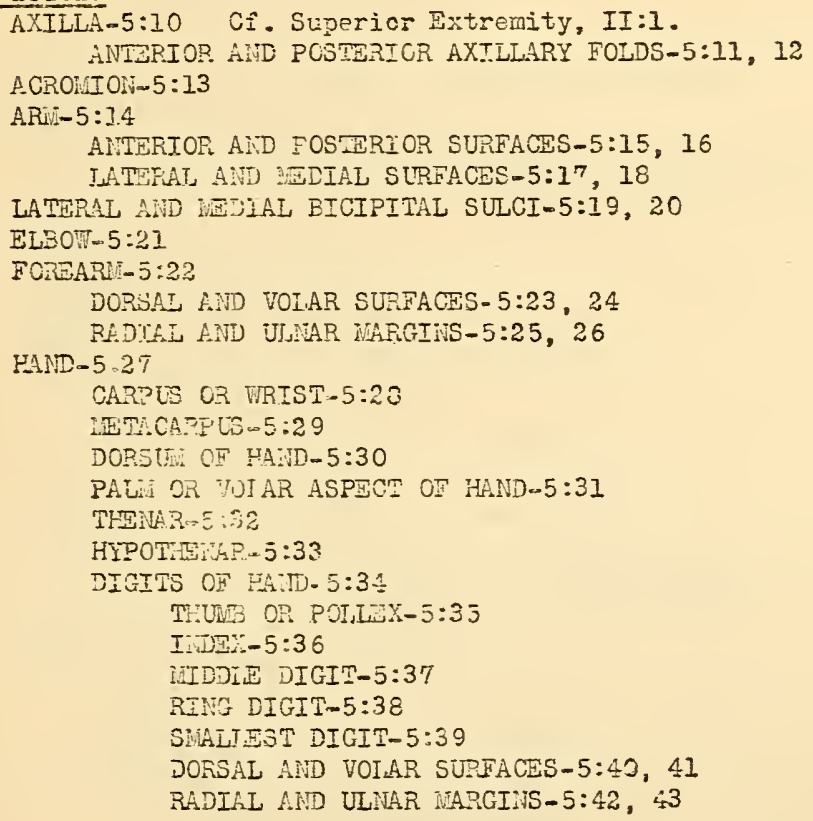

2. Regions of the superion extromi $\pm \mathrm{V}-83: 37$

ACROIIAI, REGION-83:38

DELTOID REGIO:T-83:39

LATERAI AND NEDIAI REGIONS OF ARI-83:40, 41

AITERIOR AID POSTERIOR REGIONS OF ARM-83:42, 43

ANTERIOR REGION: OF ELBOT-83:44

CUBITAI FOSSA $-83: 45$

POSTHRIOF. PEGION OF ELBOT-84:1

OLECRAIOT RECION-34:2

LATERAT, AND TEDIFI, REGIONS OF ELBOW-84:3, 4

VOLAR AII DCRSAI REGIONS OF FOREARH-E4:5, 6

RADIAL AO UINAR MARGINS OF FOREARI $-84: 7,8$

DORSAL AND VOIAR REGIONS OF UAND-84:9, 10

DIGITAL REGIONS OF HAND-84:11

DORSAI, UNGUICUTAR AND VOIAR REGIOIS OF DIGITS-84:12-14

\section{Rision of the 3houlder.}

1. Fascia, cutaneous nerves and cephailc vein.

SUPARFICIAL FASCIA-23:36

Exposed by reflecting the skin of the shoulder distally

as far as the insertion of the deltoid muscle.

POSTERIOR SUPRACIAVIICULAR NERVIS-69:20

LATERAL BRACHIAL, CJTAIEOUS NERVE-69:36

CEPHALIC VINI-54:37

DEPP FASCIA 


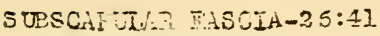

SURPASFINTCUS FAS

INERASPLITUS FESCIA-25:45

2. Muscles, nerves ve vels bnd li gaments of the shoulder

DEITOTD IRUSCT $2-2,5: 63$

SUBCUTAITOUS ACROIIAI, BURSA-28:22

The subsequent structures are exposed by detaching the deltoid muscle at its origin and reflecting the muscle toward its

insertion.

SUBDEITOID BUPSA- $=28: 24$

SUBACROHIAI, BJRSH-28:23

AINTEROE HUIURAI CIRCUITTEX ARTEPY $-49: 12$

POSTIETOR HUUEAL CIPCUIFIEX ARTERY-49:13

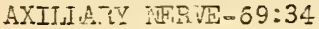

MUSCUTAR RAII- $69: 35$

LATERL CUTHEOUS NERVE OF THE ARH-69:36

TERTS NG: JOF. ZNUSCIE=25:67

BIJESA OF TEL TERTS MAJOR IUSCIE-28:28

PECTORALIS IFA $30 R$ MUSCLE-24:74 Insertion only.

LATISSTIIS LORS: 1,USCIE-23:17 Insertion only.

BTPSA OP THE LETICSNITS DORSI UUSCLE-28:29

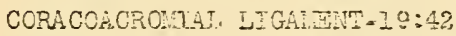

ACRONIOCLA UCLLAR AETTCUTATION $-29: 45$

ARTICUTA. CAPSUJS-19:46

ACROMOCLA TCULAR LIGA IENT-19:47

APTICULAR DISC-I9:43

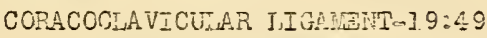

TYLEEOID TIGAIENT-19:50

COIJOID IICAIENT-19:51

The folloring muscles are exposed by saving timough the acromion at its junction bith the spine of the scapula, dividing the

fascia covering the teres minor muscle ard reflecting it

redially, but guariing at the same tine the circunflex artery of the scapula,

SUPRASPINOUS MUSCTE-25:64

TRPES IMTIOR NUSCTE-25:66

INRASPT:HTOUS NUSCLE $-25: 65$

SUBS:APJIALIS UUSCI $\$-25: 68$

BUASA OF MEJ SUBSCAPUTARTS MUSCIE-28:27

In demonetrating the following structures the infraspinatous and supraspiratcus muscles are divided near tineir insertions, and both muscles reflected towart their crigins.

BURSA OF THE INFRASPINATOUS BUSCIE-28:26

TPANS VERSE SCAPUEAR ARTERY-48:60

ACRONIAL RALTUS $-48: 61$

TRANIVVESSE SCAPULAR VETN: $54: 25$

SUPRAS CAPULAR IPRTE-69:31

CIRCUNAIEY SCAPUIAR ARTERY $-49: 11$

SUPERIOR TRA ITSVRSE SCAFULAR IIGAISIT-19:43

IHIERIOR TRANSVEPSE SCAPUIAR IIGAUEITT-19:44 

V. Arm and S.xerficjal Structures of the Forearm

Eno jursurat

1. Surface anatony of erm an foresst:

LATEPAL EICIP TIA SULCJS- $5: 19$

NEDTHI EICEPTTAL SULCUS-5:20

IRDIEI: IARGIN OF THS HUTERS-I4:4

DIHDIAL EPICONDYIE $=14: 11$

GROOVE FOR THE UINAR INERTE-14:8

LATERAL NIARGIN OF THE FUUSRUS-14:5

IATEPA I FPICONDY:EE-14:12

OLTCRANON $=14: 19$

STYIOID PROCESS OF THE RADIUS-14:30

DORSAI IIARGIN CF THE ULNA-14:44

STYLOT PBCCES OF THE ULRA-14:49

2. Arm (anterior aspect) and foream: superficial structures

a. Cutaneous nerves

Skin incisions: a) along the middle line of the anterior surface of the ary and the volar surface of the forearm to the level of the radiccarpel articulation; b) transversely around the forearm just proxtrai to the vadjocarpal articulation.

INTERCOETUFRACHLAL IER.ES-70:7

INDIAL ANTEBRECHIAI, CUTANEOUS NERVE-69:45

UINAP RADUG $69: 47$

VJLAR RUIUUS-69:46

IEDIAL BRACHTAL CUIANOUUS NQRVA-69:44

PCSTERTOR BRACHIAL CUTANBOUS IRRVE-69:66

DORSAI ANITBRACHEAI CUTAIEOUS IERVE-69:68

LATERAL ANIIBRACHIAL CUTANEOUS IERVE-69:43

$\frac{\text { b. Voins and I vaphatics }}{\text { BASIIC VEI }}$

CAP:ALIC VIDIN-54:35

IEDIAN VEIN OF THE ELBON-54:40

In cases where the preceding vein is absent, the following veins may take its place:

MEDIAN VETN OF THE FOREARN-54:41

WEDIFN EASILIC VEIN-54:42

HEDIFI CEPHALIC VEIT-54:43

SUPEREICIAI IYAFH GLAIDS OF THE ELBOW-56:49

3. Arn (anterior aspect): deep structures.

a. Deep fascia-

ERACHIAI FHECIA-2 6:44

LACERTLS FIBEOSUS- $25: 73$

The following fascial septa are jemonstrated by diviaing the brachial fascia by a longitudinal incision along the median lins of the front of the arm and reflecting the medial and lateral flaps of deep fascia, leaving intact, however, the lacertus fiorosus. MEDIAL INTERIUSCUAAR SEPTUI $-26: 45$

IATERAL INTERUSCYLAR SEPTUP-26:46 

b. Arteries

BRACHIAL ARTERY-49:14

DEEP BRACHIAI, APIERX-49:15

SUPERTCR ULIAR COLLATERAL ARTERY-49:20

INTERIOR ULNAR COLIATERAL ARTERY-49:21

c. Veins

BRACHIAI VEINS - 54:34

BASILIC VEIN $-54: 39$

CEPHALIC VEIN-54:37

d. Nerves

INDIAL BRACHIAL CUTANEOUS NERVE-69:44

IEDIAL ANTIBRACHIAL CUTANEOUS NERVE-69:45

IEDIAN INRVE-69:48

ULNAR NERVIS-59:55

WUSCULOCUTANEOUS NERVE-69:41

MIJSCUIAAT FAIII-69:42

LATERAL ANI $-B R A C H I A L$ CUTANEUS NERVE-69:43

e. Wuscles

BICEPS BRACHII NUSSII $-25: 69$

LONG HEAD-25:70 Not including its origin.

SHORT HEAD $=25: 72$

CORACOBRACHIALIS BAUSCLE-25:7\%

4. Cubital fossa-83:45

The following structures are dealt with here only in so far as they are related to the cubital fossa.

BRACHIAL ARTERY $-49: 14$

RADIAL ARTERY $-49: 22$

ULNAR ARTERY-49:36

TEIDON OT EICEPS BPACHII MUSCLI

MFIAN NEP.VE-69:48

BRACHIALIS WUSCIE-25:75

SUPINATOR IUUSCLE-26:24

The following structures are exposed by dividing the lacertus fibrosus and widening the space between the pronator teres and brachioradialis muscles.

PADIAI NERVE-69:65

DEEP RAIUUS $-69: 69$

SUPRRFICIAL RAMUS $-60: 71$

RADIAL RECURREHT ARTERY-49:23

INFERIOR ULNAR COLIATERAI ARTIRY -49:21

ULIAT RECURRENT ARIERY-49:47 Volar.

5. Arm: posterion aspect

TRICEPS BFHCHII MUSULE-2 5:76

LONG HEAD-25:77

LATERAL HEAD-2 5:78

INEDIAL HEAD-25:79

RADIAL NERVE-69:65

Exposed by dividing the lateral head of the tricepa muscle along the course of the ridial nerve.

POSTYRIOR CUIANEOUS INRVE OF THE ARH-69:66

INUSCULAR RAIII-69:67

POSTERIOR CUTAMEOUS IERVE OF THE FOREAPH- $69: 68$ 

DEPP BRACHFAL ARTER

DELTOID RAMUS-49:17

NIDDLE COLLATERAI ARTERY-49:18

RADIAL COLIATERAJ ARIERY-49:19

NUIRIENT ARTERTES GF THE HUNERUS-49:16

ULNAR IERVE-59:55

SUPERIOR ULNAR COLIATERAL ARTERY-49:20

INEERIOR ILNAR COLTATERAL ARTERY-49:2I

SUBTENDINOUS BURSA OF THE OLECRAIVON-28:32

6. Dorsum of the hand: superficial structures

Skin incisions: a) along the radial and ulnar margins of the hand; $b$; along the middle line of the dorsal aspect of each digit. SUPEPFICIAL RAMUS OF THE RADIAL NERVE-69:71

ULNAR ANASTOMOTIC RAMUS-69:72

DORSAL DIGITAL NRRES-69:73

DORSAL RANUS OF THE FAND FFON THE ULNAR NERVE-69:57

DORSAL DIGITAL NERVES-69:53

VENOUS IETWORI OF THE BACK OF THE HAND - 54:44

DORSAL IETACARPAL VIILS-54:49

DIGITAL VENOUS AFCH-54:52

DORSAL FASCIA OF THE HAND.-26:50

DORSAL CARPAL IIGATENT-26:51

7. Forearm: volar aspect and ulnar margin

a. Deep fascia and cutaneous nerves piercing it

For the stiperficial fascia and certain cutaneous nerves of the

forearn, see Superior Extremity, $V: 2$.

FASCIA CF THE FOREARI-2E: $\$ 9$

PALMAR CUIANEOUS RAIUS UF THE ULNAR NERVE-69:56

PALIAR RANUS OF THE FEDIAN :LERVE-69:51

SUPERFICIAL RAIUSS OF PHE RADIAI NERVE-69:71

VOLAR CARPAL LIGAIENT-26:55

b. Radial artery and nerve

Exposed by turning aside the volar ramus of the medial cutaneous nerve of the forearm, the lateral cutaneous nerve of the forearm, the superficial veins, and removing the deep fascia of the forearm except where it gives origin to underlying muscles.

PADIAL ARTERI-49:22

RADTAL RECURRENT ARTERY $-49: 23$

SUPTRIICIAL VOLAE RAIUS-49:26

IMUSCULAR RAMI-49:24

VOLARCCARPAI RAIIUS-49:25

RADIAL NERVE-69:65

DEZP RAMUS-59:69 Origin only

SUPEREICIAL RAIIUS-59:71

c. Superficial muscles

BRACHIORDIALIS NUSCLE-2 6:17

PALIARIS LONGUS IUUSCLA:-26:7

PRONATOR TERES IUUSCIE-26:3

HUWERAL HEAD-26:4

ULIAAR HEAD-26:5

FLEXOR CARPI RADIALIS MUSCIE-26:6

FLEXOR CARPI ULNARIS NUSCIE-26:8 

HUERAL HEAD-26:9

ULNAR HESD-26:10

FLEXOR DIETTORUA SUBIINIS-26:11

HUIERAL HEAD-26:12

ULNAR HEAD-26:13

d. Ulnar vessels and median nerve

ULNAR AMRERY $+49: 36$

RECLRRENI ULNAR ARTERIES-49:37

COMUN INTEROSSEOUS ARTERY-49:39

VOIAR INTEROSSEOUS ARTERY-49:42 Origin only.

DORSAL INTEROSSEOUS ARTERY-49:40 Origin onIy.

VOLAR CARPAL RAIIUS-49:46

DORSAL CARPAL RAMUS-49:45

MUSCULAR PAII-49:44

ULNAR VEINS-54:36

ULNAR IERVE-69:55

PAIIMAR CUTAPEOUS RAIII-69:56

DOFSAL RANUS OI THE THND-69:57

VOLAR BAIUUS OF THE HAND-69:59 Origin only.

MUSCULAR RAHI-60:64

IEDIAN NGR泟-69:48

Exposed by reflecting the humeral head of the pronator teres muscle and the radial head of the flexor digitorum sublimis muscle.

MUSCULAR RAII-69:49

VOLAR INTEROSSEOUS NERVE OF THE FOREARH-69:50 Origin only. PALMAR RAIUS OF THE IEDIAN NERVE-69:5I Origin only.

e. Deep structures on the volar aspect of the forearm

FLEXOR DIGITORUM PROFU.DDUS NUSCLE-26:14

FERXOR POLIICIS LONGUS INUSCIN-26:15

PRONKTOR QUADRATUS MUSCIE-26:16

VOLAR INTSROSSEOUS ARTERY $-49: 42$

NIEIAN ARTERY-49:43

MIUSCULAR RAMI- $-9: 44$

VOLAR. INTEROSSEOUS INERVE- 69:50

\section{Wrist and Hand: Volar Aspect}

1. Surface anatomy

THEINAR ENINENCE $-5: 32$

HYPOTHENAR ENINENCE-5:33

TUBEFCLE OF THE IAVICULAR BOB⿺辶-14:54.

TUBERCLE OF THE GRTATER MULTANGULAR BORH-14:59

PISIFORM BONE-14:57

IETACARPAI BONES-14:68

PHALANGSS $-14: 74$

2. Fascia and cutaneous nerves

Skin incisions: a) longitudinally along the middle line of the

palm; b) transversely at the level of the proximal ends of the interdigital clefts from the radial to the ulnar margin of the hand; c) longiturinally along the middle line of each digit. SUPEPFICIAL FASCIA-23:36

PALIVARIS BREVIS IIUSCLE-26:29

PALIIAR BRANCH OF THE IIEDIAN INERVE-69:51 

PALIJAR CUTANEOUS BRANCH OF THE ULNAR INERVE-69:56

SUPERFICIAL BRANCH OF THE RADIAL NERVE-69:71

PALIAAR APONE UROSIS-26:52

TRANSVERSE FASICULI-26:53

VOLAR CARPAL LIGAMENT-2 6:55

3. Muscles, nerves, vessels and ligaments

$\frac{\text { a. Nerves and vessels superficial to the muscles and flexor tendons }}{\text { of the palm. }}$ Exposed by dividing the proximal part of the palmar aponeurosis transversely, reflecting it distally and then removing the entire aponeurosis together with the palmaris brevis muscle and the volar carpal ligament.

SUPERFICIAL VOLAR ARCH-49:48

SUPERFICIAL VOLAR RAMUS OF THE RADIAL ARTERY-49:26

COMGION VOIAR DIGITAL ARTERIES-49:49

PBODER VCEAR DIGTMAL ARTEPT-S-49:50

MEDIAN NERVE-69:48

MUSCULAR RAII-69:49

COMAON VOLAR DIGITAL NERVES-69:53

PROPER VOLAR DIGITAL NERVES-69:54

VOLAR RANUS OF THE ULNAR NERVE IN THE MAND-69:50

DEEP RAMUS-69:63 Origin only.

SUPERFICIAL RANUS-69:60

COMNON VOLAR DIGITAL NERVES-69:61

PROPER VOLAR DIGITAL NERVES-69:62

b. Ligaments and mucous sheaths of the flexor tendons

TRANS VERSE CARPAL LIGAMENT-26:54

VAGINA TENDINUA MAN. FLEXORUM COMAUNIUH-28:48

VAGINA TENDINIS $\pi$. FLEXORIS POLLICIS LONGI-28:49

VAGINAL LIGAIRNTS OF THE DIGITS-26:59

ANNULAR LIGAIENTS OF THE DIGITS-26:60

CRUCIATE LIGABIENTS OF THE DIGITS-26:61

VINCULUII TENDINUR-26:57

CARPAL CANAL-20:24

CHIASMA TENDINUM-26:56

c. Muscles

LUMBRICALES NUSCLES-26:37

Expcsed $b_{y}$ dividing the superficial volar arch just distal

to the deep ramus of the ulnar artery and also at its junction with the superficial volar ramus of the radial artery and reflecting the arch distally, dividing the median nerve nt the level of the wrist and reflecting it distally, and dividing the flexor digitorum sublinis muscle at the middle of the forearm and reflecting the distal part toward its insertion.

The demonstration of the following structures may be completed by dividing the flexor digitorum profundus in the forearm and reflec. ting it and the 1 umbricales muscles toward their insertions, noting at the same time the muscular rami from the deep branch of the ulnar nerve to the two (ulnar) lumbrical muscles. ABDUCTOR POLIICIS BREVIS MUSCLE-26:30

OPPONENS POLIICIS MUSCLE-26:32

ADDUCTOR POLUIS MUSCLE 

ADDUCTOR POLIICIS IUSCIE-26:33

ABDUCTCR DIGITI QUINT MUSCLE-26:34

FLEXOR DIGI 2UINTI BRUVIS NUSCE-26:35

OPPONEIS DIGIII QUINTI MUSCLE-26:36

d. Nerves and vessels, internal to the flexor tendons and muscles of ting pain.

DEQP RAIUS OF TIS ULNAR IPRVE-69:63

MUSCULAR RAIII-69:64

DEPP VOLAR ARC:I-49:33

VOIMR IFTHCARPAI ARTERIES-49:34

PIRPOPATING RAII-49:35

PRINCPS POLLICIS ARTERY-49:31

Demonstrated by detachins the adductor pollicis muscle at its crigin and reflecting it toward its insertion.

VOLAR RADIAL ARTERY CF THE INDEX DIGIT-49:32

\section{Toreeril: Dorsal Aspect and Radial Vargin}

1. Fascia, muscles, nerves and vessels

a. Deep fascia of forearm

For the supericial fascia, cutaneous nerves and superficial

vessels, see Superior Extremity, $V: 2$.

FASCIA OR FOREARUi-26:49

DORSAI CARPAI: LIGAMETT-26:51

b. Superficial muscles

Exposed by removing the deep fascia froli the dorsum of the foreari, except where it gives origin to subjacent muscies as in the region of the elbow (retaining intact, however, the dorsal carpal

ligament).

BRACHIOR DIALIS MUSCLE-26:17

EXTENSOR CARPI RADIALIS LONGUS HUSCIE-26:18

EXTLNSOR CAPPI RADIALIS BREVIS IGUSCLE-26:19

BURSA OF THE EXTENSOR CARPI RADIALIS BREVIS MUSCIE-28:43

EXIENSOR DIGITORUI CONMUNIS INUSCLE-26:20

EXTPISSOR DIGITI QUTINTI PROPRIUS MUSCLE-26:22

AINCONATUS INUSCLE-26:I

EXTENSOR CAPPI ULIARIS MUSCLE-26:23

c. Nerves and vessels

Exposed by dividing the extensor digitorum conmunis and extensor

digiti quinti muscles at the middle of the forearm, and reflecting the proximal and distal segmerts of the divided muscles toward their origin and insertion, respectively.

DORSAL INTEROSSEOUS ARTERY $-49: 40$

RECURRENT INTEROSSEOUS ARTERY $-49: 41$

ARTERIAL IFTWORK OF THE EIBON-49:38

VCLAP. INTEPOSSEOUS AKTERY-49:42

DPEP RAIUUS OF THE RADIAL INRVI-69:69

DORSAL INTMROSSEOUS IURVE-69:70

d. Deep muscles 

EXTENSOR POLIIITS BRETIS MUSCLI-26:26

EXIENSCR POLLICIS LONGUS MUSCLE-20:27

EXIENSOR INDICIS PROPRIUS MUSCLE-26:28

SUPINATOR NUSCLE-2 6:24

\section{Wrist and Hand: Dorsal Aspect}

1. Muscles, nerves and vessels

a. Vessels

For the cutaneous rerves and superficial vessels see Superior

Extremity, $\mathrm{V}: 6$.

RADIAI ARTERY-49:22

DORSAL CARPAI RAMUS-49:27

DORSAL CARPAL RETE-49:28

DORSAL IETACARPAL ARTERIRS-49:29

DORSAL DIGITAL ARTERIES-49:30

PERTORATING RAIII-49:35

b. Muscles, nerves and ligaments

DORSAL CARPAI LIGAMENT-2 6:51

JUNCTURA TENDINULI-26:2?

DORSAL INTEROSSEOUS NERVE-69:70

TRANSVERSE LIGANENTS OF THE TEADS OF THE METACARPAL BONES-20:41

VOLAR INTEROSSEOUS NUUSCLES $-26: 39$

DORSAL INTEROSSEOUS MUSCLES-26:38

FLEXOR POLLICIS BREVIS MUSCLE-26:31 Deep head.

Demonstrated by reflecting the radial head of the first dorsal interosseous muscle.

FIEXOR CARPI RADTALIS IMUSCLE-26:6

IX. Articulations of the Superior Extremity

1. Shoulder joint-19:58

ARTICULAR CAPSULE-19:59

CORACOHUIERAL IICAIIENI-19:61

GLENOID LIP-19:60

LONG HEAD OF THE BICEPS NUSCLE-25:70

SYNOVIAL IEMBRAIN-18:32

INIERTUBERCULAR MUCOUS SHEATH-25:71

BURSA SUBSCAPULARIS $-28: 28$

2. Elbow joint-19:62

ARTICULAR CAPSULE-19:66

ULNAR COLIATERAL IIGANENT-19:67

RADIAL COLIATERAL LIGANDET $19: 68$

SYNOVIAL IHIJBRANE-18:32

HUNEROULIAR ARTICULATION-19:63

HUMERORADIAI ARTICUIATIOI-19:64

3. Joint of the hand $-20: 8$

a. Radiocarpal articulation-20:9 ARTICULAR CAFSULE-20:11 

VOLAR PAIIOCOARAL LIGAMRNT-20:13

ULNAR COLLATERAL CARPAL LIGAIE:T-20:15

RADIAL COLIATERAL CARPAL LIGAITENT-20:16

3. Intercarpal articulation-20:10

ARTICULAR CAPSULE-20:11

RADIATE CARPAL LIGANENT-20:14

DORSAL INTERCARPAL LIGAIENIS-20:17

VOLAR INTERCARPAL LIGANEITS-20:18

INTEROSSEOUS INTERCARPAI LIGANENTS-20:19

4. Pisiform articulation-20:20

ARTICULAR CAPSULR-20:21

PISOHANATE LIGANENT-20:22

PISOIETACARPAL LIGAIENT-20:203

CARPAL CAIIAL-20:24

इ. Radioulnar articulations

PROXINAT RADIOULNAR ARTICULATION-19:65

ANNULAR LIGANENT OF THE RADIUS-19:69

RECESSUS SACCIFORUISS-20:1

DISTAL RADIOULNAR ARTICULATION-20:4

ARTICULAR DISC-20:6

ARTICULAR CAPSULE-20:5

RECESSUS SACCIFORIIS-20:7

INTEROSSEOUS IEIBRANE OF FOREARM-20:2

OBLIQUE CORD-20:3

6. Carpometacarpal articulations $-20: 25$

ARTICULAR CAPSULES $=20: 32$

DORSAI CARPOIETACARPAL LIGAIEENTS-20:27

VOLAR CARPOIETACARPAL LIGAIEENIS-20:28

CARPONETACARPAL ARTICULATION OF THE THUMB-20:29

ARTICULAR CAPSULE-20:30

7. Intermetacarpal articulations $-20: 31$

ARTICULAR CAPSULDS-20:32

DORSAL BASAI IIGAIENTS-20:33

VOLAR BASAL LIGAIENTS-20:34

INIEROSSEOUS BASAL LIGAIENTS-20:35

8. Metacarpophalangeal articulations-20:37

ARTICULAR CAPSULES-20:38

COLLATERAL JIGAMENTS-20:39

VOLAR ACCESSORY IIGAIENTS-20:40

TRANSVERSE LIGANENTS OF THE HEADS OF THE IRTACARPAL BOIVS-20:41

9. Articulations of the digits $-20: 42$

ARTICULAR CAPSULES-20:43

COLLATERAL LIGAIENTS-20:44 

$\mathrm{TH} O \mathrm{BAX}$

- - - -

$A N D$ DER STRUCTUEES OF THE BACK 



\section{General Characteristics}

1. Subdivisions of thorax and back

THORAX $-4: 47$

THORACIC CAVITY $-4: 48$

BREAST $-4: 49$

MARMLA $-4: 50$

MAMRARY PAPILIAA $-4: 51$

$B A C K=4: 52$

VERTEBRAL COLUMN-4:53

SPINAL CANAL-4:54

2. Surface angtomy

For the surface anatomy of the thorax and back see Superior Extremity, I:I and II:I.

3. General osteological characteristics of thorax

THORACIC CAVITY -7:58

SUPERIOR APERTURE OF THE THORAX-7:59

INFERIOR APERTURE OF THE THORAX-7:60

COSTAL ARCHES $-7: 61$

INTERCOSTAT, SPACES $-7: 62$

INFRASTERNAL ANGLE-7:63

4. Regions of thorax and back

For regions of the thorax and back refer to Superior Extremity, $I: 2$, and $I I: 2$.

\section{Thoracic Wall: Anterior and Lateral Parts}

1. Intercostal muscles, ligaments and nerves

For structures of the thoracic wall external to the costal arches and intercostal muscles see Superior Extremity, II:3, 4. EXTERNAL INTERCOSTAL MUSCLES-25:5

EXTERNAL INTERCOSTAL LIGAMENTS-19:32

INTERNAL INTERCOSTAL MUSCLES-25:6

Exposed by dividing the external intercostal muscles and external intercostal ligaments along the inferior margins of the intercostal spaces and reflecting the muscles and ligaments upward.

INTERNAL INTERCOSTAL LIGAMENTS-19:33

ANTERIOR RAMI (INTERCOSTAL NERVES) OF THORACIC NERVES-70:1

MUSCULAR RAII-70:2

LATERAL CUTANEOUS RAMI-70:3

POSTERIOR AND ANTERIOR RANI-70:4, 5

LATERAL MAMMARY RANI-70:6

INTERCOSTOBRACHIAL NERVES-70:7

ANTERIOR CUTANEOUS RAMI-70:8

MEDIAL MAMMARY RAMI-70:9 



\section{Blood Vessels}

HIGHEST INTERCOSTAL ARTERY-43:63

INTEPCOSTAL ARTERIES-49:59

ANTERIOR RAII-49:65

IIUSCUIAAR PANI-49:66

LATERAT, CUTANEOUS RAIII-49:67

POSTERIOR RAIII-49:68

ANTERIOR RAMI-50:1

LATERAL MAIMARY RAMI-50:2

ANTERIOR CUTANEOUS RAIII $-5 n: 3$

NiEIIAI WANIARY RAVI-50:4

POSTERIOR RAIS-49:60 See also Superior Extremity, I:3.

INTERCOSTAL VEINS-54:56

INTERHEL IIMIARY ARTERY-48:34

Exposed by removing the intercostal muscles and ligaments

from the anterior ends of the intercostal spaces, guarding

against injury to tine pleura.

STERIAL PA:II-48:39

PERFCRATING RAMI-48:40

MAIRTARY RAMI-48:41

MUSCIJAR FAMI-48:42

CUNANECUS RAIII- $48: 43$

INTERCOSTAL RANI-44:45

NUSCULOPHRENIC APTERY-44:46

Exposed by cutting sway the medial end of the sixth costal cartilage.

SUPEFIOR EPICASTRIC ARTERY-44:47 Its origin only.

INTERIAE NALIAPYY VEIN-52:65

TRANSVERSE THORACIC IUSCLE-25:8

\section{Thoracic Cavity and Viscera}

1. Pleura and pleviral cavities

The pleura is exposed by removing the intercostal muscles, separating the pieura from the internal surfaces of the sternum and ribs, and with a saw and bone-forceps, removing the sternum and costal arches by the following incisions, but retaining the pleura intact? a) transversely through the sternum at the level of the lower margin of the first costosternal junction; b) transversely through the sternum at the level of the upper margin of the sixth costosternal junction; c) dividing the second, third, fourth, and fifth ribs at the junction of the middle and posterior thirds of each.

ENDOTHORACIC FASCIA-38:2

The pericardium may be identified by inserting the finger between the lines of sternal reflection of the rigit and ieft pieurae and passing it through the areolar tissue of the anterior mediastinal cavity.

Incisions through the pleura exposing the pleural cavity: a) longitudinally through the costal pleura midway between the sternum and vertetral column extending from the first to the sixth rib; b) transversely along the inferior margin of the first rib and along the superior margin of the sixth rib, extynding 

medially to within about $2 \mathrm{~cm}$. of the line of sternal reflection of the pleura and laterally to the line of the cut ends of the second to fifth ribs. PULMOIJARY LIGAIRNT-38:16

CUPULA OF PIEIRA-38:5

PULIFONARY PY RIRA-38:6

PARIETAL PIEURA-38:7

COSTAL PIEURA-38:11

MEDIASTINAL PLEURA-38:8

INEDIASTINAL LAYERS $-38: 9$

PERICARDIAL PIEURA-38:1C

DIAPHRAGIATIC PLEURA-38:12

PLEURAL SINUSES-38:13

PHREITLCOCOSTAL SINUS-38:14

COS + ONLEIASTINAL SINUS-38:15

ADIPOSE FOIDS-38:17

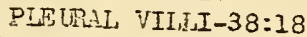

MEDIASTTNAT, SEPTUM-38:19

LNTRIOR NEDTASTINAL CAVITY-38:20

POSTERIOR MEDIASTIMAL CAVITY-38:2]

2. Lungs.

The lung is removed by dividing its root close to the medial surface of the lung.

a. Surface a na tomy of Iunge

BASE OF LUNG-57:57

APEX OF LUNG-37:58

COSTAL SURFACE $-37: 60$

MEDIASTINAL SURFACE-37:61

DIAPHRAGMATIC SURFACE $-37: 62$

ANTERIOR IIARGIN-37:63

INFERIOR INARGIN-37:64

HILUS OF LUNG-37:65

ROOT OF LUNG $-37: 66$

SUBCLAVIAN GROOVE-37:59

INTE:RLOBAR INCIS URE-37:71

SUPERIOR LOBE-37:68

UIDDLE LOBE-37:69

INFERIOR LOBE-37:70

CARDIAC NOTCH $-37: 67$

b. Internal structure of lungs

BRONCHI-37:41

Demonstrated by tearing and removing parts of the pulmonary

tissue and following the bronchi and blood vessels and their subdivisions as far as possible into the substance of the lung.

BRONCHIOIES $-37: 74$

RESPIRATORY BRONCHIOLES-37:75

ALVEOLAR DUCTUIES. $37: 76$

PULNONARY ALVEOLI-37:77

BRONCHIAL LYRPH GLANDS $-37: 78$

BRONCHIAL LYMPHATIC NODULES-37:79

PULMONARY LIMPH GIANDS-37:80 

3. Root of lung and related structures

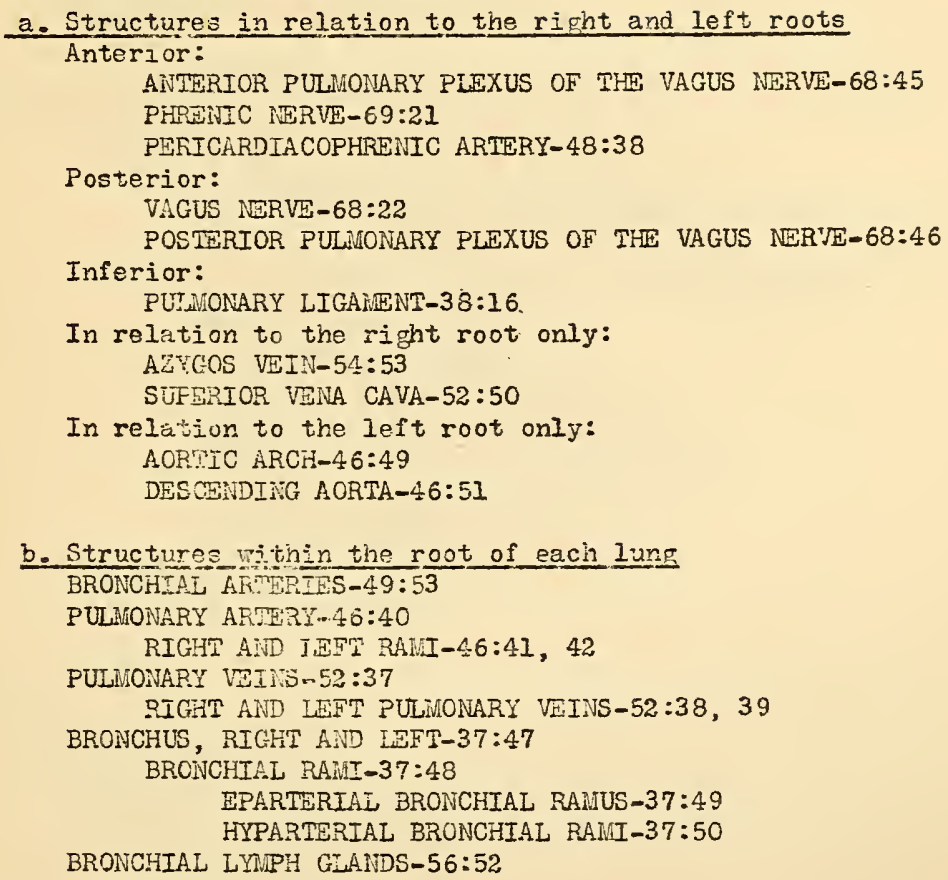

4. Phrenic nerve and nerves to the superficial part of the cardiac plexus

PHRENIC NERVE-69:2I

PERICARDIAC RARUS $-69: 22$

PHRENICOABDONINAL RAIII-69:23

Nerves in relation to the superficial part of the cardiac plexus: SUPERIOR CARDIAC IVERVE-71:59 From the cervical sympathetic. INFERIOR CARDIAC RAMUS-68:37 From the left vagus nerve. CARDIAC GANGLION-72:11

5. Thymus $-38: 31$

Usually in a condition of atrophy in the adult, but showing the following structures in the child:

RIGHI AIND LEFT LOBES-38:32

CENTRAL TRACT-38:33

LOBULES OF THE THYIIJS-33:34

\section{Peridardium}

STERNOPERICARDIAL LIGAIIENIS $-45: 43$

Incisions exposing the pericardial cavity: a) Iongitudinally through the pericardium from the aorta to the diaphragm; b) transversely from the middle of the right to the middle of the left root of the lung. 

PERICARDT.UN-45:4I

EPICARIITI:-45:45

PERICARJTAL FIJID $45: 42$

TRANSTERSE SINUS OF THE PERICARDIULI-45:44

\section{Great veins of the therax and their tributaries}

SUPERIOR VENA' CAVA-52:50

RIGHT AD LEET INNORINATE VIINS-52:51

INHEIOR THYREOID VEINS $52: 52$ Termination only.

THYFEOIDEA IMA VEIN-52:53

The inst five of the following tributaries are small

and usually difficult to demonstrate:

THNIC VEIINS - 52:56

PETCARDIAC VEINS-52:57

BUPIPTOR. PIRENIC VEINS-52:58

AITTESTOR MEJIASTINAL VEINS= $52: 59$

ANTTEIOR BRONCHTAI, VEINS $-52: 60$

VERTEBRAL VETN 52:53 Termination only.

INTHNAL WIALEARY VEIN-52:65

HIGHEST IIVTERCOSTAL VETN-52:68

AZYGOS VIIJN-54:53

INFERIOR VENA CAVA $=55: 3$

8. Heart and aorta

a. Surface anatomy

APEX OE HEA $:=45: 36$

STERNOCOSFAL SURFACE-45:34

DIAPHRAGMATIC SUPEACE- $45: 35$

RIGHT ATRILU. $46: 3$.

RICHT AUFICIE-46:7

IEFT ATPLIUL- $-6: 26$

LETT AUTICT $\$=46: 27$

RIGHT VENPRICTE-46:13

IFFT VENTPICIE- $16: 29$

CORONARY SULCUS..45:40

ANTERIOR LOMGITUITIAT, SULCUS $-45: 38$

POSIERTOR LONGITUIMNA, SULCUS- $45: 39$

NOTCH AT APIX OF IEART-45:37

b. Nerve and vascu?ar supp]y

RIGHT CQRCNAIY ARTERY OF THE HEART-46:52

POSTERIOR DESCEINDING RANUS - 40:53

LEFT CORONARY ARTERY OF THS HEART - $46: 54$

CIRCTUWIEX RAMUS-46:55

ANTERIOR DESCENDING RAMUS-46:56

CORONARY SINUS-52:41

GREAT CARIIAC VEIN-52:42

POSTERIOR VEIN OF IEFT VENTRTCLF-52:43

CBLIQUE VEIN OF LETI ATRIUIN-52:44

MIDDLE CARDIAC VETIṼ-5\%:40

SMALL CARDIAC VETIIN:5: $: 47$

ANTERIOR VEINS OF TYE HEATT $30: 48$

SMALLEST VEINS OF THE HEAR?: 52:49

ANTERIOR CORORIARY PIARUE -7\%:10

POSTERIOR CORONARI PLEXUS $-72: 12$ 

c. Cavities of the heart. Dulmonarv vessels

RIGHT ATRIUM $-46: 1$

Incisions exposing the cavity af the right atrium:

a) Iongiturinally from a point just anterior to the superior vena cava, domnward and backward to the inferior rena cava; b) from the middle point of the preceding incision obliquely upward to the tip of the right auricle. EPICARDIUII $-45: 45$

INYOCARDIUM $-45: 46$

ENDOCARDIUVi- $45: 47$

SULCUS TERNINALIS OF RIGHT ATRIUN-46:3

CRISTA TERNINALIS-46:4

SINUS VENARUH CARVARUM $-46: 5$

PEOTINATE MUSCLES $-46: 2$

INTERVENOUS TUBERCLE $-46: 8$

SEPTUI CF THE ATRIA-45:54

NEIIBRANOUS PART-45:55

FOSSA OVALIS $-46: 1.0$

LPNBUS FOSSAE OVALIS-46:6

VALVE OF THE INFERIOR VENA CAVA-46:9

VATUE OF THE COROMARY SIITUE-46:II

VENOUS ORIFICE $+5: 56$

FORAIMINA OF THE SNALLEST CARDIAC VEINS-46:12

RIGHT VENTRICLD-46:13

Incisions exposing the cavity of the right ventricle:

a) irori the diaphragmatic surface of the heart upward $\frac{1}{2} \mathrm{~cm}$. to the right of and parallel with the anterior longitudinal sulclis to the origin of the pulmonary artery; b) from the upper end of the preceding incision transversely to the right, parallel with and $l \mathrm{~cm}$. inferior to the coronary sulcus.

CONUS ARTERIOSUS-46:19

SUPRAVEITRICULAF CREST-46:18

VENOUS ORIFTCE-45:56

TRIUUSPID VALVE-46:14

ANTERIOR CUSP-46:15

POSTERIOR CUSP-46:16

INEDIAL CUSP-46:17

PAPILIARY IUSCLES $-45: 60$

CHORDAI: TENDINAE-45:61

TRABECULAE CARIEAE-45:58

PULMOIJARY ARTERY $-46: 40$

RIGHT AND LEFT RAMUS-46:4I, 42

IICANENTUM ARTERIOSUN-46:44

DLGTUS ARTERTOSUS ${ }^{\mathrm{x}}-46: 43$

ARTERIAI ORIFICE LOF RIGHT VENTRICLE

SEMILUNAR VALVES OF PULIONAPY ARTERY-46:20

ANTEPIOR, FIGHT, AND IEFT SEMILUNAR VALVES-46:21,23

NODULES OF THE SEIIJU:TAR VAIVES-46:24

LUNULAE OF THE SEVIILUINAR VALVES-46:25

LEFT ATRIUU $-46: 26$

The cavity and vascular commuications of the left atrium are exposed by dividing the inferior vena cava, turning the heart upward and making an incision through the left atrial vali extending from the midile of its posterior margin forward to the tip of the left auricle. 



\section{VALVI OU THE FORAINAN OVALIS-46:28 \\ LEFT VENTRICLE-46:29}

Inciscions exposing the cavity of the left ventricle:

a) beginning near tise coronary sulcus anteriorly and extending parallel and $l \mathrm{~cm}$. to the left of the anterior longituniel sulcus to the apex of the heart; b) beginning posteriorly near the coronary sulcus and extending parallel and $I \mathrm{~cm}$. to the left of the posterior longitudinal sulcus and joining the end of the first incision at the apex of the heart. TPABECULAE CARNEAE-45:58

PAPILLARY MUSCLES $-45: 60$

CHORDAE TENDINEAE-45:61

VENOUS ORIFICE $-45: 56$

ARTERIAL ORIFICE-45:57

BICUSPID VALVE-46:30 ANTERIOR AND POSTERIOR CUSPS-46:31, 32

VENTRICULAR SEPTUM-45:49 MUSCULAR SEPTUM OF VENTRICLE-45:50 IUIMRANOUS SEPTURA OF VENTRICLE-45:5I

\section{d. Aorta and its branches}

ASCENDING AORTA $-46: 46$

BULB OF AORTA-46:47

SINUS OF AORTA-46:48

RIGHT AND IEFT CORONARY ARTERIES-46:52, 54 AORTIC ARCH-46:49

ISTHUUS OF AORTA-46:50

INNOIINE.TE ARTERY-46:57

(THYREOIDEA IINA ARTERY) $-46: 58$

COIRON CAROTID ARTERY [IEFT]-46:50

SUBCLAVIAN ARTERY LLFT $-48: 20$

DESCEIDIIN AORTA ITHORACIC PORTION-46:51 Origin only. SEMILUNAR VALVES OF AORTA-46:33

RIGHT, LEPT AND POSTERIOR SEIILUNAR VALVES-46:34-36

NODULAS AND LUNULAE OF THE SEMILUNAR VALVES-46:37. 38

\section{e. Myocardium and fibrous rigss of the heart}

The subsequent structures are exposed to better advantage after the great blood vessels have been divided near their juncture with the heart and the heart removed.

ATRIOVENTRICULAR BUNDLE OF HIS

Demonstrated more favorably in the sheep's heart. FIEROUS RINGS $-45: 63$

Exposed by removing the atria of the heart. FIBROUS TRIGONES-45:62

f. Cardiac plexus

For the superficial part of the cardiac plexus, see III:4. The following nerves entering into the formation of the deep part of the cardiac plexus are exposed by dividing the aortic arch at its junction with the descending aorta and turning aside the aortic arch.

MIDDLE CARDIAC NERVE OF SYMPATHETIC SYSTEI-71:61

INFERIOR CARDIAC NERVE OF SYMPATHETIC SYSTPI-71: 64

SUPERIOR CARDIAC NERVES OF VAGUS-68:34

(DEPRESSOR NERVE) -68:35

INFERIOR CARDIAC RAMI OF THP RECURREINT IERVE-68:37 CARDIAC PLEXUS-72:9 

9. Trachee and tronchi

BRONCHIAL LIMPH GLAINDS-56:52

TRACHEA - $37: 41$

RIFIRCATION OF THE TRACHEA-37:46

RICHT AND LETI BRONCHI-37:47

BRONCHOESOPHAGEAL MUSCLEX $32: 72$

10. Postericr mediastinal cavity and structures within it

POSTERIOR IRDIASTINAL CAVITY-38:21

The following structures are exposed, so far as they are in relation to the posterior mediastinal cavity, by making a longitudinal incision through the posterior wall of the pericardial cavity and reflecting the pericardium. VAGUS IERVE-68:22

RECURREINT NERVE-68:36

ANTERIOR AND POSTERIOR. BRONCHIAL RANI-68:43, 44

ANTERIOR AND POSTERIOR PULMONARY PLEXUSES-68:45, 46 Cf. Thorax, III:3.

OESOPHAGEAL FASI- 68:47

ANTERIOR AID POSTERIOR OESOPHAGEAL PLEXUSES- $68: 48,49$

THORACIC PART OE OESOPEAGUS-32:68

THORACIC AORTA-59:5I

VISCERAI RAHI-49:52

BRONCHIAI ARTERIES $-49: 53$

OESOPEAGEAL ARTERIES-49:54

PERICARDIAC PAIII-49:55

PARIETAL RAIII-49:56

MEDIASTINAL RAII-49:57

SUPERTOR PHPBNIC ARTERIES-49:58

INTERCOSTAL ARTERIES-49:59

THORACIC DUCT-56:25

POSTERIOR MEDIASTINAL LMAPH GLANDS-56:54

IV. Therasic Wall: Posterior Part

1. Thoracic part of the sympathetic nervous system

Exposed by removing the parietal pleura from the posterior part

of the thoracic wall.

SYIPATHETIC TRUNK-71:30

THORACIC GAINGLIA-72:2

RARI CORLIUNICANTES $-68: 72$

GREAT SPLANCHNIC NERVE-72:3

SPIANCHNIC GANGLION-72:4

SIALL SPLAINCHNIC IERVE-72:5

(LOWEST SPLANCHNIC INERVE) $-72: 7$

2. Structures in relation to the internal surface of the posterior thoracic wall

SUBCOSTAL MUSCLES-25:7 Not cmnstant in degree of development.

INTERNAL INTIRCOSTAL INUSCIES-25:6

INTERCOSTAL ARTERIES-49:59

HIGIEST INTERCOSTAL ARTERY $-48: 63$

INTERCOSTAL NERVES-70:1 

INTERCOSPA: Vuf:

AZYGOS VEIN-54:53

HEMIAZYGOS VEIN-54:54

The following veins are variable in their relationship and degree of development:

ACCESSORY HEMIAZYGOS VEIN-54:55

OESOPHAGEAL VEINS-54:59

POSTERIOR BRONCHIAL VEINS-54:60

\section{Deep Structures of the Back}

1. Posterior serrati muscles and the lumbodorsal fascia

For the muscles and related structures external to the posterior serrati muscles, see Superior Extremity, I:3, 4.

For the structures of the back of the neck see Head and Neck, IV:2-4.

SERRATUS POSTERIOR SUPERIOR MUSCLE-23:22

SERRATUS POSTERIOR INFERIOR MUSCLE-23:21

LUWBODORSAL FASCIA-24:5

A longitudinal incision through its posterior layer and a medial displacement of the subjacent sacrospinalis muscle exposes its (anterior layer. A longitudinal incision through this anterior/layer close to its attachment to the tips of the transverse processes and a medial displacement of the lateral margin of the subjacent quadratus lumborum muscle exposes the transversalis fascia.

\section{Intrinsic muscles of the back. 1}

For the corresponding muscles of the neck see Head and Neck, IV:3. SACROSPINALIS MUSCIE-23:25

ILIOCOSTALIS MUSCLE $-23: 26$

Demonstrated by successive lateral eversions of its inferior, middle and superior subdivisions, guarding the nerves and vessels emerging between the iliocostalis and the longissimus dorsi muscles. ILIOCOSTALIS LUMBORUN MUSCLE-23:27

IIIOCOSTALIS DORSI MUSCIE-23;28

ILIOCCSTALIS CERVICIS MUSCLE-23:29 Origin only.

LONGISSIMUS MUSCLE-23:30

LONGISSIMUS DORSI MUSCLE-23:31

LONGISSIMUS CERVICIS MUSCLE-23:32 Origin only. LONGISSIMUS CAPITIS MUSCLE-23:44 Thoracic origin only.

SPINALIS MUSCIE-23:45

SPINALIS DORSI MUSCLE-23:46

SEMISPINALIS MUSCLE $-23: 49$

Exposed by removing the spinalis dorsi muscle and reflecting

the longissimus dorsi muscle laterally.

SEIISPINALIS DORSI MUSCLE-23:50

SEMISPINALIS CERVICIS NUSCLE-23:51 Thoracic portion onlyMULTIFIDUS MUSCLE-23:53

Demonstrated by detaching the semispinalis muscle at its insertion and reflecting it laterally.

1 Nany of the structures indicated in sections 2 to 6 may also ke demonstrated as exposed in a cross section of the posterior thoracic wall made at about the level of the fourth thoracic 

ROTATORES WUSCEE-23:54

Exposed by removing the multifidus muscle, guarding against injury to thoracic and lumbar nerves and vessels. ROTATCEES LONGI IIUSCLE-23:55

RCTATORES BREVES MUSCLES-23:56

The following muscles are not as vell developed in the back as in the neck:

INTERSPINALIS MUSCLES-23:57

INTERTRANSVERII NUSCLES-23:58

INTERTRANSVERSARII MEDIALES MUSCLES $-23: 60$

INTSRTRANS VERSARII I.ATERALES NUSCIES-23:59

\section{Nerves and blood vessels}

\section{POSTERIOR. RAII OF THORACIC NERVES-69:75 \\ LATIRAI CUTANEOUS RAMI-69:76 \\ INEDAI CUIANEOUS RAIII-69:77 \\ POSTERIOR. RANI OF LUIBAR NHPVES-7C:12 \\ HEDIAI RATHS-70:13 \\ LATEEAI RANUS-70:14}

POSTERIOP. RANT OF SACRAL AID CCCCYGEAL IERVES-70:18

POSTERIOR REMI OF INERCOSHAL ARTERIES-49:60

IAUSCULAR RAVI-49:6\%

IEDIAI CUTAITOUS RAII-49:63

IATERAL UUTHIEOUS RAIII-49:64

DORSAL RANI OF THE HIGHEST INTERCOSTAL ARTERY-48:61

DORSAL RAIIUS OF LUIBAR ARTERIES-50:10

DORSAL RAIUUS OF IITPECOSTAL VEINS-54:57

The lumbar veins also have dorsal tributaries from the back comparable to the dorsal rami of the lumbar arteries.

4. Vertebral canal: blooü-vessels and meninges

The contents of the rertebral canal are exposed by cutting through the laminae of the vertebral arches close to the articular processes, dividing the ligamentur flava and removing the posterior wall of the vertebral canal.

LIGAITNA FIAVA-18:40

SUPRASPINOUS LIGAMEIT-18:44

IIVTERSPINOUS IIGAIUNTS-18:43

Arteries supplying the vertebral column:

SPINAL RANUS OF POSTERIOR RARI OF INTERCOSTAL ARTERIES-49:61

SPINAL RAIIUS OF LURBBAR ARTSRTIS-50:II

CAVU: EPIDLRALE $-65: 42$

DURA HATER SPINAIIS-65:40

RILUN DURA: NATRIS SPINALIS-65:11

The following structures are exposed by making a median incision througis the dura, guarding against injury to the subjacent arachnoidea.

CAVUII SUBDURALE-65:43

PIA NATER SPINAIIS-65:54

ARACHNOIDEA SPINALIS-65:44

CAVUH SUBARACHIOIDEALË-65:46

IIGAIIENTUS DENTICULATUN - $05: 55$ 

5. Spinal cord: nervee, blood vessels and surface anatoriv

For the cervical part of the spinal cord see head and Neck, IX:4.

a. Spina? nevves

THORACIC NERVES $-69: 74$

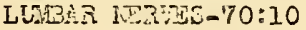

SACFAL NERVES-70:17

COCCYGEAL NERVES-70:17

CAUDA EQQUINA-68:74

ANTERTOR. RCOT-68:67

POSTIRTOR KOOT- $58: 68$

FILIA RADICUIARIA 68:66

SPINAL GAYTLION-68:69

ANTERIOR RANIUS-68:70

POSTERIOR PAMTS- 68:71

RAMUS IENNNGELS - 68:73

Difficult to demonstrate.

In demonstrating the remaining structures of the spinal cord, the spina? nerve trunks are cut, the cord divided transversely at about the level of the first thoracic vertebra, and the cord, and its membranes removed from the vertebral canal.

b. Blood vessels of the spinel cord. Usually difficult to demonsira

SPINAL RAII OF POSTERIOR RAMI OF INTERCOSTAL ARTERIES-49:61

SPINAL RAIII OF LUNBAR ARTERIES-50:II

SPINAL RAIIUS OF ILTOLUMBAR ARTERY $-50: 60$

SPINAL RAIII OF IATERAL SACRAL ARTERY $-50: 63$

INTERNAL SPTNAL VEINS $-55: 2$

POSTERIOR EXTERNAL SPINAL WINS-55:I

ANTERIOR EXTLRNAL SPINAL VEINS-54:70

INTERVERTEBRAL VEINS $-54: 69$

c. Surface anatomy of the spinal cord

THORACIC PART $-58: 23$

LU:BAR PART-58:24

LUUBAR ENLARGENIENT-58:25

NEDULLARY CONE-58.26

VENTRICULUS TERIANALIS-58:28

FILUM TERIIINALE-58:?7

ANTERIOR INDIAN FISSURE-58:29

POSTERIOR IEDIAN SULCUS $-58: 30$

ANTERIOR LATERAL SULCUS-58:3I

POSTERIOR LATERAL SULCUS-58:32

POSTERIOR INTER EDIATE SULCUS-58:33

(ANTERIOR INTERIEDIATE SULCUS)-58:34

FUNICULI OF THE SPINAL CORD-58:45

ANTERIOR FUNICULUS-58:36

LATERAL FUNICULUS-58:37

POSTERIOR. FUNICULUS- $58: 38$

6. Spinal cord: internal structure.

Demonstrated by making transverse sections through the spinal cord at various levels, and in some instances requiring the aid of a hand lens. 



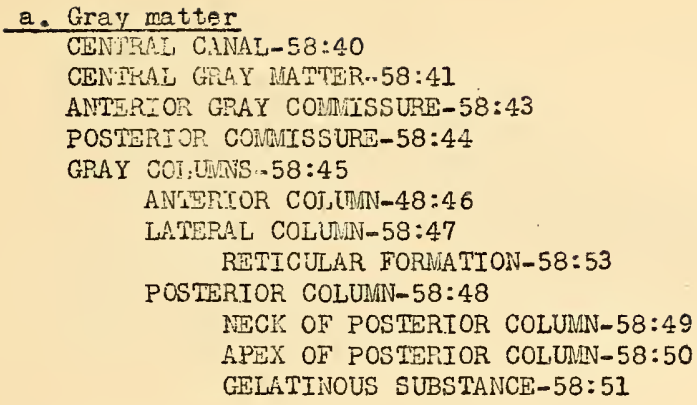

b. White net ter

ANTERTOR WHITE COMMISSURE-58.42

ANTERTOR FUNICUJ_US-58:54

ANTERTOR CEREBPOSPINAL OR PYRAMIDAL F:SICULUS-58:55

LATERAL FUIICUEUS $59: 2$

LATEPAI CEPEBROSPINAL OR PYRAMIDAL FAEICULUS-59:3

CHUABETIOSDTNAL FASICULUS-59:4

POSTERTOR FINICUI,US-59:7

FASICU.UUS GPACIJIS $-59: 8$

FASTUULUS CUNEATUS-59:9

\section{Articulations of the thorax}

1. Sternocostal articulations $-19: 25$

ARTICULAR CAPSUIE-19:26

INTERARTICULAR STERNOCOSTAL LIGAIENT-19:27

RADIATE STERNOCOSTHL LIGANENTS-19:28

NEMBRANE OF STERNUII $19: 29$

COSTOXIPHOID LIGAUENTS-19:30

INTERCHONDRAL ARTICULATIONS-19:34

2. Synchondrosis sternalis $-7: 49$

3. Costovertebral articulations-19:12

a. Capitular articulations-19:13

AnTIOULAR CAPSULES-19:14

RADIATE LIGAMENT OF HEAD OF RIB-19:15

INTERARTICULAR LIGAIENT OF HEAD OF RIB-19:16

b. Coctotransverse articulations-19:17

ARTICULAR CAPSULES-19:I8

LICAMUNT OF TUBERCLE OF RIB $19: 19$

LICAMENT OF INECK OF RIB. 19:20

ANTERIOR COSTOTRANSVERSE JIGAIVENT-19:21

POSTERIOR COSTOTRANSVERSE IIGAMEINT-19:22

LUMBBOCOSTAL LIGAIRENT. 19:23

COSTOTRANS VERSE FORAIEN-I $9: 24$ 

4. Articulations of the rertebra = colum

For the Iigaments in relation to the vertebral arches, see Thorax, $v: 4$.

ANTERIOR LONGITUDINSL LIGAIENT-18:46

POSTERIOR LONGITUDINAI LIGANENT-18:47

INTER IERTEBRAL FIBROCARTILA IES-18:37

The following structures may be demonstrated by dividing the thorax at about the level of the fourth thoracic intervertebral disc, and making incisions through the disc:

ANNULUS FIBROSLS-18:38

NUCLEUS PUPLUSUS-18:39 

$\mathrm{HEADA} D \mathrm{D}$ H $\mathrm{DCK}$

$-\cdots-\cdot-\cdot-\cdots \cdot-\cdot$ 

POSIERIOR AURICITAR VEIN 54:21

OCCIPITAL VEIN-54:2C

3. Scalp: jeeper etructires

a. inuscles

EPICRANIUS MISCIË-24:8

FRONTAL MUSCIE-24:9

PROCERLS IUUSCLE-24:17.

OCCIPITALIS MUSCIE-24:10

AURICUIARIS ANTERIOR NUSCIE-24:20

AURECUIARIS SUPLRIOR NUSCIE-24:21

AURICUIARIS POSTERIOR MUSCLE-2.4:22

GALEA APONEUROTICA-24:42

PERICRANIULi-12:I6

Exposed by dividing the galaa aponeurotica by two incisions,

about $4 \mathrm{~cm}$. in length, intersecting each other at right

argles at the vertex and reflecting the flaps, identifying at the same time the loose areolar connective tissue external to it.

b. I,ymphatics

OCCIPITAL LUSPH GTHNDS-56:35

POSTERIOR AUI:ICUIAF GLANDS-56:36

ANTERIOR AUR:CULAR GIANDS-56:37

4. Auricle or external zar

LOBULE OF THE AURICIE-78:33

TRAGUS-78:46

INCISURA INTERTRAGICA-78:49

INCISIRA ANTERIOR-78:4:

CONCHA OF AURICLE-78:43

CINBA OF CONCHA $-78: 44$

CAYIIY OF CONCHA-78:45

HEIIX-78:35

CRUS HELICIS XY.-78:36

SPINA HELICIS $\times X-78: 37$

CAUDA HELICISXX $-78: 38$

ANTHELIX-78:39

C.T. ATHELICISXX-78:41

FOSSA TRIAIVULARISXX-78:40

(Tubercuivin auriculae) $x x-78: 50$

FOSSA ANTHELIXXX-78:59

EUIINGNTIA CONCHAEXX-78:60

EIIINENTIA SCAPHAFXX-78:6I

EIINENTIA FOSSAE TRIANGULARISXX-78:62

The muscles and ligarients of the external ear-78:67-74- are exposed by removing the skin from the auricle.

II. Intracranial structures in relation to the brain and cranial wall

- Structures exposed by the removal of the calvaria

The calvaria may be removed by: a) making a median longitidinal incision through the galea aponeurotica and pericranium, extending from the glabella to the external occipital protuberance, and reflect ting the two flaps laterally to the level of the temporal lines; 

INTERNAL CAROTID ARTERY $-17: 68$

VERTEBRAL ARTERY-48:21

NIDDLE IEIIINGEAL ARTERY-47:50

\title{
e. Hypoohysis-62:30
}

Isolated for study by detaching the diaphragma sellae and removing the hypophysis from the sella turcica.

ANTERIOR AND POSTERIOR LOBES-62:31, 32

The relations of its lobes may be further examined by dividing the hypophysis in the sagittal plane.

To retain the structure in the floor of the craniurn for later study the cranial cavity may be filled with tow or gauze soaked with preservative fluid, the calvarium replaced and the scalp flaps stitched in position over it.

\section{Structures in the lateral and anterior regions of the neck}

\section{Surface anatomy}

\author{
HYOID BONE-12:10 \\ GREATER CORNUA-12:13 \\ LARYNGEAL PRONIINENCE-36:19 \\ THYREOID CARTILAGE-36:21 \\ CRICOID CARTILAGE $-36: 35$ \\ TRACHEN-37:41 \\ CAROTID TUBERCLE OF THE 6th CERVICAL VERTEBRA-6:42 \\ JUGULAR IOTCH-7:54 \\ CLAVICLE-13:59 \\ MANDIEIE-11:60 Its inferior margin. \\ MASTOID PROCESS-8:78 \\ STERNOCLEIDONASTOID MUSCLE-24:55
}

\section{Regions of the neck}

\author{
ANTERIOR REGIONS OF THE NECY-82:24 \\ SUBIENTAL PRGION-82:25 \\ HYOID REGICN-82:26 \\ SUBHYOID REGION-82:27 \\ LARYIVGEAL REGION-82:28 \\ THYREOID REGION-82:29 \\ SUPRASTERIAL REGION-82:30 \\ JUGULAR FOSSA - 82:31 \\ SUBNAXILLARY FIIAIOIJ-82:32 \\ CAROTID FOSSA-82:33 \\ STERNOCLEIDONASTOID REGION-82:34 \\ LESSER SUPRACLAVICLLAR BOSSA-82:35 \\ LATERAL REGIONS OF THE JIECK-82:36 \\ LARGER SIPRAALAVICULAR FOSSA-82:37 \\ OMOCLAVICULAR TRIANGLE-82:38 \\ POSTERIOR REGIONS OF THE INEK-82:39 \\ NUCHAI REGION $-32: 40$
}

3. Superficial fascia, platysma, veins and cutaneous nerves

Incisions for skin reflection: a) in the middle line from the chin

to the manubrium; b) from the middle of the superior margin of the

manubrium obliquely lipward and backward along the sternocleido- 

mastold musclo to the mastoid process; c) from the middle of the superior narein of the ranuiorium laterally along the clavicle to the acromion.

SUPERFICIAL FASCIA $-23: 36$

PLATYSMA MUSCIE-24:54

The following structures are exposed by reflecting the platysma upward:

EXTERNAL JUGULAR VEIN-54:19

POJTERIOR AURICULAP. VEIN $-54: 21$

ANTERIOR IUGULAR VEIN-54:22

SUPERFICIAL CERVICAL LYPH GLANDS-56:41

LESSEF. DCOIFITAL RERVE-69:10

GREAT AUFICUT:R IERVE-69:21

CUTANEOJS NRTE OF THE NECK-69:14

SUIERIOR RAIII-69:15

INERRIOR PAITT-69:16

SUPRACIAIICULAR. IIERVES-69:17

AITERIOR SUPEACLAVICULAR NERVES-69:18

IMIDILE SUPRACJ AVICUIAR IERVES-69:19

POSTEPIOR SUPRACIAVIUULÁR NERVES-69:20

CERVICAL BRANCH OF THE FACIAI NERVE-67:62

\section{Cervical fascia and sternocieidnmastoid muscle}

CERVICAL FASCIA-24:70

The varicus subdivisions and certain deeper relations of the fascia can as yet not be completely exposed. In the region of the sternum the superficial or investing layer of the cervical fascia divides into two layers and encloses a suprasternal space (sometimes called the space of Burns) which may be exposed by making a transverse incision through the fascia immediately above the sternum and a second incision about $2 \mathrm{~cm}$, in length along the anterior border of each steracleidomastoid muscle, reflecting the fascial flap upwards and demonstrating the areolar tissue, content of the space and the lower parts of the anterior jugular veins and their anastomoses.

STERNOCLEIDOIASTOID MUSCLE-24:55

\section{Posterior triande of the neck.}

The following contents of the posterior triangle of the neck are exposed by carefully removing the cervical iascia, noting its relations to the omohyoid muscle and the chain of deep cervical lymph glands along the posterior margin of the sternocleidomastoid muscle and confining the dissection to the triangle and its two subdivisions.

a. Occipital triangle

CCCIPITAL ARTERY $-47: 22$

TRANS VERSE CERYICAL ARTERY $-48: 67$

OCCIPITAL VIN-54:20

TRANS VERSE CERVICAL VEIINS-54:28

SUPRACLA VICULAR NERVES-69:17-20

ACCESSORY NERVE-68:57

MUSCULAR SAMI OF THE CERVICAL IERVES TO THE TRAPEZIUS AND LEVATOR SCAPULAE MUSCLES.

SUPERIOR DEEP CERVICAL LYMPH GLANDS-56:42 
b. Supraclavicular triangle

This triangle has also been designated the subelavius triangle. Cf. omoclavicular trigone- $82: 38$.

INFERIOR BIIII OF THE ONOHYOID NUSCIE-24:59

PREVERTYBRAL FASCIA-24:7I

The following structures are exposed by removing the prevertebral fascia.

TRANSVERSE CERVICAL ARTERY-48:67

TPANSVERSE SCAPULAR ARTERY-48:60 Slightly inferior to the level of the triangie, strictly speaking.

SUBCEAVIAN ARTERY $-48: 20$ Its third part.

EXTERNAL JUGUIAR VEII-54:19

ANTERIOR JUG.JIAR VEIN-54:22

TRANSVERSE CERVICAL VEINS-54:28

TRANSVERSE SCAPUIAR VEIN-54:25

SUBCLAVIAN VEIN-54:26 Slightly inferior to the level of the triangle, strictly speaking.

INFERIOR DEE? CERVICAL LYMPH CLANDS-56:43

c. Supraclavicu?er part of the brachial plexus-69:25

POSTERIOR THCPAC TC TERVES -69:26

DORSAI, SCA TIIAR NERVI-69:27

LOHG THORACIC NERVE-69:28

ANTERIOR THORACIC NERVES-69:29

SUBCLA VIAN NERVE-69:30

SUPRASCAPUIAR NERVE-69:31

THORACODORSAL NERE $-69: 33$

AXILIARY NERVE-69:34

d. Muscles in floor of posterior triangle

SPLENDIUS CAPITIS IIUSCIE-23:24

LEVATOR SCAPUIAE MUSCIE-23:20

SCALENUS MEDIUS MUSCLE-24:67

SCALENUS POSTERIOR IUSCLE-24:68

\section{Anterior triangle}

The following structures should be dissected with reference to both their continuity throughout the anterior triangle as a whole as well as their relations to its three subdivisions (the submaxillary, carotid and muscular triangles), removing at the same time the cervical fascia but guarding against injury to nerves.

a. Subraxillary or digastric triangle

The following structures may be identified vith very little if any dissection:

SUBMAXILLARY LYNPH GLANDS $-56: 38$

SUBMAXILIARY GLAND-31:11.

EXTERIVAL RAXILIARY ARTERY -47:13

SUBIMENTAL ARTERY ${ }^{X X}-47: 16$

MYLOHYOID RAMUS OF THE INTSRNAL NAXILLARY ARIERY $X X-47: 48$

ANTERIOR FACIAL VIIN-53:70

LINGUALL VEIN ${ }^{2 \pi}-53: 6$

HYPOGLOSSAL NERVE-68:60

MYLOHYOID NERVE-67:32

MYLOHYOID LAUSCLE-24:51

HYOGLOSSUS MUSCLE-32:3 

By makir.g a short vertical slit in the byoglossus muscle between the hypoglossai nerve and the tendon of the digastric muscle the lingual artery may be exposed at a point where it is frequently ligated.

b. Carotid triangle

COMMOIN CAROTID ARTERY-46:59

In determining the relations of the carotid artery to the carotid sheath of the cervical fascia it will be observed that throughout the greater part of their course the structures within the carotid sheath together with cervical part of the sympathetic nerve trunk are strictly speaking internal to the sternocleidomastoid muscle rather than within the carotid triangle, and that their exposure consequently involves a lateral retraction of this muscle. EXTERIVL CAROTID ARTERY $-46: 60$

SUPERIOR THYREOID ARTERY-46:61

HYOID RAMUS $-46: 62$

STERNOCIEIDOMASTOID RAMUS - $46: 63$

SUPERIOR LARYNGEAL ARTERY-46:64

LINGUAL ARTERY $-47: 8$

EXTERNAL MAXJ.LLARY ARTERY $-47: 13$

STHRNOCLEIDO:ASTCID ARTERY-47:21

OCCTPITAL ARTERY-47:22

ASCDNDING PHARYIGEAL ARTERY $-47: 4$

INIERNAL CAROTID ARTERY $-47: 68$

INTERNAL JUGULAR VEIN-52:69

LINGUAL VEIN-53:6

(SUPERIOR THYREOID VEINS) -53:10

CONNON FACIAL VEIN-53:69

ANTERIOR FACIAL VEIN-53:70

POSTERIOR FACIAL VEIN-54:6

HYPOGLOSSAL NERVE-68:60

DESCENDING RANUS-68:61

ANSA HYPOGLOSSI-68:62

THYPEOHYOID RAMLS $-68: 63$

ACCESSORY NERVE-68:57 Its external ramus-68:59

VAGUS NERVE-68:22

SUPERIOR LARYNGEAL NERVE-68:30

IXTERNAL RAMUS-68:31

INTERNAL RANUS-68:32

CERVICAL PART OF THE SYMPATHETIC TRUNK-71:34

SUPERIOR CERVICAI GANGLION-71:35

EXTERNAL CAROTID NERVES-71:45

EXTERNAL CAROTID PLEXUS-71:46

SUPERIOR DEEP CERVICAI LMMPH GLANDS-56:42

LARYNX-36:18 Identified without dissection.

PHARYNX-32:29 Identified without dissection.

GLOMUS CAROTICUM $-38: 30$

c. Muscular triangle

STERNOHYOID MUSCLE $-24: 56$

STERNOTHREOID MUSCLE-24:60

NERVES TO THE STRPNOTHYREOID AND STERNOHYOID MUSCLES

EXTERNAL RAMUS OF THE SUPERIOR LARYNGEAL NERVE-68:31

RECURRENT NERVE-68:36.

The following structufies are identified without dissection: 

LARYNX $-36: 18$

TRACHEA $-37: 41$

THYREOID GLAIND-38:22

OESOPHAGUS $-32: 66$

7. Structures in relation to the anterios median line of the neck

Note the relations of the following structures to the muscular

triangle vith very little, if any, dissection:

a. Suprahyoid region

PLATYSIMA MUSCIE -24:54 Already exposed, III:3.

SUPERFICIAL FESCIA-23:36

ANTERIOR AID POSTERIOR BELLIES OF THE DIGASTRIC MUSCLES-24:48, 49. The submental triangle and its contents are situated between them.

MILOHYOID MUSCLES-24:51 Separated by a raphe.

b. Infrahyoid region

HYOTFIKEOTD IEIMBFANE-36:34

THYREOTD CARTILACE $-36: 21$

CRICOTHYRPOID LTGANENT-35:45

CRICOID CARTIJAGE $-36: 35$

C.RICOTHYREOID NUSCJ $E S=36: 78$

TRACHEA $=37: 42$

ISTHIUS OF 'THXREOID G!AND.38:23

(PYRAIIIDAL LOBE OF THYREOID GLAND) -38:24

INFERIOR THYREOID VEINS-52:52

8. Muscles of the neck: second and thrid layers

DF CASTRIC NUSCLE-24:47

STYLOHYOID MUSCIE-24:50

OROHYOID NUSCLE-24:57

STERNOHYOID IIUSCLE $-24: 56$

STERNOTHYREOID MUSCLE-24:60

THYREOHYOID MUSCIE-24:61

9; Sternoclavicular articulation-19:52

Exposed by dividing the sternal and clavicular heads of the sternocleidonastoid muscle and reflecting the muscle toward its

insertion.

STERNOCLAVICULAR LIGALENT-19:55

INTERCLAVICULAR LIGAIENT-19:57

COSTOCLAVICULAR LIGAINENT-19:56

ARTICULAR CAPSULE-19:53

ARTICULAR DISC-19:54

10. Root of the neck

a. Muscles

ANTERIOR SCALENE IMUSCLE-24:66

MIDDIE SCAIENE NUSCIE-24:67

POSTERIOR SCALENE MUSCLE-24:68

b. Blood vessels and lymphatics

Many of the following structures have already been partly exposed in preceding dissections and are here relisted with more especial 

reference to their relations to the root of the neck. SUBCLA VIAN ARTERY-48:20

VERTEBRAI ARTERY-48:21

INTERNAL MAMNARY ARTEKY $-48: 34$

THYREOCERVICAL TRUNK $=48: 48$

INFERIOR THYREOID ARTERY $-49: 49$

ASCENDING CERVICAL ARTERY-48:55

SIPERFICTAL CERVICAL ARTERY-48:59

TRANS VERSE SCAPULAR ARTERY $-48: 60$

COSTOCERVICAL TRUNK-48:62

HIGHEST INTERCOSTAL ARTERY $-48: 63$

DEEP CERVICAL ARTERY $-48: 66$

TRANSVERSE CERVICAL ARTERY $-48: 67$

RIGHT AND LEFT INNOMINATE VEINS-52:51

INHERIOR THYREOID VIINS $-52: 52$

INFERIOR LARYNGEAL VEIN-52:55

LOWEST THYREOID VEIN $-52: 53$

UNPAIRED THXREOID PLEXUS $-52: 54$

VERTEBRAL VEIN-52:63

DEEP CERVICAL VEIN ${ }^{X K}-52: 64$

INTERNAL JUGULAR VEIN $=52: 69$

INFERIOR BUIB OF THE JUGULAR VEIN-52:70

SUBCLAVIAN VEIN-54:26

THORACOACRONIAL VEIN-54:27

TRANSVERSE CERVICAL VEINS-54:28

THORACIC DUCT-56:25

RIGHT LYMPHATIC DUCT-56:24

c. Nerves

PHRENIC NERVE-69:21

VAGUS NERVE-68:22

CERVICAL SYMPATHETIC TRUNK-71:34 Its lower part.

MIDDLE CERVICAL GANGLION-71:60

INFERIOR CERVICAL GANGLION-71:62

SUPERIOR CARDIAC NERVE-71:59

MIDDLE CARDIAC NERVE-71:61

INFERIOR CARDIAC NERVE-71:64

ANSA SUBCLAVIA-71:63

d. Remaining structures at the root of neck

Structures identified without dissection.

SURMIT OF PLEURA-38:5

TRACHEA-37:41

OESOPHAGUS $-32: 66$

11. Cervical plexus and viscera of themez?

CERVICAL PLEXUS-69:9

The following organs should be left in situ for later reference:

THYROID GLAND-38:22

ISTHMUS $-38: 23$

(PYRAMIDAL IOBE) $-38: 24$

RIGHT AND LEFT LOBES-38:25

(ACCESSORY THYREOID GLANDS)-38:28 Also designated

TRACHEA-37:41 parathyreoid glands. 

TRACHEAL CARTILAGES $-37: 42$

MEIIBRANOUS WALL-37:44

CERVICAL PART OF OESOPHAGUS-32:67

\section{Back of the head and neck}

1. Regions of the back of the head and neck

PARIFTAI, REGION-82:4

OCCIPITAL REGION $-82: 5$

POSTERIOR REGION OF THE NECK-82:39

NUCHAL REGION-82:40

FOVEA NUCHAE-83:1

2. Fascia, superficial nerves and vessels

Incisions for skin reflection: a) from the external occipital protuberance to the spine of the vertebra prominens; $b$ ) from the spine of the vertebra prominens laterally on each side to the medial border of the acromion; c) from the external occipital prptuberance laterally on each side for about $6 \mathrm{~cm}$.

SUPERFICIAI, FASCIA-23:36

GREAT OCCIPITAL NERVE-69:6

SMALL OCCIPITAL NERVE-69:10

OCCIPITAL VEIN-54:20

(THIRD OCCIPITAJ, NERVE) $-69: 7$

POSTERIOR RAIII OF CERVICAL IERVSS IV-VIII-69:2

POSTERIOR RAIUS OF GREAT AURICUIAAR NERVE-69:12

The following structures may be exposed in the suboccipital

triangle:

FIRET. TERVICAI NERVE-69:1

VERTEBRAL ARTERY-48:21 Its third part.

3. Muscles in relation to the back of the neck

TRAPEZIUS INUSCIE-23:15 - Its cervical part only. LEVATOR SCAPULAE IAUSCLE-23:20

Exposed by dividing the trapezius muscle at its origin from the superior nuchal line and external occipital protuberance, and cutting through the muscle about $1 \mathrm{~cm}$. from the cervical vertebral spines and reflecting the cervical part of the muscle laterally, guarding against injury to underlying structures.

The following structures are either internal to the levator scapulae muscle or in relation to the superior margin of the scapula.

DESCENDING RANUS OF THE TRANSVERSE CERVICAL ARTERY-48:69

DORSAL SCAPULAR NERVE-69:27

INEERIOR BEILY OF ONOHYOID NUSCLE-24:59

TRANS VERSE SCAPULAR ARTERY-48:60

SUPRASCAPUTAR NERVE- $69: 31$

RHONBOIDEUS MTNOR MUSCLE-23:19 Its origin only.

In demonstrating the following structures the rhomboideus minor muscle should be detached at its origin and reflected laterally. FASCIA NUCHAS-24:6 

In demonstrating the folloving two muscles the serratus posterior superior muscle shou? lateraily.

SPLEIIUS CAPITIS I.USCLE-23:24

SPLEIIUS CERVICIS NUSCLT-23:23

The following muscles are exposed by dividing the attachments of the splenius capitis and splenius cervicis muscies close to the spines of the vertebrae and reflecting the muscles.

ILIOCOSTAIIS CERVICIS MUSCLE-23:29

LONGISSTMUS CAPITIS MUSCLE-23:44

SPINALIS CERVICIS MUSCIE-23:47

SPINLAIS CAPIIIS IVUSCTE-23:48

In demorstrating the following two muscles the longissimus capitis should be detached at its origin and reflected toward its insertion.

SEMISPINAITS CERVICIS LUSCLE-23:51

SEMISEINILIS CAPITIS MUSCIE-23:52

MULTIFIDUS MUSCLE-23:53

Exposed by detaching the semispinalis capitis muscle from the tiansverse processes of the cervical vertebrae and reflecting tive muscle icward its insertion. Guard the vessels and nerves internal to the muscle.

ROTATERES MUSC:JES-23:54

mposed by removing the multifidus muscle.

ROIANFRES IONGI MUCLES-23:56

ROIATEFES BREVES MUSCLPS-23:57

INTERSPINNATS NUSCLES-23:58

RECTUS CRPTTHS POSTERICK NAJOR MUSCIE-23:64

RECIUS CAPITIS POSTERTOR MINOR MUSCLE-24:I

OBLIQUUS CAPINIS SUFERIOR MUSCLE $-24: 3$

OBLIQUUS CAPITIS INFERIOR MUSCLE-24:4

The following structures are in relation to the suboccipital space or triangle formed by rectus capitis posterior major and the oblique capitis superior and inferior muscles. SUBOCCIPIIAT, INRVE-69:5 Its posterior ramus. VERTEBRA A ARTERY-48:21 Its third part only. POSTERIOR ARCH OF ATLAS-6:59

4. Deeper blood vessels and nerves of the back of the neck

For the more superficial vessels and nerves see $I: 2 \mathrm{c}$.

OCCIPITAL ARTERY $-47: 22$ IULSULAR RAMI XX $-47: 25$

RAIUS DESCENDENS ${ }^{x x}-47: 26$

WASTOID RANUS $x \times=47: 23$

AURJ.CU:AR RALUS $x x_{-47: 24}$

OCCIPITAL RAIITXX $\times 47: 29$

ASCE:VDING CERVICAL APTERY-48:55

DEEP CERVICAL ARTERY $-48: 66$

OCCIPITAL, VEIN..54:20 IASTOTD ENIISSARY VEIN-53:35

DEEP CERVICAL VEIN-52:64

POSTERIOR RANI OF CERVICAL NERVES-69:2

IIEDIAL PAIT-69:3

LATERAL RAMI-69:4 

INTRAORBITAE REGION-82:20

BUCCAL REGION-82:19

ZYGOIATIC REGICN-82:20

PATROTIDEOAASSETERIC REGIOI- $82: 21$

RERROHA NDIBULAR FOSSA-82:22

3. Fascia and parotid Fland

Inciscions for skin reflection: a) median longiturinal from the

forehead to the tip of the chin; b) from the anterior median

line transversely at the level of the ring palpebrarum, encirc-

ling the $e: 0$, and extending posteriorly to the ear; c) transversely from the angle of the nouth to the posterior border of the raizus of the randible.

PAROIID GLAND-31:13

Exposec by removing the parotideorasseteric fascia.

RETRONAIDIBULAR PRCCESS-31:14

ACCESSCRY PAROTID GLAID-31:15

PAROTI) JUC:-31:16

4. Superficial nerves of the face

ANTERIOR RALUS OF THE CRGAT AUPICULAR NERVYXX-69:13

Branches of the facial nerve:

Exposed by carefully rewoving the parotid gland, a part at

a time. The exit of the facial nerve from the stylorastoid

foramen is exposed by cutting away (with saw and chisel) the

free projecting part of the mastoid process, guarding

against injury to tine posterior auricular nerve.

PAROTID PLEXUS-67:57

TEIPORAL RAIT- $67: 58$

ZYCOHATIC RAII-67:59

BUCCAL RAMII-67:60

MARCINAL IHANDIBULAR RANUS - 67:61

DIGASTRIC RAIIUS-67:54

STILOHYOID RAIUU - $67: 55$

Branches of the opthalmic division of the trigeminal nerve: SUPRAOREITAL IERVE-66:20

FRONTAL KAIUUS-66:21 Of the frontal nerve

SUPRATROCILEAP. NRRVE-65:22

A.TERTOR HIASAL RAII OF THE MASOCILIARY IERVE

SUPERTOR AND INFERIOR PALPEBRAL RAIII OF THE IMFRATROCHLFAR. SWRVEXX $-66: 34,35$

Branches of the maxillary division of the trigeminal nerve: ZYGOARATCOTEIPORAL RAIUS OF THE ZYSOMATIC NEFVE-66:41 ZYGOISATICOFACIAL RALUS OF THE ZYGOIATIC VERVE-66:42 INFERIOP. PALPEBRAL RAII OF THE INTRAORBIDAL NGRVE-66:52 EXTERIAL INSAL RAHI OF THE INJPAORבITAL ITRVE-66:53 SUPERIOR IABIAL RAII OF THE INTRAORBITAL NMRVE-65:55

Branches of the mandibular division of the trigeminal nerve: BUCCINATOR IRRVE-67:13

Way be identified at this sta of the dissection through its anastomoses with the facial nerve. AURICULOTEMPORAL NERVE-67:-

IEETAL NER:D-67:33 

5. Superficial blood vessels of the face

Branches of the external carotid artery:

SUPERFICIAL TEIAPORAL ARTERY $-47: 36$

PAROTID RAMI $-47: 37$

TRANS VERSE ARTERY OF FACE $-47: 38$

ANTERIOR AURICULAR RAMI-47:39

ZYGONATICOORBITAL ARTERY $=47: 40$

MIDDLE TENPORAL ARTERY-47:4I

INIERNAL MAXILLARY ARTERY $-47: 44$

Its origin only.

EXTERNAL MAXILLARY ARTERY $-47: 13$

INFERIOR LABIAL ARTERY-47:18

SUPERIOR LABIAL ARTERY-47:19

ANGULAR ARTERY $-47: 20$

POSTERIOR FACIAL VEIN AND ITS TRIBUTARIES-54:6-9, 13, 14

ANTERIOR FACIAL VEIN AND ITS TRIBUTARIES-53:70-77, 54:I-5

6. Muscles of the face and front of head

PLATYSMA MUSCLE-24:54

FRONTALIS MUSCLE-24:9

PROCERUS MUSCLE-2, $4: 1]$

ORBICULARIS OCULI MUSCLE-24:16

PARS PALPEBRALIS $-24: 17$

PARS ORIBTALIS-24:18

PARS LACRIMALIS -24:I9

NASALIS MUSCLE-24:12

PARS TRANSVERSA-24:13

PARS ALARIS-24:I4

DEPRESSOR SEPTI NASI MUSCLE-24:15

ORBICULARIS ORIS MUSCLE-24:23

QUADRATUS LABII SUPERIORIS MUSCLE-24:28

CAPUT ZYGOMATICUM-24:29

CAPUI INFRAORBITALE-24:30

CAPUT ANGULARE-24:3I

ZYGOMATIC MUSCLE-24:27

RISORIUS MUSCLI $-24: 26$

TRIANGULARIS MUSCLE-24:24

QUADRATUS LABII INFERIORIS MUSCLE-24:32

CANINUS MUSCLE-24:33

BUCCINATOR MUSCLE-24:34

BUCCOPHARYNGEAL FASCIA-24:43

INCISIVI LABII SUPERIORIS AND INFERIORIS MUSCLES-24:35, 36

VI. Structures in relation to the temporal and infratemporal fossae

1. Fascia, muscles and vessels

TEMPORAL FASCIA-24:45

ZYGOMATIC AND TEMPORAL RAMI OF THE FACIAT NERVE-67:59. 58

ZYGOIIATICOFACIAL AND ZYGOIATICOTEMPORAL RAMI OF THE ZYGONATIC

IERVE-66:42, 41

MIDDLE TEMPORAL ARTERY-47:4I

MASSETER MUSCLE-24:38

The following nerve and artery may be exposed as they pass through

the mandibular notch by detaching the temporal fascia from the 

zygomatic arck, with a saw and bone forceps dividing the zygomatic arch immediately anterior and posterior to the origin of the masseter muscle (the anterior sav-cut being made obliquely downvard and anteriorly connecting the anterior ends of the superior and inferior margins of the arch), and carefully reflecting the detached segrent of the zygomatic arch and masseter muscle (the dissection may be complicated by a union of the masseter and temporal muscles). MASSETER NERVE-67:9

MASSETERIC ARTERY $-47: 54$

TEMPORAL NUSCLE-24:39

Exposed by dividing the masseteric nerve and artery and completing the reflection of the masseter muscle toward its insertion.

The deeper structures of the temporal fossa are demonstrated by removing the coronoid process of the mandible by a cut extending from the middle of the incisur: mandibulae downward and anteriorly to the junction of the ramus with the body of the manditie (making the incision partially with a saw and completing the division with a bone forceps), reflecting the coron-id process and the attached temporal muscle upvard (guarding at the same time against cutting the buccinator nerve), and with the handle of a scalpel detaching the deeper porticn of the temporal muscle at its origin.

ANTERIOR AND POSTERIOR DEEP TEMPORAL NERVES-67:11, 12 ANTERIOR AND POSTERIOR DEEP TEMPORAL ARTERIES ${ }^{x \times}-47: 56,55$ NEDIAN TEINPORAL ARTERY $-47: 41$

ZYGOMATICOTENPORAL BRANCH OF THE ZYGOMATIC NERVEXX-66:41

The following structures in the infratemporal fossa are more fully exposed by removing a segment of the ramus of the randible. To this end two incisions ma be made, one through the neck of the condyloid process of the mandible and a second transversely through the ramus of the mandible immediately superior to the level of the mandibular foramen (locating the level of the foramen by inserting the hand of a scalpel between the ramus and the subjacent structures and carrying it downwards until its progress is arrested by the vessels and nerves entering the foramen). In the case of both incisions the cut should be maje through the lateral table of the bone with a saw and the incision completed with a bone forceps; the isolated segment of the mandibular ramus is renoved and the subjacent nerves, vessels and muscles exposed.

EXTERNAL PTERYGOID MUSCLE-24:40

INTERNAL PTERYGOID MUSCLE-24:41

BUCCINATOR MUSCLE-24:34

BUTCCOPHARYNGEAL FASCIA-24:43

PTERYGOINANDIBULAR RAPLE- $32: 52$

INTERNAL NAXILLARY ARTERY $-47: 44 \times x$ Its first and second parts

DEEP AURICULAR ARTERYXX $47: 45$ Its origin only.

ANTERIOR TYNPANIC ARTERYXX-47:46 Its origin only

INFERIOR ALVEOLAR ARTERY $-47: 47$

WYLOHYOID RAMUS $-47: 48$

MIDDLE IENINGEAL ARTERY-47:50

(ACCESSORY RENIGLAL RANUS) $-47: 51$

MASSETERIC ARTERY $-47: 54$

POSIFRIOR AND ANIYRIOR DGEP TEMIPORLL ARTRRY $-47: 55,56$ 

PIERYGOID FW: $I^{2 *}-47: 57$

BÜCCIIHATOR ARTERYXX $-47: 58$

POSTERIOR SUPERIOR ALVEOLAR ARTERY $-47: 59$

The following tributaries of the posterior facial vein are

seldom well enough preserved to be satisfactorily damanstraten by dissection:

ARTICULAR MANDIBULAR VEINSXX $-54: 10$

STYLONASTOID VEINXX $-54: 12$

PTERY JOID PLEXUS54:13

TRANSVERSE FACIAL VEINRX $-54: 13$

\section{Nendibular articulation-19:35}

ARTICULAR CAPSULE-19:36

TIMPORAIANDIBULAR LIGAIENT-19:38

SPHENOMAIFIBULAR LIGAIENT-19:39

STYLOIANDIBTLAR LIGAIENT-19:40

ARIICULAR DISC-19:37

Exposed by removing the temporomandibular ligament.

3. Nerves

The demonstration of the following nerves is completed by disarticulating the condyloid process and reflecting it together with the external pterygoid muscle anteriorly, guarding at the same tine against cutting the auriculotemporal nerve. MANDIBULAR NERVE-67:6

SPINOSUS NERVE- $67: 7$

MASTICATOR IERVE-67:8

MASSFTERIC NERVE-67:8

ANTERIOR AND POSTERIOR DEEP TEMPORAI NERVES-67:11, 12 BUCCINATOR NERVE-67:13

EATERNAL PTERYCOID IERVE-67:14

INTERNAL PTERYGOID IERVE-67:15

AURICULOTEMPORAL NERVE-67:16

MERVE OF THE EXTERRAL AUDITORY IEATUSXX $-67: 17$

RANUS TO THE TYPANIC IEIBRANEXX-67::8

IINGUAL NERV-67:23

INFERIOR ALVEOIAR NERVE-67:32

DYLOHYOID NERVE-67:32

CHORDA TIPPANI-67:64

\section{Vandibular canal-12:3}

Exposed by removing (by means of a sam, chisel and bone forceps)

the outer compact layer of the mandible.

IINERIOR ALVEOLAR ARTSRY $-47: 47$

MYLOHYOID RAMUS-47:48

MEIVTAL ARTERY $-47: 49$

INETRIOR ALVEOLAR IERVE-67:28

INEERIOR DENTAL PIEXUS-67:29

INETRIOR. DEINTAL FAIT-67:29

INEERIOR GINGIVAL RAME-67:31

MYLOHYOID NERVE-67:32

NATAL NERV-67:33

INITIAL RAII-67:33

1.ENTAL RAII-67:34

INNERIOR IABIAI RAII-67:35 



\section{VIT. Submaxillary region.}

1. Superficial structures in the submaxillary region

With the exception of the following structures the more superficial structures in this region have already keen listed in connection with the submaxillary or digastric triangle, III:6a. DIFASTRIC MUSCLE-24:47-49

STYLOHYOID MUSCLE-24:50

SUBMAXILLARY GLAND-31:11 Its superficial part only.

\section{Deeper structures in the submaxillary region}

1IYOHYOID MUSCLE-24:51

Exposed by dividing the anterior belly of the digastric muscle near its attachment to the mandible, sawing through the mandible slightly lateral to the median plane on each side ( $=0$ as to leave intact the attachments of the geniohyoid and genioglossus muscles), and everting the inferior border of the lateral part of the mandible.

IINGUAL NERVE-67:23

Exposed by dividing the mylohyoid muscle slightly below its origin from the mylohyoid iine of the mandible and along the median raphe, and reilecting the muscle dowward over the hyoid bone, guarding at the same time against cutting the mucous membrane of the mouth.

SUBIINGUAL NERVEXX-67:26

LINGLAL RAIII XX-67:27

HYPOGLOSSAL INRVE $-68: 60$

LINGUAL RAIIT $-68: 64$

SUBMAXILIARY GANGLION-67:43

CONMUNICATING RANI UTTH THE IINGUAL NERVE-67:44

SUBIIAXILIARY PAIII- $67: 45$

GI.SSOPHARYNGIAL NERVE-68:8

SUBMAXILIARY GLAND-31:11 Its deep part.

SUBIAXILLARY DUCT-31:12

SUBLINGUAL GLAND-3I:8

IFAJOR AND MINOR SUBLINGUAL DUCTS-31:9, 10

HYOGLOSSUS MUSCLE- $32: 3$

STYLOGLOSSUS MUSCLE-32:5

CHONDROUI,OSSUS MUSCLEXX-32:4

CENIOGLOSSUS IHUSCLE-32:2

GENIOHYOID HUSCLF-24:52

LINGUAL ARTERY $-47: 8$

Exposed by detaching the hyoglossus muscle from the hyoid

bone and reflecting it upward

DORSAL RAII OF THE TONGUE $X X 447: 11$

SUBLINGUAL ARTERYXX-47:10

DEEP ARTERY OF THE TONGUE $X x_{-}-4: 12$

LINGUAL VIIN-53:6

STILOHYOID LIGAINET-18:54

VIII. Structures in relation to the deeper regions of the neck and base of the cranium

1. Otic ganglion, tensor veli palatini, stylopharvigeus muscles 

immediately inferior to their ortgins and carefully displacing the mandibular nerve.

Roots:

A SHORT RCOT FROM THE MANDIBULAR NERVE $X X$

A LONG ROCT, THE LESSEZ SUPERFICIAL PETROSAL NERVEXX$67: 37$

A SYMPATHETIC ROOT FROM THE PLEXUS OF THE MIDDLE MENINGEAL ARTERYXX

Branches of distribution:

TENSOR VELI PALATINI N.RVEXX $-67: 38$

TENSOR TYMPANI INERVEXX-67:39

Communicating rami:

ANASTONOTIC RAIUS WITH THE SPINOUS NERVE $\times X-67: 40$

ANASTONOTIC RAIUS WITH THE AURICULOTEMPORAL NERVE $\mathrm{XX}$

$67: 41$

ANASTONOTIC RAEUS WITH THE CHORDA TYMPANIXX-67:42

TENSOR V:LI PALATINI MUSCLE-32:25

Expused by detaching the internal pterygoid musclo from the posterior border of the lateral lamina of the pterygoid process-8:61

STYLOPHARYIGSUS MUSCLS-32:32

Exposed by dividing the posterior belly of the digastric muscle near its origin and reflecting it toward its attachment to the hyoid bone, cutting through the external carotid artery just inferior to its termination, dividing the postericr auricular and occipital arteries at their origins and displacing the externil carotid artery anteriorly (guarding against injury to the glossopharyngeal nerve).

2. Blood vessels

INTERNAL CAROTID ARTERY $-47: 68$

In completing its exposure the base of the styloid process may be divided (with a bone forceps) and the styloid process together with the attached muscles reflected downward and anteriorly. The correlation of the structures at the base of the cianium with the structures previously exposed in the floor of the cranium may be facilitated by removing the calvarium (guarding, however, against drying of the cranial floor).

In demonstrating the superior portion of the cervical part of the internal carotid artery, the pharyngeal rami of the vagus nerve should first be securad and the following four nerves identified in the interval between the intermal jugular vein,-namely, the glossopharyngeal, vagus, accessory and hyphglossal nerves.

ASCENDING PHARYNGEAL ARTERYXX $-47: 4$

ASCENDING PALATINE ARTERYXX $-47: 14$

TONSILLAR RAIUS OF THE EXTEFNAL INAXILIARY ARTERYXX $-47: 15$

INTERIAL JUGULAR. VEIN-52:69

SUPERIOR BULB OF THE JUGULAR VEIN-52:70

LINCUAL VEIN $-53: 6$

(SUPERIOR THYREOID VEINS) $-53: 10$

CONION FACIAL VEIN-53:69

By slitting open the inferior part of the internal jugular vein the valve situated near the termination of the vein may be demonstrated. 

GLOSSOPHARYNGAL NERVE-68:8

LINGUAI, RANI ${ }^{\mathrm{XX}}-68: 21$ Their origin only.

TONSILLAR RALI XX-68:20

STYLOPHARYNGEAL RAiHU $\times x_{-68: 19}$

PHARYNGEAL RAII $\mathrm{xx}-68: 13$

SUPERIOR GANGLION- $58: 9$

PETROUS CANGLION-68:10

TYHPANIC INERVE-68:11

The following nerve in the middle cranial fossa

is in relationship with the tympanic nerve:

VA.GUS INRVE-68:22

LESSER SUPERFICIAL PETROSAL IERVE-67:37

GANGLICN JUGULARE-68:23

GANGLION NODOSUM-68:24

The following rami cannot be satisfactorily demonstrated in an ordinary dissection.

1/ENINGGAL RAEIUSXX-68:25

AURICULAR RANUS $x \mathrm{x}-68: 26$

ANASTOMOTIC RAMUS WITH THE GLOSSOPHARYNGEAL IERVIXX

Review the following rami:

PHARYNGEAL RAII- $58: 28$

SUPERIOR IARYNGEAL IERVE AND ITS RAII-68:3n-33

SUPERIOR CARDIAC RAIII-68:34

(DEPRESSOR. IERVE) $-68: 35$

RECURREITT INRVE-68:36

ACCESSORY NERVE-68:57

INTERINAL RANISTX $-68: 58$

EXTERIAL RAMUS-68:59

HYPOGLOSSAL NERVE-68:50

The demonstration of its exit from the hypoglossal canal is

facilitated by dividing the internal jugular vein $5 \mathrm{~cm}$, below

the base of the skull and reflecting it upward.

The following rami have already been exposed in preceding

dissections:

RAIIS DESCENDENS-68:61

ANSA HYPOGLOSSI-68:62

THYREOFYOID RAIJUS-68:63

LINGUAI, RAIII-68:64

4. Simpathetic trunk

CERVICAL PART OF THE SYMPATHETIC TRUNK-71:34

SUPERIOR CERIICAI GANGLION-71:35

JUGULAR NERVE XX-71:36

INTERINAL CAROTID NRRVE XX $71: 37$

INTERIAL CAROTID PLEXUSXX $-71: 38$

EXTERIAL CAROTID IERVE ${ }^{\mathrm{KX}}-71: 45$

EXTERIAL CAROTID PLEXUSXX -71:46

IARYNGOPIARYNGEAL RAIIXX $-71: 57$

SUPGRIOR CARDIAC IWRVE-71:59

IIDDLE CERVICAL GANGLION-71:60

INFERIOR CERVICAL GANGLION-71:62

The remaining rami and plexuses of the cervical part of the

sympathetic system are indicated in $-71: 47-54,55,58,65-68$.

RLCTUS CAPITIS LATERALIS MUSCLFX $-24: 2$ 

IX. Structures in relation to the cervical part of the vertebral column and the posterior dert of the base of the skull

The head and neck may be divided into anterior and posterior parts by: a) cutting the nerves and vessels of the neck at the level of the first rib and forcibly displacing these structures together with the oesophagus and trachea anteriorly, a:ay from the cervical vertebrae and exposing the periosteum investing the base of the shull between the pharynx and prevertebral muscles; b) making a transverse incision through this thick periosteum and exposing the pars basilaris of the occipital bone; c) resting the floor of the cranium upon the end of a wooden block and with a chisel and rallet dividing the pars basilanis along the line of the preceding incision (directing the chisel as nearly as possible at right angles to the plane of the bone; ; d) making two saw-cuts through the skull, one on each side, beginning at a point $2 \mathrm{~cm}$. posterior to the mastoid process and extending obliquely anteromedially to a point immediately posterior to the iugular foramen; e) with a chisel comp.eting the division of the base of the skuli by an incision on each side uniting the end of the preceding chisel-cut (c) with the adjacent end of the saw-cut (the incision in each case passing medial and posterior to the jugular ioraren); f) dividing any remaining intervening soft perts and completing the separation of the anterior and posterior parts of the head and neck. The hypoflossal nerve would be divided close to the base of the :kuIl and superior to the ganglion nodosum of the vagus nerve, but all other ce-ebral nerves should remain intact and be carried iway with the anterior part of the skull.

1. Muscles, nerves and blood vessels

RECTUS CAFTTIS LATERALIS MUSCLEX $-24: 2$ Previously listed in

Section $\mathrm{X}: 4$.

RECTUS CAPIRIS ANTERIOR MUSCLER $-24: 65$

LONGUS CAPITIS HUSCIA ${ }^{x \times}-24: 64$

LONGUS COLLI NUUSCLEXX $-24: 63$

ANDERIOR, IIDDIE AND POSTERIOR SCALEN MUSCLES-24:66-68 Their attachments only.

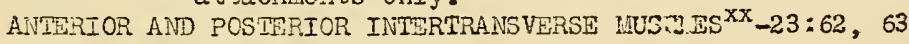

CERVICAL IERVES, I-VIII-69:1

Exposed by removing the prevertebral and scalene muscles. ANIERIOR RAMI-69:8

POSTERICR RAIRI-69:2

VERTEBRAL ARTYRY-48:21

Exposed by removing the intertransverse muscles, the rectus capitis lateralis, the obliquus capitis superior and the obliquus canitis inferior muscles, and with a bone forceps cutting awa the anterior tucercles and costal portions of the transverse processes of the tiird to sixth cervical vertebral. SPI "IAL RAIITX $-48: 22$

VERTEBRAL VEIIT-52:53

2. Articulations of the cervical vertebrae ITI-VII

INTERVRTEBRAI, FIBROCARTILAGES-18:37

FIBROUS RINC-1.8:38

NUCLEUS PUIPOSUS- $18: 38$

LIGAIENTA FLAVA $-28: 40$

ARTICULAR CAPSUEDS-18:41 

INTERTRANSVERE LIGAFIITG $-18: 42$ Not well developed in the reck. INTERSPINOUS LICAMGINTS-18:43

IICADENITH NUUHA-13:45

ANIERIOR LOIGIMUINAE LIGAIENT-18:40

POSTERIOR LONGITUDIML LIGAMENT- $8: 47$

3. Articulations of the epistrofineus, atlas and occipital bone

ATLAN IOO IP TIEL APITUULATION-19:I

ARTICUIAR CAPSUJE-19:2

ANTERTCR ATI, NTOOCIPPITAL NEMBRANE-19:3

POSTERIOR ATLANTOOCTPPITAL IEMBRAIE-19:4

ATLANTCEPISTROPHEAL ARTICUIATION-19:5

ARTICUIAB CAPSUL,-19:6

TCTOFII, MENPFAIE-19:11

Femontrated by removing (with a bone forceps) the posterior arctes of the atias and epistropheus, raking a sat-cut on each side of the occipital bone extending from just posterior to the jugular process and occipital condyie to the foramen magnum, detaching the squamous portion of the cecipital bone and renoving the exposed portion of the dura mater.

CRUCIATE LIGAIEN OF ATIAS-I 3:10

Expcsed by detaching the tectorial membrane from the efietrophe us and reflecting it upvard.

TRANSVERSE ILGAIENA OF THE ATLSS-19:9

ALAR LIGAMENTS- I9:7

Demonstrated by detashing the vertical part of the cruciate, ligament at its superior attachment to the occipital bone and reflectiog it dewnward.

AFICAL LICARNN OF THE DEIS-13:8

4. Cervical portion of the vertebral canal and spinal cord

The contents of the cervical portion of the vertebral canal may bo exposed by cuiting avay all the muscles still remaining attached to the spincus processes and arches of the cervical vertebrae and removing the laminae of the vertebral arches. For the meninges and related siructares, see Thorax, $\bar{v}: 4$.

CERVTCAJ, RERVES-69:1

AIVTERTCR ROOTS $-68: 67$

POSTEPIOP. ROOTS- 68:68

SPINAI: CANC],IA. $68: 69$

ANIERIOF RAIII - 68:70

POSTWRIOR RAMI-68:71

SPINAL FAIII OF THT VERTEBRAL ARTEPY-48:22

POSTERIOR SPINAL ARTERY $-48: 23$

ANTEPIOR SPINAL ARTERY $-48: 24$

CERVICAL PART OF SPTNAI CORE $-58: 21$

CERVICAL ENLARGEIENT-58:22

For surface anatoray and internal structure of the Spinal cord see Thorax, $V: 5$.

X. Remaining structures in the anterior part of the head and neck

See Section IX for division of the head and neck into anterior and posterior parts. 

1. Pharynx $-32: 29,4:: 2$

a. Puscles and fascia of the pharynx

PTEPIGORANDIBULAR PAPIE-32:52

TURICA NUSCULARIS OF THE PHARYNX-32:50

CONSTRICFOR PHARYNGEUS INYERIOR MUSCLE-32:62-64

CONSTRICTOR AHARYNGEUS MEDIUS MUSCIE-32:59-61

CONSTRICTOR PHARYNGEUS SUPERIOR-32:53-57

Expoced by dividing the pterygoideus internus muscle

transversely at its middle and reflecting the two ends

toward their origin and insertion, guarding against cut-

FASCIA PHARTNGOBASIIARIS-32:44

ting the tensor veli palatini muscle.

b. Cavity of tte rharynx-32:3n

Exposed oy raing tive following incisions: a) longitudinality in the middle line throughout the entire extent of the posterior wall of the pharynx; b) from the superior extremity of the preceding incision. transversely through the fascia pharyngobasilaris, ciose to the base of the craniun and extending laterally as far as the cartilage of the Sustachian tube.

The icllowing structures mey be identified by inspection:

PAPS NASAIIS-32:22

FORIIX PHSRYIVIS-32:37

PHARYNCEAT, OPENTNG OF THE EUSTACHYAN TUBE-32:35

AITERTOR LIF-32:36

FSTIRIOR LIP-32:37

TORUS TUBARIUS-32:38

SATPINGOPHARVNGEAL FOLD-32:39

PHARTNCEAJ, RECESS $-32: 40$

PHARYIGLAL TONSII, $32: 47$

TONSITISAR CRYPTS $-32: 48$

(Pharyngeal bursa) $-32: 41$

SOFI PAIATE-30:41

LVUIA-32:13

PARS ORAIIS $-32,33$

GLOSSOPALATIIE ARCH-32:15

PHARYYCPALATINE ARCH-32::6

IATERHI GIOSSOEPIGLOTIIC FOLD-37:27

MEDIAN GLOSSORPIGLOTIC FOLD-37:26

EPIGLOTIIC VAIIICULA-37:12

PARS LARYNGIS $-32: 34$

ARYEPIGIOTTIC FCLD-37:28

CPENING INTO THE LARYIX $-37: 13$

PERIFORII RECESS-32:42

FOLD OF TE IARYNGAL NERVE-37:29

Looking anteriorly from the nasal part of the phar:mx the following are visible in relation to the posterior part of the rasal cavity: NASAL SEPTUN $-35: 39$ INASOPHARYNGEAL IIEATUS-35:59

INFTPIOR NASAI MEATUE-35:5T

ITDDJE IJASAL IEATUS-35:55

INFERIOP NASAL CONCHA-35:\%8

MIDDLE IASAL CONUHA-35:47 

2. Mouth and fauces

To facilitate the demonstration of the following structures the anterior part of the hoad and neck may be divided into two lateral halves by making the following incisions: a) with a knife dividing the uvtila and soft palate in the meaian sagittal plane; b) in a similar manner dividing the cartilaginous part of the nose as far as the nass.l bone as nearly as possible in the mid-sagittal plane, (before raing this incision it should be ascertained whether the nasal sepitum deviates to eitiner the right or left of the mid-plane, and if sc, making the cut through the cartilage close to concave side of the septum and thus guarding against cutting the septum itself); c) witin a saw cutting through the floor of the anterior part of the skuIl, beginning posteriorly and sawing forward making the cuit pass through the hard palate and root of the nose just lateral $\div 0$ the nEsal septum and, in line with preceding incision, through the ce: ililaginous part of the nose; d) with a knife dividing the tongue an soft structure in the floor of the mouth, the pharyin, larynx, trachea and any other remaining soft structure in the median sagittal plane; e) completing the division of saming through the anterior part of the mandible in the same plane.

a. General chametorigtics of the oral cavity

ChETK-30:29

FAT BODY OF TLE CHEEKXY-30:30

VESIIBULE OF TH MOUTH-30:31

WOUTH CAVITY PPOPRR-30:32

ORAL FISSURF-30:33

LIPS $-30: 3 \wedge-36$

IABIAL CONNITSURE $-30: 37$

ANGLES OF THE MOUIH-30:38

PAIATE-30:39

FARD PAIATE $-30: 40$

SOFT PAIAATE-30:41

RAPHE OF THE PAIATT-30:42

b. Mucous membrane of the mouth $-30: 43$

FRENULU OF THE UPPER AND LOWER LIPS-30:44, 45

GUI $-30: 46$

SUBLINGUAL CARURCTE-30:47

SUBLINGUAL FOLD-30:48

TRANSVEREE PATATINE FOLDS $-30: 49$

INCISOR PAPILIA- $30: 50$

c. Glands of the mouth-31:I

Only the openings of the ducts of the following glands car bs demonstrated at this stage of the dissection.

SUBLINGUAL GLAND-3I:8

MAJOR AIND IITINOR DUCTS-31:9, 10

SUBNAXILIARY GLAID-3I:? I

SUBMAXITLLAFY DUJCT-31:12

PAROTID GLAND-31:13--15

PAPOTID DUCF $31: 16$

The following structures are usually difficult to demonstrate in an ordinary dissection:

LIEIAL GLANDS-3I:2

BUCCAL GLANDS- $-31: 3$

MOLAR GLAINDS-31:4 

PALA IINE GLANDS-31:5

LINGJAL GLANDS-31:6

ANTERIOR LINGUAL GLAND-31:7

d. Teeth-31:18

SUPERIOR AND INFTIOR DENIAL ARCHES-31:45, 46

INCISOR TEPTH $-31: 47$

CANI河 TEEIH $-3 I: 48$

PREMOLAR TEFETI-31:49

MOLAR TEETH-31:50

DENS SEROTINUS-31:51

PERMANENT AND DECIDUOUS TEETH-31:52, 53

e. Tongue $-\hat{z}]: 54$

DORSUI OF THE TOIVUUP $-31: 55$

ROOT CF THE TONGTE-3].56

BODY OF THE TONGUE-31:57

INFERIOR SUFEACI $-31: 58,59$

IATERAL NAPGIN-3I:60

APE:X-3I:6I

MUCOUS MEMIRAIF-31: 62

For the muscles and papillae of the tongue see $x: 7$.

f. Faves - 32:10

Istrmus of the fauces-32:11

Velum pala tinum-32:12

Uัula-32:13

Palatine arches--52:I2

GIOSSOPAIATINE ARCHES-32:15

PIARYNGOPALATINE ARCHES-32:16

SALPINGOPAIATINE FOIDXX $-32: 17$

PLLATINE FONSTI-32:18

TONSILLAP. CRYPIS-32:19

TONSILIAR SINUS-32:20

PLICA TRIANGUIAARIS-32:2I

SUPRATONSILLAR TOS $3 A-32: 22$

3. Soft palate and relatod structures

is satisfactory dissection of the soft palate is made with difficulty in the ordinery cadave material; in demonstrating its structures tho soft pelate should be made tense by means of a hook and the mucous membrane remcved from its oral and pharyngeal surfaces and from the surface of the gloscopalatine and pharyngopalatine arches.

a. Nuscles

GLOSSOPALATINE MUSCLi: ${ }^{x x}-32: 27$

PHARYNGOPALATIIP MUS WIFXX $-32: 23$

SALPIIVGOPHARYNGEUS IUISCIDEXX $-32: 58$

UVULAF NUSCLEXX-32:26

LETATON VELI PALATINE MUSCLEXX $-32: 24$

Exposed by removing the wall of the pharynx between the auditory tube superiorly and the upper math of the superior pharyngeal constrictor auscle inferiorly.

TEISOR VEII PAIATINI NUSCLE-32:25 

b. Arteries

ASCEIDING PAIATIIE ARTER $x x_{-47} 7: 14$

PHARYNGEAL RAII OF THE AECNDDTIG PHARYNGAAL ARTERYXX-47:6

DESCEIDING PALATIVE TRO THE INTERUAL MAXILLARY ARTERYXX-47:62

c. Nerves

PHARYNGSAL RAVI OE THE VAGUS WRVEXX-68:28

Component fibres of these rari are derivatives of the

accessory nerve.

NERVE OF THE TEISOR VELI PALATINIXX-67:38

POSTERIOR PALATINE NERVEXX-67:5

NIDDLE PALATING NERVEXX-67:4

4. Auditory tuhe-78:1].

OSSEOUS PART OF THE AUDITORY TUBE-78:13

CARTIILAGINOUS PART OF THE AUTORY TURE-78:I6

CARTILACE OF THE AUDTTORY TUBE-73:17

NEIIAL CARTILAGINOUS LALINA-78:18

LATERAL CARTIIAGINOUS LANINA-78:19

A.INBPAINOUS IAIITIA-78:20

TUNICA MUCOSA-78:21-23

PHARYNGEAL OPENING CE THE AUDITORY TUBE=78:24

5. NasaI cavity

a. Wasal septin- $35: 39$

CARTILAGINOUS SEPTUN=35:40

Exposed by remoring the mucous membrane firoth the septum.

MESBRANOUS SEPTHIA-35:41

The following siructures may be demonstrated by carefully removing the cartilage and trin bony part of the septum (a small piece at a time), but retaining intact the mucous merbrane of the opposite side.

OLFACTORY NERVES- $66: 3$

2EDIAL SUPERIOR POSTIRIOP. NEAL RAMI-66:62

INASORALAIIIN INRVE-66:63

WEDIAT NASAL RAMI OF THE INTERNAL BRANCH OF THE ATIERIOR ETHATOIDAL NERVE-66:31

POSTERIOR IUASAJ, ARTERIES OF THE SEPTUK $-47: 67$

ANTERTOR AND POSTERIOR ETHMOIDAL ANTERIES-40:6, 7

Difficult to demonstrate in ordinary iaterial.

b. Cavity and lateral walls of the nose

NARES-35:37

CHOANAE $-35: 38$

VESTIBULE OF THE NOSE-35:42

VISRISSAE-79:34

LIMEN NASI-35:43

OLFACTORY SULCUS $-35: 44$

SUPERICR UASAL COIVTHA-35:45

NIDDLE NASAL, CONCHF $-35: 47$

IHIERTOR IHASAL CONCHE-35:43

(CONCHA SUPNDIAA) $-35: 45$

MUCOUS IIIIBRANE-35:49

CAVERINOUS PIEXUS OF TIE CONCHA-35:50

AGGER NISI-35:51

SPHENOETHOIDAL RECESS-35:52

MEATUSES OF TrE NOST-35:53 

SUPERIOR MEATUS-35:54

NIDDTE INATUS-35:55

ATRTUH OF THE AIDDLE NEATUS-35:56

INEERIOR MRATUS $=35: 57$

COMNON IEATUS $-35: 56$

NAS OPUARTNGEAL MEATUS-35:59

RESPIRATORY REGION $-35: 60$

OLFACTORY RETIGN-35:61.

OLFACTORY GLANDB̈ $=35: 62$

NASAL GLANDS $\approx 5: 71$

ETHIOIDAL JNFUNDJDUTULI-35:60

Exposed by forring the middle concha upwards,

HIATUS SEMII UNARIS-35:70

BULIA EUIYHICIJALIS-35:50

NASOLARCRIWA-I DIJCT-75:54 Its inferior opening only.

ETHEOIDAL CEIS -35:67 OnIy their openings are exposed.

c. Paranesal sinuses. $35: 63$

WAXILIARY SINLS $-35: 64$

Its cavity is exposed by sawing upwards through the base of the zygomatic process of the raxilia and removing its lateral wall. SPHENOIDAI. STINUS=35:65

FRONTAL SINUS-35:66

d. Nerves and vessels in the lateral wall of the nasal cavity

OLFACTORI NURVS- $66: 3$

LATERAL NASAT, RAHI OF THE INTERNAL BRANCH OF THE ANTERIOR

ETIHOIDAI NEIVE-66:30

Branches frow the sphenopalatine ganglion:

LATERAL SUPTRIOR POSTERIOR NASAL RAMI-66:61

Difficult to demonsirate in an ordinary dissection.

[LATERAI] INBERTOR POSTERIOR NASAL RAMI-67:i

SPHENOPALATINE AR:TRR $-47: 66$

The descending pelatine branch of the internal maxillary artery-47:

62 , and the anterior and posterior ethmoidal arteries-48:6. 7, also

contribute small twigs to the nasal muco-periosteum.

e. Nasal cartilages-35:5

LATERAL NASAI CARDIIAGE-36:9

CARTILAGE OF THE INASAL SEPTUM-36:7 see also $X: 5 a$.

GREATER ALAR CARTILACES-36:10

LATERAI CRUS-36:12

INEIAL CRUS-3I:3.2

LESSER ÁLAR CARTILACES $-36: 13$

\section{Larynx $-36: 10$}

a. Cavity of the 1 arynx-37:11

The laryngeal cartilages constituting the ground plan of the larynx

are listed under subhead $6 \mathrm{~d}$.

APERTURE OF THE LARYNX-37:13

ARYEPIGLOTTIC FOLD-37:20

CUREIFORI TUERRGL-36:74

CORNICULATE TUPERCLE-36:75

INTPPARYTEIOID NOTCH-3\%:35

IUEDIAN GLOSSOEPIGLOITIC FOLD-37:26

LATERAI GLOSSOEPIGLOTIIC FOLD-37:27 

EPIGLOMTIS VALIECULA $-37: 12$

VESTIBULE OF THE IARYNX-37:14

FIMAA VESTIBULI-37:I5

VENTRICULAR FOLDS-37:30

SUPERIOR APERTURE OF THE GLOTTIS-37:34

LARINGEAL VENTRTCIS-37:2I

APPENDIX OF THE IARYNGEAL VENTRICLE-37:22

VOOAE FOLD-37:31

MACULA FLAVA-37:32

The vocal and ventricular folds subdivide the laryngeal cavity into three subdivisions; a superior, or the vestibule, a middle subdivision corresponding to the ventricles, and an inferior subdivision inferior to the level of the vocal cords.

VOCAL IIP-37:16

GLOTIIS-37:17

RIMA GLOTIIDIS-37:10

INTTRIMIABRANOUS PART-37:19

INTERCARTIIAGINOUS PART-37:20

INFERIOR APERTURE OF THE GLOTTIS- 37:33

LARYNGEAL MUCOLS IENBRANE-37:23

LARYINGAL GLANDS-37:36-39

LMPHATIC NODUIES OF THE LARYNX-37:40

b. Laryngeal muscles, hyothreoid and elastic membranes

Having examined the relations of the thryreoid gland, the following structures are exposed by removing this organ together with the omohyoid, sternohyoid, sternothyreoid, thyreohyoid and inferior pharyngeal constrictor muscles, guarding against injury to the internal and external rami of the superior laryngeal nerve, the inferior laryngeal nerve, and the superior and inferior laryngeal arteries.

HYOTHYREOID MEMBRANE-36:34

MIDDLE FYOTHYREOID LIGADENT-36:33

IATERAL HYOTHYRBOID LIGAYENT-36:31

TRITICEOUS CARTILAGE $-36: 32$

CRICOTHYREOID MUSCLE-36:70

STRAIGHT PART-36:79

OBLIQUE PAPT $-37: 1$

POSTERIOR CRICOARYTAFNOID BUSCLE-37:2

Exposed by removing the tunica mucosa from the posterior aspect of the cricoid and arytaenoid cartilages, retaining intact, however, the supericr and laryngeal artery and nerve. OBLIQUE ARYTAENOID MUSCLE-37:9

ARYEPIGLOTTIC MUSCLE-36:77

TRANSVERSE ARYTAZNOID MUSCLE $-37: 10$

It is preferable to demonstrate the folloring muscles and the elastic membrane in only one half of the larynx, reserving the other half for the demonstration of nerves and vessels.

LATERAL CRICOARYTAENOID MUSCLE-37:4

Exposed by renoving the cricothyreoid muscle, raking an incision through the lamina of the thyreoid cartilage parallel to and a little to the right of the anterior median line, dividing the right lateral hyothyreoid ligament, disarticulating the right inferior cornu of the thyroeid cartilage and completing the removal of the lamina.

THYRPOARYTAENOID MUSCLT-37:0

VOCAL IHUSCLE-37:6 

Exposed by carefully removing the lateral cricoarytaenoid muscle. THYREOEPIGIONTIC MUSCLE-37:7

VENTRTCULAR MUSCIE $-37: 5$

Difficult to demonstrate in an ordinary dissection.

ELASTIC NEMBRANE OF THE LARYIX-37:24

Exposed by removing the vocal muscle.

ELASTIC CONE $-37: 25$

VOCAL LIGAMENI-36:63

(SESAMOID CARTIEAGE) $-36: 64$

VENTRICULAR LIGAMENT-36:62

c. Iazyngea i nerves and vessels

The foliowing structures may be demonstrated in the remaining half

of the larynz:

INTERNAL PAIIUS OF NHE SUPERTOR LARYNGEAL NERVE-68:32

Its pesition in the piriform sinus may be determined by produc-

ing a traction on the nerve external to the hyothyreoid membrane

and demonstrating the fold of the laryngeal nerve-37:29

ANASTONOTIC RANUS WITH THE INEERIOR LARYNGFAL NERVE-68:33

INEERIOR I ARYNOSAI NERVE-68:40

ANTPRIOR RAMUS - 68:41

POSTERICR PAMUS $-68: 42$

SUPERIOR LARXNGEAI ARTERY-46:64

INFERIOR LARYNCEAI ARIERY-48:50

d. Jaryogeal cartilages and li gaments

EPICLOTTIS- $36: 6^{1 /}$

PETIOLUS EPIGLOTTIDIS-36:68

EPIGLOTNIC TUBERCLE-36:69

EPIUIOTIIC CARTIIAGE-36:70

THYREOEPIGTOTTIC LIGAMENT-36:71

HYOEPIGLOTTIC IIGAAENT-36:72

THYREOID CARTIJAACE $-36: 21$

RIGHT AND IEFI LAMINA-36:22

PROMINEEIIIA IARYNGEA-36:16

SUPERIOR THYREOID INCISURE-36:23

INFERIOR THYREOID INCISURE-36:24

SUPERIOR THYREOID TUBERCLE-36:25

INHERTOR THYREOID TUBERCLE-36:26

IOBEIQUE LINE) -36:27

SUPEPIOR CORNUT-36:28

INFERIOR CORNU-36:29

(THYREDID FORAIEN) $-36: 30$

CRICOTHYRE:ID ARTICULATION-36:40

ARTICULAR CAPSUIE-36:41

CERATOCRICOID LAGAMENTS XX-36:42-44

CRICOID CARTILAGE-36:35

The exposure of the cricoid cartilage is completed by dividing

the ligaments connecting the thyreoid and cricoid cartilages

and removing the thyroeid cartilage.

ARCH-35:36

LAMINA-36:37

ARYTAENOID ARTICULAP SURFACE-36:38

THYREOID ARTICUAR SURFACE-36:39

CRICOTRACHEAL LIGANENI-36:46

CORNICULATE CARTILACE-36:57

ARYCORNICULATE SYINCHONDROSIS-36:58 



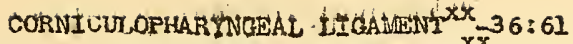

$$
\text { CRICOPHARYNGEAT IIGAMENT }{ }^{\times x}-36: 60
$$

ARYTAENOID CARTILAGE-36:47

APEX-36:54

BASE $-36: 49$

ARIICULAR SURFACE-36:48

CRISTA ARCUATA ${ }^{x x}-36: 50$

COLLICULUS ${ }^{X X}-36: 51$

FOVEA OBLONGA $x x-36: 52$

FOVEA TRIANGULARIS ${ }^{\mathrm{XX}}-36: 53$

VOCAL PROCESS-36:55

MUSCULAR PROCESS-36:56

CUNEIFORM CARTILAGE-36:73

CRICOARYTAENOID ARTICULATION-36:59

ARTICULAR CAPSUE-36:65

POSTERIOR CRICOARYTAENOID LIGAMANT ${ }^{2 X X}-36: 66$

7. Tongue $-31: 54$

a. General eharacteristics and surface anatomy

DORUM OF TONGUE-31:55

ROOT OF TONGUE-31:56

BODY OF TONGUE-31:57

INFERIOR SURFACE-31:58

FIMBRIATED FOLD-31:59

LATERAL MARGIN-31:60

APEX OF TONGUE $-31: 61$

MUCOUS IIEMBRANE OR TONGUE-31:62

FRENULUN OF TONGUE-31:63

LINGUAL PAPILLAE-31:64

FILIFORM PAPILLAE-31:65

CONICAL PAPILIAE-31:66

FUNGIFORM PAPILLAE-31:67

LENTICULAR PAPILLAE-31:68

VALLATE PAPILLAE, $31: 69$

FOLIATE PAPILLAE-31:70

MAEDIAL SULCUS-31:71

TERMINAL SULCUS-31:72

FORAIEN CAECUM-31:73

(LINGUAL DUCT) $-31: 74$

THYREOGLOSSAL DUCT-31:75

LINGUAL TONSIL-31:76

LINGUAL FOLLICLES $-31: 77$

b. Muscles of the tongue-32:1

Preferably demonstrated in one half of the tongue only retaining the other half for the demonstration of nerves and vessels.

GENIOCLOSSUS MUSCLE-32:2

HYOGLOSSUS MUSCLE $-32: 3$

CHONDROGLOSSUS MUSCLE-32:4

STYLOGLOSSUS MUSCLE-32:5

The four preceding muscles may be characterized as extrinsic and

the following three muscles as intrinsic muscles of the tongue:

LONGITUDINALIS SUPERIOR MUSCLEXX-32:6

LONGITUDINALIS INFERIOR MUSCLEXX-32:7

TRANSVERSES LINGUAE MUSCLEXX-32:8

VARTICALIS LINGUAE MUSCLEXX $-32: 9$ 

SEPTUR OF TCNGLT-31:78

c. Nerves and vessels of the tongue

LINGUAL RAIII OF THE GLOSSOPHARYNGEAL INRVE-58:21

LINGUAL NRPVE-67:23

SUSLINGLAL IERUE-57:26

LINGUAL, RAMI-67:27

HYPOGLOSSAL NERVE-68:60

LINGUAL RAMI-68:64

LINGUAL ARTERY-47:8

DORSAL RMNI OF TONGUE-47:11

DEEP ARTERY OF TONGUE-47:12

8. Structures in the middle cranial fossa

Incisions for removal of the dura mater; a) having secured the cut ends of the oculomotor, trochlear and trigeminal nerves as they pierce the dura an incision is made through the dura just lateral to these nerves from the anterior clinoid process to the apex of the petrous portion of the temporal bone (the cut should be made no deeper than the thickness of the dura), and then extended from the apex of the petrous bone backward and laterally along the superior petrosal sinus to the signoid sulcus; b) a second incision is mado through the dura from the clinoid process anterolaterally along the posterior rargin of the small wing of the sphenoid bone; d) the dura may then be reflected lateralward, carefully disengaging it from any underlying nerves or other structures trich may be attached to it. CAVERIOUS SIMUS- $53: 24$

SUPERIOR OPHTHALIIIC VEIN-53:54

INFERIOK OPTHALMIC VEIN- 53:68

SPHENOPARIETAL SINUS-53:28

IRIGEIINAL NERVE-66:11

PORTIOINA JOR-66:12 Sensory root.

PORITO IIINOR-66:14 MOtOR root.

SEIILUNAR GANGLION-56:13

MANDIBULAR NERVE $-67: 6$ Origin and foramen of exit only. An accessory meningeal artery $-(47 ; 51)$ is sometimes associated with it in its foramen of exit. MAXILEARY NEPVE-66:38 Origin and foramen of exit. MENIVICEAL RADUUS-66:39

OPHTHALWAIIC NRRVE-66:I5

IACRINAL INPVE-66:17 Its origin only.

IASOGILIARY NERVE-65:23 Its origin only.

FRONTAL NERE-66:19 Its origin only.

The following three nerves are listed with reference to the cavernous sinus only:

OCULOROTOR NRRVE- $66: 5$

TROCHEFAR IERVE-66:9

ABDUCENT NRPVE:-67:46

CAVERNOUS PLEXUS OF THE SMPATHEIC-71:39 Difîcult to demonstrate. INTERNAL CAROTID ARTERY $47: 68$

OPHTHALNIC ARTSKY $-47: 70$ I士s origin only.

INTERNAL CAROTID PLEXUS OF THE SMPATHETIC-71:38 Difficult to

demonstrate in an ordinary dissection.

GREATER SUPERFICIAL PETROSAL IERVE-66:59

LESSER SUPERFICIAL PETROSAL NERVE-67:37

MIDDEF UENINGSAL ARTERY $47: 50$ 



\section{SUPERFICIAL PETROSAL RAIRS ${ }^{X X}-47: 52$ \\ (ACCESSORY I WNINGEAL FAIRS ) -47:51}

9. Eyelids and lacrimal apparatus

For the surface anatomy of the eye see section $V: 1$.

a. Eye1icis-75:11

In demonstrating the following structures the palpebral part of the orbicularis oculi muscle is retroved, guarding against injury to underlying nerves and vessels.

ORBITAL SEPTUS-75:5

SUPEREOR TARSUS-75:2:

INFERTOR TARSUS-75:24

TARSAI GLANDS-75:27

LATERAL PALPEBRAL RAPHE-75:26

AEDIAI. PALPEERAI LIGAIENT-75:25

LEVATOR PALPEBRA SUPERTORIS AUSCLE-75:3 Its tendon of insertion only.

For nerves and vessels of the eyelids see $I: 2 a$ and $V: 4$.

b. Lacrimal apoaratus $-75: 41$

SUPERIOR IACRIMIA GLAMD-75:42

Should be identified mith a minimum dissection.

Exposed by dividing the palpebral fascia at the upper and lateral angle of the orbit.

INEERIOR IACRTIAL GLAND-75:43

(ACCESSORY IACRIMAI GIAND) $-75: 44$

EXCRETORY DUCFULES $-75: 45$

LASRIIAL DUCT-75:49

Frposed by reflecting the Eedial palpebral ligament. AMPULLA OF TIE LACRIARI DUCT-75:51

LACRIMPL SAC-75:52

FORNIX OF THE LACEIMAI SAG-75:53

NASOLACRIIAL DUCT-75:54

The following muscles are exposed by dividing the eyelids through the middle by a sagittal section and removing the conjunctiva at the medial angle of the eye.

TAPSALIS SUPERIOR IFUSCL F $^{\times x}-75: 29$

TARSALIS INFERIOR MUSCLEXX $-75: 30$

10. Structures in relation to the orbit

a. Structures in the superior part of the orbit and fascia of the eyeball

Exposed by removing (with a bone forceps, sam and chisel) the thin roof superior wall of the orbit (12:67), the thick cranial wall above the orbital opening (12:64), and the superior wall of the superior orbital fissure (12:71), retaining intact, hovever, the superorbital wargin (12:65) of therbital opening and a ring of bone around the eptic foramen (cutting avay the anterior clinoid process will also facilitate the subsequent dissection), dividing the periostevi longitudinally midway between the medial and lateral walls of the orbit and also transversely close to the anterior margin of the superior orbital wall, and reflecting the two periosteal flaps laterally and medially. 

FRONTAL NERVE-65:19

SUPRAORBITAI. NERVE-66:20

FRONTAL RAMLS-66:2.1

SUPRATROCHLAAR NERVE-66:22

Attention has already been directed to the peripheral

distribution of these nerves, I:2a and V:4.

CORPUS ADIFOSUM ORBITAE-75:9

To be removed gradually during the ensuing dissection.

TROCHIEAR NERVE-66:9

LACRIMAL NERVE-66:17

LACRINAL GLANDS-76:42-45 See also $9 \mathrm{~b}$.

IEVATOR PALPEBRAE SUPERIORIS MUSCLE-75:3

FASCIA OF EYEBALL-75:7

Exposed by dividing the frontal nerve and levator palpobrae superioris muscle in the middle of the orbit and reflecting their cut ends.

INTERFASCIAL SPACE-75:8

Its extent may be determined by aking an opening through

fascie and introducing the the nandle of a scalpel or a

blunt forceps into the spening.

RECTUS SUPERIOR MUSCLE-74:65

OBLIQUUS SUPERIOR IIUSCLE-74:71

TROCHISA $=75: 1$

b. Optic nerve, nasociliary nerve and ciliary ganglion

The following structures are exposed by dividing superior rectus muscle midway between its origin and insertion, reflecting the cut ends (noting the superior division of the oculomotor nerve subjacent to its posterior part), and carefully removing the orbital fat. OPTIC NERVE-66:4

NASOCILIARY NERVE-66:23

LONG ROOT OF THE SILIARY GANGLION-65:24

LONG CILIARY NERVES-66:25

POSTERIOR ETHAOIDAL NERVE-66:26

ANTERIOR ETHNOIDAL NERVE-66:27

INFRATROCHLEAR NERVE-65:33-35

CILIARY GANGLION-56:63

SHORT CILIARY NERVES-66:37

c. Blood vessels of the orbit

OPHTHALMIC ARTERY $=47: 71$

CENTRAL ARTERY OF RUTINA-47:72

LACRIMAL ARTERY $-47: 72$

MUSCULAR RAMI-47:74

CILIARY ARTERIES-47:75, 76, 48:1-4

SUPRAORBTTAL ARTERY $-48: 5$

ANTERIOR AND POSTERIOR ETHWOIDAL ARTERIES-48:6, 7

MEDIAL PALPEBRAL ARTERIES-48:9-11

FRONTAL ARTERY-48:12

DORSAL ARTERY OF NOSE-48:13

SUPERIOR OPHTHALMTC VEIN-53:54

INFERIOR OPHTHALIIC VEIN $-53: 68$

CENTRAL VEIN OF RETINA-53:6

Tributaries of the ophthalmic veins art indicated in $53: 55,53: 64-67$

d. Remaining structures of the orbit

RECTUS MEDIALIS MUSCLE-74:67 

RECTUS INFERTOR IUUSCIE-74:66

RECTUS LAIERATIS RUSCLE-74:68

LACERTUS OF RECIUS LATERALIS MUSCIE-74:69

COLEAN TENDINOUS RIVIG OF ZINN-74:70

Exposed by dividing the optic nerve close to the optic foramen and turning the eyeball anteriorly.

OCULOISOTOR NERVE-66:5

SUPERIOR RAMUS-66:6

INFERIOR RAMUS-66:7

SHORT ROOT OF CILIARY GAINGLION $-66: 8$

ABDUCENS NERVE-67:46

OBLIQUUS INFERIOR RUSCLE-75:2

Exposed by replacing the eyeball in its normal position,

everting the lower eyelid, carefully removing the conjunctiva

in the region of the inferior fornix.

ZYGOHATIC NERVE-66:40

11. Structures in the carotid and infraorbital canals, and in the pterrgopalatine fossa.

a. Carotid cana $1-9: 41$

The cuntents of the carotid canal may be exposed by removing (with

a bone forcepe) the inferior wall of the carotid canal, guarding

against injury to the auditory tube.

INTERNAL CAROTID ARTERY-47:6.3

GAROTICOTYRPANIC RAIUUSX $-47: 69$

INTERNAL CAROTID IERVE OF SYMPATHETIC SYSTEM-71:37

INTERNAL CAROTID PLEXUS-71:38

JEEP PETROSAI NERVE-66:60

Its origin only

b. Naxillary nerve and infraorbital caral

The structures in relation to the infraorbital canal and pterygopalatine fossa may be exposed by raking the following dissections: a) begin at the cut margin of the skull just above the external acoustic meatus and seving through the squamous part of the temporal bone and great wing of the sphenoid bone in a plane passing obliquely downward and forward to the medial end of the superior orbital fissure, the saw-cut passing just lateral to the foramen rotundum; b) making a second saw-cut extending from the cut margin of the cranial wall, just above the anterior margin of the great $*$ in sifohenoid, downward into the superior orbital fissure, joining the first saw-cut; c) detaching the vedge of bone included between the two saw-cuts and with a bone forceps removing what remains of the great wing of the ophenoid bone lateral to the foramen rotundum, retaining intact, however, the bony circumference of this aperture; d) and finally with a bone forceps (and chisel if necessary) removing the superior of the infraorbital canal.

MAXILIARY IMRVE-66:38

ZYGOIATIC NERVE-66:40

SPHENOPALATINE NERVES-66:43

POSTERIOR SUPERIOR ALVEOLAR RAMI-66:45

INFRAORBITAL NERVE-66:46

MIDDLE SUPERIOR ALVEOLAR RAMUS-66:47

ANIFR.IOR SUPERIOR ALVEOLAR RAMI-66:48

SUPERIOR DENTAL PIEXUS-66:49

This plexus also includes the posterior superior alveolar rami. 



\section{SUPERIOR DEITAL RAII- $56: 50$ \\ SUPERIOR CINGIVAL RAMI-66:51 \\ INERAORBITAL ARTEYY $=4 \%: 60$ \\ ANTERIOR SUPERIOR ALVEOLAR ARTYRIES $-47: 61$}

\section{c. Sphenopalatine ganglion}

The splenopalaine ganglion ray be located by following the latera? superior rasal rami together with the nasopalatine nerve back to the sphenopalatine foramen, and the lateral posterior inzerior rami of the anterior palatine nerve back to the pterygopaiating canal, carefully opening the canal and following the palatine nerses riprasd to the sphenopalatine ganglion which is situated in the fterygopa.latine fossa; the exposure of the gangiion may also be facilitited by removing the orbital process of the palatine bone and a portion of the kody of the ringenoid bone.

SPHENOPALATIN GANGLTON- $66: 56$

IERVE OF THE PTERYGOID CANAL-66:58

This nerve may be exposed by cutting away the sphenoidal process of the palate bone and carefully opening the pterygoid process oi the sphenoid bone, a dissection difficult, however, to rake.

GREA TRR SUPTRF -CIAI PETROSAL NERVE-66:59

DEEP PETROSAL NERVE-66:60

ORBTTAL RAMT $=66: 57$

LATERAL SUPETIOR POSTERIOR NASAL RAMI-66:61

MEDIAL SUPERI OR POSTPRTOR NASAI RANI-66:62

NASOPATATTIE IERVE- $66: 63$

[LATERAL] TIVTRIOR POSTIRIOR NASAL RANI-67:1

PALATINE NEIITS-67:2

ANTERTOR. PALATINE NERVE $-67: 3$

INIDDI

POSTERIOR PALATINE NERVE-67:5

\section{d. Internal maxillary artery}

The folowing terminal branches of the internal maxillary artery are in relation to the pterygopalatine fossa with reference to their origin only.

POSTERIOR SUPERTOR ALVEOTAR ARTERY-47:59

INFRAORBITAL ARITRY-47:60

DESCENDING PAIATINE ARTERY $-47: 62$

SPHDNOPALATINE ARTERY $-47: 66$

12. Auditory apparatus: external and middle ear

It will be observed that the incisions made through the skull in the course of the preceding dissections have restulted in the isolation of a somewhat wedge-shaped segment of the cranium including the greater part of the temporal bone and the organ of hearing. With reference to the three subdivisions of the organ of hearing, some of the structures relative to the external ear have already been listed under Section $I: 4$, and attention directed to the auditory tube of the middle ear.under section $x: 4$.

\section{c. c. Walls of the tympanic cavity}

The tympanic cavity and its several walls may oe demonstrated by removing the squamous part of the temporal bone by a horizontal sawcut made just above the level of the petrous part of the temporal bone and waking an opening through the tegmen tympani of the temporal bone (9:12) just lateral to the arcuate eminence $(9: 13)$, and about 

$1 \mathrm{~cm}$. anterior to the superior angle $(9: 8)$ of the pyramids of pars petrosa (9:3), and exposing the tympanic antrum of the mastoid wall of the tympanic antrum of the mastoid wall of the tympanic cavity

$(77: 17)$; this opening may then be carefully enlarged with a bone forceps and the entire roof or tegmental wall of the tympanic cavity removed.

TEGIIENTAL WALL-76:69

EPITYPANIC RECESS-77:1

PARS CUPULARIS $-77: 2$

JUGULAR WALL-77:3

STYLOID PRORIINENCE-77:4

MASTOID WAIL-77:16

TYMPANIC ANTRUM- $77: 17$

PROMTNENCE OF LATERAI SEMICIRCULAR CANAL-77:18

PROMIPENCE OF FACIAL CANAL-77:19

PYRALITDAL EMINENCE-77:20

FOSSA OF INCUS $-77: 21$

POSTERIOR SINUS-77:22

TYMPANIC APERTUPE OF CANALICULUS OF THE CHORDA-77:23 CAROTID WALL- 77:26

LABYRINTHIC WALL-77:5

FENESTRA VESTIBULI $=77: 6,7$

PROMONTORY $-77: 8-10$

SINUS OF TYMPAWUM-77:11

FENESTRA CECHIAP-77:12-14

PROCESSUS COCHLFARIF̈ORMIS-77:15

IEASTOID CELLS-77:24

TYMPANIC CEILS $-77: 25$

MEUBRANOUS FALI $-77: 27$

TIMPANIC IMEABRANE-77:28

PARS FLACCIDA-77:29

PARS TENSA-77:30

LIMBUS MEUBRANAE TIAPANI-77:31

ANIERIOR MALLPOLAR FOLD-77:32

POSTIRIOR MALIEOLAR FOLD-77:33

MALLEOLAR PROUIIIENCE-77:34

MALLTOLAR STRIA-77:35

URBBO MEIMBRANE TYMPANI-77:36

FIBROCARTILAGINOUS RING-77:38

Structurally the tympanic membrane consists of several tissue layers $-77: 37,77: 41$

MUCOUS MEABRANE OF THE TYNPANIC CAVITY-78:1

b. Auditory ossicles, articulations, ligaments and muscles STAPES $-77: 43$

HEAD $-77: 44$

ANTERIOR LIHIB-77:45

POSTERIOR LIMB $-77: 46$

BASE $-77: 47$

INCUS $-77: 48$

BODY $-77: 49$

LONG IIMB $-77: 50$

LENTICULAR PROCESS-77:51

SHORT LTMB-77:52

MALIEUS-77:53

RIANUBRI UR-77:54

HEAD-77:55 

NECK $-77: 56$

LATERAL PROCESS $-7 \%: 57$

ANTERIOR PROCESS-77:58

ARTICULATIONS OF THE AUDITORY OSSICLES-77:59

ARTICULATION BETWEEN INCUS AND MALLEUS-77:60

ARTICULATION BETWEEN INCUS AND STAPES-77:61

SYNDESNOSIS OF STAPES AND TMMPANUV -77:62

LIGALANTS OF THE AUDITORY OSSICLES-77:63

The following ligaments are difficult to expose in an ordinary

dissection:

ANTERTOR IICAMENT OF MALIEUS-77:64

SUPERIOR LIGAIENT OF MALLEUS-77:65

LATERAL LIGANENT OF MALLEUS $-77: 66$

SUPERIOR LIGAMENT OF INCUS-77:67

POSTERIOR LIGALENT OF INCUS $-77: 68$

OBTURATOR IIENBRANE OF STAPES-77:69

ANNULAR LIGANENT OF BASE OF STAPES-77:70

MUSCLES. OF AUDITORY OSSICLES-77:72

TENSOR TYMPANI MUSCLE-77:73

STAPEDIUS INUSCLE $-77: 74$

ALDITORY TUBE-78:11 See also Section $X: 4$.

c. External acoustic meatus-78:25.

Its interior is exposed by removing (with a bone forceps and chisel). the anterior wall of the external acoustic meatus, guarding against injury to the tympanic membrane.

EXTERNAI ACOUSTIC PORUS-78:26

TYMPITNIC INCISURE-78:27

CARTILACINOUS EXTERNAL ACOUSTIS REATUS-78:28

CARTILAGE OF ACOUSTIC MEATUS-78:29-31

The auricle of the external ear has been dealt with under section $I: 4$.

13. Intrasseous course of the $f$ cial, intermediate and acoustic nerves

The squamous portion of the temporal bone has already been removed,

$X: 12 a$, and the upper part of the petrous part of the bone may now

be removed by a horizontal saw-cut just above the roof of the internal acoustic meatus, the cut extending laterally into the tympanura In relation to the rastoid wall of the tympanum attention has already been directed to the prominence of the facial canal in which runs the facial nerve, $X: 12 a$. This canal may now be opened with a bone forceps and chisel, followed into the labyrinthic wall of the tympanum, the roof of the internal acoustic meatus removed and the facial nerve exposed through the superior part of the facial canal. The inferior part of the facial canal may be demonstrated by removing the bone posterior and lateral to it by means of the two following saw-cuts: a) a frontal (vertical transverse) cut in a plane just posterior to the stylomastoid foramen; b) a sagittal (vertical anteroposterior) cut just lateral to the stylomastoid foramen to meet the first cut, removing the excieed bone with a bone iorceps and chisel.

FASIAL NERVE-67:47

GENU OF THE FACIAI NERVE- $7: 48$

GENICUEATE GANGLION-67:49

STAPEDIUS NERVE-67:50

ANASTOMOSING RAHUS WITH THE TIMPANIC PLEXUS-67:51

INTERMEDIATE NERVE-67:63 

GREATER SUPARFICIAL PETROSAL NERVE-66:59

This nerve, while transwitting sensory fibers of the intermediate nerve, is classed systematically with the aphenopalatine ganglion and not as a branch of the intermediate nerve. CHORDA TIPPANI $-67: 64$

ACOUSTIC NERVE-67:65

XI. Brain: General Characteristics, Meninges, Blood Vessels and Cerebral Nerves

1. Larger subdivisions of the brain

For the removal of the brain see II:2a. A demonstration of its structures can best be undertaken in a specimen which has been hardered in formalin. The following subdivisions of the brain $\mathrm{n}$ ? $\mathrm{y}$ be identified by inspection without disturbing the meninges and blood vessels. ENCEPHALON OR BRAIN-59:10 RHOMBENCEPHALON $-59: 11$ MYEIENCEPHALON-59:12 MEDULLA OBLONGATA $-59: 13$ INETENCPPHALON-60:18 PONS $-60: 19$ CRREBELLUM-60:53

CEREBRUM- $61: 36$ IUESENCEPHALON-61:40 PROSENCEPHALON $-62: 12$ DIENCEPHAION-62:13

Cannot be favorably demonstrated in the intact brain. TELENCEPHALON-63:5

Subdivided into hemispheres $-63: 6$ separated by the longitudinal fissure of the cerebrum-63:8.

2. Meninges, and blood vessels of the brain

Some of the following structures have already been listed in connection with the removal of the brain $I I: I$.

a. Meninges $-65: 32$

DURA MATER OF BRAIN-65:33

FALX CEREBRI-65:34

TENTORIUM CEREBELLI $-65: 35$

FALX CEREBELLI-65:36

DIAPHRAGMA SELLAE- $65: 37$

FORAIIEN DIAPHRACMATIS $-65: 38$

INCISURA TENTORII-65:39

ARACHNOID OF BRAIN-65:45

SUBARACHNOID CAVITY $-65: 46$

SUBARACHNOID CISTERNS-65:17

The structural characteristics of the subarachnoid cisterns may be demonstrated by ming a median sagittal incision through the arachnoid membrane it the region of the anterior surface of the redulla oblongate and pons and 

carefully reflecting the two flaps of the arachnoid lateraliy.

CISTRRIN CEREBELLONEDULLARY ${ }^{\mathrm{XY}}-65: 48$

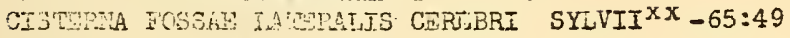

CT3TLPNA CH:

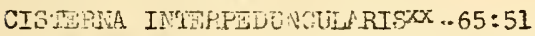

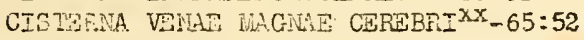

ARACHNC IJI GRARUATTONS-65:53 Seo also II:l.

PIA MATER OF TEE BRAIN-65:54

b. BJ.ood vesss].s of the brain

Demonstrated by carefuliy removing the arachnoid membrane with scissors and fcrceps so far as this can be done without injuring or lacerating the brain itself.

VERTHBRAT AR:EKY-48:21

POS FPEOR SPINAL ARTERY $20 x_{-48: 23}$

ANTY:-OR SPINAL ARTERYYX $-48: 24$

POSTERIOR IITERIOR CEREBEIIAR ARTERY-48:26

BASILAR ARTIRY $-43: 27$

ANTERIOR INESTOR CEREBELLAR ARTERY-48:28

INTERIJAL AUDTIORY ADIERY

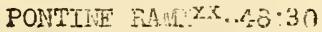

SUPEETOR CLREBELTAR ARTERY-48:31

POSTENIOR CEREBRAI APTERV-43:32

AREERIAI CIRCTE OF VILIIS $-48: 33$

INTERNAL CAROTID ARTERX-47:68

POSTERIOR CONCUNICAITNG ARTERY-48:15

CHORIOTD A- IERYXX - $13: 16$

AINTERIOE CESTBPAL ARTTRY-48:17

AYMERTOR COHAUVA TNG ARTERY-48:18

MIDDLE CAFBBRAL ARTERY-48:19

VEINS OF THE ERAIN-53:41

For the 3inuses of the dura mater see II;2c. The cerebral veins are tributaries of these sinuses. The deeper veins cannot be favorably demonstrated at tise present stage of the dissection; the Iol?cwing veins are superficial in position:

SUPERIOR CEREBRAL VENS-53:42

MIDDIT CEREBRAL VEIN-53:43

INFEIIOR CERERRAT, VETNS- $53: 44$

SUEFLIOR CEREBELLAR VEINS- $53: 45$

IIVEYIOR CEPIBEILAR VEINS-53:46

BASAL VETN-53:51

3. Base of the brain and the cerebral nefves

a. Base of the brain

Exposed by renoving (with a forceps and scissors) the remaining parts of meninges and blood vessels from the base of the brain, care being taken to guard against the tearing away of the cerebral nerves. CEREBRAI PEDTNSLE:S-61:46

OPTIC CHIASW: $02: 36$

OPTIC TRACF- $-62: 33$

INTERPENDLNCUIAA FOSSA-61:42

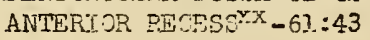

POSTEFIOR FECESSXX-61:44

POSTERIOR PERFORATED SUBSTANCE- $61: 45$

MAMILLARY BODIES-62:26 

TUBER CINEREUM- $62: 28$

INFUNDIBULUN- $62: 29$

LONGITUNINAL FISSURE OF CEREBRUA-63:8

LATEPAL FISSURE OF CEREBRUR-63:16

PONS-60:19

MEDULIA OBLONGATA-59:13

b. Cerebral nerves

OLFACTORY NERVES- 66:3

OPTIC NERVE-66:4

OCULOMOTOR NERVE-66:5

TROCHEEAR NERVE-66:9

TRIGEINAL NERVE-66;11

PORTIO NAJOR-66:12

PORTIO ININOR- 66:14

ABDUCENS NERVE-67:46

FACIAL NERVI-67:47

INTERMEDIATE NERVE-67:63

ACOUSTIC NERVE-67:65

VESTIBUIAR ROOT-67:66

COCHLEAR ROOT-67:67

GZOSSOPHARYIVGEAL NERVE-68:8

VAGUS NARVE-68:22

ACCESSORY NEPV Vis-68:57

HYPOGLOSSAL NERVE-68:60

XII. Brain: Surface Anatomy of the Rhombencephalon and Miesencephalon

1. Rhombencephal on-59:11

To facilitate the exposure of structures in the rhombencephalon and mesencephal on the following incisions may be made for the removal of the right hemisphere of the cerebrum and the right half of the cerebellum: a) with a sharp, thin knife making a transverse incision through the right cerebral peduncle just behind the right corpus mamillare, pressing apart the two cerebral hemispheres, exposing the corpus callosum and beginning at the corpus callosum, making a nearly median sagittal incision through all the structures in the middle Iine of the picsencephalon; the latter incision should preferably pass slightly to the left of the midline, leave the septum pellucidum attached to the right hemisphere, and then carried posteriorly until it meets the transverse incision just made through the cerebral peduncle and thus detaching the right cerebral hemisphere; $b$ ) in the same manner a second median sagittal incision is made through the vermis of the cerebellum, guarding against cutting into the floor of the fourth ventricle but carrying the incision forvard through the anterior medullary velum as far as the inferior colliculi of the mesencephalon; finally by cutting through the brachium conjunctivum, brachium pontis and the corpus restiforme on the right, the right half of the cerebellum is detached, (both the right cerebral hemisphere and the right half of the cerebellum being transferred to preserving fluid for later reference.) 

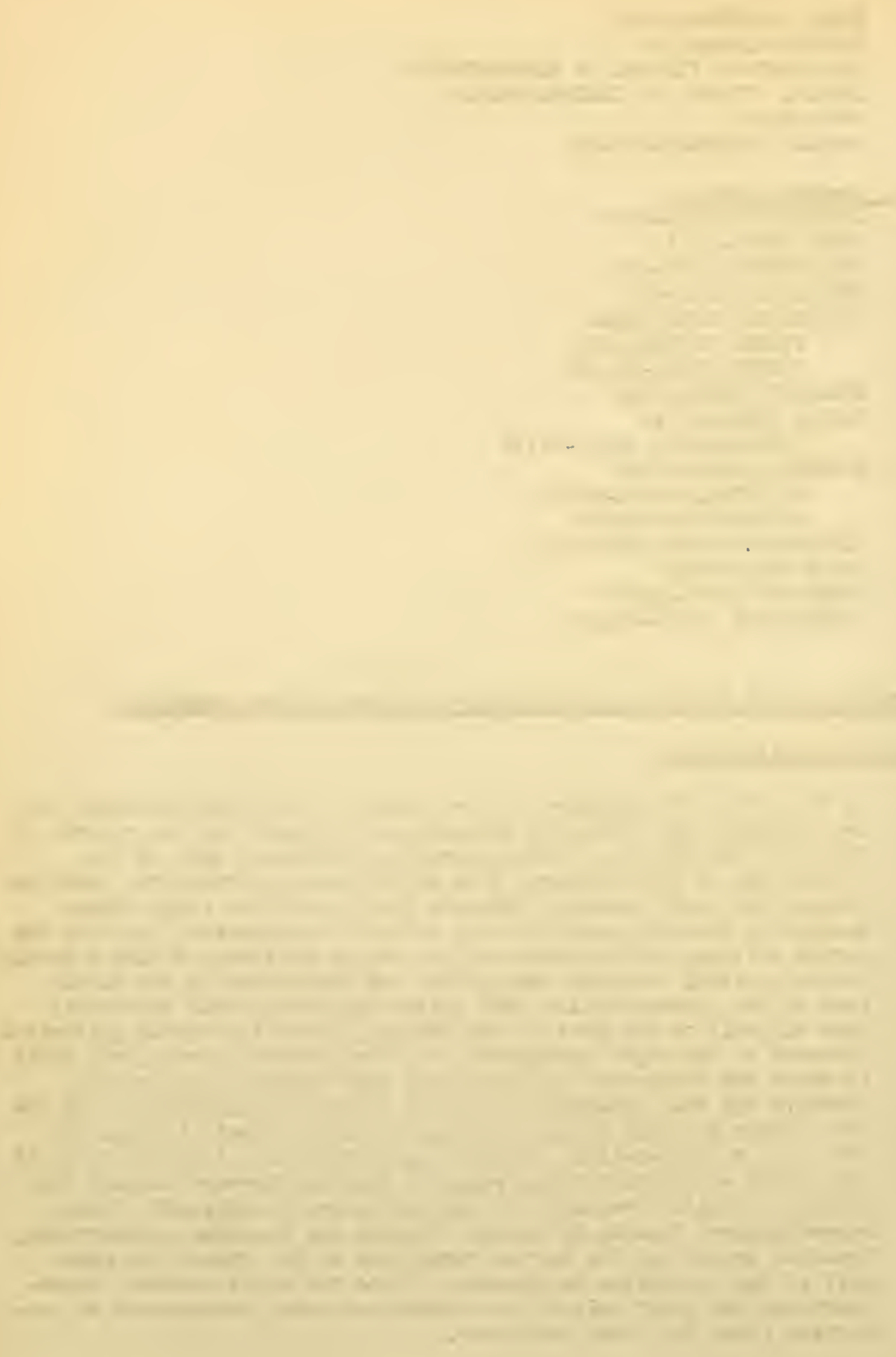
a. Medulla oblongata-59:13

POSTERIOR MEDIAN FISSURE-59:14

ANTERIOR MEDIAN FISSURE-59:15

FORAMEN CAECUI:-59:16

PYRAIID-59:17

DECUSSATION OF PYRABIDS-59: 18

ANTERIOR LATSRAL SULCUS=59:19

POSTERIOR IATERAL SULCUS-59:20

OLIVE-59:21

RESTIFORM BODY $-59: 22$

FUNICULUS LATERALIS-59:23

FUNICULUS CUNEATUS-59:24

TUBERCULUN CINEREULI-59:25

FUNICULUS GRACIIIS-59:26

CLAVA-59:27

EXTERNAL ARCUATE FIBERS-59:28

b. Pons-60:19

BASILAR SULCUS-60:20

BRACHITA PONTIS $-60: 23$

c. Is thmus of rhombencephalon-61:25

BRACHIUM CONJUNCTIVUÁ-61:26

LEINISCUS $-61: 27$

TRIGONUM LEMNISCI- $61: 30$

ANIERIOR IEDULLARY VELUL-61:31

FRENULUI OF ANTERIOR MEDULIARY VELUM-61:32

d. Cerebellum

GYRI OF THE CEREBELLUM-60:54:

SULCI OF THE CEREBELLUM-60:55

VALLECULA CEREBELLI-60:56

INCISURA CEREBELII ANTERIOR-60:57

INCISURA CEREBELLI POSTERTOR-60:58

HORIZONTAL SULCUS-60:59

TRANSVERSE FISS URE ${ }^{\mathrm{XX}}-60: 60$

VERIIS -60:61

LINGULA CEREBELLI-60:62, 63

CENTRAL LOBE-60:04

MONTICUIUS- $50: 65$

CULIMN-60:66

DECLIVE-60:67

FOLIUM VEPUIS-60:68

TUBER VERHIS-60:69

UVULA- 60:71

NODULE-60:72

HEMISPHERE OF CEREBELLUM-60:73

SUPERIOR SURFACE $-60: 14$

ALA .LOBULI CENTRALIS-60:75

LOBULUS QUADRANGULARIS $-60: 7 \%$

PARS ANTERIOR-60:77

PARS POSTERIOR- $-0: 78$

LOBULUS SHIIULNARIS SUPERIOR-6I:1

INFERTOR SURFACE-61:2

LOEULUS SEMILUNARIS INFERIOR-61:3

LOBULUS BIVENTER-61:4

TONSIL OF CEREBULLU M-61:5

FLOCCULUS $-61: 6$ 

2. Fourth ventricle-59:58

a. Floor of the fourth ventricle RHOIPOID FOSSA-59:59

PARS INFERIOR [CALAWUS SCRIPTORIUS] -59:60

PARS INTERIEDIA-59:62

LATERAL RECESS $-59: 63$

PARS SUPERTOR-59:64

SULCUS LIMITANS-59:65

FOVEA INFERIOR-59:66

FOVEA SUPERIOR-60:1

TTGONLN N. HYPOCLOSSI-60:2

STRIAE MEDULIARES-60:3

ERIINENTIA NEDIALIS-60:4

1.JLIICULUS FACIALIS-60:5

ALA CIITERTA $-60: 6$

AREA \& CÜSTICA-60:7

LOCUS CAERULEUS-60:8

b. Roof of the fourth ventricle-60:9

POSTERIOR HEDULILARY VEIUN $=60: 10$

TAENIA VENTRICULI QUARII-60:11 OBEX-60::22

EPITHEIIAL CHORIOID LAYER-60:13

MEDIAN APERTURE [FORAIEN OF MAGEHDIE]-60:16

LATERAL APERTURE-60:16

FASTIGIUN-60:17

3. Mesencephalon-63:40

For structures relative to the inferior surface of the mesencephalon$61: 41-45$, see $X J: 3 a$.

CEREBRAL PEDUNCIES-61:46

AQUAEDUCTIS GEREERI- $61: 47$

SULCLS LATERALIS-61:48

SULCUS N. OCULOHOTORII-61:49

QUADRIGENINAL BODIES-62:I

LAIUINA QUADRICEIINA-62:2

COLLICULUS SUPERIOR-62:3

COLIICULUS INFERIOR- $62: 4$

BRACHIU: QUADRIGEMINUA SUPERIUS-62:5

BRACHIUNI QUADRIGEMTNUR INFERIUS- $62: 6$

XIII. Brain: Surface Anatomy of the Prosencephalon

11 General vuictivisions of the prosencephalon

The remaining cerebral hemisphere may be detached by carefully cutting through the left cerebral peduncle just posterior to the left mamillary body, the rhombencephal on and mesencephal on being transferred to preserving fluid for : later reference.

PROSENCEPHALON- $62: 12$

DIENCEPHALON $-62: 13$

THA: IAIIENCEPHALON-62:51

PARS MAIMILLARIS HYPOTHALAMI- $62: 25$

TELENCEPHALON-63:5 

HEMTSPHERE- $63: 6$

RARS OPTICA HYPOTHALAMI-62:27

2. Telencephalion

a. Pallium: general characteristics

LONGITUUINAL FISSURE OF CEREBRUNI-63:8

TRANSVERSE FISSURE OF CEREBRUII-63:9

SULCI OF THE CEREBRUAJ $-63: 13$

GYRI OF THE CEREBRUL- $63: 10$

GYRI PROFUNDI-63:11

GYRI TRANSIIIVI $-63: 12$

GRAY SUBSTANC: $-58: 5$

WIITE SUBSTANCE-58:4

PETROSAL IIPRESSION-63:14

LATERAL CEREBRAL FOSSA-63:15

LATERAL CEREBRAI FISSURE SYLVIAN $-63: 16$

POSTERIOR RAMUS-63:17

ASCENDING ANTERIOR RAMUS-63:18

HORIZONTAL ANTERIOR RANISS-63:12

The pa?.lium as a whole is subdivided into the following five lobes

and related fissures and sulci:

LATERAL CEPERPAL FISSURE [SYLVIAN]-63:16

CENTRAL SULCUS-63:30

PARIETO-OCCIPITAL FISSURE-64:12

COLLATERAL FISSURE-63:60

CIRCULAR SULCUS - $63: 25$

FRONTAL LOBE- $63: 33$

TEMPORAL LOBE-63:50

OCCIPITAL LOBE- $63: 63$

PARIETAL LOBE-63:70

INSULA $-63: 21$

b. Lobes of the cerebrum

FRONTAI LOBE $-63: 33$

FRONIAL POLE- $63: 34$

ANTERIOR CENTRAL GYRUS-63:31

PRECENTIAL SULCUS-63:35

SUPERIOR FRONTAL GYRUS $-63: 36$

SUPERIOR FRONTAL SULCUS $-63: 37$

MIDDLW FR.ONTAL GYRUS- $63: 38$

PARS SUPERIOR-63:39

PARS INFERIOR- 63:40

INFERIOR FRONTAL SULCUS- $63: 41$

INFERIOR FRONTAL GYRUS $-63: 42$

PARS OPERCULARIS $-63: 43$

PARS TRIAIYGULARIS $-63: 44$

PARS CRBITALIS- $63: 45$

STRIGHT GYRUS $-63: 46$

OLFACTORY SULCUS- $63: 47$

CRBITAL GYRI-63:48

ORBITAL SULCI- $63: 49$

PARIETAL LOBE-63:70

POSTERIOR CENTRAL GYRUS-63:32

SUPERIOR PAKIETAL LOBULE-63:71

INTERPARIETAL SULCUS- $63: 72$

IIIERIOR PARIETAL LOBULE- $63: 73$ 

SUPRAIAARGINAL GYRIS-63:74

ANGULAR GYRUS $-63: 75$

TEMPORAL LOBE-63:50

TEIAPORAL POLE-63:51

TRANSVRRSE TEMPORAI SULCI-63552

TRANSVERSE TEIPPORAL GYRI-63:53

SUPERIOR TEMPORAL GYRUS $63: 54$

SUPERIOR TEUPORAL SULCUS-63:55

MIDDLE TEIPORAL GYRUS- $63: 56$

MIDDLE TEMPORAL SULCUS- $63: 57$

INFERTOR TEMPORAL GYRUS-63:58

INFERIOR TENPORAL SULCUS-63:59

COLLATERAE FISSURE-63:60

FUIIFORM GYRUS $-63: 61$

LINGUA GYRTS-63:62

OCCIPITAL IOBE $-63: 62$

OCCIPITAL POLE-63:64

TRANSVERSE OCCIPITAL SULCUS-63:65

SUPERIOR OCCIPIIAL GYRI-63:66

SUPERIOR OCCIPITAI SULCI-63:67

LATERAL OCCIPITAL GYRT-63:68

IATERAL OCCIPITAL SULCI-63:69

INS ULA-63:21

OPERCUI,UN-63:26

PARS FRONTALIS $-53: 27$

PARS PARIETAIJIS- $63: 28$

PARS TIIPORAIIS- $63: 29$

GYRI IHSULAE-63:22

Fisosed by pulling apart the margins of the lateral fissure cutting avay a part of the operculum if necessary.

GYRUS LONGUS INSULAE-63:23

GYRI BREVES INSULAP- $63: 24$

SULCUS CENTRALTS- $63: 30$

SULCUS CIRCULARIS- $63: 25$

c. Medial surface of the hemisphere-63:76

SULCUS CORPORIS CALTOSI- 63:77

SULCUS CINGULI- $63: 78$

PARS SUBFRONTALIS-63E79

PARS MARGINALIS-64:1

SULCUS SUBPARIETALIS- $64: 2$

FISSURA HIPPOCAIPI-64:3

In the fiesura hippocampi the fascia dentata hippocampi-54:56, and the iimbria hippocampi-64:53, may be observed.

GYRUS FORNICATUS-64:4

GYRUS CINGULI-64:5

ISTHUUS GYRT FORNICATI-64:6

GYRUS HIPPOCAMPI-64:4

UNCUS $-64: 8$

SUBSTANTIA RETICULARIS ALBA-64:9

LOBULUS PARACENTRALIS-64:10

PRAECINU US- 64:11

FISSERA PARIETOOCCIPITALIS-64:12

FISSURA CALCARIIA-64:13

IUNEUS- 64: 14 

d. Rhinencephe 1 on- $64: 58$

SULCUS PAROLFACTORIUS ANTERIOR-64:59

PARS ANTERIOR-64:60

LOBUS OEFACIORIUS-64:61

BULBUS OLFACTORIUS $-64: 62$

TRACTUS OLFACTORIUS-64:63

TRIGONUAI OLFACTORIUI-64:64

STRIA MEDIALIS-64: 65

STRIA INTERIEDIA-64:66

AREA PAROLFACTORIA-64:67

SULCUS PAROLFACTORIUS POSTERIOR-64:68

PARS POSTERIOR-64:69

GYRUS SUBCALLOSUS $-64: 70$

SUBSTANTIA PERFORATA ANTERIOR-64:71

STRIA OLFACTORIA LATERALIS-64:72

LINEN INSULAE-64:73

e. Hypothalamus-62:24

PARS OPTICA HYROTHALAMI-62:27

Only the optic part of the hypothalamus is in relation to the telencephalon; the merillary part-62:25, includes the corpus ramillare-62:26.

TUBER CINEREUM-62:28

INEUNDIBULUN- $62: 29$

HYPOPHYSIS $-62: 30$

LOBUS ANTERIOR- $62: 31$

LOBUS POSTERTOR-62:32

TRACTUS CPTICUS $-62: 33$

RADIX IEDIALIS $-62: 34$

RADIX LATERALIS $-62: 35$

CHIASMA OPTICUM- $62: 36$

LAIIINA TERIINALIS-62:37

f. Corpus cal1 10sum- 64: 15 .

The corpus callosum be demonstrated by slicing off the upper part of the right hemisphere at the level of the sulcus cinguli (incidentally exposing the centrum semiovale-64:76), cutting transversely through the middle of the gyrus cinguli and carefully tearing away the anterior and posterior parts of the gyrus cinguli, exposing at the same time parts of the radiatio corporis callosi-65:6-11, and the cingulura $65: 2$.

SPLENIUN CORPORIS CALLOSI-64:16

TRUNCUS CORPORIS CALLOSI $-64: 17$

GENU CORPORIS GALLOSI-64:18

ROSTRUA CROPORIS CALLOSI-64:19

LAMIIIA ROSTRALIS $-64: 20$

STRIAE TRANSVERSAE-64:21

STRIA LONGITUDINALIS MEDIALIS-64:22

STRIA LONGITUDINALIS LATERALIS- $64: 23$

FASCIOLA CINEREA-64:24

g. Ventriculus lateralis $-64: 35$

The lateral ventricle may be exposed by making the following dissections: a) making a longitudinal incision through the corpus callosum about $1 \mathrm{~cm}$. from the medial sagittal plane, reflect lateralward and detach the part of the corpus callosum lateral to the incision, taking care to leave in situ the part of the corpus callosum medial to 



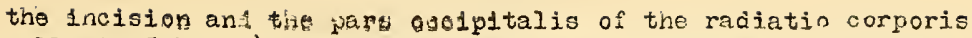
callosi-65:1n; b) cutting bankward and lnteralivard through the medullary substance forming the roof of the veutricular carity, romove enough of the rocf to expose the interior of the central part of the cavity; c) to open the inferior cornu extend the preceding incision downward and forward through the lateral part of the tomporal lobe towards the temporal pole, following the course of the cavity (whicil lies nearly parallel to the superior temporal sulcus), and remove the part of the temporal lobe superior to this incision together with the pars terporalis of the operculum-63:26, but guarding the insula froris injury.

CORNU ANTERIUS-64:37

CAPUT NUCLPI CAUDATI-64:42

PARS CENTRALIS $-64: 36$

NUCLEUS CA UDATUS-64:41

STRIA TERMINALIS $-64: 44$

TERIINAL VEIN-53:50

IANINA AFEICA-64:45

LANINA CHORIOIDEA EPTIHELIALIS-64:47

PIEXUS CHORIOIDEUS WENRICULI LATERALIS-65:62

TAENIA CHORIOIDEA-64:64

THALAMLS-62:52 Iargely covered by the chorioid plexus. TAENIA FORIVICIS-64:28

CORINU PCSTERITS-64:38

TAPETLI-65:11 With reference only to the roof and lateral wall of the posterior cornu.

CALCAR AVIS- $64: 48$

(BULBUS CORNU POSTERIORIS) $-64: 49$

CORIUU INEERIUS- $64: 39$

The mutual relations of the inferior cornu and the insula may be more thoroughly examined by insinuating the fingers beneath the pars frontalis and pars parietalis of the operculum-63:27, 28, and carefully tearing away the cortex in an upward direction. The following two structures are in relation to the inferior wall:

EIINENIIA CCLIATERALIS-64:50 Sometimes absent.

TRIGONUR COLLATERALE-64:51

The following structures are in relation to the lateral and superior walls of the inferior cornu:

TAPETUI -65:11

NUCLEUS ANYGDALAE-65:21

STRIA TERVIIVIIS-64:44

CAUDA NUCLEI CAUDATI-64:43

In relation to the medial wall the following structures may be observed:

HIPPOCAIAP US $-64: 52$

DIGITATIONES HIPPOCAIIPI $-64: 55$

FIIIBRIA HIPPOCANPI-64:53

CHORIOID PLEXUS $-65: 62$

TAENIA FIMBRIAE-64:54

h. Septum pellucidum, fornix and tela chnrioidea

The septum pellucidum and fornix are exposed by cutting through the occipital part of the radiation of the corpus callosum (of the right hemisphere) and through the fimbria hippocampi at the point where it passes into the crus fornicis, then carrying the knife anteriorly from the anterior end of the inferior horn, above the level of the uncus, 

through the tenporal pole, separating the temporal lobe, together with the hippocampal gyrus modial to it, from the remainder of the brain along the line of the transverse fissure of the cerebrum; finally paring away enougin of the cut edge of the medial part of tine corpus callosum necessary to satisiactorily demonstrate the septum pellucidum and fornix.

SEPTUM PELLUCIDUR-64:32

IAAINA SEPTI PELLUCIDI-64:33

CAVUH SEPTI PELLUCIDI-64:34

Exposed by cutting through the remaining modial part of the corpus callosum just posterior to the genu, carefully detaching it from the septum pellucidum and fornix and FORNIX-64:25 separating the two laminae of the septum.

CRUS FORNICIS-64:26

CORPUS FORNICIS $-64: 27$

TAEIVIA FORNICIS- $64: 28$

COLUARA FORIICIS- $54: 29$

PARS LIBERA COLURNAE FORNICIS $-64: 30$

PARS TECTA COLINRIAE FORNICIS-64:31

TELA CHORIOIDEA VENTRICUII TQRTII-65:60

Exposed by cutting transversely through the middle of the corpus fornicie, carefuliy raising the two parts of the fornix and reflecting them anterioriy and posteriorly, noting the commissura hippocampi-54:57, situated between the crura of the fornix.

INTERNAL CEREBRAL VEIIS-53:47

VEII OF SEPTUEA PELLUCIDUL-53:49

TERIIINAL VEII:-53:50

CHORIOID VEIN $-53: 52$

PLEXUS CHORIOIDEUS VENTRICULI LATERALIS-65:62

GLORUS CHORIOIDEU: $-65: 63$

PIFXUS GHORIOIDEUS VENTRICULI TERTII-65:61

Exposed by dividing the terminal vein at its junction with the internal cerebral vein, seizing the apex of the tela chorioidea and pulling it backwards exposing the cavity of the third ventricle, but guarding against injury to the attacinments of the corpus pineale-62:62

\section{Thalamencephalon-62:51}

a. Tha lamus $-62: 52$

PULVINAR $-62: 53$

TUBBRCULURA ANTERIUS THAIAII-62:54

TAENIA THALAMI-62:55

STRIA MEDULARIS- $62: 56$

LAIINA CHORIOIDEA EPITHELIALIS-62:57

i. Me tathàlamus-62:58

CORPUS CENICULATUI IEDIALE $-62: 59$

CORPUS GENICUIATUH LATERALE-62:60

c. Epithalamus-62:61

CORPUS PINEAIE $-62: 62$

RECESSUS PINEALIS-62:63

RECESSUS SUPRAPINEAIIS- $62: 64$

HABENULA- $62: 65$ 

COMISSURA HABRNULAFIR- $02: 65$

TRIGOINUN HABENULA $-62: 67$

3. Ventriculus tertius-82:14

ADITUS AD AQUAEDUCTUI CEREBRI-62:15

COHISSURA POSTERTOR-62:16

FORAMEN WEITRICULARE-62:17

SULCUS HYPOTHALANICUS-62:18

IASSA INTERIEDIA-62:19

RECESSUS OPTICUS-62:20

RECESSUS INFUNDIBULI- $62: 21$

COMIISSURA ANTERIOR-62:22

RCESSUS TRIANGULARIS $-62: 23$

\section{Brai: Sections through the Brain}

The mority of the structures to be observed in tained and unstained sections of the brain sequire a hand lens or microscope for their demonstration. These structures have not been repeated in detail here since they are given complete in part II, as originally listed in the $B \mathrm{NA}$.

1. Structures in secticn of the medulla oblenpata-59:29-57

Exposed in transverse sections made at (a) the level of the decussation of the pyramids; (b) between the decussation of the pyramide and the olives; and (c) through the middle of the olives.

2. Structures in sections of the pons $-62: 24-52$

Dexonstrated in transverse sections made at (a) about the junction of the pons and medulla, passing through point of entrance of the acoustic nerve; (b) at the level of the roots of the facial and abducens herves; (c) at the level of the roots of the trigeminal nerves, and (d) through the anterior medullary velum and tho middle of the pons.

3. Structures in sections of the cerebellum-61:10-24 Demon

Demonstrated in the following sections: a) a median sagittal section through the vermis; b) a frontal section through about the midaie of one half the cerebellum; and c) a horizontal section through the other half of the cerebellue in the plane of the brachius a conjunctivum.

4. Structures in sections of the powbencephalic isthrus and the.

$$
\text { mesencepha ion. }
$$

Demonstrated in iransverse sections made (a) timrough the inferior colliculus at the level of the nucleus of the trochlear nerve; and (b) through the superior colliculus and lateral geniculate body at the level of the roots of the oculoriotor nerve and the nucleus ruber. 

c. In sections of the corpora quadrigemina $=62: 7=11$

5. Structures in sections through the prosencephalon

For the fernonstration of these structures, horizontal sections about $\frac{1}{2}$ to $1 \mathrm{~cm}$. thick should be made through the remainder of the right cerebral hemisphere. In the left hemisphere, which should have been retained intact, either vertical frontal or obliquely frontal sections may be made.

The vertical frontal sections should pass through the following rajions: a) through the genu of the corpus callosum; b) through the septum pellucidum between the body and rostrum of the corpus callosum; c) through the tips of the temporal lobes; d) through the foramen interventriculare; e) through the corpora mamillaria; f) through the subthalamic region; g) through the upper end of the aquaeduc tus cerebri.

The bbliquely frontal sections should all be parallel to the sulcus centralis and pass through the following regions (in accordance with the method of itris, 1877): a) through the lobus frontalis about $5 \mathrm{~cm}$. anterior to the sulcus centralis; b) through the pars opercularis of the gyrus frontalis inferior and the corresponding portions of the gyrus nedius and gyrns frontalis superior; c) through the middle of the gyrus centralis anterior; d) through the middle of the gyrus centralis posterior; e) through the anterior ende of the lobulus parietalis superior and lobvius parietalis inferior; f) through the posterior part of the cerebrum about $1 \mathrm{~cm}$. anterior to the fissura parietooccipitalis.

In addition to the preceding horizontal and frontal sections, the following sections are especially instructive: a) through the brain in a plane passing parallel to the course of the brachia conjunctive and through them; and $b$ ) through the brain in a plane parallel to the course of the cerebral peduncles and through them.

\section{a. Sections of the hypothalamus $-62: 38-50$}

b. Sections of the thalamencephalon- $62: 68-73,63: 1-4$

c. Sections of the telencephalon-64:75-77, 65:1-31

\section{Organ of Vision.}

\section{Optic nerve-73:4 See also $x: 10 b$.}

VAGINAE N. OPTICI-73:5

SPATIA INTERVAGINALIS-73:6

2. Bulbus oculi-73:7

As a rule, the ordinary codaver material is not favorable for the present jurpose and mist consequently be supplemented by eyeballs obtained frora the ox or pig, in which the various structures may be demonstrated in both fresh specimens and in material hardened in formalin. The conjunctiva and fascia bulbi are caught with a forceps, cut through close to and entirely around the cornea and these structures together with any other soft parts removed from the surface of the sclera, and two hardened eyeballs cut into halves, the one by a sagittal and the other by a coronal section. 

ANTERIOR POLE- $73: 8$

POSTERIOR FOLE $-73: 9$

EQUATOR-73:10

INERIDIANS - 73:11

EXTEPNAL AXIS OF TYEBALL-73:12

INTERNAL AXIS OF EYEBALL-73:13

UPTIC AXIS-73:14

FINE OF VISION $-73: 15$

Ophthalmic vesicle $-73: 16$

Ophthalmic cup $\mathrm{x}-73: 17$

\section{Tunica fibrosa oculi-73:18}

\section{a. Sclera $-73: 19$}

Exposed by cutting through the sclera at the equator with a sharp knife and with a scissors carrying the incision completely around the eyeball along the line of the equator (carefully guarding against injury to the black chorioid coat); separating both parts of the sclera from the subjacent structures and reflecting the anterior part forwards, breaking the attachment of the ciliary muscle to its deep surface, and . separating the posterior part by dividing the fibers of the optic nerve in a plane corresponding to the inner surface of the sclera.

SULCUS SCLERAE-73:20

RIIAA CORNEALIS $73: 21$

SINUS VEINOSUS SCLERAE-73:22

LAMINA FUSCA-73:23

LAMINA CRIBROSA SCIERAE-73:24

(RAPHE SCLERAE) $-73: 25$

(FUNICULUS SCIERAE) $-73: 26$

b. Cornea $-73: 27$

ANIULUS CONJUNCTIVAE-73:28

VERTEX CORNEA

LIIBUS CORNEAE-73:30

FACIES ANTERIOR-73:31

FACIES POSTERIOF- $-73: 32$

The following structures can only be adequately demonstrated in thin sections by means of a hand lens and mirroscope.

EPITHEIUI CORNEAE-73:? $\therefore$

LANINA ELASTICA ANTERIOR-73:34

SUBSTANTIA PROPRIA $-73: 35$

LAIIINA FLASTICA POSTERIOR-73:36

ENDOTHELIUM CAIERAE ANTERIORIS-73:37

\section{Tunica vasculosa oculi-73:38}

a. Chorioidea-73:3:

LAMINA SUPRACHORIOIDEA-73:40

SPATIUR PERICHORIOIDEAIE-73:41

LAMINA VASCULOSA-73:42

The vorticose ve: $: 5-53: 60$, are exposed by brushin: away the pigmeat with a camel's hair brush.

LAUINA CHORIOCAPILLARIS $-73: 43$

LANINA BASALIS-73:44

(RAPHঙ CHORTOIDEAE) $-73: 45$ 

b. Corpus ciliare $73: 46$

CORONA CIIIARIS-73:47

Demonstrated by making a coronal section through an eyeball slightly anterior to the equator and carefully removing the vitreous humor from the anterior segment of the eyeball. PROCESSUS CILIARES $-73: 48$

PLICAE CILIARES $-73: 49$

ORBICULARIS CILIARIS $-73: 50$

CILIARY MUSCLE-73:51

The following fibers require a microscope for thei:

adequate demonstration:

FIBRAE MERIDIONAIES-73:52

FIBRAE CIRCULARES $-73: 53$

PLEXUS GANGLIOSUS CILIARIS-73:54

c. $\operatorname{Iris}-73: 55$

Exposed by cutting around the sclerocorneal junction and removing the cornea, making several meridional incisions through the anterior part of the sclera; the strips of sclera may then be separated from the ciliary muscle, bent asile and pinned to the bottom of a corklined tray filled with water, the iris examined and then removed for a more complete demonstiation of its structure.

MARGO PUPIIIARIS $-73: 56$

MARGO CILIARIS-73:57

FACIES ANIIRIOR-73:58

FACIES POSTERIOR-74:1

ANNULUS IRIDIS IWAJOR-74:2

ANNULUS IRIDIS NINOR-74:3

PITCIE :AIDIS-74:4

PUPILIA-74:5

SPHINCTER NUSCLI OF PUPIL-74:6

STROMA IRIDIS $-74: 7$

DILATCR MUSCLE OF PUPIL-74:8

PECTINATE LIGANEIVT OF IRIS-74:9

SPATIA ANGULI IRIDIS-74:10

GREATER ARTERIAL CIRCLE-74:11

LESSER ARTERIAL CIRCLE-74:12

(IEMABRANA PUPILIARIS) ${ }^{x}-74: 13$

d. Ciliary nerves and vessels

SHORT CILIARY NERVSS-66:37

LONG CILIARY NERVES-66:25

SHORT POSTERIOR CILIARY ARTERIES $-47: 75$

IONG POSTERIOR CILIARY ARTERIES-47:76

ANTERIOR CILIARY ARTERIES-48:1

VENAE VORTICOSAE-53:60

\section{Pigment layer $-74: 14$}

Exposed by removing the choricidea under water.

STRATUM PICNENTI RPTIIJE-74:15

STRATUI PIGUENTI CORPORIS CIIIARIS-74:16

STRATUM PGIMEITI IRIDIS-174:17

\section{Retins-74:18}

Exposed by removing the chorioidea from eyegall from witis the 

sclera and cornea have already been taken away.

PARS OPTICA RETINAD-74:I9

ORA SERRATA-74:20

PARS CILIAEIS RETINAE-74:21

PAPILLA N. OPIICI-74:22

EXCAVATIC PAPILLAE N. OPIICI-74:23

WACULA LITTEA-74:24

FOVIA CENTRALIS-74:25

VASA SANGUINAA RETINAE-74:26-34

liay be examined in the living eyo with the ophthalnoscope.

\section{Vitreous body $-74: 38$}

Obtained from an eyeball which has been kept for several days without preservatives, by dividing the coats of the eye at the equator, carefully turning back the cut edges and allowing the "eye-zernel" (vitreous body and crystalline lens) to slip out into a vessel of water; the demonstration of the hyaloid membrane, capsule of the lens, and the zonula ciliaris may also be facilitatad by staining for a few minutes in strong picrocarmin solution and vashing in water. HYALOID ARTERYX $-74: 39$

CANALIS HYALOTDEA $-74: 40$

FOSSA HYALOIDEA $=74: 41$

IEEIBRANA HYAIOIUEA-74: 42

STROIIA VITREUHA-74:43

HULOR VITREUS $-74: 44$

\section{Zonula ciliaris $-74: 59$}

FIBRAE ZONULARES-74:60

SPATIA 20NULARIA-74:61

Their structural characteristics may be demonstrated by inserting the point of a fine blow-pipe into the spaces and inflating them with air.

\section{Crystalline lens $-74: 45$}

Isolated for observation by cutting through the zonular ribers of the zonula ciliaris and removing the lens.

CAPSULA IENTIS-74:51

POLUS ANTERIOR IENTIS- $74: 52$

POLUS POSTERTOR LENTIS $-74: 53$

FACIES ANTERIOR LENTIS-74:54

FACIES POSTERIOR LENTIS-74:55

AXIS LENTIS-74:56

AEQUATOR LENTIS-74:57

RADII LENTIS $-75: 58$

SUBSTANITA LENTIS-74:46

Exposed by cutting through the anterior wall of the capsule and pressing the lens out through the oparing.

SUBSTANTIA CORTICALIS-74:47

NUCLEUS LENTIS-74:48

With the aid of a microscope the following structures nay be demonstrated in a lens which has been hardered in alcohol and teased apart. FIBRAE LENTIS-74:49

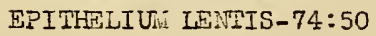

10. Chambers of the eveball

CAMERA OCLLI ANTERIOR-74:35

ANGULUS IRIDIS $-74: 36$

CAIERA OCULI POSTERIOR-74:37 

A B D O $\mathrm{IN}$ AN D PELVIS

$\ldots \ldots \ldots$ 



\section{AEDOMEN AND PELVIS}

\section{Cenerd Characterietics}

1. Subdivisions of abdomen and pelvis

ABDONEN $\triangle 4: 55$

ABDCMCNAL CAITTY-4:56

SCPUBTCUTJUS CORDIS $-4: 57$

UNBITICUS $-4: 58$

FLANK $-4: 59$

LOTN=4:60

GROIN.4: 61

PELVIS- 5:1

PEIVIC CAVITY $-5: 2$

IONS PUB IS $-5: 3$

HJ.P $-5: 4$

BU:TOCK-5:5

ANUS $-5: 6$

$$
\text { BNAT CIEFT-5:7 }
$$

PERINGU $: 5: 8$

\section{Surface anatomy}

XIPHOID PROCESS $-7: 52$

RIBS-7:28 Anterior ends of 7 th to 12 th riba.

ILIAC CREST-15:18

POSTERIOR SLPERIOR ILIAC SPINE-15:24

CRISTA SAGRALIS IEDIA-7:18

ANTERIOR SUPERIOR ILIAC SPINE-15:22

INGUINAL LIGAIIENT-2 5:41

SUPERIOR RANUS OF THE PUBIC BONE-15:50

SYMPHYSIS PUBIS $-15: 53$

PUBIC TUBZRCLE-15:44

LINEA ALBA-25:34

LINEA SEITLUNARIS-2 5:49

SUBCLTANIOUS INGUINAL RING-2 5:44

SPERTAIIC CORD $-40: 37$

ROUND LIGAMENT OF THE UTERUS-42:23 In the female.

TUBZR ISCHIADICUI $-15: 36$

INFERIOR RANUS OF THE ISCHIUM-15:35

3. Regions

EPIGASTRIC REGION-83:15

HYPOCHONDRIAC REGION-83:16

证SCCASTRIC REGION-83:17

UNIEIIICAL REGION-83:18

LATERAL ABDONINAL RECION-83:19

HYPOGASTRIC REGION-83:20

PUBIC REGION-83:21

INGUINAL REGION-83:22

Regions of the back in relation to the pelvis:

PERINEAL REGION-83:33

ANAL REGION-83:34

UROGENITAL REGION-83:35

PUDENDAL RHGION-83:36 



\section{Perineal region}

1. Surface anatomy

a. Perineal region in general

SWURHYSIS FUBIS-i5:53

ARCTJATS LICAMENT-20:61

COCCYX $-7: 25$

INEERIOR FANUS OF THE PUBIS-15:49

INDSRIOR RAMUS OF THE ISCHIUI $-15: 35$

SACROTUEGRCUS LIGANENT-20:49

PERINEAL RAPHE $-43: 18$

b. Pudendal region in the male

CORPUS PEIIS. $40: 68$

DORSTI OF PENIS -40:70

URETHRAL SURFACE $-40: 71$

GLAINS PENIS-40:72

CORONA GLANDIS $-40: 73$

SEPTUR GLANDIS $-40: 74$

COLLUR CLANDIS $-40: 75$

PREPUCE $-41: 1$

FREIULUN OF PREPUCE-41:2

EXTERNAL URETHRAI, ORIFICF $-41: 28$

SCROTUM $-41: 31$

RAPHE OF SCROTUM-41:32

$\frac{\text { c. Pudendal region in the ferrale }}{\text { liONS PLBTS-5:5 }}$

FEMALE PUDENDU $-42: 45$

LABIUI MAUS PUDEIDAE-42:46

ANTERIOR LABIA CONIHISSUPE $-42: 47$

POSTERIOR IARIAL COMAISSURE $-42: 48$

FRENULUA OF PUDENDAL LABIA-42:49

RIMA PUDENDI-42:50

FOSSA NAVICULARIS $-42: 51$

LABIUER IITIUS PLDENDI-42:52

VESTIBULWI VAGINAE-42:53

ORIFICIUU $V A G I N A E-42: 57$

CLI T: : $:=42: 59$

CORPUS CLITORIS-42:61

GLANS CLITORIS- $42: 62$

EXIERNAL ORIFICE OF URETHRA-42:71 PREPUCE OF CLITORIS- $42: 54$

HXVEN-42:29

HYRAN CARUNCLES-42:30

2. Urogenital region: Structures external to the urogenital diaphragm

a. In the male

Skin incisions (The body being in the Iighotomy position): a) transversely between the anterior extremities of the ischial tuberosities; b) median along the median raphe from the sacrum to the tip of the coccyx, encircling the anus.

SUPERFICIAL PERINEAI FASCIA-43:45

The folloving structures in the compartment between the supericial perineal fascia and the urogenital diaphragm are exposed by making 

ar incision through the deoper layer of the superficial perineal fascia, beginning in the median line at the base of the scrotum and extending to the ischial tuberosity on each side, and reflecting the fascial flaps.

SUEEP ICIAI TRANSVERSE PERIIERL MUSCIE-43:42

ISCHIOCAVERNOSUS MUSCLT- $43: 43$

BUJ_BOCAVERTOSUS MUSOTE- $43: 44$

PERIIEAL ARIERY-53:19

POSTEIOR SCFOTAL ARTERIES-51:20

PERIIEAT, NHEVE-7I:2I

PCSTERIOR SCROTAL IERVES-71:22

PEETREAL RIII OF THE POSTYRIOR FEMORAI CUTANEOUS NERVE-70:53

LIRPHATEC VESSELS

ROOT OF PEITS $-40: 67$

CRLRA OF PMIIS $40: 69$

CORP.JRA CA VERNOSA PEIIIS-4I:4

The 10llowing stuctures are exposed by dividing the bulbocavernosus muscle in the midine and reflecting the muscle.

CORPUS CAVERNOSU. URETHRAF-4i=5

BUIBUUS URETHPDE-4I:6

HEIISPITRES OF EULE OF UPETHRA-41:7

SEPMUM OF BULB OF URE THRA-41:8

b. In the female

Skin incisions (The body being in the lithotomy position): a) transversely beiween the ischial tuberosities; b) along the median line extending from the mons pubis to the tip of the coccyx, encirciing the labia majora and the anal orifice.

SUPERFICIAL PERINEAL FASCIA-43:45

PERIMEAL ARTEFY-51:19

POSTERIOR IA.EIAL ARTERTES-5I:21

PERIIEAL AERVE-71:21

POSTERIOR IABIAI IERVES-71:23

PERTINAL RANI OF THE POSTERIOR HEMORAL CUTAIEOUS NERVE-70:53

LIMPHATIC VESSELS

SUPERFICIAL TRAIISVERSE PERINEAL MUSCLF-43:42 Not contant in degree of development.

ISCHIOCA VEENOSUS WUSCLE-43:43

BULBOCA VERNOSUS HUS OL $-43: 44$

The folloring structures are exposed by reflecting tinc bulbocavernosus and ischiocavernosus muscles.

BULBUS VESTIBUII-42:54

TLANDULA VESTIBULAPIS NAJOR-42:58

CRURA CLITORIDIS-42:60

CORPUS CLITORIDIS $-42: 61$

CORPORA CA VERTOSA CLITORIDIS-42:66

SEPTUM CORPORUI CAVERIVSORUM-42:67

FASCIA CLITOR $-D I S-42: 68$

CLANS CLITORIDIS $-12: 62$

3. Urogenital diaphragm

a. In:erior fascia of tine urogenital diaphragm-43:37

Exposed by detaching the ischiocavernosus muscie and the crus

penis (the crus clitoridis in the case of the female) from the

puoic arch on each side; guarding against injury to the

inferior fascia of the urogenital diaphragm, branches of the 

Internel pudendal artery and the doreal nerve of the penis (or

the clitoris in the female).

The inferior fasnia of the urogenital diaphragm is removed in exposing the following structures situated in the compartment between the inferior and the superior fascia of the urogenttal diaphragtn.

b. Structures in the Uroganital diaphragm in the male

TRANS VIRSE PERINEI PROFUNDUS MUSCLE-43:34

SPHINUNER URETHPAE MEIBRANACEAE MUSCLE-43:35

ARTERY OF THE PENIS-51:22

ARTERY OF THE BULB OF URETHRA-51:24

URETHRAL ARTYSTY-5I:23

DEEP ARTERY OF PENIS-5I:26

DORSAL ARTERY OF PENIS $-51: 27$

DORSAL VEIN OF THE PENIS-55:49

DORSAL NERVE OF THE PENIS-71:24

BULBOURETHRAL GLANDS $-40: 62$

BODY OF GLAND $40: 63$

EXCRETORY DUCT-40:64

MEMBRANOJS PARI OF URETHRA-41:24

SUPERIOR FASCIA OF UROGENITAL DIAPHRAGH $-43: 36$

The folloving structures are in relationship to this

fascia:

ARCUATE IIGANENT OF THE PUBIS-20:61

TRANSVERSE LIGAIENT OF THE PELVIS-43:38

2. Structures in the Urogenital diaphragm ir. the femele

TRANSVERSE PERINEI PROFUNDUS ITUSCLE $-43: 34$

SPHINCTER URTIHRAE MEMBRANACEAE MUSCLE-43:35

ARTERY OF CLITORIS-51:28

ARTERY OF BULB OF VESTIBULI-51:25

URETHRAL ARTERY-51:23

DEEP ARTERY OF CLITORIS-51:29

DORSAL ARTERY OF CLITORIS-51:30

DORSAL VEINS OF THE CIITORIS-55:51

DORSAL NERVE OF THE CLITORIS-71:25

GLANDULA VESTIBULARIS MAJOR-42:58

URETHRA-42:70

SUPERIOR FASCIA OF THE UEJGENITAL DIAPHRAGM-43:36

The following structures are in relationship to this fascia: ARCUATE LICAMENT OF THE PUBIS-20:61

TRANSVERSP IIGANENT OF THE PELVIS-43:38

4. Anal region

SUPERFICIAL PERINEAL FASCIA-43:45

SPHINCTER AND IXTERNUS IUUSCIE-43:34

ANOCOCGYGEAL LIGAIENT-43:25

ISCHIORECTAL FOSSA $-43: 41$

The fat in the ischiorectal fossa is removed in the demonstration of its contents.

INFERIOR HAEMORRHOIDAI NERVE-72:20

INFERIOR HAEMORRHOIDAI ARTERY $-51: 18$

The following structures are in relationship to the walls of

the fossa:

INFERIOR FASCIA OF PELVIC DIAPHRAGM-43:32

LEAVTOR ANI MUSCLE-43:21

OBTURATOR FASCIA-43:40 


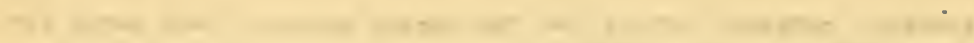

1

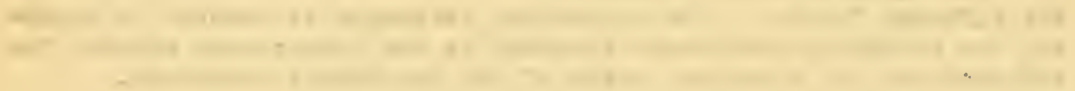

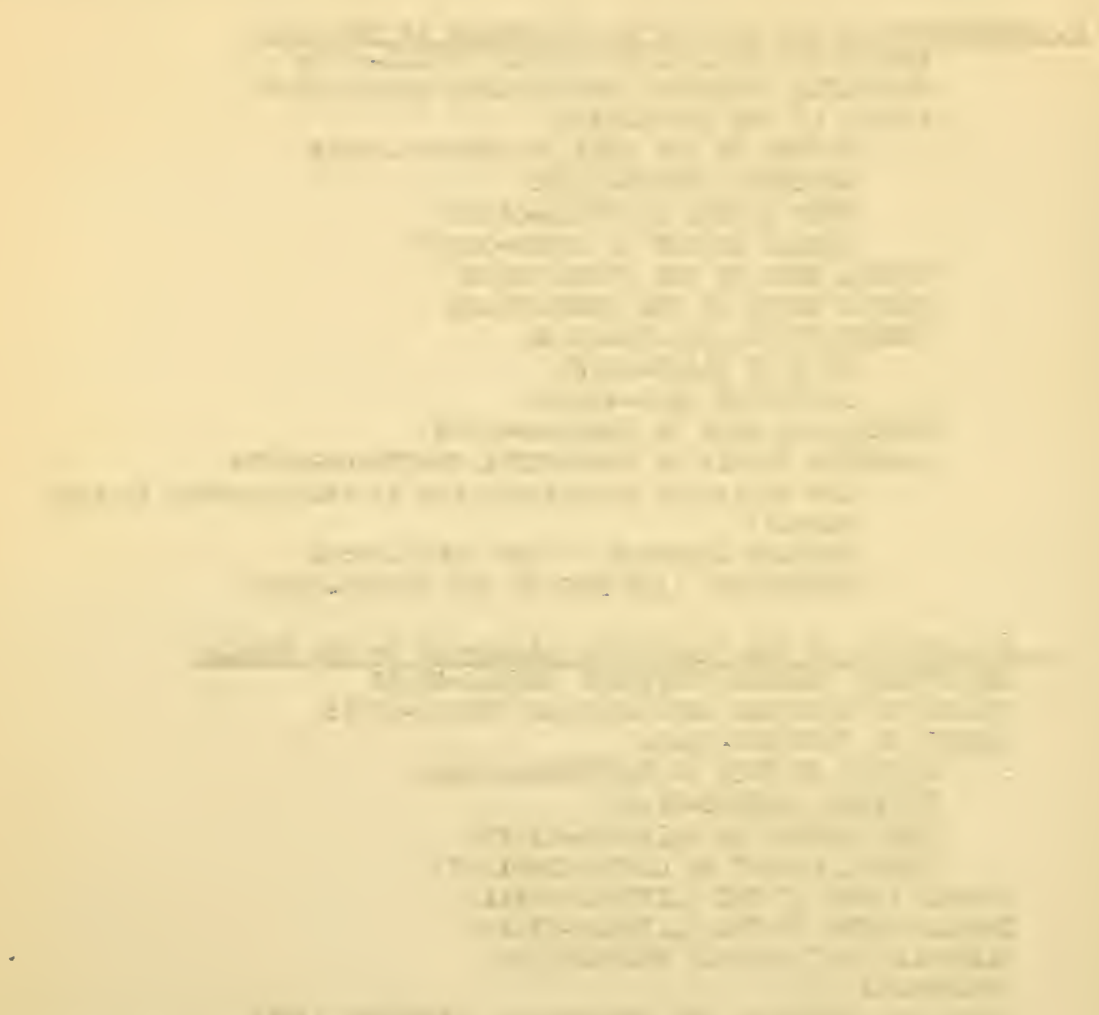

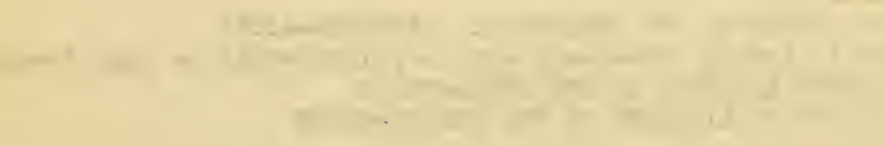

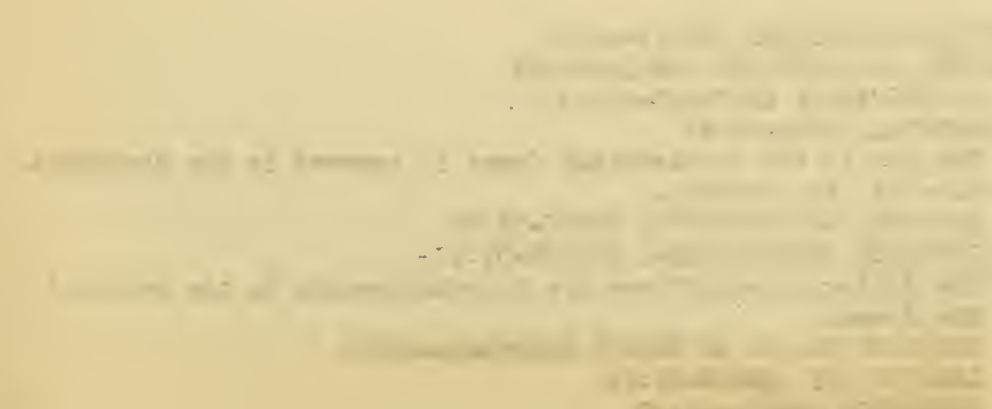


Tha igllowing netre prat arter: are in relatios, to the outurator iascia:

PUUEINDAI NERVE-71:I9

INIERIIAL PUDENDAL ARIERT-51:I7

TEDDINOUS ARCH OF DIE LEAVTOR ANI WUSOLE- $\$ 3: 22$

Situated at the arigle of junction of the ooturator

fascia and the inferior fascia of the pelvic

diaphragm.

OBTURATCR INIERIIUS MUSCLE-26:72

UROGENITAL DIAPHPAG:-43:33 Its posterior margin only.

GLUTAEUS MAXINUS MUSCLE-26:67 Its posterior or disteI margin only.

SACROTUBEROUS LIGAIENT-20:49

\section{Anterior Abdominal Wall}

1. Fascia, cutaneous nerves and blood vassels

For the surface anatony of the abdomen, see I:2.

Skin incisions: a) Iongitudinelly along the anterior median line from the xiphoid process to the mons pubis (encircle the umbilicus; b) from the xiphoid process transversely around the thorax as far back as possiole; c) from the mons pubis laterally along the line of the inguinal ligament to the anterior superior iliac spine and then posteriorly ajong the iliac crest as far back as oossible.

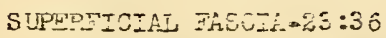

Divided into two layers toward the inferior part of the abdomen.

ANTERIOR CUTANEOUS RAMI OF INTERCOSTAL NERVES-70:8

ANTFRIOR CUTAIEOUS RAMUS OF ILIOPHYPOGASTRIC IERVE-70:28

ILIOINGUINIL NERVE-70:29

LATERAL CUTANEOUS RANI OF INTERCOSTAL NERVES-70:3

LATERAL CUTANEOUS RAMUS OF THE ILIOHYPOGASTRIC NERVE-70:27

SUPERFICIAL IPIGASTRIC ARTERY-5I:39

SUPEPFICIIL CIRCIMFIEX ILIAC ARTERY-51:40

EXTERNAL PUDENDAL ARTERIES-51:41

PARUMBILICAL VEIISS $-55: 36$

THORACOEPIGASTRIC VEINS-54:32

SUPERFICIAL EPIGASTRIC VEIN-55:65

\section{Deeper structures o: the anterior abdoninal ral I}

a. Muscles and related structures

OBLIQUUS EXTERUTUS IEDONIIIS ITUSCLA $-25: 28$

Exposed by the removal of the deep fascia, guarding at the same time against injury to its aponeurosis and the structures in relation to the subcutaneous inguinal sing.

The following structures are in relationship with the external obiique muscle:

TRIGONUTI LU:UBAIE-25:48

INGUINAI LIEGINENT-25:41

LACUTAR IIGANDINT-25:42

SUBCUTANEOUS INCUINAI RING-2 5:44

SUPERIOR CRUS-25:45

INFERIOR CRUS-25:46

TNTGRCRITAI, FTRERS-25:47 

ORLIQUUS LUTMUUUS ABDONINIS MUSCLR-25:29

Exposed by detaching the external nblique nuscle at its origin, iividing the muscle at its insertion into the iliac crest, from the superior iliac spine carrying an incision meacialward through the aponeurosis of the external oolique muscle to the lateral nargin of the rectus abdominis muscle, and reflecting the external oblique muscle medialward.

CREMASTERIC UUSUIE-25:30

FAIISVEPSUS ABDONIIIS MUSCLE-25:31

Bxposed by detaching the internal oblique muscle at its origin and reflecting the miscle toward its insertion, at the same time guarding the subjacent nerves and vessels, and leaving intact the inguinal canal and its contents.

IINEA SENILUIARIS-25:49

The following nerves and vessels are in relationship throughout part of their course with the internal oblique and transversus abdominis muscles.

AITERTOR RA:II OE THORACIC NARVIS-70:1

IIIOFYPOGASTREC IERVE-70:25

ILIOINGUIINAI INEPVE-70:29

INTERCOSTAL ARTERTES $-49: 59$

LUNBAR ARHEPIISS-50:8

RECIUS ABDONIIIS NUSCLE-25:25

Pxposed by reking a Iongitudinal incision through the

aocneurotic sheath of the rectus abdcmiris muscle at $=$ distanco of about $3 \mathrm{~cm}$. from the linea alba, the inferior end of each incisian curving tomard the symphysis pubis.

TENDINOUS INSCPIPTIONS $-23: 37$

SHFAIH OF TFE FECWUS ABDONINIS MUSCLE-25:39

LIIEA STMTCIRCULARIS-25:40

the following arteries are in relationship to the rectus sheath:

INWRIOR PPIGASTRIC ARTERY-51:32

SUTERIOR FIPICASTRIC ARTHRY-48:47

PYRAIIDALIS TUSCIE-25:27

LINEA ALBA-25:34

FASCIR TRAITVVRSAIIS-25:50

DEWP CIRCTMIFIEX ILIAC ARTERY-51:37

PERTIOREUL: $-43: 46$

Expoeed oy the removal of a small portion of the fascia

tranerersalis.

b. Internal surface of the anterior abdominal wall

Exposed by beginning at a point fust above the umbilicus making three incisions through e.jominal wall, two of tiem extending to the anterion superior iliac spine on each side, and the third passing to the right of the urabilicus and $2 \mathrm{~cm}$. to the right of the Iinea alba ond terminating at the superion ramus of the pubic bone. URACHUS-39:34

PLICA UUBILICAIISINIDIA-44:22

PLICA UDEILICAIIS LATERALIS-44:23

PLICA EPIGASTRICA-44:24

FOVEA SUPRAVESICAIIS $-25: 57$

FOVEA INCULIALIS MIDIA-25:56

EOVEA INGUITAIIS LATRALIS-25:55

SBDONENAL INGUINAL RING-25:5? 

3. Inguinal canaI, scrotum spermatic cord and testis

a. Inguinal canal-2 5:51

A demonstration of its boundaries involves the removal of the peritoneum from the anterior abdominal wall in the region of the inguinal cans.l.

FAIX INGUTNAIIS-25:26

REFLEX INGUINAT, LIGAIENT-25:43

b. Scrotum and spersatic cord

SCROTH $-41: 21$

The scrotal sac is opened and its contents exposed by making a longitudinal incision through the anterior wall of the scrotum on each side of the mid-line.

RAPHE OF THE SOROTUU-41:32

SPPTLI OF THE SCROTUM-41:33

TLNTCA DARTOS $-41: 34$

SPERIIATIC CORD $40: 37$

CREIASTERIC FASUIA-40:47

CRIIASTERIC NUSCLE $-40: 46$

(VAGINAL PERITONEAL PROCESE; $-40: 38$

TUNICA VACTIALIS CONAUNIS-40:45

DUCTUS DEFTRENO..40:21

INIERIAL SPEDAATTC ARTERY-50:52

EXTERNAL SPERMATIC ARTERI-5I:35

DEERRIIIIAL ARTERY -51:1I

PAPPINIFORAI PLEXUS OF VIINS-5E:14

SPERUIATIC VEIN-55:11

EXTERIAT, SPERMATIC NERVE-70:35

DRERRYITAL PIEXUS-72:42

LYMPHATICS

c. Testis-39:56

TUNICA VAGTNALIS PROPRTA TESTIS-40:39

IAIIINA PARIETAIIS-40:40

LAJIINA VISCERALIS-40:41

SINUS פPIIIDYIIDIS-40:44

In exposing the testis an incision is made through the anterior part of the lamina parietalis of the tunica vaginalis propria.

SUPERIOR AND INFERIOR FXXREMITIES OF THE TESTIS-39:67, 68

LATERAI, AND NEDIAL SURFACES-39:69, 70

ANTERIOR AID POSTERIOR MARGINS-39:71, 72

EPIDIDYNIS-40:9

RAD, BODY AND TAIL OF SPIDIDYIIS-40:10-12

APPENDIX TESTIS $-40: 18$

The following structures may be identified in crass section of the

testis:

TENICA ALBUGINEA-39:73

IEDTASTINUI TESTIS - $9: 74$

SEPTULA TTSTIS-39:175

LOBULES-40:1

PAREITCHYSA-40:2

For the structures of the penis see $I I: I n, 2 a$ and $V=: 3 a$. 



\section{Abdominal Cavity. Peritoneum and Viscera}

1. Abdominal cavity and the peritoneum

a. General characteristics of the abdominel cavity, viscere and

$$
\text { reritoneum }
$$

In completing the opening of the abdominal cavity and demonstrating the abdominal and peritoneal relations of the following structures, the incision already made tinrough the lower part of the anterior abdominal wall (III:2b) is extended upward from the umbilicus to the riphoid process, passing just to the left of the mid-sagittal plane. LIVER-34:43

STORACH $-32: 78$

GALL BLADDER-35: 6

GREATER ONENTUR-43:70

SMALL INTESTINE $-33: 29$

LARGE INIESTINE-33:61

LESSER ONENTUR-43:64

PERTTONE UN $-43: \div 6$

PARJETAL PERTTONEUM-43:49

VISCERAL PERTTONEUR $-43: 50$

PERITUREAT, CAVITY $-43: 51$

b. Peritoneal folds and fossa in relation to the small and large

MESENTERY $-43: 53$

$$
\text { intestine }
$$

ROOT OF LESENTERY $-43: 54$

DUODENOJE JUNAL RECESS-44:9

DUODENOJE JTNAL FOLD-44:10

GREATER OMENTUM-43:70

MESOCOLON $-43: 56$

TRANSVERSE IIESOCOLON $-43: 57$

ASCENDING NESOCOLON $-43: 58$

DESCENDING MESOCOLON-43:59

SIGNOID IESOCOLON $-43: 60$

MESORECTUM $-43: 61$

INESENTERY OF THE VERMIFORM PROCESS-43:62

ILEOCAECAL FOLD $-44: 15$

SUPERIOR ILEOCAECAL RECESS-44:13

INFERIOR ILEOCAECAL RECESS-44:14

CAECAL FOLD $-44: 18$

CAECAL FOSSA-44:16

RETROCAECAL RECESS-44:17

PARACOLIC RECESS-44:19

PHRENICOCOLIC LIGAMENT-44:1

c. Peritoneal ligaments in relation to the liver, stomach and spleen

FALICIFORN LIGARENT OF LIVER $-44: 3$

LIGAMENTUL TERES OF THE LIVER-34:56

CORONARY IIGAIRENT OF THE LIVER-44:4

RIGHT AND LEFT TRIANGULAR LIGAMENIS-44:5, 6

LESSER OUIENTUR $-43: 64$

HEPATOGASTRIC LIGAMENT-43:65

HEPATODUODENAL IIGAIIENT-43:66

GASTROSPLENIC IIGANEMT-43:58

PHRENICOSPLENIC LIGAIENT-44:2 

d. Omental vursa- $-3: 71$

FORAIEN FPIPI,OICUI $-43: 77$

The extend and following subdivisions of the omental bursa may be exposed by inserting the finger tinrough the foramen

epiploicum:

VESTIBULT OF BURSA-43:72

SUPRRTOR OIENTAL RECESS $-43: 73$

TINERTOR OINITAL RECESS-43:74

SPLENIC RECESS $-43: 75$

e. Relations of the peivic peritoneum

RECTOVESICAI EXCAVATION OR POUCH- $44: 38$

PUBOVESTCAL FOLD $-44: 25$

TRAISVERSE VESICAL FOLD-44:26

The following structures relate to the female pelvis only:

BROAD LIGAIENT OT TIE UTERUS-44:29

RECTOUTERINE EXCAVATION OR POUCH-44:36

VESICOUTERIIE EXCAVATION OR POUCH $-44: 37$

f. Peritoneal relations in general

The relations of the peritoneum in general may be traced in cross and sagittal sections of the abdomen, Some of the peritoneal relations of such retroperitoneal organs as the kidney, duodenum and pancreas may be determined by palpation.

2. Mesenteric blood vesseis, nerves and lynphatics

SUPERIOR IESEMPEIC ARTERY $50: 36$ Not including its origin. Exposed by removing the right layer of peritoneum of the mesentery, the inferior layer of the transverse mseocolon, and the peritoneum of the posterior abdominal wall between the root of the mesentery and the ascending colon.

INTESTIPAT ARTERTES-50:37

JE JUNAL ARTERIES-50:39

IEEAI ARTERIES-5n:4C

INFERIOR PANCREATICODUODENAL ARTERY-50:38

ILEOCOLIC ARTERY $-50: 41$

APPEUDICULAR ARTERY-50:42

RIGHT COIIC ARTEPY $-50: 43$

IIIDDLE COLIC ARTERY-50:44

SUPERIOR NESEIVITRIC VEIN-55:I7

The tributaries of the superior mesenteric vein-55:18-25,

consist of vessels corresponding to the branches of the superior mesenteric artery, together with veins from the stomach and pancreas.

SUPERTOR INEEINTERIC STUPATHETIC PLEXUS-72:32

MESEITTERIC LYMPH GIAT:DS-56:64

DESOCOLIC LYMPH GLANDS $-56: 65$

INFERIOR INSENMERIC ARTERY-50:45

Demonstrated by removing the peritoneui from the posterior

abdominal wall between the root of the mesentery and the

descending and iliac colon.

LEFT COLIC ARTERY $-50: 46$

SIGMOID ARTERIES - 50:47

SUPERIOR HAEMORRHOIDAL ARTERY-50:48 Exclusive of $i$ is

termination. 

INFERIOR LASENTERIC VIIN-5 $5: 26$

LEFI COTIC VEIN-55:2,

SICLOTI VEINS - $55: 28$

SUPERTOR IAATIOREHOJDAL WEIN-55:29

Jarticlaes in an imporiant anastomosis between the systemitic and portal circulation.

INFERITR MESFNIERIC SYIPATIETIC PLEXUS-72:35

3. Nesenterial sma: I intestine and the large intestine

a. Mesenterial sma 11 intestine-33:58

J $J_{1} U_{1}=33.59$

ILEUVI- $33: 50$

The following structures can best be demonstrated in the intestine which hes heen removed from the abdomen, opened along its mesenteric border and its contents washed out. For its removal, the small intestine my be divided between ligatures about $5 \mathrm{~cm}$. below the duodenojejunzi flexure and about $10 \mathrm{~cm}$. above the iloccaecal junction, and jts connections serered with the mesentery and mesenterial blood vessels.

TUNICA SERTS-2 $-33: 30$

TUNICA MUSCTYARI-R - 33:31

LOJTOUOTAT, TAYER-33:32

CIECUI AP I ILTR.33:33

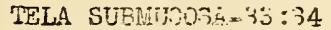

TUNICA IVLNOS $-3.3 \div 35,36$

PLICAE CTKCU APGS $33: 37$

INTSSTMAJ VIII-33:38 Demonstrated with a hand lens.

INTESTINAL GiANDS $33: 40$ Demonstrated with a hand Iens.

AGGREGATED INRPA INUTUTSS-33:41

SOLITARY IIMPPF NODULES-33:40

CHYNE-3:3: 3

CHYL画-?: $2: 3$

INLESTINAE JUICE $-33: 44$

b. Large intostiner33:6I

CARCUT- $0: 23$

VERIFOERI PROCESS-33:67

COLON-33:70

ASCEITING COION-33:71

RIGHI COLIC FIIDXIJRE $-33: 72$

TRANSVERST COTCN $33: 73$

LEET COLIC FLPYIURE: $=33: 74$

DESCENDING COION-33:75

SIGIOID COI,ON-33:76

TAENIAE COLI-33:82

TAENIA IESOCOLICA-34:1

TA.EIA ODENTALIS-34:2

TAENIA LIBEFA-3 $3: 3$

HAUSTRA $U O T I-33: 73$

APPENDICES EPIPLOICAE $-33: 80$

The following structures can be demonstrated to best advantage after the large intestine has been divided between ligetures at the junction of the sigmoid colon with the rectum, removed from the abdomen and its contents mashed out.

VALVULA COT:-33:63

INFERIOR AND SUPFRIOR LIPS-33:64, 65

FRENULA OF THE VALVE OF THE COLON-33:66 

(VALVE OF TY VERUIFORI PROCESS) - $33: 68$

AGGREGATED NODULES OF THE VERIIFORM PROCESS-33:69

TUNICA SEROSA-33:79

TUNICA WUSOULARIS-33:81

TUNICA SUBIUUCOSA-34:4

TUNICA HUCOSA $-34: 5,6$

INTESTINAL GLANDS $-34: 7$

SOLITARY LYLPHATIC NODULES $-34: 8$

4. Structures in relation to the walls of the omental bursa

a. Biliary ducts and vessels in the lesser omentum

The exposure of the structures in thelesser omentum may be facilitated by the removal of the greater part of the left lobe of the liver. To this end an incision may be made through the left lobe in an anterior-posterior direction, beginning just at the left of the falciform ligament and terminating near the left margin of the fossa for the ductus venosus (keeping the detached part of the liver Trapped in a damp cloth for later siudy).

CORMION BILE DIJCF 35:16

HPPATTC DLCT.35:3

SYSTIC DUCT.35:10

PORTAL VETNT 55:15

HEPATIC ARTERY $=50: 19$

RIEHT GASTRIC ARTERY-50:20

PROPER HEPATIC ARTEPY-50:2I

RIGLI RAMUS $-50: 22$

SYSTIC ARTERY-50:23

IETT RANIUS- 50:24

LEFT GASTRIC ARTERY-50:17

b. Remainins vessels in relation to the walls of the omental bursa

GASTRODUODENAI ARTERI $-50: 25$

RICHT CASTROEPIPLOIC ARTERY-50:29

In exposing the following structures tiny remaining parts of the lesser omentumare removed, the right gastric artery, right gastroepiploic artery and stomach are divided just to the left of the pylorus, the stomach displaced toward the left side, and the posterior $\forall a l z$ of the lesser omental bursa carefully removed, but guarding against undue displacement of the pancreas.

SUPERIOR PAINCREATICODUODENAL ARTERY-50:26

COELIAC ARTEPY -50:16

LEFT GASTRIC ARTERY-50:17

HPPATIC ARTERY-50:19 For its branches see the preceding

SPLENIC ARTERY-50:31 section, $4 a$.

PANCREATIC RA:II-50:32

LWFT GASTROEPIPIOIC ARTERY-50:33

SHCRT GASTRIC ARTERIES-50:34

SPLENIC RAIII-50:35

PORTAL VEII-55:15

CORONARY VEIN OF THE STOMACH-55:16

SUPERIOR NESRNTERIC VEIN-55:17

INFERIOR IESENTERIC VEIN-55:26

SPLENIC VEIN-55:30

LEFT GASTROEPIPLOIC VEIN-55:32

CYSTIC VEIN-55:33 

PAREMRILICAL VETIS-55:36

The portal vein also participates in important oosophageal, rectal, peritoneal and umbilical anastomoses.

\section{Duodenum and pancreas}

2. Duodenum-33:45

PARS SUPERIOR-33: 46
PARS DESCENDENS-33:47
PARS HORIZONTALIS $-33: 49$
PARS ASCENDENS-33:50

PARS ASCENDENS-33:50

SUSPEINSORY HUSCLE OF THE DUODENUM-33:54

DUODENAL PAPILLA-33:56

Exposed by making a longitudinal incision through the anterior vall of the duodenum.

LONGITUDINAI FOLD OF DUODEIVUN-33:55

\section{b. Pancreas-34:26}

HEAD OF PANCREAS $-34: 27$

UNCINATE PROCESS-34:28

NOTCH OF THE PANCPEAS-34:20

BODY OF EANCREAS $-34: 30$

ANTERICR, POSTTEIOR AND INFCRIOR SURFACES-34:31-33

SUPERTOR; ANTERIOR AND POSTERIOR MARGINS-34:34-36

OAENTAL TUBER-34:37

TAIL OF PANCREAS-34:38

PANCREATIC DUCT-34:39

ACCESSORY PAICPEATIC DUCT-34:40

(ACCESSORY PANCREAS) $-34: 41$

\section{Stomach and spleen}

a. Stomach-32:78

VAGUS IWRVE-68:22 In its relation to the stomach and adjacent organs.

ANTERIOR AND POSTERIOR GASTRIC PLEXUSES-68:51, 52

HEPATIC RAMI-68:53

COELIAC RANT-68:54

STOIIACH $-32: 78$

AITERIOR AND POSTERIOR WALLS OF STOMACH-32:79, 80

GREATER AUD LESSER CURVATURES OF STOMACH-32:1, 2

CARDIA-33:3

FUNDUS OF \$TOAACH-38:4

BODY OF STOMACH- $33: 5$

PYLORUS-33:5

CARDIAC PART-33:7

PYLORIC PART-33:8

(CARDIAC A:NTRU:I) $-33: 9$

PYLORIC AITRUII-33:10

The exposure of the following structures is facilitated by dividing the abdominal part of the oesophagus, removing the stomach, and opening the stomach by an incision along its greater curvature. SEROUS CCAT-33:11

NUSCULAR COAT-33:12

LONGITUDINAL LAIER-33:13

CIRCULAR IAYER-33:15

OBLIQUE FIBERS-33:17

SPIINCTER IUSCLE OF PYLORUS-33:16 

PYLORIC VALVE- $-33: 18$

TELA SUBNUGOSA-33:19

TUNICA IUCOSA $=33: 20$

GASTRIC PITS $-33: 24$

b. Spleen-35:18

DIAPHRAGHATIC SURFAGE-35:19

REIHAL .TIRFACE-35:20

GASTRIC SURFACE-35:21

SUPERIOR AID INFERIOR EXTREMITIES-35:22, 23

POSTERIOR AND ANTERIOR MARGINS-35:34, 25

TUNICA SEROSA-35:27

TUNICA ALBUGINEA-35:28

SPLEIIC PULP-35:30

SPIENIC RAII OF SPLINIC ARTERY-35:31

(ACCESSORY SPIEEN) $-35: 34$

7. Sympathetic plexuses in relation to the coeliac ganglion and coeliac

COELIAC PLEYUS- $\frac{\text { pIeXUS }}{72 \cdot 19}$

COELIAC GANGLION-72:20

If the thorax has been previously dissected, these ganglia may be conveniently located by tracing the great splanchnic nerves down to their junction with the gangitia.

SUPERIOR GASTRIC PLEYUS-72:26

HEPATIC PLEXUS-72:24

INFERIOR GASTRIC PLEXUS-72:27

SPLENIC PLEXUS-72:25

RENAL PLEXUS-72:29

SUPR 1 RENAL PLEXUS $-72: 28$

PHREINIC PLEXUS-72:22

SUPTRIOR NIESENTERIC PLAXUS-72:32

ABDOIINAL AORTIC PLEXUS $-72: 18$

\section{Liver $-34: 43$}

For the ligaments and peritoneal relation of the liver, see IV:Ic The removal of the liver involves the following incisions: a) division of the portal vein at the level of the foramen epiploicum; b) raising the liver as much as possible, cutting through the inferior vena cava vein at the point where it comes in contact with the inferior aspect of the liver and to the right of the inferior vena cava cutting through the inferior layer of the coronary ligament: c) in connection with the superior and posterior aspects of the liver dividing the ligamentum teres and the falciform ligament, the right and leit triangular ligaments and superior layer of the coronary ligament; d) separating the posterior surface of the liver from the diaphragm and make a second cut through the inierior vena cava just below tine diaphragm and completing the detachment of the organ.

RIGHT LOBE OF LIVER-34:59

GUADRATE IOBE OT IIVER-34:60

CAUDATE LOBE OF IIVER-34:61

PAPIIIARY PROCESS- $24: 62$

CAUDATE PROCESS-34:63

LEFT IOBE OF LIVER-34:64

RIGHT SAGITTAL FOSSA-34:49 

FOSSA FOR THE GALI BIADDER. $34: 50$

FOSSA FOR VENA CATA $.3 \leq: 5]$.

LEFT SAGITRAT, FOSSA-34:52

FJUSA FOR UMEIIICAL VEIN= 34:33

FOC.SA FOR DUCTUS VENOSUS-34:54

ANTERIOR WISRIN $-34: 17$

INCISURA. UTETLTCALIS $-34: 48$

SUPERIOR SIREACT $=34: \$ 4$

POSTEPIUR STRFACE-34:45

OSSOPHA IEAL IMF RESSION-34:68

SUPRAEUNA IMPNESSION-34:73

INFERICR AURF:CE-34:45

POF.TA HEPATIS $=3 \frac{3}{2}: 58$

OLENCLI. TLERR- $54: 07$

GAETSTC IMPKTSDIDN-34:69

DUODENAT, INPPBSSIOH $-34: 70$

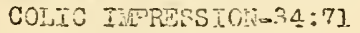

REIAL INPRESSTON-34:7\%

The following h3patic structures may be demonstrated in cut surfaces of the liver, soile of them requiring a hand lens or microscope for their identification.

HEPATIC LOBUI:S-34:74

FIBROUS CAPSUT. E-3 $3 \frac{1}{2}: 75$

INTERLOSUUAAR ARTERTTS $-34: 76$

INTERLCDUTLAR VETIS $-34: \% 7$

CENTRAI, VGINE.34:78

BILE DUCTS-95:I

INTTRLORJTAR DUOTS-35:2

VASA APERRATIA HEPATIS.-35:3

BILE-3:5:5

GALL BIATDER-25:6

FZRDCE OH GALT, BTADDER 35:7

BODY OF GATI BJADUER $-35: 8$

IECK OF CA:I, BIs DDER-35:8

CYSTIC DUCI-35:10

SPIPAL VALVE-35:15

The following structures require a hand lens or a microscopo

for their adequate demonstration:

TUNICA SEROSA OF GALL BLADDER-35:11

TUNICA MLSUULARIS GF GALL BLADDER $35: 12$

IUNICA IIUCOSA OF GALL BLADDER-35:13

PLICAE TUIICAE STUCOSAE OF GALL BLADDER-35:14

GLANDUIAE MUCOSAE BILIOEAF-35:17

\section{y. Suprarenal giand, isdney and ureter}

a. Supre:ena. I_Eland $30: 52$

HILUS OF SUPPAR INA GIAND-39:55

ANTERIOR AND POSTEPIOR SURFACES-39:56, 57

BASE $-39: 58$

$A P E X-39: 59$

SUPERIOR AND IDDIAL WARGINS-39:60, 61

(ACCESSORY SUPRARENAL GLANDS) $-39: 63$

CORTICAL SUBSTANCE-39:53

MEDULILARY SUBSTANCE $-39: 54$

CENTRAL VEIN-39:62 

b. Vascular supply of the kidney anc suprarenal glands

Exposed by removing the kidneys and suprarenal gland, 'before coing this however, advantage may be taken of the opportunity $0:$ determining the relations of the kidney to these organs and adjacent structures).

RENAL ARTERY-50:50 cf, also-39:4

INFERTOR SUPRARENAL ARTERY-50:51

IUIDDLE SUPRARENAL ARTERY $-50: 49$

RENAL VEINS-55:9

SUPRAREIAL VEINS-55:10

c. Kidney $-38: 37$

ADIPOSE CAPSULE-38:49

LATERAL MARGIN-38:38

NEDIAL MARGIN-38:39

PENAL HILUS-38:40

RENHI, SINLS-38:41

ANTERTOR AND POSTERIOR SURFACES-38:42, 43

SUPERIOR AIND IIFERIOR EXTREIITIES-38:44, 45

(HEPATTC IIPRESSTON) $-38: 46$

(GASTPIC TALSSSION) $-38: 47$

The following inay be demonstrated to best advantage by cutting

through the kidney along its lateral margin and dividing the organ into symmetrical halves:

TUNICA FIB?OSA-33:50

CORTICAL SUBSTANCE $-38: 55$

MEDULIARY SUBSTANCE-38:56

RENAL PYRAMIDS -38:58

RENAL PAPIILAF-38:60

RENAL COLUINS $-38: 63$

RENAL PELVIS-38:70

RENAL CALCYEES-38:71

d. Ureter-39:19

ABDONIINAL PART-39:20

\section{Diaphragm}

DIAPHRAGM-25:9

LUMBAR PART-25: 10

IEDIAI CRUS $-25: 11$

INTERIEDIATE CRUS-25:12

LATERAI CRUS-25:13

COSTAL PART-25:14

STERNAL PART-25:15

AORTIC OPEIIIVG-25:16

OESOPHACEAL OPENING-25:17

CENTRAL THNDON-25:18

OPENING FOR VENA CAVA-25:19

MEIAI LUUBOCOSTAL ARCI-25:20

LATERAL LUEBOCOSTAL ARCH-25:21

V. Structures in Relation to the Posterior Abdominal Wall

1. Blood-vessels and lymphatics 



\section{a. Arteries}

ABDONIIIAL AORTA $-50: 5$

PARIETAL BRANCHES $-50: 6$

INFERICR PHRENIC ARTERY-50:7

SUPERIOR SUPRARENAL RAMI-50:8

LURBAR ARTERIES-50:9-11

These arteries pass posterior to the sympathetic

trunk which together with utber nerves of the

abdominal wall should be guarded from injury.

MTDDLE SACRAL ARTERY-50:12 Origin only.

VISCERAL BRANCHES -50:15

For the rami of the first five of the following arteries

see IV:2, $4 \mathrm{~b}$ and $9 \mathrm{~b}$.

COELIAC ARTERY-50:16

SUPERIOR NESENTERIC ARTERY $50: 36$

I.JFERIOR IESENTERIC ARTERY-50:45

IIIDDLE SUPRARENAL ARTERY-50:49

RENAL ARTERIES -50:50

INTERNAI SPERMATIC ARTERIES-50:52

TESTICULAR ARTERY-50:53 In the male.

OVARIAN ARTSRY $-50: 54$ In the ferale.

COAMON ILIAC ARTERTES-50:55

HYPOGASTRIC ARTERY $-50: 56$ Origin only.

EXTERINAL ILIAC ARTERY -5i:31

INERRIOR EPICASTRIC ARTERY-5: $: 32$

DEEP CIACUAFLEX ILIAC ARTERY-51:37

b. Veins and I ymohatics

INFERIOR VENA CAVA-55:3

PARIETAL ROOTS $-55: 4$

INFERIOR PHRENIC VEIN-55:5

LUIBAR VEINS $-55: 6$

VISCERAI R.OOTS $-55: 7$

HEPATIC VEINS-55:8

REINAL VEINS $-55: 9$

SUPPARENAL VEINS-55:10

SPERIVATIC VEIIT-55:II

TESTICULAR VEIN-55:12

OVAIIAN VEIN-55:13

CONAON ILIAC VEINS-55:37

WIDDLE SACPAL VEIN-55:38

IVPOGASTRIC VEIN-55:39 Termination only.

EXTERNAL ILIAC VEINS-55:58

INFERIOR EPIGASTRIC VEINS-55:39

CISTERIHA CHYLI-56:28

DEEP CIRCUANLEX ILIAC VEIN-55:50

INTESTINAL LNPHATIC TRUNK-56:27

LUIEAR LT.PHATIC TRUNKS-56:26

ILIAC LYAPH GIANDS-56:57

LUMBAR LYMPH GLANDS-56:58

COPLIAC LYIPH GLANDS-56:59

AZYGOS VEIN-56:53

HEITAZYGOS VEIN-56:54

2. Fascia and muscles of posterior abdominal wa?l 

QUADRATUS LUMBORUM MUSCLE $-25: 32$

ILIOPSOAS MUSCLE- $-26: 63$

ILIAC MUSCIE-26:64

PSOAS MAJOR MUSCLE-26:65

In the demonstration of this muscle the following nerves are encountered and should be guarded from injury: the sy:mathet trunk, medial to it, the genitofemoral nerve in relation to its anterior surface, the ilicinevinal and lateral femoral cutaneous nerves in relation to its lateral margin, and the femoral nerve, situated between the psoas major and iliacus nuscles.

PSOAS IIINOR MUSCLE-26:66

3. Nerves of the posterior abdominal val. I

ABDONINAL PART OF THE SYAPATHEIIC TRUNK-72:15

LUMBAR GANGI,IDN= $72: 16$

RANI CONAIUNICANTES $-68: 72$

TWE IFTH INTERCCSTAL NERVE-70:1

LUMBI R NERVES -70:11

In demonstrating the Iumbar nerves and lumbar plexus the psoas major muscle is removed by blunt dissection.

LUMBAR PLFXUS - 70:23

MUSCULAR RAMI-70:24

ILIOHYPOGASTRIC VERV $-70: 25$

ILIOINGUINAI INERVE-7C..29

GENITOFEIVRAL NERVE $\approx 70: 33$

LUMPOTNCUINAL NERVE $=70: 34$

EXTERNAL SPERMATIC NERVE-70:35

LATERAL FEMORAL CUTANEOUS IARVE-70:36

FEMORAL NERVE $70: 4.1$

OBTURATOR IERVE $70: 37$

LUBBOSACRAL TEJINK-70:22 Origin only.

\section{PET,VIS}

\section{Osteology}

COXAL BONE- $75: 7$

OBTURATOR FORAIINN-15:8

ILIAC BONE $-15: 14$

ILIAC CPDST:-15:18

ILIAC FOSSA $=15: 31$

ISCHIAL BONE-15:32

SUPERIOR RAIUS OF THE ISCHIAL BOIV-15:34

INFPRIOR RANUS CF THE ISCHIAI EONE-15:35

PUBIC BOIE $=15: 40$

OBTURATOR SULCUS-15:46

IIRPEIOR AND SUPERICR RANI OF THE PUBIC BOM-15:49, 50

\section{SACRUI:-7:5}

PELVIC SUREAOE $-7: 7$

PROMONTORY $-7: 10$

ANTERIOR SACRAL FORANINA-7:15

APEX OF SACRAI BONE-7:24

COCCYX $-7: 25$

PELVIS $-15: 52$

SYNPHYSIS OF PUBIC BONE-15:53 

PUBIC ARCH $15: 54$

MAJOR PELVIS-15:56

MIITOR PEIVIS- 15:57

LIIEA TWRMTNALIS-15:58

SUPERIOR APERTURE OF THE PELVIS-15:62

INFERIOR APERTURE OF THE PELVIS-15:63

PEIVIC AXIS-15:64

CONJUGATE, TRANSVERST AND OBLIQUE DIANETERS-15:65-67

PEIVIC IICLINATION-15:68

2. Peritoneum and fascia in reiation to the pelvis

a. Peritoneal folds in the male pelvis

TRANSVERS VESICAL FOLD $44: 26$

PUBOVESICAL FOLD $44: 25$

MESORECTUM $\circ 43: 61$

b. Peritoneum of the female pelvis

RECTOUTERIIE FCTDS $>44: 35$

RECTOUTERINE EXCAVAIION $44: 36$

ESICOUTERINE EXCAVATION-44:37

FOSSA OVARICA $.44: 33$

BROAD LIGAIEIN OF UNERUS- $44: 29$

ISSO:RTRIU:-44:30

MSOSI,PINN. $44: 31$

NESOV:RIUS $-44: 32$

STEPENSORY LIGAIENT OF THE OVARY $-44: 34$

\section{c. Fascia}

PELVIC FASCIA $-43: 26$

Demonstrated by removing the pelvic peritoneurn by blunt dissection, guarding at the same tine against injury to nerves and vessels.

SUPERIOR FASCIA OF PELVIC DIAPHRAGM-43:28

TENDINOUS ARCH OF PELVIC FASCIA-43:29

ENDOPELVIC FASCIA-43:27

NIDDIE PUBOPROSTATIC LIGANENT-43:30 In the male. MIDDLE PUBOVESICAL LIGANENT-43:30 In the female. IATERAL PUBOPROSTATIC IIGAIENT-43:31 In the male. LATERAL PUBCVESICAL LIGAIETT-43:31 In the iemale. The demonstration of the anterior relations of the pelvic fascia is completed and the subsequent exposure of pelvic viscera facilitated by making the folloving dissections: a) detaching the suspensory ligament of the penis from the iront of the symphysis, guarding at the same time against injury to the dorsal vein of the penis; b) detaching all muscles and fascia from the anterior surface of each pubic bone over a region extending about $2.5 \mathrm{~cm}$. laterally from the sympinysis pubis; c) sawing through the pubic bones by an incision on each side of the symphysis pubis exiending from the pubic tubercle to a point just below the attachment of tre arcuate ligament of the pubis; and d) detaching the pelvic fascia from the posterior surface of this isolated segment of bone and carefully removing the bone (retaining the latter for later reference).

INEERIOR FASCIA OF THE PELVIC DIAPHRAGI-43:32 

SUPERIOR EASCIA OF THE UROGENITAL DIAPHRAGN-43:36

\section{Pelvic viscera}

a. In the male polvis

URINARY BLADDER-39:29

VERTEX OF BLAD́DER-39:30

BODY OF BLADDER-39:31

FUNDLS OF BLADDER-39:32

URACHUS ${ }^{x}-39: 34$

The following structures are exposed by an incision beginning at

the vertex of the bladder and extending through its wall in an anterior-poseterior direction in the line of its median plane. TUNICA SEROSA-39:35

TUNICA MUSCULARIS-39:36-39

TELA SUBMUCOSA-39:42

TUNICA MUCOSA-39:43

TRICONE OF THE BLADDER $-39: 46$

UVULA OF THE BLADDER-33:47

URETERAL FOLD-39:48

ORIFICE OF URETER-39:49

INTERHAL URETHRAL ORIEICE $\rightarrow 39: 50$

URETHRAL RING-39:51

MALE URETHRA- $-1: 19$

Its internal structure is exposed by introducing a blunt pointed scissors into the internal urethral orifice and dividing the dorsal wall of the urethral canal throughout its entire extent. PROSTATIC PART-41:20

URETHRAL CREST-41:21

SEIVINAL HILLOCK $41: 22$

PROSTATIC UTRICIE- $41: 23$

EJACULATORY DUCTS $-40: 30$

PROSTATIC DUCTS- 40:59 Their openings only.

MEMBRANOUS PART $41: 24$

CAVERINOUS PART-41:25

EXCRETORY DUCTS OF BULBOURETHRAL GLANDS $-40: 64$

NAVICUEAR FOSSA OF URETHRA-41:26

(VALVULA FOSSAE NA.VICULARIS) $-41: 27$

PENIS-40:66

EXTERIAL URETHRAL ORIFICE-41:2E

UR:THRAL I.ACUNAE-4I:29

The following structubes are demonstrated in cross sections of the penis. For other structures of penis see II:Ib and $2 a$. CORPUS CAVERNOSU: PENIS-4I:4

CORPUS CA VERIYOSUI URETHRAE-41:5

TUNICA ALBUGINEA $-41: 5$

SEPTUM PENIS- $-1: 10$

TRABECULAF CORFORUI CAVRRIVOSORU: $-41: 11$

CAVERNAE CORPORULI CAVERNOSORUL-4I:12

The demonstration of the remaining pelvic structures nay be

facilitated by detaching the fifth lumbar vertebrae from the sacrum, dividing the sacrura, coccyx, and any remaining soft structures in the median sagittal plane, and separating the tro halves of the pelvis. RECTL:I-34:9

SACRAL FLEXURE-34:10

PERINEAL FLEXURE-34:11

RECTAL ANPULLA $-34: 12$

MUCOUS MEMBRAIN-34:17 

TRANSVERSI RECTAL FOLDS-34:21

RECTOCOCCYGEAL NUSCIE-34:I5

AIAL PART OF DECTLI $34: 22$

PECTAL COLUINS-34:23

RECTAL SINUSES $=34: 24$

HUINORRHJIDAL, RII!G-34:25

SPHINCTER AND INTERNUS MUSCLE-34:14

PELVIC PAPT OF URETER-39:21

PROSTATE $-40: 50$

BîSE $-40: 51$

AFPX-40:52

ANTPEIOK AID POSTERIOR SUREACES-40:53, 54

RIGIIT AND LEFT LOBES-40:55

ISTHITUS-40:56

(MIDDTE LOBE) -40:57

SEMINAL VESICLES-40:32

BCDY OF SFIIINAL VESCE

EXCRETORY DUCT-40:36

DUCTUS TPEERENS- $-0: 21$

AMPUILA OF DUCPUS DR,ECPENS $40: 22$

DIVERTICFIA OF AIRULIA $=40: 23$

PISACULATORY DUCT $-40: 30$

b. In the ferale nelyis

The demonstration of the following structures nay be facilitated by detaching the fifth lumbar vertebrae from the sacrum, dividing the sacrum, coccyx, sympiysis piois and any remaining soft structures, in the median segittal plane and separating the two halves of the pelvis.

PERITOIEUT:-43:40

For structures relative to the peritoneum in the female pelvis, see rJ:2b.

PELVIC FASCIA-43:26 cf. VI:20.

URIN ARY BLADDER-39:29

For structures relative to the urinary bladder, see VI:3a. FEHAL' URETHRA-42:70

EXENEI. URETHPAL ORITICE-42:71

CRISTA URITHAIIS $-43: 2$

PEIVIC PRPT CF TRDLEN-39:21

$\because A F I-42: 30$

IILUS $-41: 37$

IEDIAI AIV LATPRAL SURFACES-41:38, 39

FREP MARGTN-A1: $=0$

SESOVARIAN MARGIN-4I:SI

TUBAL JYTHEIITY $-41: 42$

UTERIIE EXTREITY- $11: 43$

OVARIAN LIGANENI $-41: 50$

CORPUS LUIEU: $-41: 51$

CORPLS ALBICAIIS- $41: 55$

PAROOPHORON $-42: 43$

EPOOPIIORON- $42: 39$

UTPRTIE TUBH-4]:57

OSTIUM ABDONINALF-41:58

INEUIDIBULU:I-41:59

FI:PBRIAT-41:60

FINBEIA OVARICA-4I:61

AIPULIAA $-41: 62$ 

ISTHIUS $-41: 63$

UTERUS $-41: 76$

BOLY OF UTERUS $41: 77$

FUNDUS $-42: 1$

LATERAL THRGIN-42:2

VESTCAL SURFACE-43:3

INTESTINAL SURFACE $-42: 4$

UTERINE CAVITY-42:5

CERVIX-42:7

CURRAVAGI TAE PART-42:8

VAGINAL PART-42:9

EXTERNAL ORIFICE OF UTERUS-42:10

ANTERIOR LTP $=42: 11$

POSTERIOR IIP $-42: 12$

CANAL OF THE CERVIX-42:13

INIERNAL ORIFICE OF THE UTERUS-42:6

LICANENTUN TERES-42:23

VAGIIIA-42:25

FORIIX OF VAGINA- $42: 26$

ANTERIOR AIND POSTERIOR NALIS-42:27, 28

HYIIE: $42: 29$

HYTIEAL CARUNCIES-42:30

RECTUN-34:9

For its structural characteristics, see VI:3a.

\section{PeIvic blooa vesseis (male and femele)}

In the following tabuiation vessels which are either male or female only are so indicated. All other vessels are common to both sexes.

a. Arteries

HYPOGASTRIC ARTERY $=50: 56$

PARIPTAI RANI OF THE HYPOGASTRIC ARTERY-50:57

ILIOLUNBAR ARTERY.-50:58

ILTMBAR RAMISXX $-50: 59$

SPINAL RAIIUSCX $-50: 60$

ILIAC RAMUSXX $-50: 61$

LATERAL SACRAL ARTERY-50:62

SPINAL RAIII $X_{-50}: 63$

¿BTURATJR ARTERI-50:64

PUBIC RAMUS - 50:65

SUPERIOR GLUTEAL ARTERY-51:1

INEERIOR EHUTEAL ARTERY-5I:4

VISCERAT, RAII OF THE HYPOGASTRIC ARTERY-51:6

UEREILICAL ARTERY-51:7

SUPERIOR VESTCAL ARTERTSSXX-51:8

KLATERAL UEILICAL IICAIINT

INFERIOR VESICAL ARIERY-51:10

DEFTRENTIAE ARTERYX $\times-51: 11$

UTERINE ARTERY-51:12 In the female only.

VAGINAL ARTERY-51:13

OVARIAN RAMUS-5I:I4

TUBAL RAIIUS-51:15

OVARIAN ARIERY-50:54 In the female only.

HIDDEE HEIORRHOIDAL ARTERY-51:16

INTERNAL PUDENDAL ARTERY $-51: 17$

For its perineal rami in both male and female see

II:2-4. 

SUPERIOR HE UZTHOIDAL ARTERY-50: 48

WIDDLE SACRAL ARTERY-50:12

LOWEST LUURAR ARTERYX: $-50: 13$

GLOAUS COCCYGEUA $X \times-50: 14$

b. Veins of tine pelvis

HYPOGASTRIC VEIN-55:39

The tributaries of the hypogastric vein-55:40,49:53,55-57,

correspond to a large degree mith the branches of the hypogastric artery.

HEIORRHOIDAI PLTXUS-55:46

VESICAL PLZXUS $X \times-55: 47$

PUDEINDAL PIPXUQX $-55: 48$

UTEROVAGINAL PIEXUS XX 55:54 In the femaie onIy.

MIDDLE SACRAL VEIN $2 X-55: 38$

5. Pelvic muscles and nerves

Exposed by displacing the viscera from the lateral pelvic walls and removing any remains of the superior fascia of the pelvic diaphrar $43: 28$, guarding at the same time against injury to the fifth sacral and coccygeal nerves.

PELVIC DIAPIRAGM $43: 20$

LEIATOR ANI NUSCLE- $3: 21$

TENDINOUS ARCH OF THE LEVATOR ANI MŨSCLA-43:22

COCCYGEUS NUUSCLE-43:23, 25:59

SACRAL PLEXUS-70:47

LUMBOSACRAL TRUTK-70:48

SUPURIOR GLUTEAI NERVE-70:49

INFERIOR GLUTEAL IREVE-70:50

POSTERTOR FITORAL CUTAIEOUS IERVE-70:51

SCIATIC IAR:F-70:54

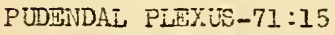

HIDDL HE: ORPHOTDAL NERVS ${ }^{x x}-71: 16$

INEERIOR VEICAL TERVES ${ }^{x x}-71: 17$

VAGINAL INRVSXY-71:18 In the ferrale.

PLDPDDI IE?

COCCYGEA: $: U R V E X X-7 I: 26$

PELVIC PART OF HE SYPATHEIIC SISTEN-72:15

SACPAL GAGIIA-72:17

ODTURATOR FASCIA- $-3: 40$

OBTURATOR INITRNUS IUUSCIE-26:72

PISIFORIIS NUSCLE-23:71

6. Pelvic articulations

LIGAIENIS OF THE PELVIC GIFDLE-20:45

OBTURATOR IEIBRANE-20:46

OBTURATOR CANAL-20:47

ILIOLUABAR LIGAASTIT-20:48

SACROTUBPROUS LICAINTID-20:49

FAICIFORI PROCESS-20:50

SACROSPTHOLS IICAIMNI-20:51

GREATER SCIATIC FOPAITI-20:52

LESSER SCIATIC FORAIEN-20:53 

SACRO-ILIAC ARTICULATION-20:5\%

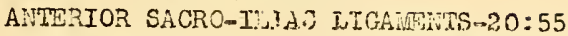

IIVEROSSEOUS SACRO-ITIAC LIGATENS - 20:56

LONG AND SHORT POSTERIOR SACRO-ILIAC LIGAMENTS-20:57, 58. SVNOVIAL CAVITY

SYMPHYSIS PUBIS-20:59

SUPERIOR PUBIC LIGAIENTS-20:60

ARCUATE IIGANENT OF PUBIS-20:61

IIITENTEIC FIBRO-CARTIIACD-20:62

Demonstrated by removing a slice of bone from the front of the symphysis pubis.

SACRO-CCCCYGEAL SYMPHYSIS- I8:48

SUPPDFI.IAL POSTERIOR SACRO-COCCYGEAL LIGAMENT-18:49

DEEP FOSTERTOR SACRO-COCCŸGEAL LIGANENT-I8:50

ATTERIOR SACRO-JOCCYGEAL IIGÄIENT-18:51

LATERAL SACRO-COCCYGEAL LIGAIENT-18:52 

INFERIOR EXTRENITY

$\ldots+\ldots$ 



\section{General charcteristics of the infericr extremity}

1. Subdivisions

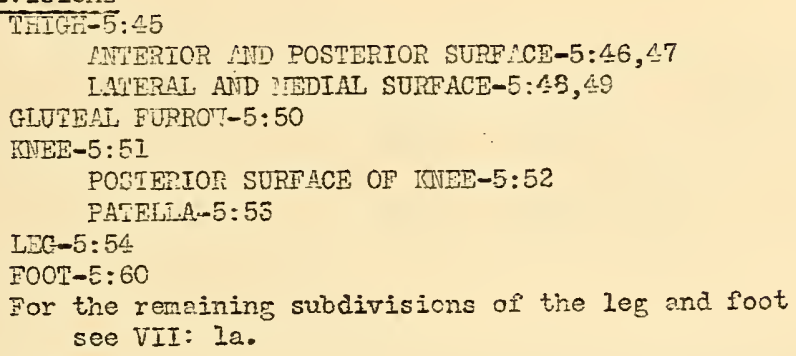

2. Regions

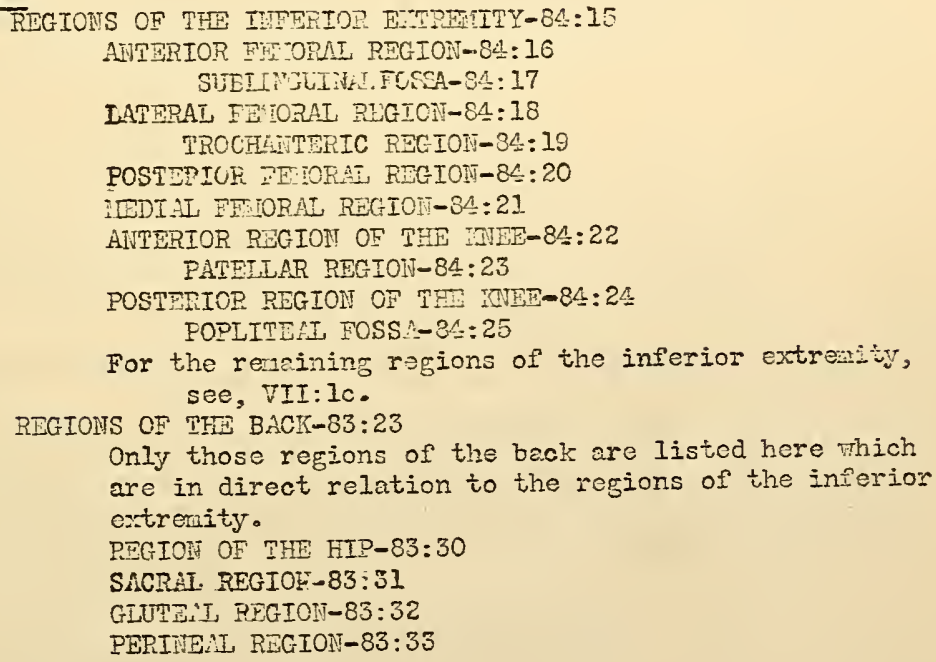

II. Glutcal region

1. Surface Anatomy

IITES-5:5

ANAL CLEET $-5: 7$

COCCYX $-7: 25$

S:CRTII-7:5 

CREST OF THE ILIUL:-25:18

CAITPERIOR SUPERIOR ILIAS SPIHE-15:22

POSTERIOR SUPERIOR ILIAC SPINTE-15:24

GLUTEAL SULCUS $-5: 50$

TUBEROSITY OF ISCHIUI-15:36

GREATER TROCHINTTR-16:2

\section{2: Fascia and cutanecus nerves}

Sirin incisions: a) from the posterior superior iliac spine along the iliac crest as far forward as possible; b) from the posterior extromity of (a) obliquely distally and medially to the middle line of the sacral region, thence distally to the tip of the coccyx; c) from the tip of the coccyx distally and laterally, crossing the middle point of the gluteal sulcus, to the junction of the middle and proxinal thirds of the thigh.

SUPEPFICIAI FASCI:1-23:36

SUPERIOR CIUNIAI INERES-70:15

IIIDDLE CLUNI II, NTPVES-70:21

LATERAI CUI WIEOUS RAUS OF THE ITIOHYPOGASTRIC NERVE-70:27

LATERAI CUTINEOUS R:IUS OF THE TTELFTH THORACIC NERVE-69:76

ITHERIOP CLUNIII TIERVES-70:52

PERIITE:I R I OF THE POSTERIOR FENOR I CUT ANEOUS NERVE- 70:53

DEEP FASCI-25:32

3. Glutzeus maximus muscle

GLÜLADS TAYIUS IUSCIT-26:67

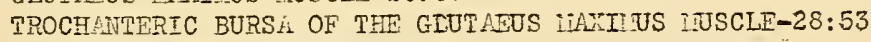

GLUTAEOFE:TORII BURS E-29:5

SCIATIC BUPSA OF THE GLUTAEUS IIAXILUS IUUSCIE- $2 x_{29: 6}$

4. Structures exposed by the reilection of the Elutaetus maximus muscle

Demonstrated by separating the gluteeus maximus muscle from the underlying structures, detaching it at its origin and reflecting it toward its insertion; at the same time exposing and cutting its nerve and vascular supply, but leaving intact the posterior femoral cutaneous nerve, sacrotuberous liganent and perineal region.

a. Structures distal to the piriformis muscle

IIFERIOR GIOTREI NERE-70:50

INFERIOR GLUTEAI ARTIRY-51:4"

POSTERIOR FEIORAI CUTAITOUS NERTE-70:51

SCIATIC NERVE-70:54

TNTERNAL PUDENDAL ARTERY-51:17

FUDEID.IL NERVE-71:19

HERVE TO THE OBIURATOR INTERNUS IUSCLE

PIRIFORIIS IUSCIE-26:71

OBTURATOR INTERIUS IUSCIE-26:72

SUPERIOR AND INFERIOR GEIEILI IUSCLES-26:73, 74

CUADRATUS FEIORIS IUSCLE-26:75 

INERVE TO THE QUADEATUE FEIORIS IIUSCTS

Exposed by detaching the two gemelli muscles at their origins, cutting the tendon of the obturator internus at its exit from the lesser scictec foramen and reflecting these structures to-rard their insertions. The folloming structures are demonstrated by detaching the quadratus fenoris muscle at its origin and reflecting it toward its insertion. OBRUPATOR EXTERIUS IUSCLE-27:10

ITDIAL FI OR CI CIRCUIFIEX ARTERY-5I:46 Terminal branches only

b. Structures proximel and lateral to the piriformis nuscle

GIUT:EUS ZTDIUS :USCL-20:68

HERVE TO THT TINSOR FASCIAE IATAE IUUSCLT

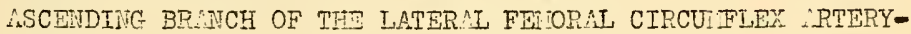
$51: 51$

The folloving structures are exposed by sepurating the glutacus medius muscle from the gluteeus minimus muscle, dividing the glutacus nedius muscle about $5 \mathrm{~cm}$. proximi to the greater trochnter and replecting the tro parts torard their origin and insertion, respectively. SUPEPTOR GLUTEIL :RTPRY-5I: 1 SUPTPIOR GIUTPAI NISPVE-70:49 GIUTAEUS INI UII IUSCLE-26:69

5. Structures exposed by the reflection of the gluteeus mininus muscle.

Denonstrated by detechine the gluteeus rinimus ancle at its oriein nd reflectins - $\because$ tora its insertion.

ARTICULAR CAPSULE OF HID-20:64

TROCHAJTERIC BURSA OP GLUTAEUS IINIIUS IUSCIE-29:2

REFLECTED TENDOIN OF THE RECTUS FEIORIS IUSCLE

\section{Popliteal Space}

I. Surface anatony

TIIDON OT THE BICEPS FITORIS IUSCLE-27:11

TENDONS OF THE SEIITENDINOSUS AND SEIITI BR:INOSUS

IUUSCLES $-27: 14,15$

TINDON OF ADDUCTOR :-ANTS ITSCIE-27:8

BPICONDYLES OT FIU - $.9 \cdot 20$

II:A OP TEUT:-16:5:=

COITION PERONEAT NERVE-70:56

\section{Fascia, superficial nerves and vessels}

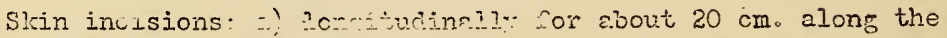
midole line of the posterior region of the lnee, extending about $10 \mathrm{~cm}$. distel and promingl to the line oi the crticulstien o. ine inse; b) transversely at acel end of the preceding incision. 

SUPEFFICIAI FASCIA-23:36

POSTERIOR FEIOPAI CUTANEOUS NERVE-70:51 Termine1 branches ciny.

SUALI, S PHENOUS VEIT $56: 1$

FEFIOROPOPLITEAT, VEIN-56:2

DEEP FASCIA-27:70

\section{Popliteal space; large nerves and vessels}

Exposed by making a longitudinel incision through the deep fascia in the middle line of the popliteal space, reflecting the fascia and demonstrating the structures rith a inininus of disscction.

TIBI 2 ITEPTE-70:68

COEETON PERONEAL NEPVE-70:56

POSTEPIOR FEIOR.AI SUT NEOUS NEPVI-70:51

POPIITRA ARTEPY-51:63

POPIITE I TEINS $-56: 4$

4. Popliteal space:medial and lateral bounderies

BICEPS IUSCID-27:II

SFITENDINOSUS IUSCLE-27:14

SEII IDIBRANOSUS IUSCLE-27:15

IATERA, HE:D OF GASTOONDEIIUE TUSCLE-27:24

DIDIAI IIED OF GESTROCNDIIUS IUSCID-27:25

PIANYTARIS IUSCIE-27:29

5. Contenis of the popiiteal space

2.Merves

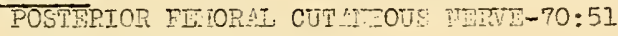

TIBIAE IIERTE-70:68

MUSCUL,AR PAIT-70:69

IFDIAT SUPAI CUTANBOUS MEPVE-71:2

INPOSSEOUS CPUPAI NDPVE-71:1

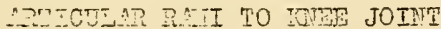

COIEIT TIRONEAI NERTE-70:56

IXTRRAT, SURAI CUT-NTOUS NERTI-70:58

PEOISAT AN STOEORT RATUS-7C:59

APIICULAR RAII TO TMEE JOINT

A genicular ramus of the obtruator nerve may be present.

b. Blood vessels ono Irmphatics

POPLITE:I SRTPRY-51:63

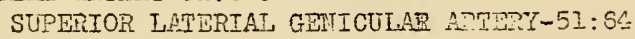

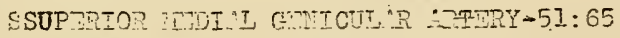

IIIDDLE GWICULAR ARTERY-51:66

INEBRIOR IATPR:I GUICUIAR ARTERY-5I:68

SURAT ARTERTES $-52: 67$

POPLITEN VEINS-56:6

POPLITEAI LYIPH GLNDS-57:5

5. Floor of the jopliteal spece

POPIITEAL SURFACE OR FEMUR-16:15

OBLIQUE POPLITE^I IIG NEITT-21:15

Associatcd trith it is the fascie of popliteus rusci.s. 

IV. Posterior Part of the Thigh

1. Fascia and cutaneous nerves

Skin incision:longitudinally through the skin remaining on the back of the thigh.

SUPEPFICIAI, FISCIA-23:36

POSTERIOR FEIOR.II CUTAINEOUS NERVE-70:51 Terminal razi。

NNTERIOR FEIORAL CUTANEOUS NEPVE-70:42 ITedial teminal rani only.

CUTAIFEOUS RAUS OF THE OBTURATOR NERVE-70:39

DEEP FASCIh-27:49

\section{Muscles}

BICEPS FEIORIS IUSCLE-27:11

IONG HIFAD-27:12

SHORT HE: D-27:13

SEITIETRRLNOSUS ITSCLE-27:15

BUPSA OF SEITEIBR 'INOSUS TUSCLE-29:26

3. Nerves and blood ressels

POSTEROTR FEMORAT, CUTANEOUS TERVE-70:51

ISCHINDIC NERTE $=70: 54$

IITSCULAP RAIT-70:55

FIRST PERFORAIING ARTERY-51:53

SECOND PERFOR:ITIU APTERY-51:55

THIRD PERTORATING ARTTRY $-51: 56$

PERTORITING VETNS-55:73

FEPOROPOPIITEAI VEIN-56:2

V. Anterior Part of the Thigh

1. Surface anatorny

ATITERIOR SUPERIOR IEIAC SPINE-15:22

SYPPFYSIS PUBIS-20:59

INGUTNAL LIGINENT-25:41

PUBLIC TUBERCII-15:44

PUBEIC ARCH-15:5^

INTERIOR RIIUS OF THE PUBIS-15: 19

INFERIOR RAIUS OF THE ISCHIUI-15:35

TUBEROSITY OD THE ISCHIUI-15:36

GREATER TROCHANTER OF THL FEMUR-16:2

PATEIIA-16:59

UEDIAL CONDYLE OF THE FEIUR-16:16

IATERL CONDYLE OF TFE FEIUR-16:17 

2. Regions in relation to the anteriot aspect of the thigh

AITIRIOR FETOR:I FEGION-3': 16

SUEIICUIMII FOSS:-84: $: 17$

IUTERAI FE OR'I PEGTON-84: 18

TROCHIIPERIC PEGION-84:19

IEDII FFIORAL PBGIOIT-OA:2I

3. Fascia, superficial ressels, Iyphatics and cutancous nerves

a. Suporfireśal fascia, blood vessels, and lyuphaijes cutcncous 12 Stin incisione: a) sro the enterior superior iliac spine along the line of the inguinal. Iiganent to the symphysis pubis: b) fron the median end of (a) distally, just lateral to the scrotur and along the wedial espect of the thigh for a. distence of $10 \mathrm{crin}$; c) fron the distal end of (b) cnteriorly anc tronsversely to the lateral aspect of the thigh: d) from the ond of incision (b) dista.1iy to the medial conayle of tho tibin; c) fron the latter point anteriorly and transversely to tho lotoral condyle of the tibia.

SUPEPFICTUT FISCI:-23:36

GREAI SAEHTHOUS TEINT-55:66

SUPEPFICINI TPIGASTRIC TETI-55:65

SUPEPFICINE CIRCUTFLE IIIAC VEIIT-55:68

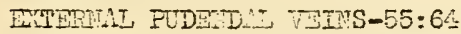

SUPEDICINE ERIGISTPIC $A$ RTERT-51:39

- SUPEETICIE CIPCUTTIR IIINC ARMBRT-51:20

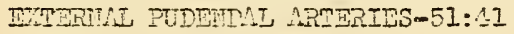

SUPERFICII SUEIUCUIINI IXPE GIMNDS-57:3

b. Fossa ovelis

FOSS: OTAIS-27:65

FACIFORI IJAPGTI-27:66

SUPEREOR COPIU-27:67

IIIPRTOR CORIN-27:68

FNSCIS CRIBOS1-27:699

Some of the deep subinguinal lymph glands-57:4, may be in relation to the fossa ovalis.

c. Cutareous nerves, superficial praepatellar bursae

IJIOINGUILII IERT-70:29

LUDBOINGUIIIS NERVE-70:3A

INTYRAI FE TORAL CUTINEOUS NERVE-70:36

MHTERTOR FE IORII CUTANEOUS ITEPVES-70:4-2

INFRIPATEIINR RNTUS OF THE SAIPFETIOUS IJEFUT-70:45

CUTAIEOUS PAII OF TIE OBTURATOR NEBVE-70:39

BUPSA PRIEPATCITUIPIS SUPCURANE1-29:12

BURSA PRATPITEITUISS SUPF:SCINTIS-20:I5 

d. Deep iescia

FASCIN INT-27:49

ILIOTIBIN TRICT-27:50

EMTTR:I IITERIUSCULAR SEETUI-27:51

IISDIAL INTERIUSCULAR SEPTUI-27:52

4. Fenoral sheath

Demonstrated by making an incision through the fascia lata beginning at the suporior cornu of the falcifors margin of the fossa ovalis and extending laterally to rithin about $2 \mathrm{cn}$. Of the antorior superior iliac spine, reflceting the fascial flap latcrally and rcmoving the subjacent fat and doop subinguinal lymph glands; contents exposed by a longitudinal incision through the anterior wall of cach of the three subdivisions or comportients of the shecth.

FE:ORN NRTERT-5I:38

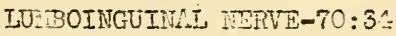

FETORAI VEII-55:6I

FEIORNI CANAI-27:62

The follo:ting structurss are pelpable by introducing the littlo firgor into the fenorel caral. FETOPNI RIIT-27:63 FTiOMII SEPIU:-27:64

IACUNAR IIGAIENT-25: 42

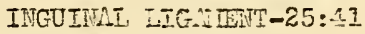

FEIORII TEIN-55:6I

DUBIC BOIE- $-15: 40$

FEMORIT FEIIII

5. FFomoral trigone and its contents

Exposed by renoving the fascie late from the anterior aspoct of the proximal third of the thigh.

FEEORAL TRIGOI:E-27:59

FASCIA ILIOPECTIIE $1-27: 56$

InCUNA TUSCULORU: $-27: 57$

IACTMI VASOPU::-27:58

FEIIORAI, NRTERY-51:38

SUPFPFICIN EPIG.STRIC ARTERY-51:39

SUPEFFICIAI CIRCUIFTEX IITAC ARTERY-51: 10

EXTERNAI PUDETDAI APTERIES-5I:L?

INGUINAI RIII XN-51: 4 -

DETP FTIORII ARTERT-51: 15

IEDIAI CIRCU IFITH EETORII ARTERY-51:46

FETIORI VEI I $-55: 6 I$

LIIERAI CIRCUIFI WIY FEIORAI CRTERY-51:50

SUPERFICIAI BPIGASTRIC VEIN-55:65

SUPERFICIAJ CIRCUIFIEX IIIAC VEIT-55:68

FYTTENAI PUDENDAI TETNS-55:68

GPE.T S.PHEIJOUS VBIT-55:56

ICCESSOPY S:PHENOUS VITN-55:67 

DLEP VEIORAJ VEINS-55:72

IEDIN CIRCÜTELEX FE TRII VEINS-55:69

LWITERI CIRCUIFUE FEIOR'I VEINS-55:70

LUEDBINGUIJIL NWIVE-70:34

IUTERIL FIIOR:L CUT:INEOUS INERVE-70:36

TESIORAL NTRVE-70:41

The folloring muscles are in relation to the floor and medial and lateral boundaries. of the trigone:

ADDUCTOR IONGUS IUSCLE-27:5

PECTINEUS ITUSCLE-27:4

ITIOPSO:SS IUSCLE-26:63

SIRTORIUS IUSCLE-26:76

POSSA ILIOFECTINEA:27:60

6. Aductor canal and its contents

$\therefore D D U C T O R$ C.THET-27:53

Exposed by malring a longitudinal incision through the fascia lota renaining on the distal two-thirds of the anterior aspect of the thigh and reflecting the fascial flaps laterally and medially, but leaving intact the iliotibial tract; contents denonstrated by a longitudinal incision through the fibrous anterior well of the canal.

FEIOR:L ARIBRY $-51: 38$

ARTEPIA GENU SUPREII-51:59

S:PIEEIOUS RNIUS $-51: 61$

IIUSCUIMR RAII-51:60

IPTICUILR R'TI-51:62

FEIOR:I, VEII-55:61]

SAPHENOUS TIRVE-70:44

TEIDIIOUS [ADDUCTOR] OPENING-27:54

7. Iuscles of the front of the thigh

S:RTORIUS UUSCIE-26:76

TEUSO? FISCI:I IA: IUSCIE-26:70

IIIOTIBI:I. TR:CT-27:50

IUTRR:I INTEPIUSCULAR SEPTUI OF THE THIGH-27:51

ITDIU INTEPIISCUIAR SEPTUI OF THE THIGH-27:52

QU.DRICEPS FE:IOPIS IIUSCLE-26:77

RECTUS FUIORIS IIUSCIB-26:78

BURSA OF RECTUS FEIOPIS IUSCIE $-29: 7$

VASTUS I:TERLIIS LUSCLE-26:79

VASTUS IEDIIIIS IIUSCIE-27:2

V:STUS IITTPITDIUS IUUSCLE-27:1

Exposed by making a transverse incision through the middle of the rectus fenoris muscle and reflecting the distal end. 

ARTICULARIS GENU IUSCLE- $27: 3$

Esposed by making a longitudinal incision through

the vastus s intermedius muscie.

COMRON TEINON OF THE OUDDICHPS FEMORIS MUSCIE-26:37

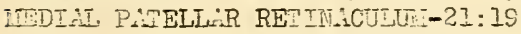

IATER I PATELIAT PUTIHACUIJI-21:20

\section{UI. Fiedial Side of the Thigh}

1. Lúsice, nerves and vessels

IDDUCROA IOHCUS IUSCLP-27:5

DLSP FE:OP:I, PMPRT-51:4:5

Lzposed by dotrohing tho-pootincus ruscle at its origin nd roplecteng it torard its insertion, gucrding, ct the sase time, the anterior ramus of the obturator nartc. PISST PERFORATIIG PRTSY-51:53

SUPTRIOR NUTRIEIT PEIOR: I

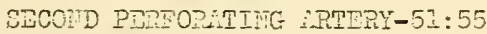

PHIPD PEPEOR:TIIG

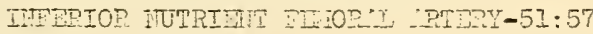

PECTIIEUS ITUSCIJ-27:4

PECTITEAT FASCI:-27:61

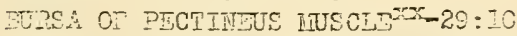

ITDIII CIPCUTIEX FEIORII IRTEPY-51:16

Bxposed by detaching the pectineus muscle at its origin and reflecting it toward its insertion. SUPEFFICIAI RAIUS $-51: 47$

DESP RA:UUS-51:48

ACETABULAF RATUS-51:49

ADDUCTOK BREVIS MUSCIE-27:7

CPTURATOR TFPVE-70:37

POSTERIOR RA:TUS-70:40

Exposed by detaching the adductor brevis musole at

its origin and reflecting it toware its insertion.

ANTPRIOR RAIIUS $-70: 38$

CUTANEOUS RAYIUS $-70: 39$

GRACILIS FIUSCLE-27:6

PROFEP BITSA OF SARTORIUS MUSCIE-29:19

BURSA ANSER ITA-29:20

ADDUCTOR WIIIIUS T TSCLE-27:9

ADDUCTOR TIAGNUS UUSCIE-27:8

TEMDI OUS [ADDJCTOP] OPEIIIT-27:54

The following structures are demonstrated by cetaching the adductor minimus and nagius muscles at their origins and reflecting them torard their insertions.

OBTUPAIOP FVTERIYUS IUSC:E-27:10

PSOAS TAAOR ITLSCID-26:65

ILIAC MTECOLE-26: 64 

OBTURATOR ARTERY-50:64

Demonstrated by the removal of the cbturator externus muscie bit by bit. ANTERIOR RAMUS-50:66

POSTERIOR PAMUS-50:57

APTERY OF IHE ACETABULUE- $50: 63$

\section{Hip Joint}

1. Structures in relation to the hip joint

Demonstrated by severing the femoral artery, vein and nerve, detaching the iliopsons muscle at its insertion, dividing the sarto:ius muscle near its origin and refiecting thesa structures together with the tensor fasciae latae muscle and exposing the capsule of the hip joint.

ILIOPECT INEAL BURSA-29:8

BURSA OF RECTUS FEIIOPIS MUSCLEXX-29:7

SUBTENDINOUS ILIAC BURSA-29:9

ARTICULAR CAPSULE=20:64

ILIOFEMORAL LIGAIENT-20:69

ISCHIOCAPSULAF. LIGA.TENT-21:1

PUBOCAPSULAP IIGNUENT - 21:2

ZONA OREICULARIS.-20:68

GLEIOID LIP-20:65

TRAISVERSE LIGAIENT OF ACETABULUR-20:66

LIGAMENTUM TEPES FEIIORIS-20:67

SYNOVIAL IREMBPANE-18:32

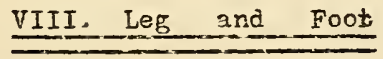

1. General Characteristics

a. Subdivisions of leg and foot

LEG-5:54

ANTERIOR AND POSTERIOR SURFACES $-5: 55,56$

CALF $-5: 57$

MIEDIAL AND LATERAL MALLEOLI-5:58,59

FOOT-5:60

TARSUS $-5: 61$

METATARSUS-5:62

DORSUM AND SOLE OF FOOT $-5: 63,64$

1.EDIAL AND LATERAL MARGINS $-5: 65,66$

HEEL-5: 67

DIGITS OF FOOT $-5: 68$

HALLUX $-5: 69$

DIGITS II-IV $-5: 70$

SI:ALLEST DIGIT $-5: 71$

DORSAL AND PLANTAR SURFACES-5:72,73

IEDIAL AND LATERAL MARGINS $-5: 74,75$ 

b.Surface anatomy

TUBEFOSITY OF THE TIBIA-16:32

ANTERIOR CEEST OF THE TIBIA-16:37

WEDIAL MARGIN OF THE TIBIA-16:36

BEDIAL SUKFACE OF THE TIBTA-16:33

IATERAL MALEEOLUS-16:57

IAEDIAL MALLEOLUS-16:40

TUBEROSITY OF THE NAVICULAR-17:23

TUBEROSITY OF THE FIFTH IETATARSAL EONE-17:36

c. Fegions

ANTERIOR CRURAL REGION-84:26

POSTERIOR CRURAL REGIOH-84:27

SURAL REGION-84:28

IATEFAL AHD PIEDIAL CRURAL REGIONS $-84: 29,30$

IATEFAL BRLLIEOLAR PEGION-84:31

MEDIAL MALLEOLAR REGION-84:32

LATERAL AND INEDIAL PETPOALLLEOLAR PEGTONS-84:33,34

CALCANEAI REGION-84:35

DORSAL ANI PLANTAR FEGIONS OF FOOT-84:36,37

DIGITAL REGIONS OF FOOT-84:38

DORSAL DICIT:L FEGIONS $-84: 39$

UNGUICULAP. REGIONS-84: 40

PLAITAR DIGITAL REGIONS OF FOOR-84:41

2. Anterior region of $\operatorname{leg}$ and dorsum of foot

2. Superficial fascia, cutaneous nerves and veins

Skir incisions; a) longitudinally along the median line of the leg and jorsum of the foot to the base of the middle toe; b) transversely across the ankle; c) transversely across the dorsum oi the foot at the bases of the toes; d) a medial longitudinal incision along the dorsal surface of each digit.

SUPERFICIAL FASCIA-23:36

DORSAL DIGITAL VEINS OF FOOT-56:15

INTERCAPITUIAR VEINS-56:11

CONON DIGITAL VEINS OF FOOT $-56: 9$

DORSAL VENOUS ARCH OF FOOT-56:8

DORSAI CUTANEOUS VENOUS NETMORK OF FOOT-56:7

SRALL SAPHENOUS VEIN-56:1 Origin only.

GREAT SAPHEHDUS VEIN-55:66 Origin only.

SAPHENOUS NERVE-70:44

MEDIAL CUTANEOUS RAII OF LEG-70:46

LATERAL SURAL CUTANEOUS NERVE-70:58 Terminal rami only.

SUPERFICIAL PERONEAL NERVE-70:60

DEEP PERONEAL NERVE-70:65 Terminal rami only.

DORSAL DIGITAL IERVES-70:64

LATERAL DORSAL CUTAIEOUS NERVE-71:5 

b. Deep fascia

DEEP FASCIA OF THE LIG-27:70

TRANSVERSE CRURAL LIGAMENT-27:73

DORSAL FASOIA OF FOOT-28:1

CRUC IATE LIGAIENT OF THE LEG-27:75

SUPER IOR PEROREAL RET INACUEURI-27:76

IYEERIOR PEPONEAL RETINACULUM-27:77

ANTERIOR FIBULAR SEPTUI-27:7I

POSTERTOR FIBULAR SEPTUI-27:72

coluscles in the anterior region of leg

Exposed by making a longltudinal incision through the deep

fascia on the front of the leg, extending from the knee to

the transverse crural ligament and reflecting the deep

fascia, but retaining intact the transverse and cruciate

crural ligaments.

TIBIALIS ANPERIOR IUSCLE-27:16

EXTENSOR DIGITORUM LOIGUS MUSCLE-27:17

EXTENSOR FALLUCIS IONGUS MUSCLE-27:19

PERONUUS TERTIUS INUSCLE-27:18

VAGINA TENDINIS NUSCULI TIBIALIS ANTERIORIS-29:29

VAGIHA TENDINIS MIUSCULI FYPTHSORIS HALLUCIS LONGUS-29:30

VAGINA TENDIIIS ITUSCUEI EXTENSORIS DIGITOROH PEDIS LONGI$29: 31$

d.Arteries

ANTER IOR TIBIAI ARTERY-52:I

Exposed by separating the extensor digitorum longus

from the tibialis anterior muscle.

ANTERIOR TIBIAL RECURPENT ARTERY $-52: 3$ Origin only.

LATERAI ANTERIOR MTLLEOLAR ARTERY $-52: 4$

NETIAS ANTERIOR MALLEOLAR ARTERY $-52: 5$

MEDIA MALLEOLAF NETTOET-52:6

IATEREI TALLEOLAR NETWORK-52:7

PERFORATIIG RAIUS OF THE PRRONEAL ARTERY-52:20 Termination only.

IORSAL ARTERY OF FOOT-52:8

LATERAL TARSAL FRTERY $-52: 9$

HEDIAL TARSAL ARTERIES-52:10

ARCUATE ARTERY-52:11

DORSAI NETWORK OF FOOT $-52: 12$

DORSAL NETATARSAL ARTERIES-52:13

DORSAL DIGITLL ARTERIES-52:14

DEEP PIANTAR PANUS-52:15

e. Nerves

DEEP PEROREAL NERVE-70:65

IIUSCULAR RAIII-70:66

DORSAL DIGITAL NERVES TO LATERAL SURFACE OF HALLUX

AIID TO MEDIAL SURFACE OF DIGIT II-70:67

SUPERFICIAI PERONEAL NEPVE-70:60

NIUSCULAR RA?I-70:61

IEDIAL DORSAL CUTÁIEOUS NERVE-70:62

INTERIEDIATE DORSAL CUTAIROUS NERVE-70:63

DORSAL DIGITAL NIERVES OF THE FOOT-70:64 

f.Muscles of the dorsum of the foot

EXTENSOR HA LLUCIS BREV IS MUSCLE-2 $7: 34$

EXPENSOR DIGITORUM EREVIS MUSCLE-27:35

Exposed by dividing the tendons of the muscles on the front of the leg at the level of the transverse cruciate ligament and reflecting the tendons toward their insertion.

DOPSAL IMIEROSSEOUS MUSCLES $-27: 47$

Denonstrated by dividing the tendons of the extensor digitorum brevis muscle and reflecting the muscle torra its origin; completing, at the same time, the exposure of the lateral tarsal artery, arcuate artery, and terminal rami of the disp peroneal artery.

3. Laterel or peroneel region of $l e g$

a. Deep fascia and muscles

ANTERIOF FIULAF ITTERTUSCULAR SEPTUM-27:71

Denonstrated by making a longitudinal incision through

the deep fascia of this region and reflecting the

fascia, retaining intact, however, the peroneal retinacula.

POSTERIOP PIBULAP INTERMUSCULAR SEPTUM-27:72

PERONEUS LOTGUS MUSCLE-27:20

PERONEUS BREVIS MIUSCLE-27:21

SJPERIOR FETINACULUM OF THE PERONEAL MUSCLES-27:76

INFER ICR RETINACULUM OF THE PEKONEAL MUSCLES-27:77

COMON SHEATH OF TENDONS OF THE PERONEAL MUSCLES-29:35

SUBCUTANEOUS BURSA OF THE LATEPAL MALLEOLUS-29:27

b.Nerves

C TNMTN PEF ONEAL NERTE-70:56

SUPERFICIAL PERONEAL IVERE-70: 60

MUSCULAR RA:II-70:61

DEEP PERONE: L NERVE-70:65

4. Medial region of leg

GPYAT SAPHENOUS VEII $-55: 66$

SA.PHENOUS INERVE-70:44

INFRAPATELLAR RAMUS $-70: 1.5$

MEDIAL CUTAIEOUS PAMI OF LEG-71:46

TENDONS OF INSERTION OF THE SAPTORIUS, GRACILIS AID SEMITENDINOSUS MUSCLES.

TIBIAL COLIATERAL LIGAIENT OF IKNEE JOINT-21:14

TEDDIAL INFERIOP GENICULAR ARTERY-51:69

5. Posterior region of leg and heel

a.Tascia, superficial veins and cutaneous nerves

Skin incisions: a) longitudinally in the middle line of the leg from the popliteal space to the heel; b) transversely at the distal end of (a) and extending $5 \mathrm{~cm}$. along the medial and lateral margins of the foot. 

SIALI SAPHENOUS TRIT-56:1

GPEAT SLPHEITOUS VBII $-55: 68$

SURN IERVE-71:3

IIEDTAI SUPAI CUPAINEOUS NBRVE-71:2

PERONELI ANASTOMOIIC ENIUS-70:59

LUTERAL SURAI CUTAIEOUS NEPVE-70:58

POSTWTIOR FEIORAL CUTANSOUS NPPVE-70:51

TEDIII CRUR:I CUTATEOUS KNII OF THE SAPHENOUS NERVE-70:46

WNEREOR FETCR.I CUTANEOUS NERVES-70:42 Heoial terminal rezi only.

DEEP FASCI: $=27: 74$

LAGINIATE LIGAIENT-27:74

b. Muscles; superficial group

Fxposed by dividing the deep fascic in the median line from the popliteal fossa to the heel and reflecting the fascia, but retaining intact the lacinate ligament.

TRICEPS IUSCIF OF TFE CLIF-27:22

GASTROCNITIUS INSCLE-27:22

I.TPRAI HE:D-27:24:

HIDI:L HWD-27:25

TITERII BURSA OF GASTPOCNEIIUS IUUSCIE-29:24

IEDI:A BUPS: OF GISRPOCIEITUS LUSCIE-29:25

SOLEUS IJUSCLE-27:26

Exposed by detaching the gastrocnemius at its attachment to the calcaneal tendon and reflecting it

proximaliy.

TEDIIOUS RCY OF THE SOZEUS ITSCIE-27:27

PITITILIS ITUSCLE-27:20

CAICANAI TEIDOH (OF ACHILTES) $-27: 28$

SUBCUTAPEOUS CALC-ITE:I, BURS:-20:29

BURS:- OF CAICATEII TEPDON-29:40

Denonstrated by dividing the calcaneal tendon

a fer centincters froll its insertion and reflecting the tendon.

c.Muscles; deep sioup

Structures sxposed by detaching the soleus muscle et its origin from the tibie, seprrating it from the tendinous arch, reflecting the muscle leterally, and making a longitudinal incision through the deep transverse fascia or septur betreen the superificial and deep group of ruscles of the back of the leg.

POPLITEUS ITUSC+E-27:50

BUPPSA OF POPLITTUS :IUSCIE-29:22

FLEXOR DIGITORIU: IONGUS IIUSCLE-27:32

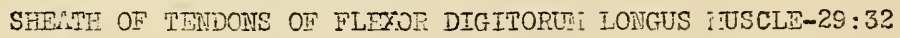

TIEINIIS POSTERIOR NUSCLF-27:31

SHEATH OF TENDON OF TIBI:TIS POSTERTOR IUSCLE-20:33

FLIXOR IEZIIUCIS LONGTS IJSCID-27:33

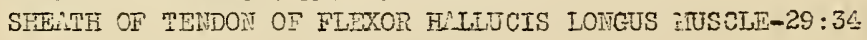

d.Arteries

POFIITEI ARTPPY-51:63 Termination onjy. NWTEIOE TIBIAY ARTRRY-5: I Origin only.

POSTERTOR TIBI: RECURRENT IRTEPY-52:2 

ANTER IOR TIBIAL LYPH GTAIND-57:6

POSTERIOR TIBIAL APPERY-52:16

FIBULAR RAIJS - 52:17

PERONEAL ARTPR $\mathrm{Y}-52: 18$

NUTRTEHT IRTEPY OF THE FIBULA-52:19

PERFARATIIG RAPUS $-52: 20$

CONMUNICAT ING RAITUS -52:21

LATERAL POSTERIOR IHILEOLR ARTERY-52:22

TATERAL CALCANEAL RAIMI-52:23

NUTRIENT ARTERY OF THE TIBIA-52:24

NEDTAL POSTERIOR MLLEOLAR ARTERY-52:25

TIEDIAL CATCANEAE RAMI-52:26

IIET TORK OF HEEL-52:27

$\frac{\text { e. Nerves }}{\text { MEIAL NARVE-70:68 }}$

MUSCULAP RAII-70:69

INTEEOSSEOLS NERVE OF LEG-71:1

NEDILL SUZE.L CUTANEOUS NAFTE-71:2

SUR:L BER: $E-71: 3$

f.Laciriate ?: igament $-27: 74$

6. Plantar region of tine poot

a.Fascia and sirocicial veins

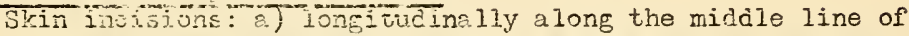
the sole; b) transversely across the sole at the clefts of the toes; c) longitudinally along the middle line of each toe.

SUPEFFICIAL F/SCI $-23: 36$

DIGITAL PINTH VEINS -56:16

PLATTAR VENOUS ARCH..56:13

INTEPC:PITULAR VEIIS-56:11

PLAITAR VEIOUS NETMORK-56:12

IVEDIEL CALCANELI DUTI OF THE TIBIAL NERVE-71:6

PLANTAR I.POINEUROSIS-28:2

TRIISVRSE FASICULI-28:3

\section{beliuscles; superficial layer}

ABDUCTOP HI ILTCIS INUSC LE-27:36

PLEXOR IIGITORUM BREVIS MUSCLE-27:44

VI.GINAT LIGAHEITT-28:6

ANNULUP LIGEIST:T-28:5

CKUCITE ICICATETT-28:7

DIGITAL SIERTS OF TENDOTS OF FOOT-29:44

ABDUCTOR DIGITI CUITTI HUSCLE-27:41

c. Plantar arteries

Exposed by detaching the preceding muscles at their origins and reflecting them toward their insertions (noting at the same time their norve supply).

DEDIAL PLWNTR RRTPPY-52:28

SUPERTICI T REMUS $-52: 30$

DEEP RIIUS-52:29

ILTERLL PIANTAR ARPERY-52:31 

d.Plantar Nerves

WEDIAL ? LANTER NERVE-71:7

COMON DIGITAL PIANTAR INERVES-71:8

PROPED DIGIEAT PLETIF NEPTES-71:9

IATERAL PLATILR NERVE-71:10

SUPERPICIAL RAITUS-71:11

COMON DIGTPAL PLEMTER INERVTS-?1:12

PROPEP DICIFISI PLIITLR NERVES-71:13

e. ifuscles; secand layer of muscles and tendons

TENDOIS OF THE FLXCR DIGITORTM LOMGUS DUSCLE-27:32

QUADPATIS PIANTEE MUSCLE-27:45

LUIRPICAIES IRUSCLES -27:46

BURSAE OF LUMBRICALES VUSCLES $-29: 13$

TERDON OF THE FLETCR FALLUCIS LOMEUS MUSCLE-27:33

foluscles; third laver

Exposed by dividing the tendons of the flexor digitorum

longus and slexor haliucis longus muscles, the heads of the quadratus plantae muscle, and the piantar vessels and nerves near the os calcaneum and reflecting these structures distally (noting at the same time the nerve supply to the lumbricales musclos).

FLEYOR HLLLUCIS RPUVIS TUSCLE-27:37

ADDUCIOR HALIUCIS MUSCIE-27:38

OBLIQJE HEAD-27:39

TRLNSVERSE HELD-27:40

FLF:-OR DIGIPI GUINTI BRETIS IIUSCLE-27:42

OPPGNETS DIGITI OUINTI I IUSCLE-27:43

5. Plantar arch anc deep division of the lateral plantar nerve Demonstrated by detaching the iexor halluis brevis muscle and the oilique head of the adductor hallucis muscle at their origins and reflesting them distally (identifying at the same tire the nerve supply of the latter muscle).

PLAITTAR ARCH-52:32

PLANTAR METATARSAL ARTERIES-52:33

PERFORATIITG RAMI-52:34

DIGITAL PLANTAR ARTERIES-52:35

DEEP BRANCH OF LATERAL PLANTAR NERVE-71:14

h. Interosseous muscles and deep tendons

TRANSVERSE LIGINENT OF THE HEADS OF THE ITERATAPSAL BONES22:21

PLANTAR INTEROSSEOUS IIUSCLES-27:43

DORSAL INTEROSSEOUS MUSCLES $-27: 47$

TENDON OF TIBIALIS POSTERIOR MUSCLE-27:31

TENDON OF PEKONEUS LONGUS MUSCLE-27:20

PLANTIR SHEATH OF TENDON OF PERONECS LONGUS MUSCLE$29: 41$

7. Articulations of the leg and foot

a. KNEE JOINT-21:3

ARTICULAR CAPSTEE-21:4

FIBULAR COLIATERAL LIGATENT-2 1:13 

TIBLAT COLLATERAL IIGANBIT-21:14

OBLIQUE POP UTTEAL LIGAMEHT-21:15

ARCUAPE PUELITEKL LIGANENT-21:16

LIGAMENT OF PHE FATELTA-21:18

MEDIAL PAIETLAR PEIIMACULUM-21:19

LATERAL PATELLAR RFTTITACULUI-21:20

The following structures may be exposed by making a longitudinal inciston on either side of the patella and patellar ligament, dividing the quadriceps extensor muscle about 8 $\mathrm{cm}$ a aove tho patella, and reflecting the patella and common extensor tencion disisally.

PATLLI:LR EYNOVILI, FOLD-21:11

DEEP IINRRPATELIAR EUISA-29:17

IATERAL TFE: ISCUS-2i:5

MEDIAL NOHISCUS $-2.2: 6$

TRAMSVERSE LIGANENT OF THE KNEE-21:7

CRUCIAME LIG MENTS OF THE INEE-21:8

ANTPRIOR SRUCIATE LIGN:ENT-21:9

POSTERTIR CRJCI:TE JIGMANT-21:10

SYNOV I I IE: BBRAIE- $18: 32$

b.Ank? joint-21:29

ARTICITIE CAPSTE-21:30

DELTOID LTGA.IFN $-21: 31$

IIBIONAVIOULIR IIGMEIJT-21:32

CALCN NECTIBIAL LEGSRESH:2:33

ANTUEIOR TALOT IBIAL LIGAMENT-21:34

PCSIERIOR TALOTIEIAI EIGAIENT-21:35

ANTERIOF TALOF IBULAR LIG 1 HEN $-2 I: 36$

POSMERIOR IALOFIBULR IIGNMENT-21:37

CALC $/ N$ NEOFIPULAR LIG MHENT -21:38

SYNOVILL INE IBR:NNE-18:32

colibiofitular jaints

TIBTOFIEUTR TIT TULATON-21:21

ALT:CU'AR CAPSULE-21:22

LIG 1 DUTS OF THE HEAD OF THE FIBUL/2-21:23

THTEP OSSEOUS IDENBRANE-21:24

TIBIOEIDJU:R SYIDESPIOSTS-\% $1: 25$

ANTER IOF LIGLMENT OF THE LATEPAL MLLLEOLUS-21:26

POSTERIOR LIGNMENT OF THE LATERLL MALEEOUS-21:27

d.Intertersal Articulations $21: 39$

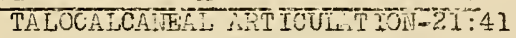

ARTICULAR CAPSUIS-2I:42

LATEFAL TALOC LOANEA L TIGMEIT-21:43

HEDIAL TALOCALCHEIL LIGANENT-2?:44

ANTEPIOE TILOCALCNTEAL LIGA:ETP $-21: 45$

POSTERTCR PALOC LCAIEAE LICAFENT-21:46

TALOCALC NIEOISVICOLR ARTTCULATON-21:40

DORBAL TALOHAV ICULAR IIGAMENT -21:58

APTICULAR CAPSULE OF THE TALONAVICULAP PART OF THE JOINT $-21: 49$

The exarination of the articulation may be completed by severing the ligaments holding the talus in place and removing the talus.

INTEROSSEOUS TALOC $\triangle$ LCANEAL IIGNMENT-2 1:54 

PLANTAR CAICNNEOHLTICULAR LIGAMENT-21:70

CALCANEONAVICULAR PFRT OF THE 3IFUPCATE LIGAIENT-21:62

DORSAL CALCAIRONAVICULAR LIGHAENT-2I:64

CHOPARI'S TRARSVIRSE ARTICULITI OF OF THE TARSUS-21:47

ThLOMAVICULAR ARTICULAFIOH-21:48

Note that this is a part of the talocalcaneonavicular articulation; attention has already been directed to its articular capsule in connection with the talocalcaneonavicular articulation.

CALAN NECUBOID ARTICULATION-21:50

ARTICUL:P. CAPSULE-21:51

PLINTER CALCANEOCUBOID LIGAMENT-21:69

LONG PLATTAR LIGAMENT-21:67

Not confined entirely to this articulation.

COIVEONAVIOULAR A.TICUTAT ION $-21: 52$

DCRSAL NATICULAR CUAEIFORT LIGAMENTS-21:65

PIAITAR NAVICULAR CUIEIFORA LIGAMBNTS-22:2

LIGANENTS CONUECING THE CUBOID, NAVICULAR AND CUNEIFOEI BONES;

DORSAL CUBOIDEONAVICULAR LIGAMENT -21:60

DORSA CUIECCUBOID LIGAMENT-2I:59

PLANIAR CUSOIDEONATICULAR LIGAMENT-22:3

PLANTAR CUTEOCUBCID LIGAMENT.22:5

PLANTAN INTERCUNEIFORI LIGAVENTS-22:4

IRTLPOSSEOUS CUNECCUBOID LIGRMENT -21:55

IINTEOSSEOUS INTERCUNGIFORM LIGANENTS-21:56

e. iarsometatarsal articulations-22:6

API ULA CIF IIA- 2.7

DORSEL TARSAIET TADSAL LIGAMENTS-22:8

PLETIAF TAFSOETIARSAL LIGANENS-22:9

INTEFOSSEOUS CUTEOETATARSAL LIGA TENTS-22:10

f. Intermetatarsa]. articilations-22:11

AFTECUR CAR

LORSAL IIUAIENTS OF THE BASES OF THE METATAPSAL BONES-

$22: 14$

PLAITAR LIG IIENTS OF THE BASES OF THE METATARSAL BONES-22:15

INTEROSSEOUS LIGANENTS OF THE BASES OF THE IMETATARSAL

BONES-22:13

INTEROSSEOUS SPACES OF NETATARSUS-22:16

g-Mietatarsopha langea I articulations-22:17

ARTIC ULAR CAPSUT:

COLLATERAL IIGAIEINTS-22:19

PLANTAR ACCESSOPY LIGAIEITS-22:20

TRAISVERSE LIGRIENTS OF IHE HEADS OF THE METAT RSAL BONES$22: 21$

h.Articulations of the toes-22:22

APTICULAR CASULE

CCLIATERHL LIGAEIVS-22:24 

Part Two

SYSTEMATIC ANATON $\mathrm{Y}$

- $\ldots . . . . . . . .-$ 

jostematic Anatomy ${ }^{1}$

1 NOMINA A N ATOMICA

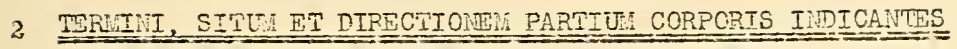

\section{Termini generales}

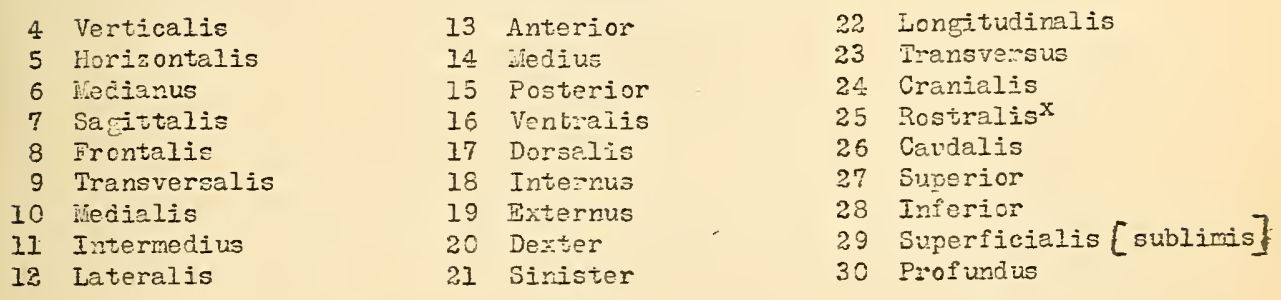

31 Termini ad extremitates spectantes

32 Proximalis

33 Distalis

34 Radielis
35 Unaris

36 Tibialis

37 Fibularis

I The folloving arrangement $c$ f terms is based on that of the $B$ iN A system as published by His in the Archï fir Anatomie und Intwicklungsgeschichte, supplerental Band, 1895.

All of the terme have been left in their original Latin form. Certain obvious errors in the original ísts (cf. also Pycleshymer's Anatomical Nanes, p. 2 , 1917) have been correctei as follows:

p. 20, lios. 34,35 corrected to read Ligg. instead of Lig.

p. 23, No3. 55, 55, 57 corrected to read in. instead of

p. 25, No. 49

p. 29, No. 4

p. 34, No. 65

p. 53, No. $74,75,76$

p. 55 , No. 71

p. 68 , No. 65 ,

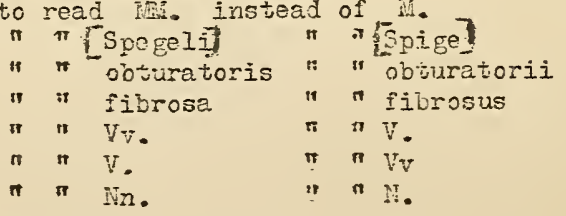

For the significance of brackets and asterisks see footnote, Part I, page 1. The prefixed munerals in Part II mereiy indicate the serial position of each term for cross reference purposes. 



\section{TRIJI GENEAIS}

2 Accessoríus

3 Acinus

4 Aditus

5 Ala

- Alveolus

7 Ampurla

8 Argulus

\& insa

10 Antrum

11 Axertura

12 Apex

I2 Appendix

14 Arcus

15 Area

16 Easis

17 Brachium

18 Canaijculus

19 Canalis

20 Capsula

21 Caput

22 Capitulum

23 Cartilago

24 Caruncula

25 Cauda

26 Caverna

27. Cavum

28 Cellula

29 Circulus

30 Cisterna

31 Collun

32 Columna

33 Comissura

34 Cornu.
35 Torona

36 Corpus

37 Corpusclilum

38 Crista

39 Crus

40 Decussatio

47 Dorsum

42 Ductulus

43 Ductus

44 Eninentia

45 Endothelium

46 Epithelium

4? Extremitas

48 Facies

49 Fascia

50 Fasciculus

51 Fibra

52 Eibrocartilago

52 Filum

$5 \div$ Fissura

55 Flexura

56 Folium

57 Folliculus

58 Foramen

59 Formatio

60 Fornix

61 Fissa

62 Fossula

ดิ3 Fovea

64 Foveola

65 Frenuium

66 Fundus

67 Funiculus
68 Geniculum

69 Cenu

70 Glandu?a

71 GlomeruI us

72 GIomus

73 Hilus

74 Humor

75 Junctura

76 Impressio

77 Incieura

78 InfundibuIum

79 Intestinum

80 Isthmt.5

81 Labium

82 Lacuna

83 Iamina

84. Latus

85 Ligamentum

85 Limbus

87 Limen

88 Linsa

89 jiquor

90 Lobulus

91 Lobus

92 Macula

93 Margo

94. Massa

95 Leatus

96 Nedulla

97 Niembrana

98 Membrum

99 Hucus

100 Musculus 

1 Nervus

2 Nodulus

3 Nucleus

4 Organon

5 Orificiun

6 Os [oris]

7 Os [ossis]

8 Ostium

9 Papilla

10 Parenchyma

11 Paries

12 Perichondrium

13 Periosteum

14 Plexus

15 Plica

16 Polus

17 Processus

18 Prominentia

19 Punctum

20 Radix

21 Ramulus

22 Ramus

23 Raphe

24 Recessus
25 Regio

26 Rete

27 Rima

¿8 Rundimentum

29 Septulum

30 Septum

31 Sinus

32 Spatium

33 Spina

34 Stratum

35 Stria

36 Stroma

37 Substantia

38 Succus

39 Sulcus

40 Taenia

41 Tegmen

42 Tela

43 Tela conjunctiva

44 Tela elastica

45 Torus

46 Trabecula

47 Tractus

48 Trigonum
49 Trochlea

50 Truncus

51 Tuber

52 Tivercul um

53 Tubulus

54 Tunica

55 Tusica propria

56 Umbo

57 Uvula

58 Vagina

59 Vallecula

50 vallun

61 Vaj.vula

62: Vas

63 Ve?um

64 Vertex

65 Vesica

66 Vesicula

67 Vestibulum

68 Villus

69 Viscus [viscera]

70 vortex

71 Zona 



\section{PAFTES CORPORTS H:MANJ}

2 Co.put

3 Jollum

8 Vetex

9 Sinciput

11 Dcciput

Io 0 ᄂ u 1 L.

17 Paplebra superior

18 Palpebra inferior

19 Rima palpebrarum

20 Bulbus ocili

21 Superciliurn

22 Sulcus infrapalpebralis $23 \mathrm{~N}$ a s $u s$

24 Dorsum nasi

25 Apex nasi

26 Ala nasi

40 Cervix

41 Larynx

42 Prominentia laryngea

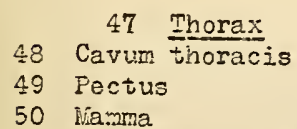

51 Papilla mamao

56 Cavum abdominis

57 Scrobiculus corcis

58 Umbilicus
4 Truncus

5 Extremitates

6 CAPUT

7 Criniur

15 Facies

$$
270 \mathrm{~s}
$$

28 Sulcus nasolabialis

29 Philitrum

30 Labjun superius

31 Labium inferius

32 Fire oris

33 Cavum oris

34 Lingua

35 Fauces

36 Bucca liala

37 Suicus mentolabialis

38 Nentum

39 COLLUE

43 Pharynx

44 Trachea

45 Oesophagus

46 TRUNCUS

\section{Dorsum}

53 Columia vertebralis

54 Canalis spinalis

\section{Abdomen}

$\begin{array}{ll}59 & \text { Latus } \\ 60 & \text { Iumbus } \\ 61 & \text { Inguen }\end{array}$ 



\section{.1 Pelvis}

2 Cavum pelvi:

3 lions pubis

4 Coxa

5 Niates [Clunes

10 Axilla

11 Plica axillaris anterior

Ii Plica axillaris posterior

13 Acromion

14 Brachium

15 Facies anterior

i6 Facies posterior

17 Facies lateralis

16 Facies modialis

19 Sulcus bicipitalis lateralis

20 Sulcus bicipitalis medialis

21 Cubitus

22 Antibrachium

23 Facies dorsalis

24 Facies volaris

25 Nargo radialis

26 Nargo ulnaris
6 Anus

7 Crena ani

8 Perineum

9 EXTREMITAS SUPERIOR

27 Mianus

28 Carpus

29 Netacarpus

30 Dorsun rinus

31 Vole ianue Palma

32 Therar

33 Hypoihenar

34 Digiti manus

35 Bollex EDigitus I

30 Inciex $\bar{E} \quad I]$

37 Digitus medius Digitus III

38 Digitus annularis ${ }_{39}$ Digitus minimus $[$ IV 40 Facies dorsales

41 Facies volares

42 Nargines radiales

43 Nargines ulnares

44 EXTREMITAS INEERIOR

45 Femur

46 Facies anterior

47 Facies posterior

48 Facies lateralis

49 Facies medialis

50 Sulcus gluteeus

51 Genu

52 Poples

53 Patella

54 Crus

55 Facies arterior

56 Facies posterior

57 Sura

58 Malleolus lateralis

59 Malleolus medialis
61 Tarsus

62 Metatarsus

63 Dorsum pedis

64. Planta

65 Margo pedis lateralis

66 Nargo pedis medialis

67 Calx

68 Digitj pedis

69 Hallux [Digitus I]

70 Digiti II-IV

71 Digitus minimus [Digitus $V$ ]

72 Facies dorsales

73 Facies plantares

74 Nargines laterales

75 Nargines modiales

60 Pes 



\section{CSTEOLOCIA}

2 Os longum

3 Os breve

4 Os planum

5 Os pneumaticum

6 Epiphysis

7 Diapinysis
8 Synchondrosis epiphyseos

9 Apophysis

10 Facies articularis

11 Sicstantia compacta

12 Suiostantia corticalis

13 Syòstantia spongiosa
14 Cavum meduliare

1.5 Meciulla ossium

16 Meculia ossium flava

17 Mecul-1a oseilun I'iura

18 Foramen nutrisium

19 Canalis nutricius

\section{COLURANA VERTEBRALIS}

2I. Vertebrae cervicales

22 Vertebrae thoracaies

23 Vertəbrae Iumbaies

24 Vertebrae sacralos

25 Vertabrae coccygeae

26 Corpus vertebrae

27 Fovea costalis superior

28 Fovea costalis inîrior

29 Canalis vertebralis

30 Foramen vertebrale

31 Arcus vertebrae

32 Radix arcus vertebrae

33 Incisura vertebralis superior

34 Incisura vertebralis inferior

35 Foramen intervertebrale

36 Sulcus n. spinalis

37 Processus spinosus

38 Vertebra prominens

39 Processus transversus

40 Fovea costalis transyersalis

41 Tuberculum anterius [vertebrarum cervicalium]
42 Tuberculum caroticum [vertebrae cervicalis VI?

43 Foramen transversarim

44 Tuberculam postisius [vertebrarum cervicalius]

45 Processus articulares superiores

46 Facies articulares superiores

47 Processus articulares inferiores

48 Facies articuleres inferiores

49 Processus costarius

50 Processus accessorius vertebrarum I unioalium]

51 Processus iramillaris

\section{Aulas}

53 Massa lateralis

54 Arcus anterion

55 Tuberculum anterius

56 Foveae articulares superiores

57 Facies articulares inferiores

58 Favea dentis

59 Fovea posterior

60 Sulcus arteriae vertebralis

61 Tuberculum posterius 

1 Epistropheus

2 Dens

3 Facies articularis anterior

4 Facies articularis posterior

\section{Os sacrum}

6. Facies dorsalis

7 Facies peivina

8 Basis oss. sacri

9 Processus articularis superior

10 Promontorium

11 Pars lateralis

12 Facies auricularis

13 Iuberositas sacralis

14 Forsmina intervertebralia

15 Foramina sacralia anteriora

16 Lineae transversae

17 Foramina sacralia posteriora

18 Crista sacralis media

19 Cristae sacrales laterales

20 Cristae sacrales articulares

21 Cornua sacralia

22 Canalis sacralis

23 Hiatus sacralis

24 Âpex oss, sacri

\section{Ds coccugis}

26 Cornua coccygea

27 TEFORAX

28 Cc3tas

29 Costae verae

30 Costae spuriae

31 Os costalo

32 Cartilago costalis

33 Capitulum costae

34 Facies articularis capituli costae

35 Crista capituli

36 Corpus costae

37 Tuberculum costae

38 Facies articularis tuberculi costae
39 Collum costae

40 Crista colli costae

41 Angulus costae

42 Tuberculur scaleni [Iisfranci]

43 Sulcus subclaviae

44 Tuberositas costae II

45 Sulcus costae

\section{Sternum}

47 Nanubrium sterni

48 Angulus sterni

49 Synchondrosis sternalis

50 Corpus sterni

51 Planum sternaie

52 Processus xiphoideus

53 Incisura clavicularis

54 Incisura jugularis

55 Incisurae costales

56 (Ossa suprasternalis)

$$
57 \text { I h } \circ \text { i } x
$$

58 Cavum thoracis

59 Apertura thoracis superior

60 Apertura thoracis inferior

61 Arcus costarum

62 Spatia intercostalia

63 Angulus infrasternalis

64 Sulcus pulmonalis

65 OSSA CRANII

66 Os basilare

67 Os occipitale

68 Foramen occipitale magnum

69 Pars basilaris

70 Sulcus petrosus inferior

71 Pars lateralis

72 Squama occipitalis

73 ilargo mastoideus

74 Margo lambdoideus

75 (0s interparietale) 

1 CIivus

2 Tuberculum pharyngeum

3 Condylus occipitalis

4 Canalis condyloideus

5 Canelis hypoglossi

6 Tuberculum jugulare

7 Incisura jugularis

8 Processus jugularis

9 Fossa condyloidea

10 Frocessus intrajugularis

11 Plarum occipitale

12 Planum muchale

13 Pro uberantia occ pitalis externa

14 (Torus occipitalis)

15 Crista occipitalis externa

16 Linea nuchae suprema

17 Linea nuchae superior

18 Linea nuchae inferior

19 irinentia cruciata

20 Protuberantia occipitalis interna

21 Sulcus sagittalis

22 Sulcus transversus

23 (Processus paramastoideus)

24. Os sphenoidale

25 c o: $r$ p us

26 Sella turcica

27 Fossa hypophyseos

28 Dorsum sellae

29 Tuverculum sellae.

30 Processus clinoideus medius

31 Processus clinoideus posterior

32 Sulcus caroticus

33 Iingula sphenoidalis

34 Crista sphenoidalis

35 Rostrum sphenoidale

36 Sinus sphenoidalis

37 Septum sinuum spheroidalium

38 Apertura sinus sphenoidalis

39 Conchae sphenoidales

40 Clivus

$41 \mathrm{~A} I$ a parva

42 Sulcus csiasmatis
43 Foramen opticum

44 Processus clinoideus anterior

45 Fissura orbitalis superior

46 A I a m a $\mathrm{g} \mathrm{n}$ a

47 Facies cerebralis

48 Facies temporalis

49 Facies sphenomaxillaris

50 Facies orbttalis

51 Margo zygomaticus

52 largo frontalis

53 Angulus parietalis

54 Margo squamosus

55 Crista infratemporalis

56 Foramen rotundum

57 Foramen ovale

58 Forauen spinosum

59 Spina angularis

60 P r c e s us pterygoide us

61 Lamina lateralis processus pterygoidei

62 Lamina medialis processus pterygoidei

63 Fissura pterygoidea

64 Fossa scaphoidea

65 Processus vaginalis

66 Hamulus pterygoideus

67 Sulcus hamuli pterygoidei

68 Fossa pterygoidea

69 Canalis pterygoideus Vidil

70 Canalis pharyngeus

71 Canalis basipharyngeus

72 Sulcus tubae auditivae

73 Sulcus rterygofalatinus

74 (Processus pterygospinosus

$$
\text { [Civinini]) }
$$

75 Os Temporale

76 Pars mastoi d e a

77 ilargo occipitalis

78 Processus mastoideus

79 Incisura mastoidea

80 Sulcus sigmoideus 

1 Sulcus 2. occiptelis

2 Foramen mastoideum

3 pars petros a [Pyramis]

4 Facies anterior pyramidis

5 Facies posterior pyramidis

6 Facies inferior pyramidis

7 Apex pyrarnidis

8 Angulus superior pyramidis

9 Anguius anterior pyramidis

10 Angulus posterior pyramidis

11 Sulcus petrosus superior

12 Tegmen tympani

13 Iminentia arcuata

14 Canalis facialis Falloppii

15 Hiatus canalis facialis

16 Geniculum canalis facialis

17 Sulcus $n$, petrosi superficialis majoris

18 Sulcus $n$. petrosi superficialis minoris

19 Impressio trigemini

20 Porus acusticus internus

21 Neatus acusticus internus

22 Fossa subarcuata

23 Aquaeductus vastzbuli

24 Apertura externa aquaeductus vestibuli

25 Sulcus petrosus inferior

26 Incisura jugularis

27 Processus intrajugularis

28 Fossa jugularis

29 Canaliculus mastoideus

30 Sulcus canaliculi mastoidei

31 Processus styloideus

32 Vagina processus styloidei

33 Foramen stylomastoideum

34 Fossula petrosa

35 Canaliculus tympanicus

36 Sulcus tympanicus

37 Apertura inferior canaliculi tympanici

38 Apertura superior canaliculi tympanici

39 Canaliculus cochleae

40 Apertura externa canaliculi cochleae
41 Canalis caroticus

42 Canaliculi caroticotympanici

43 Canalis musculotubarius

44 Semicanalis $\mathrm{m}$. tensoris tympani

45 Semicanalis tubae auditivae

46 Septum canalis musculotabarii

47 Cavum tympani (v. Organon auditus)

48 Canaliculus chordae tympani

49 Fissura petrotympanica (Glaseri

50 Fissura petrosquamosa

$51 \mathrm{Pars}$ t y m a nica

52 Annulus tympanicus ${ }^{x}$

53 Meatus acusticus externus

54 (Spina supra meatum)

55 Fissura tympanomastoidea

56 Spina tympanica major

57 Spina tympanica minor

58 Porus acusticus externus

59 S q u a $\mathrm{m}$ t $\mathrm{e} \mathrm{mporal}$

60 Margo parietalis

61 Incisura parietalis

62 Margo sphenoidalis

63 Facies temporalis

64 Processus zygomaticus

65 Fossa mandibularis

66 Facies articularis

67 Tuberculum articulare

68 Facies cerebralis

69 Sulcus 2. temporalis mediae

\section{Os parietale}

71. Facies cerebralis

72 Facies parietalis

73 Nargo occipitalis

74 Margo squamosus

75 Nargo frontalis

76 Nargo sagittalis

77 Anguius frontalis

78 Angulus occipitalis

79 Angulus sphenoidalis

80 thngul us mastoideus

81 Foramen parietale 

1 Tuber parietale

2 inea temporalis infericr

3 Linea temporalis superior

4 Sulcus sa gittalis

5 Sulcus transversus

\section{Os frontale}

7 Squama frontais

8 Facies frontalis

9 Har jo supraorbitalis

10 Parz orbitalis

11 Incisura ettanoidalis

12 Pars nasalis

13 Sina frontalis

14 Margo nasalis

15 Margo parietalis

16 Processus zygomaticus

17 Facies temporalis

18 Iinea teriporalis

19 Tuber frontale

20 Arcus superciliaris

21 Glabella

22 Foramen sive Incisura supraorbitalis

23 Incisura sive Foramen frontale

24 Facies orbitalis

25 (Spina trochlearis)

26 Fovea trochlearis

27 Foramen ethmoidale anterius

28 Foramen ethmoidale posterius

29 Fossa glandulae lacriralis

30 Facies cerebralis

31 Crista frontalis

32 Sulcus sagittalis

33 Foramen caecum

34 Sinus frontalis

35 Septum sinuurn frontaliun

37 Lamina cribrosa

36 Os ethmoidale

38 Crista galli

39 Processus alaris

40 Lamina perpendicularis
41. Labyrinthus ethroidalis

42 Ceiculae ethnoidales

43 Infundibulum Ethrnoidale

44. Hiatus semilunaris

45 Bulla ethmoidalis

46 Lamina papyracea

47 Foramina ethmoidalia

48 (Concha nasalis suprema)

49 Concha nasalis superior

50 Concha nasalis media

51 Processus uncinatus

52 Concha nasalis inferior

53 Processus lacrimalis

54 Processus maxillaris

55 Processus ethmoidalis

56 Os lacrimale

57 Crista lacrimalis posterior

58 Sulcus lacrimalis

59 Hamul us lacrimalis

60 Fossa sacci lacrimalis

61 Os Nasale

62 Foramina nasalia

63 Sulcus ethmoidalis

65 Ala vomeris

64 Vomer

66 OSSA FACIEI

67 liaxilla

68 Corpus maxillae

69 Facies anterior

70 Facies nasalis

71 Facies orbitalis

72 Facies infratemporalis

73 Sinus maxillaris

74 Nargo infraorbitalis

75 Canalis infraorbitalis

76 Sulcus infraorbitalis

77 Foramen infraorbitale

78 Sutura infraorbitalis

79 Fossa canina 

1 (Fossa praenasalis)

2 Incisura nasalis

? $\because \cdots: \because: 9 x+7$ ? r.juina alveolaria

5 Canales alveolares

- Plenum orkitale

- argo zacrimelis

8 Sulcus lacrinalis

- Canalis rasolacrimalis

10 Crista conchalis

II Processus frontalis

12 Cricta lacrimalis enterior

13 Incisura lacrimalis

14 Crista ethmoidalis

15 Processus zygomaticus

16 Processus palatinus

17 Crista nasalis

18 Spina nasalis anterior

19 Cos incisivum $x$

20 Canalis incisivus

21 Sutura incisiva

22 Spinae palatinae

23 Sulci pałatini

24 Processus alveolaris

25 Limbus alveolaris

26 Alveoli dentales

27 Septa interalveolaria

28 Juga alveolaria

29 Hiatus maxillaris

30 Foramen incisivum

$3 i$ Os nalatinum

32 pars perpendicularis

33 Facies nasalis

34 Facies maxillaris

35 Incisura sphenopalatina

36 Sulcus pterygopalatinus

37 Processus pyramidalis

38 Foramen palatinum sajus

39 Foramina palatina minora

40 Canales palatini

41 Crista conchalis

42 Crista ethmoidalis
43 Processus orbitalis

14 Processus spienoidalis

45 Pars norizontalis

46 Fucies nasalis

47 Facies palatina

48 Spina nasalis posterior

49 Crista nasalis

50 Os z Veromaticum

51 Facies lataris

52 Facies temporalis

53 Facies orbitailis

54 Processus te:nnoralis

55 Processus frontosphanoidalis

56 (Processus marginalis)

57 Foramen zygcraticoorbitale

58 Foramen zygomaticofaciale

59 Foramen zygomaticotemporale

60 Nandihula

61 Corpus rardibulas

62 Basis mandibulae

63 Protuberantia mentalis

64 Tuberculum mentals

65 Spina. mentalis

66 Foramen mentiale

67 Linea obliqua

68 Fossa dig:strica

69 Linea mylohyoidea

70 Sulcus mylohyciders

71 Juga alveslaria

72 Ramus mandibulas

73 Argulus manibibulae

74 (Tuberositas masseterica)

75 (Tuberositas pterygoidea)

76 (Crista buccinatoria)

77 Incisura randibulas

78 Processus condyloideus

79 Capituium proc. condyl. mandibulae

80 Collum proc. condyloidei mandibulas

81 Fovea pterygridea proc. conaylujidei

82 Processus coronoideus 

1 Foramen mandibulare

2 Lingula mandibulae

3 Canalis mandibulae

4 Forea sublingualis

5 (Forea submaxiliaris)

6 Pare alveolaris

7 ininbus alveolaris

8 Aveoli dentales

9 Senta interaiveolaria

11 Curpus oss. hyo:dei

12 Cornu minus

13 Cornu rajus

14 CRANIUN

15 Calvaria

10- Pericranium

17 Lamina externa

18 Diplob

19 Canales diploici Brescheti]

20 Lamina interna

21 Facies [ossea]

22 Cranium cerebrale

23 Cranium viscerale

24 Vertex

25 Frons

26 Occiput

27 Basis cranii interna

28 Bassis cranii externa

29 Fossa cranii anterior

so Fossa cranii media

31 Fossa cranii posterior

32 Jugz cesekzalia

33 Impressiones digitatae

34 Sulci venosi

35 Sulci stoteriosi

30 (Foveosae granulares [Pacchioni])

37 (Os:a suturarun:)

38 Planum temporale

39 Fossa temporalis

40 Arcus zygomaticus

41 Fossa infratemporalis
42 Fossa pterygopalatina

43 Caralis pterygupalat

44 Foramen sphenopalatinum

45 Apertura piriformis

46 Cavurn nasi

47 Septum nasi osseum

48 Neztus nasi communis

49 Meatus nasi superior

50 ileatus nasi reciius

51. Meatus nasi inferior

52 Meatus nasopharyngeus

53 Choanae

54 Recsucus sphenoethmoidalis

55 Foramen jugulare

56 Fissura sphenopetrosa

57 Fissura petroxccipitalis

58 Fissura splenooccipitalis

59 Foramen lacerum

60 Fibrocartiiago basalis

61 Palatum curum

62 (Torus palatinus)

63 Oribita

64 Aditus orbitae

65 Niergo supraorbitalis

66 Niargo infraorbitalis

67 Paries siperior

68 Paries inferior

69 Paries lateralis

70 Paries medialis

71 Fissura orbitalis superior

72 Fissura orbitalis inferior

73 Suturae cranii

74 Sutura coronalis

75 Sutura sagittalis

76 Sutura lambdoidea

77 Sutura occipitomastoidea

78 Sutura sphenofrontalis

79 Sutura sphenoorbitalis

80 Sutura sphenoethmoidalis

81 Sutura sphenosquamosa

82 Situra sphenoparietalis 

1 Sutura squamosa

2 (Sutura frontalis)

3 Sutura parietomastoidea

4 (Sutura squamosomastoidea)

5 Sutura nasofrontalis

6 Sutura frontoethmoidal is

7 Sutura frontomaxillaris

8 Sutura frontolacrimalis

9 Sutura zygomaticofrontalis

10 Sutura zygomaticomaxillaris

11 Sutura ethmoide omaxillaris

12 Sutura sphenozygomatica

13 (Sutura sphenoraxillaris)

Is Sutura zygoraticotemporalis

15 Sutura internasalis

16 Sutura nasomaxillaris

17 Sutura lacrimomaxillaris

18 Sutura lacrimoconchalis

19 Sutura intermaxiilaris

20 S!itura nalatonayillaris

21 Sutura palatoethmoidalis

22 Sutura palotina mediana

23 Sutura palatina transversa

\section{Syhchonäroses cranii}

25 Syachondrosis sphenooccipitalis

25 Synchondrosis sphenopetrosa

27 Synchondrosis sphenopetrosa

28 Synchondrosis intraoccipitalis posterior $x$

29 Eynchondrosis intraoccipitalis anterior $x$

30 Synchondrosis intarephecoidaiia ${ }^{*}$

31 Fonticulus frontalis major $x$

32 Fonticulus occipitalis minor $x$

33 Fonticulus mastoideus $x$

34 Fonticulus spheroidalis $x$

35 OSSA EXTREMITATIS SUPERJORIS

36 Cingulum extremitatis superioris
40 Fossa subscapularis

41 Euries dorsalis

4? Spino siepulae

43 Fossa supraspinata

44 Fossa infraspinata

45 Acromion

46 Facies articularis acromii

47 Margo vertebralis

48 Nargo axillaris

49 ifargo superior

50 Angulus inferior

51 Angulus lateralis

52 Angulus medialis

53 Cavitas glenoidaiis

54 Collum scapulae

55 Tuberositas infraglenoidalis

55 Tuberositas supragleroidalis

57 Incisura scapuiae

58 Processus coracoideus

59 Ciavicula

60 Extrenitas sternalis

61 Facies articularis sternalis

62 Tuberositas costalis

63 Extremitas acromizilis

64. Facies articularis acromialis

65 Tuberositas coracoidea

$66 \mathrm{ske} l$ e ton extremitatis perioris I i b e $r$ a e

68 Caput humeri

69 Collum anatomicum

70 Collum chirurgicum

71 Tuberculum majus

72 Tuberculum minus

73 Sulcus intertubercularis

74 Crista tuberculi majoris

75 Crista tuberculi minoris

76 Corpus humeri

38 Facies costaís

39 Lineae musculares 

1 Facies anterior medialis

2 Facies anterior laterais

3 Facies posterior

4 llargo medialis

5 Margo lateralis

6 Tuberositas deltoidea

7 Sulcus $n$, radialis

8 Sulcus n. ulnaris

9 Capitulum humeri

10 Trochlea humeri

11 Epicondylus medialis

12 Epicondylus lateralis

13 Fossa olecrani

14 Fossa coronoidea

15 Fossa radialis

16 (Processus supracondyloideus)

18 Corpus radii

19 Capitulum radii

20 Fovea capituli radii

21 CnI?um madi

22 Circumferentia articularis

23 Tuberositas radii

24 Crista interossea

25 Facies dorsalis

26 Facies volaris

27 Facies lateralis

28 Nargo dorsalis

29 Margo volaris

30 Pro:ussus styloideus

31 Incisura ulnaris

32 Facies articularis carpea

33 Ulna

34 Corpus ulnea

35 Olecranon

36 Processus coronoideus

37 Tuberositas ulnae

38 Incisura semilunaris

39 Incisura radialis
1C Crista interossea

$\dot{y}$ Facies dorsalis

42 Facies volaris

43 Facies metialis

44 Narfo dorsalis

45 largo volaris

46 Crista $\mathrm{m}$. supinatoris

47 Capitulum ulnae 48 Circunferentia articularis

49 Processus styloideus

50 Carpus

$510 s \mathrm{~s}$ a carpi

52 (Os centrale)

53 Os naviculare manus

$\because 54$ Tuberculum oss. navicularis

55 Os Iunaturn

56 0s triquetrum

57 Os pisiforme

58 Os multangulum ta jus

59 Tuberculum oss . multanE. Ing joris

60 Os multangulum minus

61 Os capitatum

62 Os hamatum

63 Famulus oss. hamati

64 Eminentia carpi radialis

65 Eminentia carpi ulnaris

66 Sulcus carpi

67 Metacarous

68 Ossa metacarpalia I--V

69 Basis

70 Corpus

71 Capitulum

72 Os metacarpale III

73 Processus styloideus

74 Phalanges digitorum manus

75 Phalanx prina

76 Phalanx secunda

77 Phalanx tertia

78 Basis phalangis 

1 Corpus phalangis

2 Trocnea phalangis

3 Tuberositas unguicularis

4 Ossa sesamoidea

5 OSSA EXTRENITATIS INIERIORIS

6. ingulum extremitatis inf $f r i \circ r$ s

\section{Os coxae}

8 Foramen obturatum

9 Acetabulum

10 Iossa acetabuli

11 Incisura acetabuii

12 Facies Iunata

13 Sulci paraglenoidales

\section{Os ilium}

15 Corpus oss. ilivit

13 A?: 0sะ. Iitun

17 Linea arcuata

18 Crista iliaca

19 Labium extrenum

20 Lirea intermedia

21 Labium internum

22 Spina iliaca anterior superior

23 Spina iliac anterior inferior

24 Spina iliaca posterior superior

25 Spina iliaca posterior inferior

26 Lirea glutaea anterior

27 Linea glutaea posterior

28 Iinea glutaea inferior

29 Facies auricularis

30 Tuoerositas iliaca

31 Fossa iliaca

\section{Os ischii}

33 Corpus oss. ischii

34 Ramus superior oss. ischii

35 Ramus inferior oss. ischii

36 Tuber ischiadicum

37 Spina ischiadica
38 Ineisura ischiadica major

39 Incisura ischiadica minor

41 Corpus oss. pubis

42 Pecten oss. pubis

Ercinentia iliopectinea

44 Tuberculum pubicum

45 Crista obturatoria

46 Sulcus obturatorius

47 Tuoerculum obturatorium anterius

48 (Tuipersulum obturatorium posterius)

49 Ramus inferior oss. pubis

50 Ramus superior oss. pubis

51 Facies symphyseos

\section{PeIvis}

53 Symphysis ossium pubis

54. Areus pubis

55 Angulus pubis

56 Pelvis major

57 Pelvis minor

58 Linea terminalis

59 Pars sacralis

60 Pars iliaca

61 Pars pubica

62 Apertura pelvis [minoris] superior

63 Apertura peivis [minoris] inferior

64 Axis pelvis

65 Conjugata

66 Diameter transversa

67 Diameter obliqua

68 Inclinatio pelvis

69 S k e l e ton extremitatis inferioris 1 i b e r $a$ e

\section{Femur}

71 Caput femoris

72 Fovea capitis femoris

73 Coilun femoris 

1 Corptis femoris

2 Brochanter major

3 Fossa trochanterica

4 Trochanter minor

5 (Trochanter tertius)

o Linea intertrachanterica

7 Crista intertrochanterica

8 Linea aspera

9 Labium lateralo

10 Labium mediale

11 Linea pectinea.

12 Tuberositas glutaea

I3 Fossa intercondyloidea

14 Linea intercontyloides

15 Planum popliteum

16 Condylus redialis

17 Condylus lateralis

18 Facies patellar:s

19 Epirondilu laveris is

20 Epiconaylus medialis

21 Tibia

22 Facies articularis superior

23 Corpus tibiae

24 Condylus medialis

25 Condylus lateralis

26 Fossa intercondyloidea anterior

27 Fossa intercondyloidea posterior

28 Eminentia intercondyloidea

29 Tuberculum intercondyloideum mediale

30 Tuberculum intercondyloideum laterale

31 Nargo infraglenoidalis

32 Tuberositas tibiae

33 Facies redialis

34 Facies posterior

35 Facies lateralis

36 Margo medialis

37 Crista anterior

38 Crista interossea
39 Linea poplitea

AC Ne Iou?ue medialis

41 Incisura fibularis

42 Sulcus malleolaris

43 Facies articularis inferior

44 Facies articularis malleolaris

46 Corpus fibulae

47 Crista Enterossea

48 Crista anterior

49 Crista iaterais

50 Crista medialis

51 Facies medialis

52 Facies lateralis

53 Faciss posterior

54 Capitulum fibulio

55 Facies articuiaris cepituli

56 Apex capituli fibulae

57 Mrlleolus lateralis

58 Facies articularis malleoli

59 Patella

60 Basis patellae

61 Apex patellae

62 Facies articularie

63 Tarsus

640 s s a tars i

65 Talus

66 Caput tali

67 Corpus tali

68 Collum tali

69 Trochlea tali

70 Facies superior

71 Facies malleolaris medialis

72 Facies malleolaris lateralis

73 Sulcus tali

74 Processus lateralis tali

75 Facies articularis calcaneo posterior 

1 Facies articularis calcanea media

2 Silcus $\mathrm{n}$. Ilexoris hallucis longi

3 Facies articularis navicularis

4 Facies articularis calcanea anterior

5 Processus posterior tali

6 (os trigonum)

8 Corpus calcano:

7 Calcaneus

9 Tuler calcanei

10 Processus medialis tuberis calcanei

11 Processus lateralis tuberis calcanei

12 Sustentaculum tali

13 Sulcus m. flexoris nallucis long:

14 Sulcus calcanei

15 Sinus tarsi

16 Facies articularis anterior

17 Facies articularis media

18 Facies articuleris posterior

19 Sulcus $\mathrm{ra}$. peronae:

20 (Processus trochlearis)

21 Facies articularis cuboidea

22 Os naviculare vedis

23 Tuberositas oss. navicularis

23 Tuberositas oss.
24 Os cuneiforme primur

25 Os cuneiforme secundum

26 Os cuneiforme tertium

28 Sulcus m. peronaei

29 Tuberositas oss. cuboidei

30 Netatarsus

31 Ossa metatarsalis $\mathrm{I}=-\mathrm{V}$

32 Basis

33 Corpus

34 Capitulum

35 Tuberositas oss. metatarsalis I

36 Tuberositas oss. metatargaiis $\mathrm{V}$

37 Fhalanges digitorum pedis

38 Phalanx prima.

39 Phalanx secunda

40 Phalanx teriia

41 Tuberositas unguicularis

42 Easis phalangis

43 Corpus phalangis

44 Trochlea phalangis

45 Ossa sesamoidea 



\section{SYNDESMOLOGIA}

2 Junctura ossium

3 Synarthrosis

4 Sutura

5 Sutura serrata

6 Sutura squamosa

7 Harmonia

3 Gompiosic

9 Synchondrosis

10 Syophysis

11 Diarthrosis

12 Articulatio

13 Articulatio simplex

14 Articulatic composita

15 Arthrodia

16 Articulatio sphaeroidea

17 Enarthrosis

I8 Ginglynus

19 Articulatio coehlearis

20 Articulatio ellipsoidea

21 Articulatio trochoicea

22 Articulatio sellaris

23 Amphiarthrosis

24 3yndesmosis

25 Cartilago articularis

26 Gavum articulare

27 Discus ก:tículute

28 Labrur glenoitule

29 heniscus articularis

30 Capsula articularis
31 Stratum fibrosum

32 Stratura synoviale

33 Plica strnovialis

34 Villi synoviales

35 Synovia.

36 LIGANENTA COLLIMAE VERTEBRALIS ET CRANII

37 Fibrocartilagines intervertebrales

38 Annulus fibrosus

39 Nucleus pulposus

40 Ligg. flava

41 Capeulae articulares

42 LigE. intertransversaria

43 iigg. interspinalia

44 Lig. supraspinale

45. Liö. nuchae

$46 \mathrm{Lig}$. Iongitudinale anterius

47 Lig. Iongitudinale posterius

48 Symphysis sacrococcygea

49 Lig. sacrococcygeur posterius superificiale

50 Lig. sacrococcygeum posterius prof und um

51 Lig. sacrococcygeum anterius

52 Lig. sacrococcygeum laterale

53 Lig. pterygospinosum

54 Lig. stylohyoideum 

1 ARTICULATIO ATLF NTOOCCIPITALIS

2 Cepsulae articulares

3 Wemorane atiantooccipitabis anterior

4 Membrana atlantooccipitalis posterior

5 ARTICULATIO ANIANTOEPISTROPHICA

6 Capsulae articulares

7 İigg. alaria

8 i.ig. apicis dentis

9 Isig. transversum atiantis

10 Is. . cruciatum atlantis

11 Nierbrana tectoria

\section{ARIUULATIOES COETOVERTEBRALDS}

\section{ARTICULATIONES CAPITULORUN}

14 Capsulae articulares

15 Iig. canituii costae reqiaturn

16 iig. capituli costae interarticulare

\section{ARIICULAIIOIES COSTOMRA:TSVERSA-} RIt T.

18 Censulae articulares

19 Lig. tuberculi costae

20 Lig. colli costae

21 Lig. costotransversarium anterius

22 Lig. costotransverserium posterius

23 Lig. lunbocostale

24 Foramen costotransversarium

25 ARTICUEATIONES STERHOCOSTALES

26 Capsulae articulares

27 Lig. sternocostale interarticulare

28 Ligg. sternocostalis radiata

29 Nembrana sterni

30 Ligg costoxiphoidea

31 Ligg. intercostalia

32 Ligg. intercostalia externa

33 Ligg. intercosta?ia interna

34 Articulationes interchondrales

\section{ARTICIILTIO NANDIBULARIS}

36 Capsuia articularis

37 Discus articularis

38 Lig. temporomandibulare

39 LiE. sphenorandibulare

40 Iig. stylorandibulare

\section{IIGG. CINGUTI EXTREMITATIS} SUPERIORIS

42 Lig. coracoacromiale

43 Lig. transversum scapulae superius

44 Lig. transversim scapulae inferius

\section{ARTICULATIO ACROMIOCLAVICULARIS}

46 Capsula articularis

47 Lig. acromioclaviculare

48 (Discus articularis)

49 Lig. coracoclaviculare

50 Lig. trapezoideum

51 Lig. conoideur

\section{ARTICULATIO STERNOCLAVICULARIS}

53 Capsula articularis

54 Discus articularis

55 Li.g. sternoclaviculare

56 ifig. costoclaviculare

57 Iig. interclaviculare

58 ARTICULATIO HURERI

59 Capsula articularis

60 Labrum glenoidale

61 Lig. coracohumerale

62 ARTICUAAIOECUBITI

63 Articulatio humeroulnaris

64 Articulatio humeroradialis

65 Articulatio radioulnaris proximalis

66 Capsuia articularis

67 Lig. coliaterale ulnare

$68 \mathrm{Iig}$. colleterale radiale

69 Lis. annulare radii 

1 Recessus sacciformis

2 Neribrana interossea antibrachii

3 Chorda obliqua

\section{ARIICULATIO RADIOULNARIS DISTALIS}

5 Capsula articuiaris

6 Discus articularis

7 Recessus sacciformis

\section{ARTICLLATIO MANUS}

9 Articulatio radiocarpea

10 Articulatio intercarpea

11 Capsula articularis

12 L亡g. racilocarpeun dorsale

13 Lig. radiocarpe un volare

14 Lig. carpi radiatum

15 Lig. collaterale carpi ulnare

16 Lig. collaterale carpi radiale

17 Ligg. intercarpea dorsaiia

18 Ligg. intercarpea volaria

19 Ligg. intercarpea interossea

\section{ARTICULATIO OSSIS PISIFORIIS}

21 Capsula articularis

22 Lig. pisohamatum

23 Lig. pisome tacarpeum

24 Canalis carpi

25 ARITCULAIIONES CARPOIETACARPEAE

26 Lapsulae articulares

27 Ligs. carpometacarpea dorsalia

28 Ligg. carpometacarpea volaria

\section{ARTICULAIIO CARPOIETACARPEA}

$$
\text { POLLICIS }
$$

30 Capsula azticularis

$3 I$ ARTICULATIONES INTERRETACARPEAE

32 Capsulse articulares

33 Ligg. basium [oss. metacarp] dorsalia

34 Ligg. basium [oss. metacarp volaria
35 Ligg. basium [oss. metacarp] interossea

36 Spatia interossea metacarpi

37 ARTICULATIONES METACARPOPHALANGEAE

38 Capsulae articulares

39 ìgg. collaterlia

40 Ligg. accessoria volaria

41 Ligg. capitulorum [oss. metacarpslium] transversa

42 ARTICULATIONES DIGITORUM HANUS

43 Capsulae articuiares

44 Ligg. collateralia

45 IIGG. CINGULI EXTRENITATIS INFERIORIS

46 Nembrana obturatoria

47 Canalis obturatorius

4 Lig. iliolumbale

$49 \mathrm{Lig}$. sacrotuberosum

50 Processus falciformis

51 Lig. sacrospinosum

52 Foramen ischiadicum majus

53 Foramen ischiadicum minus

54 ARTICULATIO SACROILIACA

55 Ligg. sacroiliaca anteriora

56 Ligg. sacroiliaca interossea

57 Lig. sacroiliacum posterior breve

58 Lig. sacroiliacum posterius Iongure

59 SYMPHYSIS OSSIUII PUBIS

60 Lig. pubicun superius

61 Lig. arcuatum pubis

62 Lamina fibrocartilaginea interpubica

63 ARTICULATIO COXAE

64 Capsula articularis

65 Labrum glenoidale

66 Lig. transversum acetabuli

67 Lig. teres femoris

68 Zona orbicularis

69 Lig. iliofermorale 

1 Lig. ischiocapsulare

2 Lig. pubocapsulare

\section{ARIICULATTO CENU}

4 Tapsula articularis

5 seniscus lateralis

o Veniscus medielis

7 Iig. transversum genu

8 L_Eg. cruciata genu

9 Ijig. cruciatum anterius

10 Lig. cruciatum posterius

11 Plica synovialis patellaris

12 Plicae alores

13 Lig. coliaterale fibulare

14 Iig. collaterale tibiale

15 Lif. popliteum obliquim

16 Lig. popliteum arcuatun

17 Retinaculum 1ig. arcuati

18 Lig. patellae

19 Retinaculum pateliae mediale

20 Retinaculum patellae laterale

\section{ARTICULATIO TIBIOFIBULARIS}

22 Capsula articularis

23 Ligg. capituli fibulae

2: Membrana interossea cruris

\section{SYNDESNOSIS TIBIORIBUIARIS}

26 Lig. malleoli lateralis anterius

27 Lig. malleoli lateralis pozterius

\section{ARTICULATIONES PEDIS}

\section{ARTICULATIO TAIOCRURAIIS}

30 Capsula articularis

31 Lig. del toideum

3\% Lig. tibionaviculare

33 Lig. calcane otibiale

34 Lig. talotibiale anterius

$35 \mathrm{Lig}$. talotibiale posterius

36 Lig. taloribulare anterius
37 Lig. talofibulare posterius

38 Lig. calcaneofibulare

\section{ARTICULAIIOIES INTERTARSEAF}

$\cdots$

40 ARTICULATIO TALOCALCANEONAVICULARIS 41

\section{ARTICULATIO TALOCALCANEA}

42 Capsula articularis

43 Lig. talocalcaneum laterale

44 Lig. talocalcaneum mediale

45 Lig. talocalcaneum anierius

46 Lig. talocalcaneum posterius

47 ARTICULATIO TARSI TRANSVERSA CHOPARTI

\section{ARTICULATIO TALONAVICULARIS}

49 Capsula articularis

50 ARTICUIATIO CALCANEOCUBOIDEA

51 Capeuia articularis

\section{ARTICULATIO CUNEONAVICULARIS}

53 IJIGG. TARSI INIEROSSEA

54 Li. . talocalcaneum interossoum

55 Lig. cuneocuboideum interosseum

56 Ligg. intercuneiformia interossee.

57 LIGG. TARSI DORSAIIA

58 Lig. talonaviculare dcrsale

59 Lig. cuneocuboideum dorsa.le

60 Lig. cuboidecnaviculare dorsale

61 Lig. bifurcatum

62 Pars calcaneonavicularis

63 Pars calcaneocuboidea

64 Lig. calcaneonaviculare dorsale

65 Ligg. navicularicuneiformia dorsalia

\section{LIGG. TARSI PLANTARIA}

67 Lig. plantare longum

68 Iigg. tarsi profunda

69 Lig. calcaneocuboideum plantare

70 Lig. calcaneonaviculare plantare 

I Fibrocartilago navicularis

2 Ligg. navicularicuneiformia plantaria

3 Lig. cuboideonaviculare plantare 4 Ligg. intercuneiformia plantaria 5 Lig. cuneccuboideun plantare

6 ARTICULATIONES TARSOIRTATARSEAF

7 Capsulae articulares

8 Ligg. tarsometatarsea dorsalis

9 Ligg. tarsometatarsea plantaria

$10 \mathrm{Ligg.} \mathrm{cuneometatarsea} \mathrm{interossea}$

11 ARTICULATIONES INTERIMTATARSEAE 12 Cai:sulae articulares
13 Ligg. bazium [oss. metatars] interossea

14 Ligg. Dasium [oss. metatars.] dorsalia

15 Iigg. basium [oss. metatars.] planteria

16 Spatia interossea metatarsi

17 ARIIEUAMIONES METATARSOPHALANGEAE

18 Capsulae articulares

19 Ligg. collateralia

20 Ligg. nccsoorin Flantarie

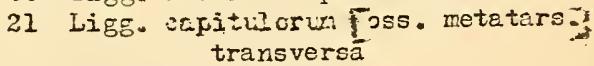

22 ARTICULATIONES DIGITORUN PEDIS 23 Capsulae articulares

24 Ligg. collateralia 

1 MYOLOGIA

2 insculus

3 Caput

4 Venter

5 Musculus fusiformis

6 Musculus unipennatus

7 lísculus bipennatus

8 isusculus sphincter

9 NuscuIus orbicularis

10 Nusculus articularis

11 Musculus skeleti

12 Muscuius cutaneus

13 Tendo
33 Aponourosis

34. Perimysium

35 Fascia

36 Fascia superficialis

37 Inscriptio tendinea

38 Arcus tendineus

39 Ligamentum vaginale

40 Vagina fibrosa tendinis

41 Vagina mucosa tendinis

42 irochlea muscularis

43 Bursa mucosa
15 H. trapezius

16 (M. transversus nuchae)

17 M. latissimus dorsi

18 H. Thomboideus major

19 M. rhomboideus minor

$20 \mathrm{M}$. levator scapulae

21 M. serratus posterior inferior

22 u. serratus posterior superior

23 M. splenius cervicis

24 M. splenius capitis

25 M. sacrospinalis

$26 \mathrm{M}$. iliocostalis

27 M. iliocostalis lumborum

$28 \mathrm{M}$. iliocostalis dorsi

20 M. iliocostalis cervicis

30 M. Iongissimus

$31 \mathrm{M}$. Iongissimus dorsi

32 M. Iongissinus cervicis
44 Ii. Iongissimus capitis

45 i. spinalis

46 ii. spinalis dorsi

$47 \mathrm{M}$. spinalis cervicis

48 M. spinalis capitis

49 M. semispinalis

50 H. semispinalis dorsi

51 if. semispinalis cervicis

52 M. semispinalis capitis

53 H. multifidus

$54 \mathrm{Mm}$. rotatores

55 Mm. rotatores longi

55 Min rotatores breves

$57 \mathrm{Mm}$. interspinales

$58 \mathrm{lim}$. intertransversarii

$59 \mathrm{~lm}$. intertransversarii laterales

$60 \mathrm{Mm}$. intertransversarii mediales

61 No. intertransversarii anteriores

$62 \mathrm{Wm}$. intertransversarii posteriores

63 H. rectus capitis posterior major 

I Nectus capitis posterior minor

2 W. rectus capitis lateralis

$3 \mathrm{M}$. obliquus capitis superior

4 3. obliquus capitis inferior

5 Fascia lumbodorsalis

6 Fascia nuchae

\section{MUSCULI CAPITIS}

8 N. epicranius

9 9 l. frontais

10 in. occipitalis

II M. procerus

12 M. Nasalis

13 Pars transversa

14 Pars alaris

M. depressor septi

M. orbicularis oculi

17 Pars palpebralis

18 Pars orbitalis

19 Pars lacrimalis Horneri]

M. auricularis anterior

i. auricularis superior

M. auricularis posterior

i. orbicularis oris

M. triangularis

(ii. transversus menti)

M. risorius

M. zygomaticus

M. quadratus labii superioris

29 Caput zygomaticum

30 Caput infraorbitale

31. Caput angulare

M. quadratus labii inferioris

i. caninus

14. buccinator

ilen. incisivi labii superioris

inn. incisivi lábii inferioris

M. mentalis

i. masseter

M. temporalis

ii. pterygoideus externus
41 M. pterygoideus internus

42 Galea aponeurotica

43 Fascia buccopharyngea

44 Fascia parotideomasseterica

45 Fascia temporalis

\section{MUSCULI OSS. HYOIDEI}

47 M. di ğstricus $^{2}$

48 Venter anterior

49 Venter posterior

$50 \mathrm{M}$. stylohyoideus

51 M. mylohyoideus

$52 \mathrm{M}$, genoihyoideus

\section{MUSCULI COLLI}

54 Platysina

55 W. sternocleidomastoideus

56 ii. sternohyoideus

57 H. omohyoideus

58 Venter superior

59 Venter inferior

$60 N$. sternothyreoideus

61 Ni. thyreohyoideus

62 (M. levator glandulae thyreoideae)

63 M. longus colli

64 M. longus capitis

$65 \mathrm{Ni}$. rectus capitis anterior

$66 \mathrm{Mi}$. scalenus anterior

67 M. scalenus medius

68 M. scalenus posterior

69 (M. scalenus minimus)

70 Fascia colli.

71 Fascia praevertebralis

\section{MUSCULI IHORACIS}

73 (M. vternalis)

74 M. pectoralis ma jor

75 Pars clavicularis

76 Pars sternocostalis

77 Pars abdominalis

$78 \mathrm{M}$. pectoralis minor

79 i. subclavius 

1 in. serratus anterior

$2 \mathrm{lim}$. levatores costarum

i3 $\mathrm{lin}$. levatores sostarum longi

$24 \mathrm{im}$. If evtores costarum breves

$5 \mathrm{lim}$. intercostales externi

$6 \mathrm{~km}$. intercostales interni

7 iim. subcostales

8 Li. transversus thoracis

9 Diaphragma

10 Pars lumbalis

11 Crus mediale

12 Crus intermedium

13 Crus laterale

14 Pars costalis

15 Pars sterralis

1: iatus aorticus

17 Hiatus oesophageus

18 Centrum tendineum

19 Foramen venae cavae

20 Arcus lumbocostalis medialis [Halleri]

2] Arcus lumbocostalis lateralis [Halleri]

22 Fascia pectoralis

23 Fascia coracoclavicularia

\section{MUSCULI ABDOININIS}

25 i. rectus abdominis

26 Falx aponeurotica inguinalis

27 in. pyramidalis

28 ii. obliquus externus abdominis

$29 \mathrm{ii}$. obliquus internus abdominis

30 i. cremaster

31 11. transversus abdominis

32 i. quadratus lumborum

33 Annulus umbilicelis $x$

34 Linea alba

35 Adrciniculum lineae albae

36 Inscriptiones tendineae

37 Lig. suspensorium penis $s$. clitoridis

38 Lig. fundiforme penis

39 Vagina $\mathrm{m}$. recti abcominis

40 Linea semicircularis [Douglasi]
41 Lig. inguinale [Pouparti

42 Lig. lacunare Gimbernati

43 Lig. inguinale reflexum [Collesi]

44 Annulus inguinalis subcutaneus

45 Crus superius

46 Crus inferius

47 Fibrae intercrurales

48 Trigonum Iumbale [Petiti]

49 Linea semilunaris [Spigeli]

50 Fascia transversalis

51 Canalis inguinalis

52 Annulus inguinal is abdominal is

53 Lig. interfoveolare [Hessel bachi]

54 Plica epigastrica

55 Fovea inguinalis lateralis

56 Fovea inguinalis medialis

57 Fovea supravesicalis

59 in. coccygeus

60 is. sacrococcygeus anterior

61 in. sacrococcygeus posterior

62 IUUSCULI EXTRENITATIS SUPERIORIS

$63 \mathrm{M}$. deltoideus

64 in. supraspinatus

65 ij. infraspinatus

$66 \mathrm{M}$. teres minor

67 in. teres major

$68 \mathrm{M}$. subscapularis

69 M. biceps $r=z$ chii

70 Caput longum

71 Vagina mucosa intertubercularis

72 Caput breve

73 Lacertus fibrosus

74 M. coracobrachialis

75 H. brachialis

76 H. triceps brachii

77 Caput longum

78 Caput laterale

79 Caput medials 

1 i. anconaeus

2 (If. epitrochleoanconaeus)

3 M. pronator teres 4 Caput humerale 5 Caput ulnare

6 M. flexor carpi radialis

7 E. palraris longus

$8 \mathrm{k}$. flexor sarpo u. naris

9 Caput numerale

10 Caput uInare

11 H. flexor digitorum sublimis

12 Caput huinerale

13 Caput radiale

$14 \mathbb{M}$. flexor digitorum proiundus

15 in. fiexor pollicis longus

16 M. proriator quadratus

17 M. branchioradialis

18 ih. extensor carpi radialis longus

19 in. extensor carpi radialis brevis

20 in. extensor digitorum comunis

21 Juncturae tendinum

22 i. extensor digiti quinti proprius

23 if extensor carpi ulnaris

24 is. supinator

25 N. abductor pollicis longus

$26 M$. extensor pollicis brevis

27 i. extensor pollicis longus

28 if. extensor indicis proprius

29 i. palmaris brevis

30 i. abductor pollicis brevis

31 i. flexor pollicis brevis

32 ir. opponens pollicis

33 if. adductor pollicis

34 in. abductor digiti quinti
42 Fascia supraspinata

43 Fascia infraspinata

44 Fascia brachii

45 Septim intermusculare [inmeri] mediale

46 Septum intermusculare [humeri] laterale

47 Sulcus bicipitalis medialis

48 Sulcus bicipitalis lateralis

49 Fascia antibrachii

50 Fascia dorsalis manus

51 Lig. carpi dorsale

52 dpsecroüis palmaris

53 Fasciculi transversi

54 Lig. carpi transversum

55 Lig. carpi volare

56 Chiasma tendinum

57 Vinculum tendinum

58 Vaginae musosae

59 Ligg. vaginalia digitorum manus

60 Ligg. annularia digitorum manus

$61 \mathrm{Ligg.} \mathrm{cruciata} \mathrm{digitorum} \mathrm{manus}$

63

64

65

66

67

68

69

70

71

72

73

74

75

76

77

78

79

\section{MUSCULI EXTREMITATIS INFERIORIS}

N. ilioposs

W. iliacus

i.. psoas rajor

ii. paoas minor

i. glutaeus maximus

M. glutaeus medius

M. glutaeus minimus

if. tens or fasciao latae

3. pirif ormis

i. obturator internus

ii. gemellus superior

i. gemellus inferior

3. quadratus femoris

11. sartorius

i. quadriceps femoris

ii. rectus femoris

ii. vastus lateralis 

1 II. vastus internedius 2 li. vastus redialis

3 in. articularis genu

4 ํ.. nestineus

5 i.. edductor longus

6 M. gracilis

7 1.. adductor brevis

8 ni. adjuctor nasnus

9 if. adductor minimus

10 i. obturator externus

11 if. bicisps femoris

\section{I2 Japut longum}

13 Ceput breve

14 is. semitendinosus

15 M. seninembranosus

16 tibialis anterior

17 M. extensor digitorun longus

18 M. percnaeus teriius

19 M. extensor hallucis longus

$20 \mathrm{M}$. peronaeus longlis

21 i. peronaeus brevis

22 M. triceps surae

23 H. gastrocnemius

$$
24 \text { Caput laterale }
$$

\section{M. soleus}

27 Arcus terineus m solei

28 Tendo calcaneus [Achillis]

29 if. plantaris

30 if. popliteus

31 H. tibialis posterior

32 2.. flexor digitorum longus

$33 \mathrm{M}$. flexor hallucis longus

34. in. extensor hallucis brevis

35 i. extensor cigitorum brevis

36

37

38

ii. abductor hallucis

ii. flexor hallucis brevis

ii. adductor hallucis

39 Caput obliquim

40 Caput transversum

41 is. abductor digiti quinti

42 li. flexor digiti quinti brevis

43 ii. opponens digiti quinti
44 M. flexor digitorum brevis

45 in. quadratus plantae

46 im. lumbricales

$47 \mathrm{Mm}$. interossei dorsales

$48 \mathrm{~N} / \mathrm{m}$. irterossei plantares

49 Fascia lata

50 Tractus iliotibialis [Maissiati

51 Septum intermusculare femoris]

52 Septum intermusculare [femoris] mediale

53 Canalis adductorius Eunteri)

54 Hiatus tendineus [adductorius]

55 Fascia iliaca

56 Fascia iliopectinea

57 Lacuna musculorum

58 Lacuna vasorum

59 Trigonum ferorale [Fossa Ecarpae major]

60 Fossa iliopectinea

61 Fascia pectinea

62 Canalis femoralis

E3 Annulus femoralis

64 Septirn femorale Cloqueti

65 Fossa ovalis

66 largo falciformis

67 Cornu superius

68 Cornu inferius

69 Fascia cribrosa

70 Fascia cruris

71 Septum intermusculare anterius

\section{fibulare}

72 Septum intermusculare posterius

fibulare

73 Lig. transversum cruris

74 Lig. laciniatum

75 ing. cruciatum cruris

76 Retinaculum mm. peronaeorum sup.

77 Retinaculum mi. peronaeorum inferius 

1 Fascia dorsalis pedis

2 Aponeurosis plantaris

3 Fasciculi transversi

aponeurosis plantaris
4 Vaginae mucosae

5 Ligg. annularia

6 Ligg. vaginalia

7 Ligg. cruciata

8 B URSAE ET VAGI II E II U OSAE

\& Bursa mucosa subcutanea

10 Bursa mucosa suomuscliaris

11 Bursa mucosa subfacialis

14 3. musculi trochlearis

15 B. . il. tensoris veli palatini

15 B. subcutanea praementalis

17 B. subcutarea prominentiae laryngeae

18 B. In. sternohyoidei

$19 \mathrm{BB} . m$. thyre ohyoidei

20 B. subcutanea sacralis

31 B. coccygea

22 B. subcutanea acromialis

23 B. subacromialis

24 B. subdel toidea

25 B. In. Corec jtrachialis

3E B. . infraspinati

27 B. in. subscapularis

28 B. n. teretis joris

20 B. m. latissini dorsi

30 B. subcutanea olecrani

31 B. intratendinea olecrani

32 B. subtendinea olecrani

33

B. subcutarea epicondyli

34 B. subcutanea epicondyli [humeri] IEC dialis

35 B. bicpitoradialis

36 B. cubitalis interossea
12 Bursa mucosa subtendinea

13 Vagina mucosa tendinis

37 Vagina tendinum mm. abductoris longi ot extensoris brevis pollicis

38 Vagina tendinum mo extensorum carpi radialium

39 Vagina tendinis $m$. extensoris pollicis longi

40 Vagina tendisum ma. extensoris digitorum comrunis et extensoris indicis

41 Vagina tendinis $m$. extensoris digiti minimu

42 Vagina tendinis $\pi$. extensori carpi vilnaris

43 3. m. extensoris carpi radialis brevis

44 Bursae subcutaneae metacarpophalangea dorsales

45 Bursae subcutaneae digitorum dorsales

46 B. m. flexoris carpi ulnaris

47 B. $m$. flexoris carpi radialis

48 Vagina tendinum. flexorum communium

49 Vag. tendinis m. flexoris pollicis longi

50 Bursae intermetacarpophalangeae

51 Vaginae tendinum digitales

52 B. trochanterica subcutanea

53 B. trochanterica m. glutaei maximi

54 B. troch. m. gluetei medii anterior 

1 B. troch. m. glutaei medii posterior B. troch. m. glutaei minimi

B. I. piriformis

B. m. obturatoris interni

Bursae glutaeofemorales

B. ischiadica m. glutaei raximi

B. I. recti femoris

B. iliopectinea

B. iliaca subtendinea

B. m. pectinei

B. m. bicipitis femoris superior

B. praepatellaris subcutanea

B. praepatellaris subfascialis

B. praepatellaris subtendinea

B. suprapatellaris

B. infrapatellaris subcutanea

B. infrapateilaris profunda

B. subcutanea tuberositatis tibiae

B. m. sartorii propria

B. anserina

B. m. bicipitis femoris inferior

B. m. poplitei

B. bicipitogastrocenemialis

B. m. gastrocnemii lateralis
25 B. m. gastrocnemii medialis

26 B. m. semimembranosi

27 B. subcutanea malleoli lateralis

28 B. subcutanea malleoli medialis

29 Vag. tendinis m. tibialis anterioris

30 Vag. tendinis $\mathrm{ml}$ extensoris hallucis longi

31 Vaginae tendinum m. extensoris digitorum pedis longi

32 Vaginae tendinum m. flexoris digitorum pedis longi

33 Vag. tendinis $\mathrm{m}$. tibialis posterioris

34 Vag. tendinis $\mathrm{m}$. flexoris hallucis longi

35 Yag. tendinum mm. peronaeorum communis

36 Bursa sinus tarsi

37 B. subtendinea $\mathrm{m}$. tibialis anterioris

38 B. subtendinea $m$. tibialis posterioris

39 B. subcutanea calcanea

40 B. tendinis calcanei [Achillis]

41 Vag. tendinis m. peronaei longi plantaris

42 Burase intermetatarsophalangeae

43 Bursae mm. Iumbricalium pedis

44 Vaginae tendinum digitales pedis 



\section{SPLANCHIOLOCIA}

2 Tunica albuginea

3 Tunica fibrosa

4 Tunica adventitia

5 Tunica mucosa

6 Lamina propria mucosae

7 Lamina muscularis mucosae

8 Tela submucosa

9 Plice mucosa

10 Sucus

11 Tunica muscularis

12 Tunica serosa

13 Tela suiserosa

14 Plica serosa

27 A P P A RA T US

28 CAVUI ORIS

29 Bucca

30 Corpus adiposum buccae

31 Vestibulum oris

32 Cavum oris proprium

33 Rima oris

34 Labia oris

35 Labium superius

36 Labium inferius

37 Commissura labiorum

38 Angulus oris

39 Pqlatum
15. is ganchtum serosum

16. Serum

17 Epithelium

18 Endothelium

19 Organon parenchymatosum 20 Parenchyma

21 Stroma

22 Glandula

23 Lobus

24 Lobul us

25 Glandula mucosa

26 Inusculus viscerum

DIGESTORIUS

40 Palatum durum

41 Palatum molle

42 Raphe palati

43 Tunica mucosa oris

44 Frenulurn labii superioris

45 Frenulu: labii inferioris

46 Gingiva

47 Caruncula sublingualis

48 Plica sublingualis

49 Plicae palatinae transversae

50 Papilla incisiva 



I Glandulae oris
2 Gl. labiales
3 Gl. buccales
4 GI. molares
5 Gl. palatinae
6 Gl. Iinguales
7 Gl. Iingualis anterior [Blantini Nuhni]
8 GI. sublingualis
9 Ductus sublingualis major
10 Ductus sublinguales minores
11 Gl. submaxillaris
12 Ductus submaxillaris [Whartoni]
13 Gl. parotis
15 Gl. parotis accessori
16 Ductus parotideus [Stenonis]
17 Saliva

18 Dentes

Corona dentis 20 Tubercula fcoronae dentis

Collum dentis

22 Radix Radices dentis

23

Apex radicis dentis

Facies masticatoria

Facies labialis buccalis

Facies lingualis

Facies contactus

28 Facies medialis ) dentium incisivo-

29 Facies lateralis rum et caninorum

30 Facies anterior dentium praemola-

31 Facies posterior rium et molarium

32 Cavum dentis

33 Pulpa dentis

34 Papilla dentis $x$

35 Canalis radicis dentis

36 Foramen apicis dentis

37 Substantia eburnea

38 Substantia adamantina

39 Substantia ossea

40 Câraliculi dentales

41 Spatia interglobularia

42 Prismata adamantina

43 Cuticula dentis

44 Periosteum alveolare

45 Arcus dentalis superior

46 Arcus dentalis inferior

47 Dentes irrisivi

48 Dentes canini

49 Dentes praemolares

50 Entes molares

51 Dens serotinus

52 Dentes permanentes

53 Dentes decidui

55

56

57

58

\section{0}

\section{6}

\section{2}

$$
63
$$

64

\section{5}

66

67

68

69

70 Papillae foliatae

71 Sulcus medianus linguae

72 Sulcus terminalis

73 Foramen caecum linguae (Morgagnii)

7 (Ductus lingualis)

75 Ductus thyreoglossus $x$

76 Tonsilla linguelis

77 Folliculi linguales

78 Septum Iinguae 

1 Musculi l ingua

2 M. genioglossus

3 M. hju bilossus

4 ii. chondroglossus

5 ii. styiogiessus

6 in. Iongitudinalis superior

7 M. longitudinalis irferior

8 M. transversus linguae

$\rightarrow$ M. verticalis linguae

10 Fauces

11 Isthmus faucium

12 Veluin palatinum

I3 Uvula palatina

14 Arcus palatini

15 frcus glossopalatinus

16 Arcus pharyngopalatinus

17 Plica salpingopalatina

18 Tonsilla palatira

19 Fossulae tonsillares

20 Sinus tonsillaris

21 Plica trianguleris

22 Fossa supratonsillaris

23 Nusculi palati et faucium

24 M. levator veli palatini

25 M. tensor veli palatini

26 M. uvulae

27 M. glossopalatinus

28 M. pharyngopalatinus

30 Cavum pharyngis

31 Fornix pharyngis

32 Pars nasalis

33 Pars oralis

34 Pars laryngea

35 Ostium pharyngeum tubae

36 Labium anterius

37 Labium posterius

38 Torus tubarius

39 Plica salpingopharyngea

4.) Recessus pharyngeus [Rosenmuelleri]
41 (Bursa pharyagea)

42 Recessus piriformis

43 in. stylopharynge us

44 Fascia pharyngobasilaris

45 Tunica mucosa

$46 \mathrm{Gl}$. pharyngeae

47 Tonsilla pharyngea

48 Fossulae tonsillares

49 Tela submucosa

50 Tunica muscularis pharyngis

51 Raphe pharyngis

52 Raphe pterygomandibularis

53 Th. constrictor pharyngis superior

54 M. pterygopharyngeus

55 M. buccopharyngeus

56 in. mylopharyngeus

57 M. glossopharyngeus

58 ih. salpingopharyngeus

59 H. ecnetriata? phangis medius

$60 \mathrm{M}$. chondropharynge us

61 if. ceratopharyngeus

62 i. constrictor pharyngis inferior

63 i. thyroopheryngeus

64 in. cricopharyngeus

\section{TUBUS DIGESTORIUS}

67 Pars cervicalis

66 Oesorhagus

68 Pars thoracalis

69 Pars abdominalis

70 Tunica adventitia

71 Tunica muscularis

72 M. bronchooesophage us

73 M. pleurooesophageus

74 Tela submucosa

75 Tunica mucosa

76 Lam. muscularis mucosae

77 Gl. oesophageae

$78 \frac{\text { Ventriculus }}{\text { Gaster }}$

79 Paries anterior

80 Paries posterior 

1 Curvatura ventriculi major

2 Curvatura ventriculi minor

3 Cerdia

\% rundis ventriculi

5 Curpus ventriculi

e Pylorus

") Pars carciaca

3 Pars pylorica

9 (Antrum cardiacum)

Io Antrum pyloricum

II Tunica serosa

12 Tunica rascularis

13 Stratum Iongitudinale

14 Ligg. pylori

15 Straturi circliare

16 M. sphincter priori

17 Fibrae obliçuae

18 Valvula pylori

19 Tela sybmucosa

20 Tunica muscosa

21 Lam. muscularis mucosae

22 Areae gastricae

23 Plicae villosae

24 Foveolae gastricae

25 Glandulae gastricae [propriae]

26 Glanduiae pyloricae

27 Noduli lymphatici gastrici

28 Succus gastricus

\section{Intestinum tunue}

30 Tunica serosa

31 Tunica muscularis

32 Stratum longi tudinale

33 Stratun circulare

34. Tela submucosa

35 Tunica mucosa

36 Lam. muscularis mucosae

37 Plicae circulares [Kerkringi]

38 Villi intestinales

39 GI. intestinales [ijieberkuehni]

40 Noduli lymphatici solitarii

41 Noduli lymphatici aggregati [Peyeri]
42 Chymus

43 Chylus

44 Sucus entericus

45 i u o d e n u I

46 Pars uperior

47 Pars descendens

48 Pais inferior

49 Pars horizontalis [inferior]

50 Pars ascendens

51 Flexura duodeni siperior

52 Flexura duodeni inferior

53 Flexura duodenojejunalis

$54 M$. suspensorius ducdeni

55 Plica Iongitudinalis duoderni.

56 Papilla duodeni Sentcrinj

58 Intestin $\mathrm{s}$ in $t$ e ri $u$ me s e nteriale.

59 Intestinum jejunum

60 Intestinum ileum

\section{Intestinum crassum}

62 I I t e stin u m c a e c u I I

63 Valvula col:

64 I.vium superius

65 Labium inferius

56 Frenula val rulae coli

67 Processus vermiformis

68 (Valvula processus vermiformis)

69 Noduli aggregati processus vermifor* mis

70 c $010 \mathrm{n}$

71 Colon ascendens

72 Flexura coli dextra

73 Colon transversum

74 Flexura coli sinistra

75 Colon descenders

76 Colon sigmoideum

77 Plicee senjlunares $201 i$

78 Haustra coli

79 Tunica serosa

80 Appendices epip?cicae

81 Tunica muscularis

82 Taenias coli 

1 Taenia mesocoiica

2 Taenia mentais

3 Taenia libera

4 TeIs submucosa

5 Tunica mucosa

6 Lam. muscularis mucosae

$\bar{i} \mathrm{Gl}$. intestinales ieberkuehni

3 Noduli lymphatici solitarii

\section{Intestinum recturn}

10 Flexura sacraitis

11 Flexura perineais

12 Ampulla recti

13 Tunica musculeriæ

14 $\mathrm{H}$. sphincter ani internus

15 M. rectococcygeus

16 Tela submucosa

17 Tunica mucosa

18 Lam. m. nucosae [intestirales [ieberkuehni]

20 Noduli lymphatici

21 Plicae transversales recti

22 pars a n $I$ is recti

23 Columnee rectales Horgagnii

26 Sinus rectales

25 Annulus haemorrhoidalis

\section{PANCRHAS}

27 Caput pancreatis

27 Caput pancreatis
28 Processus uncinatus Pancreas
(Winslowi]

29 Iñcisura pancreatis

30 Corpus pancreatis

31 Facies anterior

32 Facies posterior

33 Facies irferior

34 ilargo superior

35 Niargo anterior

36 Nargo posterior

37 Tuber omentale

38 Cauda pancreatis

39 Ductus pancreaticus firsung:
40 Ductus pancreaticus accessorius Santorini

41 (Pencreas accessorium)

42 Succus pancreaticus

\section{HEPAR}

44 Facies cuper ior

45 Facies posterior

46 Facies inferior

47 Liargo anterior

48 Incisura umbilicalis

49 Fossae sagittales dextrae

50 Fossa vesicae felleae

51 Fossa venae cavae

52 Fossa sagittalis sinistra

53 Fossa venae umbilicalis

54 Fossa ductus venosi

55 Tunica serosa

56 Iig. teres hepatis

57 Lig. venosum Aranti]

58 Porta hepatis

59 Lobus hepatis dexter

60 Lobus quadratus

61 Lobus caudatus Spigelii]

62 Processus papillaris

63 Processus caudatus

64 Lobus hepatis sinister

65 (Appendix fibrosa hepatis)

66 Impressio cardiaca

67 Tuber omentale

68 Impressio oesophagea

69 Impressio gastrica

70 Impressio duodenalis

71 Inpressio colica

72 Impressio renalis

73 Impressio suprarenalis

74 Lobuli hepatis

76 Rami arteriosi interlo ulares

77 Venae interlobulares

78 Venae centrales 

1 Ductus biliferi

2 Ductus interlobulares

3 Ductus nepatious

4 Vasa abe rantia hepatis

5 Fe? Bilis

6 Vesica fellea

7 Fun

8 Corpus vesicae felleae

9 Conlun vesicae felleae

10 Ducius eysticus

il Tuisica serosa vesicae felleae

I2 Tunica muscularis vesicae felleae

I3 Tunica mucosa vesicae felleae

14 Plicae tun micusae $v$ felleae

15 Valvula spiralin Heisteri]

16 Ductue chuiedochus

17 Gl. mucosae biliosae
18 LIEN

19 Facies diaphragmaiica

20 Facias renaiis

21 Facies gastrica

22 Extretaitas superior

23 Extrenitiss inferior

24 Nargo posterioj

25 Harro anterior

26 Hizus lienis

27 Tunica serose

28 Tunica aituginea

29 Trabeculae itenis

29 Trabeculae Iienis

30 Puipa lienis

31 Rami lienales [arteriae lienalis] 32 Penicilli

33 Kodvii lumphatici lienales Lialpighii

34 (Lien eccessorzus)

\section{3ミ APPARAIUS RESPIRATORIUS}

$37 \quad$ Nares

38 Choenae

39 Septum nasi

40 Septum carílaginetin

41 Septum treabranaceuri

42 Vestibulum nasi

43 Limen nasi

44 Sulcus olfactorius

45 (Concha nasalis suprera [Santoriny])

40 Concha nasalis superior

47 Concina nasalis media

48 Concha nasalis inferior

49 Lezbrana mucosa nasi

50 Plexus cavernosi concharum

51 Agger nasi

52 Recessus sphenoethmoidalis

53 Reatus nasi

54. Weatus nasi superior

55 lieatus nasi medius
50 Airium meatus medii

57 lizatus nasi intertor

58 lieetus nasi coramuis

59 Weatü mopharyngeus

60 Regio resuiratoria

61 Regio olíacioria

$62 \mathrm{Cl}$. OIfactoriae

63 Sinus paranasales

64 Sinus waxillaris [Highmori]

65 Sinus sphenoidalis

66: Sinus frortalis

67 Cellulae etimoidales

68 Bulla ethroj.ctais

69 Infundibuium ethmoidaze

70 Hiaius semiluraris

71 Gl. nasales

72 MASUS EXTERNUS

73 Basis nasi

74 Padix nasi 

1 Dorsum nasi

2. Mergyo nasi

Ape: nasi

îla nasi

Septum mobile nasi

Eartilagines a $\mathrm{g}$ a $i$

Cortilaso septi nasi

8 Processus sphenoidalis septi cartilaginei

9 Cartilago nasi leteralis

10 Carilago alaris najor

11 Crus meliaie

12 Crus Iacera'e

Cartilagines alares minores

Cartilagines sesamoideae nasi

orgenoi vomerorasale Jacobsonil

varilago voneronasalis [Jacobsoni]

(Ductus incisivus)

\section{LARYNX}

Prominentia Iaryngea

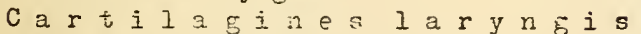
Cartilago thyreoidea

22 Lamina [extra et sinistra]

23 Incisura thyreoidea superior

24 Incisura thyreoidea inferior

25 Tuberculum thyreoideum superius

26 Tuberculum thyreoideum inferius

27 (iinea oblioua)

28 Cornu superius

29 Cornu inferius

30 (Foramen thyreoideun)

31 Lig. hyothyreoideum laterale

Cartilago triticea

Lig. njothyreoideum nedium

liembrana hyothyreoidea

Cartilago cricoiciea

36 Arcus cartilaginis cricoideae]

Lamina [cartilaginis criccideae]

Facies articularis arytaenoidea

Facies articularis tnyreoidea
40 Articulatio cricothyreoidea

41 Capsula articularis cricothyreoidea

42 ligg. ceratocrico dea lateralia

43 Lig. cerctocricoideum anterius

44 Ligg. ceratocricoided posteriora

45 Lig. cricothyreoideum [medium]

46 Lig. cricotracheale

47 Cartilago arytaenoidea

48 Facies articularis

49 Basis cartilaginis

50 Crista arcuata arytąnoideae)

51 Colliculus

52 Fovea oblonga

53 Fovea triangularis

54 Apex [cartilaginis arytaenoideae

55 Processus vocalis

56 Processis muscularis

57 Cartilago corniculata [Santorini]

58 Synchondrosis arycorniculata

59 Articulatio cricoarytaenoidea

60 Lig. cricopharyngeum

$61 \mathrm{Lig}$. corniculopharyngeum

$62 \mathrm{~L}=\mathrm{g}$. vestriculare

$63 \mathrm{Lig}$. vocale

64 (Cartilago sesamoidea)

65 Capsula articularis cricoarytaenoidea

66 Lig. cricoarytaenoideum posterius

67 Epiglotis

68 Petiolus epiglottidis

69 Tuberculum epiglctticum

70 Cartilego epiglottica

71 Lig. thyreopiglotticum

72 Lig. hyoepiglotticum

73 Cartilago cuneiformis [Wrisbergi]

74 Tuberculum ctueiformis (Wrisbergi)

75 Tuberculum corniculatum Santorinis

76 Muscuji laryngis

77 M. aryepiglotsicus

78 M. cricothyreoideus

79 Paiss recta 

1 Pars obliqua

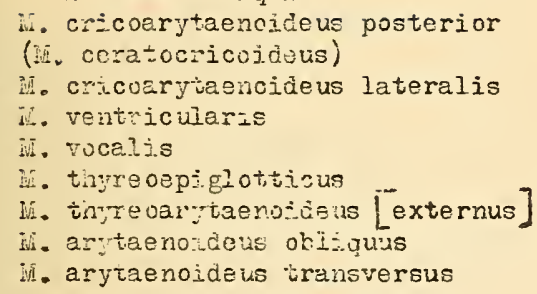

11 Cavm larmeis

12 Valiecula epiglottica.

13 Aditus laryngis

14 Vestibulum jaryngis

15 Rica vestibuli

16 Labiun vocale

17 Glottis

18 Rima glottidis

I9 Pars intermernbranacea

20 Pars intercurti.aginea

21 Ventriculus laryngis [Ourgegnii]

22 Appendix ventuiculi laryngis

23 Tunice mucosa laryngis

24 Nembrana elastica la:yngis

25 Conus elesticus

25 Plica glosscepiglottica mediana

27 Plica glosscepiglottica lateralis

23 Plica aryevigtot:ica

22 Plica nerri laryngei

30 Plica ventricularis

31 Plica vocais

32 Nacula flava

33 Aditus glottidis inferior

34 Aditus glottidis superior

35 Incisura interarytaenoidea

36 Gl. laryngeae

37 Gl. laryngeae anteriores

$38 \mathrm{Gl}$. laryngeae mediae

39 G1. laryngeae postariores

40 Noduli lymphatici laryngei
41 TRACHEA ET BRONOHI

42 Cartilagines trachealcs

43 Ligg. annularia tiachealia

44 Paries menibrarece

45 Gl. trachea.es

46 Birurcatin tracheae

47 Bronchus [doyter et sinister]

48 Rami bronchiales

49 Ramus bronchialis eparterialis

50 Rami bronchiales hyparteriales

51 Tunica muscularis

52 Tela submucosa

53 Tunica mucosa

54 Gl. tracheales

55 Gl. bronchiales

\section{PULito}

57 Basis pulmonis

58 Apex pulmenis

59 Sulcus subclavius

60 Facies costalis

61 Facies mediestina? is

62 Facies diaphragmatica

63 Nar go anterior

C4 Margo inferinr

65 Hi.? us puimonis

66 Radix pulmonis

67 Incisura cajdiaca

68 Lobus superior

69 Lobus meciius

70 Lobus inferior

71 Incisura inte:lobaris

72 Lobuli pulisonum

73 Rami bronshiales

74 Bronchioj.

75 Bronchioli respizatorii

76 Ductuii aiveclares

77 AIveoli puexnonum

78 Lynohoglandulse bronchiales

79 Noduii iyrohatic: bronbiniales

80 Lymphoglandulae pulmoraies 

1 CAVUI THORACIS

2 Fascia encothoracica

3 C a v um ple ura e

4 Pleura

5 Cupula plourae

6 Pleura pulnonalis

7 Pleura parietalis

8 Pleura nerliastinalis

9 Laninee mediastinales

10 Pleura pericardiaca

11 Pleura costalis

12 Pleura diaphragnetica

13 Sinus plevrae

14 Sinus phrenicocostalis

15 Sinus costomediastinalis

16 Lig. pulmonale

17 Plicae adiposae

18 Villi pleurales

19 Septum mediastinale
20 Cavum mediastinale anterius

21 Covum mediastinale posterius

22 GL. THYREOIDEA

23 Isthmus gl. thyreoideae

21 (Lobus pyramidalis)

25 Lobus [dexter et sinister]

26 Lobuli gl. thyreoideae

27 Stroma gl. thyreoideae

28 (GI. thyreoideae accessoriae)

29 (Gl. thyreoidea accessoria suprehyoidea)

\section{GLOHRE CAROTICUM}

\section{THYMUS}

32 Lobus [dexter et sinister]

33 Tractus centralis

34 Loouli tinymi

\section{A P P A A T U U UROGENITALIS}

36 ORGANA UROPOFTIC:

38 Nargo lateralis

39 Nargo medialis

40 Hilus renalis

41 Sinus renalis

42 Facies anterior

43 Facies posterior

44 Extremitas superior

45 Extremitas inferior

46 (Impressio muscularis)

47 (Impressio hepatica)

48 (Impressio gastrica)

49 Capsula adiposa

50 Tunica fibrosa

51 Tunica muscularis

52. Tubuli renales

53 Tubuli renales contorti
54 Tubuli renales recti

55 Substantia corticalis

56 Substantia medullaris

57 Lobi renales

58 Pyramides renales [Malpighii]

59 Basis pyramidis

60 Papillae renales

51 Area cribrosa

62 Foramina papillaria

63 Columnae renales [Bertini]

64 Lobuli corticales [Processus Ferreini]

66 Pars convoluta

67 Corpuscula renis [Malpighii]

68 Goreruli

69 Capusla glomeruli

70 P e I vis re $n$ a I is

71 Calyces renales 

1 Calyces renales majores

$\therefore$ Calyces renales minores

3 (il. pelvis renalis

\section{Arteriae renis}

$5 \mathrm{Aa}$. interlobares renis ss Arteriae arciformes

7 Arteriae interlobulares

8 Vas afferens

9 Vas efferens

1.) Rami cepsulares

11 Arteriolae rectae

12 Aa. nutriciae pelvis renalis

13 Vene renis

14 Vv. interlobores

15 Venae arciformes

16 Venae interlobulares

17 Venae interlobulares

18 Venae stellatae

\section{UREIER}

20 Pars abdominalis

21 Pars pelvina

22 Tunica adventitia

23 Tunica muscularis

24 Stratum exterrum

25 Stratum medium

26 Stratum internum

27 Tunica mucosa

28 (1. mucose.e ureteris

29 VISICA URINARIA

30 Vertex vesicae

31 Corpus vesicae

32 Fundus vesicae

33 Lig. umbilicale nedium

34 Urachus $x$

35 Tunica serosa

36 Tunica inuscularis

37 Stratura externuxa
38 Stratum medium

39 Stratum internum

40 Li. pubovesicalis

41 li. rectovesicalis

42 Tela submucosa

43 Tunica mucosa

$44 \mathrm{Gl}$. vesicales

45 Noduli lymphatici vesicales

46 Trigonum vesicae [Lieutaudi]

47 Uvuala vesicae

48 Plica ureterica

49 Orificium ureteris

50 Orificium urethrae internum

51 Annulus urethralis

52 GLANDULA SUPRIRENALIS

53 Substantia corticalis

54 Substantia medul].aris

55 Hilus gl. suprarenalis

56 Facies anterior

57 Facies posterior

58 Fasis gl. suprarenalis

59 Apex suprarenalis [gl. dextrae]

60 Margo superior

61 largo medialis

62 Vena centralis

63 (G1. suprarenales accessoriae)

64 ORGANA GENITALIA

65 ORGANA GPNITALIA VIRILIA

67 Extremitas superior

68 Extremitas inferior

69 Facies lateralis

70 Facies medialis

71 Margo anterior

72 Margo posterior

73 Tunica albuginea

74 Nediastinum testi [Corpus Highmori]

75 Septula testis 

1 Lobuli testis

2 Parenchyma testis

3 Tubuli seminiferi contorti

4 Tubuli seniniferi recti

5 Lurica propria

iete testis [Halleri]

Ductuli efferentes testis

Sperma [Semen]

E p i di

Caput epididymids

Corpus epidicymidis

Cauáa epididymidis

Lobuli eojdidynidis

Ductus e-ididymidis

Ductuli aberrantes

(Ductulus aberrans superior)

Appendices testis

18 Appendix testis [Morgagnii]

19 (Appenilx epididymis)

20 P a r a d i y mis

21. Ductus deferens

22 Amoul la ductus deferentis 23 Jiverticlile arpuliae

24. Tunica adventitia

25 Tunica muscuiaris
26 Siratum externum
27 Siratum medium
28 Stratum internum

29 Tunica mucosa

30 Ductus ejaculatorius

31 Vesicula seminalis

32 Corpus vesiculae seminalis

33 Turica adventitia

$3 \pm$ Tunica muscularis

35 Tlinica mucosa

36 Ductus excretorius

37 Puniculus spermaticus et tunicae iestis et funiculi sprematici

38 (Rudimentun processus vaginalis)
39 Tunica vaginalis propria testis

40 Lamina parietalis

41 Lamina visceralis

42 Lig. epididyridis superius

43 Lig. epididymidis inferius

44 Sinus epididymidis

45 Tunica vaginalis comunis testis et funiculi spermatici

46 M. cremaster

47 Fascia cremasterica [Cooperi]

48 Descensus testis $x$

49 Gubernaculum testis [Hunteri]x

\section{Prostata}

51 Basis prostatae

52 Apex prostatae

53 Facies anterior

54 Facies posterior

55 Lobus [dexter et sinister]

56 Isthmus prostatae

57 (Lobus redius)

58 Corpus glandulare

60 Succus prostaticus

61 Mi. prostaticus

\section{Glanduia bulbourethralis [Cowperi] \\ 63 Corpus gl. bulbourethralis \\ 64 Ductus excretorius}

65 PARTES GENITALES EXTERNAE

67 Radix penis

\section{PENIS}

68 Corpus penis

69 Crus penis

70 Dorsum penis

71 Facies urethralis

72 Glans penis

73 Corona glandis

74 Septur glancis

75 Collum glandis 

1 Preeputium

2 Frenulum praeputii

3 Raphe penis

4 Conpus cevernosum penis

Copus cavernosum urethrae

Evivus urethrae

7 Hemisphaeria bulbi urethrae

$S$ Septum bulbi urethrae

g. Tuice albuginea corperum cavernoso:un

10 Sevtun penis

11. Irabeculae corporum cavernosorum

I2 Cavemae corporum cavernosorum

13 hruriae helicinae

is Ve.ze cavernosae

15. Lig. suspensoriuni penis

16 Fascia penis

17 G1. praeputiales

18 Smegna praeputi‡

\section{URETHRA VIFILIS}

$20 \mathrm{P} a \mathrm{r}$ s p o s t a t ica

21 Crista uretinralis

22 Colliculus seminalis

23 Utriculus prostaticus

24 P a $r$ me m b a n c e a

25 Pars c a vernosa

26 Flossa navicularis urethrae

For gegnit

27 (Valvula foseae navicularis)

28 Orificium urethrae externum

29 Iacunae urethraies [norgagnii]

$30 \mathrm{GI}$. urethrales [LIttrei]

\section{SCROTUI}

32 Raphe scroti

33 Septum scroti

34 Tunica dartos

35 ORGANA GENTTALIA IULIEBRIA

36 Ovarium

37 Hilus ovarii

38 Facies medialis 3j. Factas lo varalis

(f) ierzo like:

41 hiargo mesovaricus

42. Extremitas tubaria

43 Extremitas uterina

44 Stroma ovarii

45 Folliculi oophori primarii

46 Folliculi cophori vesiculosi [Graafi]

47 Thece fclliculi

48 Tunica externa

49 Tunica interna

50 Liquor folliculi

51 Stratua granulosum

52 Cumulus cophorus

53 Oviliur

54 Corpus Iuteum

55 Corpus alyicans

56 Lig. ovarii proprium

57 Tuba uterina [Falloppii]

58 ostium abdominale tubae uterinae

59 Infundibulum tubae uterinae

60 Fimbriae tubae

61 rimbria ovarica

62 Anpulla tubae uterinae

53 Isthrus tubae utarinae

64 Pars uterina

65 Ostium uterinum tubae

65 Tunica serosa

67 Tunica adventitia

68 Tunica c musculuris

69 Stratur longitudinale

70 Stratum circulare

71 Tela submucosa

72 Tunica muscosa

73 Plicae tubariae

74 Piicae ampullares

75 Plicae isthmicae

76 Uterus

77 Corpus uteri 

1 Fundus uteri

2 Margo lateralis

3 Facies vesicalis

4 Facies intestinalis

5 Cevur uteri

5 Orificium internum uteri

7 Cervix uteri

3 Portio suprevaginalis fervicis

9 Portio vagiralis [cervicis]

10 Orificiun externuri uteri

II Labiurs anterius

12 Labiun posterius

13 Canalis cervicis literi

14 Plicae palnatae

$15 \mathrm{GI}$. cervicales [uteri]

Is

17

18

19

20

ini

iunica sercsa [Perimetrium]

Tunica ruscularis

Tunica muscularis cervicis

Tunica mucosa

$21 \mathrm{Gl}$. uterina

22 il. rectouterinus

23 Lig. teres uteri

24 (Processus vaginalis peritonaei)

\section{Vagina}

25 Fornix vaginae

27 Paries anterior

28 Paries posterior

29 Hymen femininus

30 Carunculae hymenales

31 Tunica muscularis

32 Tunica mucosa

33 Noduli Iymphatici vaginales

34 Rugae vaginales

35 Columae rugarum

35 Columna rugarum posterior

37 Columna rugarum anterior

38 Carina urethralis [vagina]

39 Epoophoron

40 Ductus epoophori longitudinalis [Gartneri]
41 Ductuli transversi

Appendices vesiculosi [Morgagnii]

43 Paroophoron

\section{PARTES GENITALES EXTERNAE}

45 Pudendum muliebre

46 Labium majus pudendi

47 Commissura labiorum anterior

48 Commissura labiorum posterior

49 Frenul um labiorum pudendi

50 Rima pudendi
51 Fossa navicularis [vestibuli vaginae]

52 Labium minus pudendi

53 Vestibulum vaginae

54 Bulbus vestibuli

55 Gl. sebaceae

$56 \mathrm{Gl}$. vestibulares minores

57 Orificiur vaginae

58 G1. vestibularis major [Bartholini]

60 Crus clitoridis

61 Cornus clitoridis

62 Glsna elitoridio

63 Frorialum clitoridis

64 Praeputium clisoridis

65 Smegma clitoridis

66 Corpus cavernosum clitoridis

6? Septure corporum cavernosorum

68 Fascia clitoridis

69 Lig. suspensorium vlitoridis

70 URETHRA IUULIEBRIS

71 Orificium urethrae externum

72 Corpus spongiosum urethrae

73 Turica muscularis

74 Stratum circulare

75 Stratim longitudinale

76 Tunica submucosa

77 Tunica mucosa 


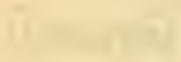

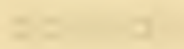

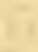

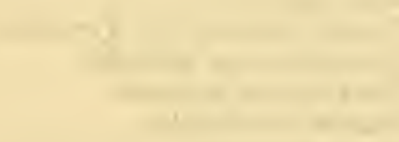

$+2$

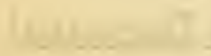

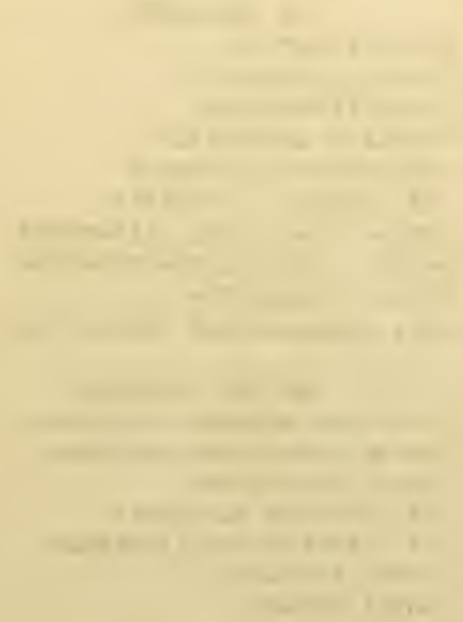




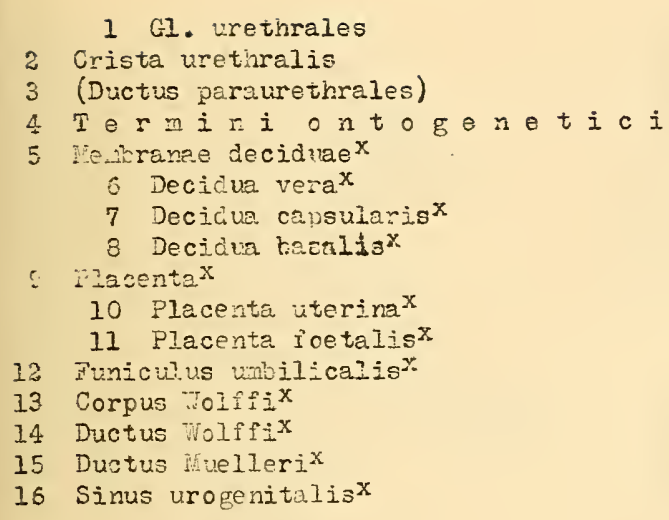

\section{PERIITU:}

18 Paphe perinei

19 Nus culi perinei

20 D i p h r a ma pelvis

21 M. levator ani

22 Arcus tendine us : Ievatoris ani

23 M. coccygeus [vide p.25]

$24 \mathrm{M}$. sphincter ani externus $25 \mathrm{Lig}$. anococcygeur

26 Fascia pelvis

27 Fascia endopelvina

28 Fascia diaphragmatis pelvis superior

29 Arcus tendineus fasciae pelvis

30 Lig. puboprostaticum

31 I,ig. puboprostaticura

$$
\text { [pubovesicale] medium }
$$

pubovesicale laterale

32 Fascia dicphragratis pelvis inverior

33 Di a phragma

$$
\text { urogenita } 1 \text { e }
$$

34 is. transversus perinei profundus

$35 \mathrm{M}$. sphincter urethrae membranaceae

36 Fascia diaphragmatis urogenitalis superior

37 Fascia diaphragmatis urogenitalis inferior
38 Lig. transversum pelvis

33 Fascia prostatae

40 Fascia obturatoria

41 Fossa ischiorectalis

42 H. transversus perinei superficialis

43 ii. ischiocave nosus

44 i. bulbocavernosus

45 Fascia superficialis perinei

\section{FERITONAELR}

47 Tunica serosa

48 Tela subserosa

49 Peritonaeuri parietale

50 Peritonaeun viscerale

51 Cavum peritonaei

52 ivesenterium commune $x$

53 inesenterium

54 Racix mesenterii

56 Mesocolon

57 Resocclon transversum

58 liesocolon ascendens

59 Miesoccion descendens

60 Resocclon sigmoideum

61 Niesorectura

62 inesenteriolum processus vermif ormis

63 Nesogastrium $x$

64. Omentum minus

65 Lig. hepatogastricum

6ô Lig. hepatoduodenale

67 (Lig. hepatocolicum)

68 Lig. gastrolienale

69 Lig. gastrocolicum

70 Cmentum majus

71 Bursa omentalis

72 Vestibulum bursae omentalis

73 Recessus superior omentalis

74 Recessus inferior omentalis

75 Recessus lienalis

76 Plica gastropancreatica
77 Foramen ipiploicum [Winslowi] 

1 Lig. phrenicocolicum

2 Lig. phrenicolienale

3 Li

4 Lis. coronariura hepatis

5 Lis. triangulare dextrum

6 Lï. trianguiare sinistrum

7 Lig. hepatorenale

8 (isig. duodenorenale)

9 Recessus duodenoje junalis

10 Plica ducdeno; $\theta$ junelis

Il (Plica duodenomesocoiica)

12 Recessus intersigmoideus

13 Recessus iliccaecalis superior

14 Recessus iliocaecallis inferior

15 Plica iliocrecolis

16 Fossa caecalis

17 Recessus retrocaecalis

18 Plica caecalis

19 Recessus paracolici

20 (Fossa iliacosubfascialis)
21 (Recessus phrenicohepatici)

22 Plica unbilicalis media

23 Plica umbilicalis lateralis

24 Plica epigastrica

25 Plica pubovesica?.is

26 Plica vesicalis transversa

27 Mesorchium

28 Frocessus vaginalis peritonaeix

29 Lig. latur uteri

30 Mesometriun

31 Mesosalpinx

32 Nesovarium

33 Bursa ovarica

34 Lig. suspensoriun ovarii

35 Plica rectouterina Douglasi]

3 Excavatio rectouterina [Cavum Douglasi]

37 Excavatio vesicouterina

38 ixcavatio rectovesicalis

39 Spatiun rotroperitonaeale 



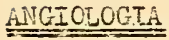

2 Vas collateralj

3 Vas anestomoticum.

4 Ranis communicars

5 Flexus vescuiosus

6 Rete vascuíosuis

7 Rete uirabile

8 Arteria

9 Anteriola

10 Vena

11 Viena cutanea

12 Vena comitans

13 Venula

14 Plexus venosus

15 Rate ve:osum

16 Sinus [verosus]
17 Emissarium

18 Corpus cavernosum

19 Vas capjilare

20 Vas Iymphaticum

21 Plexus lymphaticus

22 Lymphoglandula

23 Nodulus lympinaticus

24 Cisterna

26 Tunica media

27 Tunica intima

28 Vasa vesorum

29 Vagina vasorum

30 Sanguis

31 Eympha

32 COR

33 Basis cordis

34 Facies sternocostalis

35 Facies diaphragnatica

36 Apex corcis

37 Incisura [apicis] cordis

38 Sulcus longitucinalis a.aterior

39 Sulcus longitucinalis posterior

40 Sulcus coronarius

41 Perisardium

42 Liquor pericardi亡

43 Ligg. sterncpericardiaca

44 Sinus transversus pericardii

45 EDicardium

46 Hrocardium

47 Endocardium

48 Ventriculus cordis
49 Septum ventricul orum

50 Septum musculare ventricul orum

51 Septum membranaceum ventriculorven

52 Atrium cordis

53 Auricula cordis

54 Septum atriorum

55 Pars membranacea septi atriorum

56 Ostium veroslim

57 Ostium arteriosum

58 Trabeculae carneae

59 Vortex cordis

$60 \mathrm{hm}$. papiilares

61 Chordae tendineae

62 Trigona fibrosa

63 Annuli fibrosi 



\section{ATRIUM IEXTRUM}

22 Mr. pectineti

3 Snlicus terminalis atrii dexti

4 Crjsta terminajis

5 Sinus venarum cavarum?

6 Limbus iossae ovalis Vieussenii]

7 Auricula dextre

8 Tuberculum intervenosun [Joweri]

9 Valvula venee cavae inferioris. Eustachili

10 Fossa ovalis

11 Valvula sinus coronarii Theresii

12 Foraraina venarym minimarum Thebesii

13 VEHTRICULUS DEXTER

14 Valvula trieuspidalis

15 Cuspis anterior

16 Cuspis pisterior

17 Cuspis medialis

18 Crista sliperaventricularis

19 Corius arteriosus
20 Valvulae semilunares a. pulmonalis

21 Valvuia semilumaris anterior

22 Valvula semiluneris deztra

23 Valvuia semilumaris sinistra

24 Noduli valvi:lariun sersiluna:'ilus

25 Lunulae valvularun semilunarirm

\section{ATRIUH SINISTRUN}

27 Auricuia siristra

28 Valvuia forminis ovalis

29 VENTEICULUS SINTSTER

30 Valvula bicuspidalis mitralis

32 Cuspis posteriur

33 Valvulae semilunares aortae

34 Valvula semi? uriaris posterior

35 Valvula seniluniris dextra

36 Valvula semilunaris sinistra

37 Noduli val vularum sernilunarium

38 Arantil

38 Lunuiae valvulerum semilunarium

39 ARTERIAE

41 Ramu A. PULIKGNAIIS

42 Remus sinister

43 Ductus arteriosus [Botalli] $x$

44. Iigamentum arteriosum

\section{ACSTA}

46 Aorta ascendens

47 Bilbus aortae

48 Sinus aortae [Vaisalvae]

49 Arcus aortae

50 Isthmus aortae

51 Aorta descendens

52 A. ccronaria [cordis] dextra

53 Ramus descendens posterłor
54 A. coronaria [cordis] sinistra

55 Ramus circunîligus

56 Ramus descenāens arterior

$$
57 \text { A. ANONYMA }
$$

58 (A. thyreoidea ima)

\section{A. CAROTIS COMMUNIS \\ $60 \mathrm{~A}$. CAROTIS EXTERNA}

61 A. thyreojiea superior

62 Ramus hyoirious

63 Ramus sternocleidomastoideus

64 A. laryngea superior

65 Ramus circothyreoideus 

1 Aa. ciliares anteriores

$2 \mathrm{Aa}$. conjunctivales anteriores

3 Aa. conjunctivales posteriorca

4 Aa. episclerales

5 A. supraorbitalis

6 A. ethnoidalis posterior

7 A. ethmoidalis anterior

8 A. meningea anterior

9 Aa. palpebrales mediales

10 Arcus tareus superior

11 Arcus tarseus inferior

12 A. Frontalis

13 A. dorsalis nasi

\section{Aa. cerebri}

15 A. communicans posterior

16. A. choriojdea

17 A. cerebri anterior

18 A. communicans anterior

19 A. cerebri media

20 A. SUBCLAVIA

21 A. vertebralis

22 Rami spinales

23 A. spinalis posterior

24 A. spinalis anterior

25 Ramus meningeus

26 A. cerebelli inferior posterior

\section{A. basilaris}

28 A. cerebelli inferior anterior

29 A. auditiva interna

30 Rami ad pontem

$31 A_{4}$ cerebelli superior

32 A cerebri posterior

33 Circulus arteriosus [Willisi]

34 A. mamaria interna

$35 \mathrm{Aa}$. mediastinales anteriores

36 Aa. thymicae
37 Rani bronchiales

38 A. pericardiacophrenica

39 Rami stermales

40 Rami perfurantes

41 Rami marmarii

42 Rami musculares

43 Rami cutanei

44 (Ramus costalis lateralis)

45 Rami intercostales

45 h. muscul ophrenica

47 A. epigastrica superior

48 Truncus thyreccervicalis 49 A. thyreoidea inferior

50 A. laryngea inferior

51 Rami pharyngei

52 Rami oesophagei

53 Raxi tracheales

54. Rami glandulares

55 A. cervicalis ascendens

56 Rami spinales

57 Rami musculares

58 Ramus profundus

\section{A. cervicalis superficialis}

60 A. transversa scapulae

61 Ramus acrumialis

62 Truncus cestocervicalis

63 A. intercostalis suprena

64 Remi dorsales

65 Rami spinales

66 A. cervicalis profunda

68 Ramus ascendens

67 A. transversa colli

69 Ramus descendens

70 A. AXIILARIS

71 Rami subscapulares 

1 A. thoracalis sunrema

2 A. thoracoacromialis

3 Pamus acroritis

4 Rot,e acromiale

5 Rainus deitiodeus

6 Rami pectorales

7 A. thoracilis lateralis

8 Rami manacii externi

9 A suhs:apularis

10 A. thoraconos selis

Il A. circumilexa scapulae

12 A. circumflexa humeri anterior

13 A. circumflexa humeri posterior

14 BRACHTIITS

15 A. profunca brachii

$16 \mathrm{Aa}$. nutritiae humeri

17 R. deltoideus

18 A. collateralis nedia

19 A. collateralis radialis

20 A. collateralis ulnaris superior

21 A. collaterelis ulnaris inferior

\section{A. RADIALIS}

23 A. recurrens radielis

24 Rami musculares

25 Ramus carpeus volaris

26 Ramus volaris superficialis

27 Ramus carpeus dorsalis

28 Rete carpi dorsaie

29 Aa. metacarpeae dorsales

30 Aa. digitales dorsales

31 A. princeps pollicis

32 A. volaris indicis radialis

33 Arcus volaris profundus

$34 \mathrm{Aa}$. metacarpeae volares

35 Rami perforantes
36 A. UINAPIS

$37 \mathrm{Aa}$. recurrentes uinares

38 Rete articware cubiti

39 Ar intorossea cominis

40 A. interossea dorsalis

41 A. interossea recurrens

42 A. interossea volaris

43 A. mediana.

44 Rami muşculares

\$5 Ramus carpeus dorsalis

$4 \hat{~ R a m u s ~ c a r p e l i s ~ v o ! e r i s ~}$

47 Ramus volaris prof uncius

48 Arcus volaris superficialis

49 Aa. digitales volares communes

50 Aa. digitales volares propriae

51 AORTA THORLCAIIS

$52 \mathrm{R}$ a mi vis cera $l$ es

$53 \mathrm{Aa}$. brorchiales

54 Aa. oesophageae

55 Ẽami perzcaräizci

5t $\mathrm{Rami}$ a a r i e ta 1 e s

57 Pami mediastinales

$58 \mathrm{Aa}$. phronicae superiores

59 Aa intercostalos

60 Rami postieriores

61 Famus spiralis

62 Rami musculares

63 Eamus cutaneus medialis

64 Ramus cutanevs lateralis

65 Rami anceriores

66 Kami musculares

67 Rami cutanei laterales pectoralas et abcominales

68 Ramus posterio= 

1 Ramus anterior

2 Rami rammarii laterales

3 Rami cutanei anteriores fpectorales et abdominaled

4 Rarni mamarii mediales

5 AORTA AEDORINALIS

6 R a mi pai e t a l es

7 A. phrenica inferior

8 Rami suprarenales superiores

Iv Razus dorezlis

9 Aa. Iumbales

Il Rarrus spinalis

13 A. Iumbais ima

12 A. sacralis media

14. Glonus coccygeum

$15 R$ ami viscera 1 es

\section{A. coelieca}

17 A. gastrica $\leq i n i s t r a$

18 Rami oesophagei

19 A. he patic a

20 A. gastrica dextra

21 A. hepatica propria

22 Ramus dexter

23 A. cystica

24 Ramus sinister

25 A. gastroduodenalis

26 A. pancreaticoduoden. superior

27 Rami pancrea úci

28 Rani duodenales

29 A. gastroepiploica dextra

30 Rami epiploici

31 A. I i e n a 1 s

32 Rami pancreatici

33 A. gastroepiploica sinistra

34 ia. gastricae kreves.

35 Rami lienales
36 A. mesenterica superior

37 Aa. intestinales

38 A. pancreaticoduodenalis

inferior

39 Aa. jejunales

40 Aa. ileae

41 A. ileocolica

42 A. appendicularis

43 h. colica dextra

44 A. colica nedia

: $45 \bar{A}$-meserivica inferior

46 A. colica sinistra

$47 \mathrm{Aa}$. sigmoideas

48 A. naemorthoidalis superior

49 A. suprarenalis media

50 A. renalis

51 A. ouprarenalis inferior

52 A. Spermatica interna

53 A. testicularis

54 A. ovarica

55 A. ILIACA CORMIUNIS

56 A. HYPOGASTRICA

57 R a mi $p a=i$ e t a 1 es

\section{A. iliolumbalis}

59 Ramus lumbalis

66 Ramus spinalis

61 Ramus iliacus

62 A. sacralis lateralis

63 Rami spinales

64 A. obturatoria

65 Ramus pubicus

66 Ramus anterior

67 Ramus posterior

68 A. acetabuli 



\section{A. Elutaea superior \\ 2 Ramus superior \\ 3 Romus inferior}

4 A. glutaea inforior

5 A. comitans n. ischiadic

- Ramiviscerales

7 A. umbilicalis

8. Aa. vesicales superiores

9 [Ligamentum unilicale laterale]

10 A. vesicalis inierior

11. A. deferentialis

12 A. uterina

13 A. vaginalis

14 Ramus overii

15 Ramus tribarius

\section{A. haemorrhoidalis modia}

17 A. pudenda interna

18 A. haemorrhoidalis inferior

19 A. perinei

$20 \mathrm{Aa}$. scrotales posteriores

21 Aa. labiales posteriores

22 A. penis

23 A. urethralis

24 A. bulbi urethras

25 A. bulbi vestibuli [vaginae]

25 A. profunda penis

27 A. dorsalis penis

28 A. clitoridis

29 A. profunda clitoridis

30 A. dorsalis clitoridis

31 A. ILIACA EXIERIA

32 A. epigastrica inferior

33 Ramus pubicus

34 Ramus obturatarius
35 A. spermatica externa

36 A. lig teretis uteri

37 A. circumflexa ilium profunde

38 A. FEIORALIS

39 A. epigastrica superficialis

40 A. circumflexa ilium superficialis

$41 \mathrm{~A}$. pudendae externae

42 Aa. scrotales anteriores

$43 \mathrm{Aa}$. labiales anteriores

44 Rarii inguinales

45 A. profunda femoris

46 A. circumflexa femoris medialis

47 Ramus superficialis

48 Ramus prof undus

49 Ramus acetabuli

50 A. circumflexa femoris lateralis

51 Ramus ascendens

52 Ramus descendens

53 A. perforans prima

54 A. nutritia femoris superior

55 A. perforans secunda

56 A. perforans tertia

57 A. nutritia femoris inferior

58 Rami musculares

59 A. $g \in n u$ s u $r$ e ma

60 Rami musculares

61 Ramus saphenus

62 Rami articulares

\section{A. POPLITHA}

64 A. genu superior lateralis

65 A. genu superior medialis

66 A. genu media

67 Aa. surales

68 A. genu inferior lateralis

69 A. genu inferior medialis

70 Rete articulare genu

71 Rete patellae 

I A. tibialis anterior

2 (A. recurrens tibialis posterior)

3 A. recurrens tibialis antericr

4 A. malleolaris anterior lateralis

5 A. malleolaris anterior medialis

6 Rete malleolare mediale

7 Rete malleolare laterale

8 A. dorsalis pedis

9 A. tarsea lateralis

$10 \mathrm{Aa}$. tarseae mediales

11 A: arcuata.

12 Foto lirvicie pudic

$13 \mathrm{Aa}$. metatarsede dorsales

$14 \mathrm{Aa}$. digitales dorsales

15 Ramus plantaris profundus

16 A.tibialis posterior

17 Ramus fibularis
18 A. peronaea

19 A. nutritia fibulae

20 Ramus perforans

21 Ramus communicans

22 A. malleolaris posterior lateralis

23 Rami calcanei laterales

24 A. nutritia tibiae

25 A. malleolaris posterior medialis

26 Rami calcanei mediales

27 Rete calcaneim

28 A. plantaris redialis

29 Rerilf Defunlus

30 Ramus superficialis

31 A. plantaris lateralis

32 Arcus piantaris

$33 \mathrm{Aa}$. metatarscae plentares

34 Rami per forantes

$35 \mathrm{Aa}$. digitales plantares

\section{VENAE PUJMONALES}

$38 \mathrm{Vv}$. pujmonales dextrae

$39 \mathrm{Vv}$. pulmonales sinistrae

\section{$40 \mathrm{VV}$. CORDIS}

41 Sinus coronarius

42 V. cordis magna

$43 \mathrm{~V}$. posterior ventriculi sinistri

44 V. obliqua atrii sinistri

[ivarshalli].

45 Lig. v. cavae sinistrae

46 V. cordis media

47 V. cordis parva

$48 \mathrm{Vv}$. cordis anteriores

$49 \mathrm{Vv}$. cordis minimae

50! IVENA CAVA SUPERIOR

51 VV. ANONYMAE DEXTRA ET SINISTRA

52 Vv. thyreoideae inferiores

$53 \mathrm{~V}$. thyreoidea ima
54 Plexus thyreoideus impar

$55 \mathrm{~V}$. laryngea inferior

$56 \mathrm{Vv}$. thymicae

$57 \mathrm{Vv}$, pericardiacae

$58 \mathrm{Vv}$. phrenicae superiores

$59 \mathrm{Vv}$. mediastinales anteriores

$60 \mathrm{Vv}$. bronchiales anteriores

$61 \mathrm{Vv}$. tracheales

62 Vv. cesuphageae

$63 \mathrm{~V}$. vertebralis

64 V. cervicalis profunda

$65 \mathrm{~V}$. rammaria interra

$66 \mathrm{Vv}$. subcutaneae abdominis

67 V. epigastríca superior

$68 \mathrm{~V}$. intercostalis supreme

$69 \mathrm{~V}$. JUGULARTS INTERNA

70 Bulbus venae jugularis superior

71 V. canaliculi cobhleas 

1 Bulbus v. jugularis inferior

2 Plexus pharyngeus

$3 \mathrm{Vv}$. pharyngeae

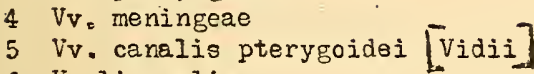

6 V. lingualis

7 Vv. dorsales linguae

8 V. sublingualis

9 V. comitans $n$. hypoglossi

10 (\% . thyreoideae superiores)

$11 \mathrm{~V}$. sternocleidonastoidea

$12 \mathrm{~V}$. laryngea superior

\section{Sinus durae matris}

14 Sinus transversus

15 Confluens siriuum

$16 \mathrm{Vv}$. auditivae internae

17 Sinus occipitalis

18 Plexus basilaris

19 Sinus sagittalis superior

20 Sinus sagittalis inferior

$2 I$ Sinus rectus

22 Sinus petrosus inferior

23 Sinus petrosus superior

24 Sinus cavernosus

25 Sinus intercavernosus anterior

26 Sinus intercavernosus posterior

27 Sinus circularis

28 Sinus sphenoparietalis

29 Venae diploicae

$30 \mathrm{~V}$. diploica froutalis

31 V. diploica temporalis anterior

$32 \mathrm{~V}$. diploica temporalis fposteior

$33 \mathrm{~V}$. diplocai occipitalis

34 Emissarium parietale

35 Emissarium mastoideum

36 Emssarium condylofideum

37 Traissarium occipitale

38 Rete canalis hypoglossi

39 Rete foraminis ovalis

40 Plexus venosus caroticus internus
41 Venae cerebri

$42 \mathrm{Vv}$. cerebri superiores

$43 \mathrm{~V}$. cerebri media

$44 \mathrm{Vv}$. cerebri inferiores

$45 \mathrm{Vv}$. cerebolli superinres

$46 \mathrm{Vv}$. cerebelli inferiores

$47 \mathrm{Vv}$. cerebri internae

$48 \mathrm{~V}$. cerebri magna [Galeni]

4.9 V. septi pellucidi

$50 \mathrm{~V}$. terminalis

51 V. vasal1s thosenthali

52 V. choriojde?

$53 \mathrm{~V}$. ophthalmomeningea
55

56

57

58

59

60

61

62

63

64

65

56

67

68
$54 \mathrm{~V}$ - cpinthalmica superior

V. nascfrontalis

$V$. etrmoidalis anterior

$V$. ethmoidalis posterior

V. lacrimalis

Vv. muscularea

$V v$. vorticosae

Vv. ciliares posteriores

Vv. ciliares anteriores

$v$. centralis retinae

Vv. episclerales

Vv. palpebrales

$V_{v}$. conjunctivales anteriores

Vv. conjunctivales posteriores

V. opinthalmica inferinr

\section{$69 \ddot{v}_{\circ}$ FACIALIS COWWINIS}

70 A. facialis anterior

11 V. angularis

72 V. frontales

$73 \mathrm{~V}$, supraorbitalis

74 Vv. Faipebrales superiores

$75 \mathrm{Vv}$. nasales externae

76 vv. palpebrales inferiores

77 V. labialis superior 

1 V. labialis inferior

Vv. masseterica

Vv. parotideae anteriores

V. palatina

$V$. subinentalis

$6 \mathrm{~V}$. facialis posterior

7 Vv. temporales superficiales

$8 V_{v}$. auriculares anteriores

\% Vw. parotideae posteriores

$10 \mathrm{Vv}$. articulares mandibulae

$11 V_{v}$. tympanicae

$12 V$. stylomastoidea

$13 \mathrm{~V}$. transversa faciei

$14 \mathrm{~V}$. temporalis media

15 Plexus pterygoideus

$16 \mathrm{vv}$. meningeae mediae

$117 \mathrm{Vv}$. temporales profundae

18 V. thyreoidea superior

19 V. JUGULARIS EXIERINA

$20 \mathrm{~V}$. occipitalis

$21 \mathrm{~V}$. auricularis posterior

$22 \mathrm{~V}$. jugularis anterior

23 Arcus venosus juguli

24 (V. mediana colli)

25 V. transversa scapulae

\section{V. SUBCLA IIA}

27 V. thoracoecrcmialis

$28 \mathrm{Vv}$. transversae colli

\section{$29 \mathrm{~V}$. AXILLARIS}

$30 \mathrm{~V}$. thoracalis lateralis

$31 \mathrm{Vv}$. costoaxillares

$32 \mathrm{Vv}$. thoracoepigastricae

33 Plexus venosus mamillae

34 Vv. irachiales

$35 \quad V_{v}$. radiales

$36 \mathrm{Vv}$. ulnares

37 V. cephalica

38 V. cephalica accessoria
39 V. basilise

$40 \quad V$. mediana cubiti

41 (V. nediane antibrachii)

42 (V. modiuna basilica)

43 (V. mediana cephaiica)

44 Rete venosum dorsale manus

$45 \mathrm{Vv}$. intercapitulares

46 Arcus volaris venosus superficialis

47 Arcus volaris venosus profundus

$48 \mathrm{Vv}$. Gigitales volares communes

$49 \mathrm{Vv}$. metacarpeae dorsales

$50 \mathrm{Vv}$. metacarpeae vclares

$51 \mathrm{~V} v$. digitales volares propriae

52 Arcus venosi digitales

\section{V. AZZCOS}

$54 \mathrm{~V}$. hemiazygos

$55 \mathrm{~V}$. hemiazygos accessoria

$53 \mathrm{Vvo}$ intercostales

57 Ramus dorsalis

58 Ranus soinalis

$59 \mathrm{VV}$. ces zphageae

60 Vv. brorchiales posteriores

$61 \mathrm{~V}$. lumbalis ascendens

62 Plexus venosi vertebraies externi

64 Plexus venosi vertebrales anteriores

65 Plexus venosi vertebrales posteriores

66 Plexus venosi vertebrales interni

67 Retia venosa vertebrarum

68 Sinus vertebrales longitudinales

$69 \mathrm{Vv}$. intervertebrales

70 Vv. spinales externae anteriores 

1 Vv. spinales externae posteriores

2. Vv. spinales internae

3 V. CAVA INFERIOR

4 Radicos parietales 5 v. phrenica inferior

$6 \mathrm{Vv}$. Iumbales

7 Radices iscerales $8 \mathrm{Vv}$. hepaticae

9 Vv. renales

$10 \mathrm{Vv}$. suprarenales

II $V$. spermatica

12 V. testicularis

13 v. ovarica

14 Plexus pampiniforrais

\section{VENA PORTAE}

$16 \mathrm{~V}$. coronaria ventriculi

$17 \mathrm{~V}$, mesenterica superior

$1818 \mathrm{Vv}$. intestinales

19 V. gastroepiploica dextra

$2 \theta$ Vv. pancreaticae

$2 I V$. ileocolica

$22 V_{v}$. colicae dextrae

$23 \mathrm{~V}$. colica media

$24 \mathrm{Vv}$. pancreaticoduodenales $25 \mathrm{Vv}$. duodenales

$26 \mathrm{~V}$. mesenterica inferior 27 V. colica sinistra

28 Vv. sigmoideae

$29 \mathrm{~V}$. haemorrhoidalis

$30 \mathrm{~V}$. lienalis superior

31 Vv. gastricae breves

32 V. gastroepiploica sinistra

$33 \mathrm{~V}$, cystica

34. Vena umbilicalis $x$

35 Ductus venosus [Arantii] $\mathrm{x}$

36 Vv. parumbilicales [Sappeyi]
37 VENA ILIACA COMHUNIS

38 V. sacralis media

39 V. HYPOSASTRICA

$40 \mathrm{Vv}$. glutaeae superiores

41 Vv. glutaeae inferiores

42 Vv. obturatoriae

43 Vv. sacrales laterales

$44 \mathrm{~V}$. iliolumbalis

45 Plexus ancralis r.itarfor

46 Plexus haemorrhoidalis

47 Plexus vesicalis

48 Plexus pudendalis

49 V. dorsalis penis

50 Vv. profundae penis

51 V. dorsalis clitoridis

52 Vv. profundae clitoridis

$53 \mathrm{Vv}$. uterinae

54 Plexus uterovaginalis

$55 \mathrm{~V}$. haemorrhoiłalis media

$56 \mathrm{Vv}$. haemorrhoidales inferiores

$57 \mathrm{Vv}$, scrotales posteriores

58 V. ILIACA EXTERNA

$59 \mathrm{~V}$. epigastrica inferior

$60 \mathrm{~V}$. circumflexa ilium profunda

61 V. femoralis

62 Vv. dorsales penis subcutaneae

63 Vv. scrotales anteriores

$64 \mathrm{Vv}$. pudendae externae

$65 \mathrm{~V}$. epigastrica superficialis

66 V. saphena magna

67 V. Ecphena accessoria

$68 \mathrm{~V}$. circumflexa ilium superficialis

69 Vv. circumflexae femoris mediales

70 Tv. circumflexae femoris laterales

$71 V_{v}$. comitantes

72 Vv. prof undae femoris

$73 \quad V_{v}$, perforantes 

$1 V$. saphena parva

$$
2 \text { V. femoropoplitea }
$$

$3 \mathrm{Vv}$. peronaeae

$4 \mathrm{Vv}$. popliteae

5 Vv. tibiales posteriores

$6 \mathrm{Vv}$. tibiales anteriores

7 Rete venosum dorsaie pedis

8 Arcus venosus dorsalis pedis
9 Vv. digitales comanes pedis

$10 \mathrm{Vv}$. metatarseae dorsales pedis

$11 \mathrm{Vv}$. intercapitulares

12 Rete venosum plantare

13 Arcus venosus plantaris

$14 \mathrm{Vv}$. metatarseae plantares

$15 \mathrm{Vv}$. digitales pedis dorsales

$26 \mathrm{Vv}$. digitales plantares

\section{SYSTEIA LYIPHAIICUI}

\section{VASA LMPHAIICA}

19 Vasa lymphatica superficialia

20 Vasa lymphatica profunda

21 Truncus jugularis

22 Truncus subclavius

23 Truncus bronchomediastinalis dexter

24 Ductus Iymphaticus dexter

\section{Ductus thoracicus}

26 Trunci Iurabales

27 Truncus intestiralis

28 Cisterna chyli

\section{Lymphoglandulae}

30 Vasa afferentia

31 Vasa efferentia

32 Substantia corticalis

33 Substantia medullaris

34 Hilus

35 Lymphoglandulae occipitales

\section{2}

43

44

45

46

47

48

49

50

51

52

53

54

55

56

57

58

59

60

61

62

63

64

65

66
Lymphoglandulae cervicales profundae superiores

" cervicales profundae inferiorea

linguales

axillares

* subscapulares

- pectorales

- epigastricae

- cubitales superficiales

- cubitales profundae

" tracheales

- bbonchialea

"intercostales

$n$ mediastinales posteriores

" mediastinales anteriores

"sternales

" iliacae

" lumbales

* coeliacae

" gastricae superiores

* gastricae inferiores

- hepaticae

" pancreaticolienales

* mesentericae

" mesocolicae

" hypogastricae 

1 Lymphoglanduche sacrales

2 "inguinaies

3 " subing virales superficiales

$4 \pi$ subinguirales prof unảae

5 " prpilteae

6 (Lyriphoglandula tibialis anterior)

7 PLEXUS LYMPHATICI

8 Plexus jugularis
9 Plexus axillaris

10 Plexus mamiarius

11 PJexus Irmbalis

12 Plexus aorticus

13 Piexus sacralis medius

14 Plexus hypogastricus

15 Plexus coeliacis

3.6 Plexus i?lacus externus

17 Plexus inguinaiis 

1 NEUROLOGIA

2 Nervus

3 Ganclion

4 Susstantia alba

5 Substantia grisea

6 Substantia gelatinosa

7 Taenia telarum

8 Ependyma ventriculorum

9 Sulcus limitans ventriculorum

10 Nuclei nervorum cerebraliun
11 Nuclei originis

12 Nuclei terminales

13 Ramus communicirss

14 Ranus anastomoticus

15 Ramus muscularis

16 Nervus cutaneus

17 Nervus articularis

18 Plexus nervorum spinalium

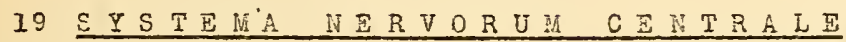

20 IEDULLA SPINALIS

21 Pars cervicalis

22 Intumescentia cervic ilis

23 Pars thoracalis

24 Pars lumbalis

25 Intumescentia I umbalis

26 Conus medullaris

27 Filum terminale

28 Ventriculus terminalis

29 Fissura nediana anterior

30 Sulcus medianus posterior

31 Sulcus lateralis anterior

32 Sulcus lateralis posterior

33 Sulcus intermedius posterior

34 (Salcus internedius anterior)

35 Funiculi medullae spinalis

36 Funiculus anterior

37 Funiculus lateralis

38 Funiculus posterior
39 Sectiones medullae spinalis

40 Canalis centra?is

41 Substantia grisea centralis

42 Commissura anterior alba

43 Commissura anterior grisea

44 Comnissura posterior

45 Columnae griseae

46 Columna anterior

47 Columna laterais

48 Columa posterior

49 Cervix columnae posterioris

50 Apex columnae posterioris

51 Substantia gelatinosa [Rolandi]

52 Nucleus dorsalis [stillingi, Clarkii]

53 Fromatio reticularis

54 Funiculus anterior

$55^{\circ}$ Fasciculus cerebrospinalis anterior [pyramidalis anterior] 

1 Fasciculus anterior proprius Flechsigi)

2 Funiculus lateralis

3 Fasciculus cerebrospinalis lateralis [pyramidalis

4 Fasciculus cerebellospinalis

5 Fasciculus anterolateralis superficialis [Gowers:]

6 Fasciculus lateralis proprius [Elechsigi]

7 Funiculus posterior

8 Fasciculus grecilis [Golli]

9 Fascioulus cuncotus [Burdachis?

10 ENCEPHAION $\therefore$ II R FO II B E IN C E P HALON

12 MYELENCEPHALON

13 il e d u I l a ob $1 \circ \mathrm{ng}$ a ta

14 Fissura mediana posterior

15 Fissura mediane anterior

16 Foramen caecum

17 Pyramis medullae oblongatae

18 Decussatio pyranidum

19 Sulcus lateralis anterior

20 Sulcus lateralis posterior

21 Oliva

22 Corpus restiforme

23 Funiculus lateralis

24 Funiculus cuneatus

25 Tubercullum cingreum

26 Funiculus gracilis 27 Clav?

28 Fibrae arcuatae externae

29 Sectiones redullae

30 Raphe oblongatre

31 Stratum nucleare

32 'Nucleus n: hypoğlossi

33 liucleus anbiguus

34 Nucleus alae cinereae

35 Tractus solitarius

3E Nucleus'tractus solitarii

37 Tractus spinalis n. trigemini

38 Nucleus tractus spinalis n. trigemini trigemini

39 Nucleus funiculi gracilis
40 ITucleus funiculi cunezti

4 Nuclei laterales

42 Nucleus olivaris inferior

43 Hilus nuclei olivaris

44 Mucleus olivaris accessorius medialis

45 Iucleus olivaris accessorius dorsaiis

46 Nuclei arcuati

47 Fibrae arcuatae internae

48 Substantia reticularis grisea

40 Substantia reticularis alba

50 Fasciculus longituainalis nedialis

51 Stratum interolivare lemnisci

53 Corpus restiforie

54 Fasciculi corporis restiformis

55 Fibrae cerebelloolivares

56 Fasciculi pyranidales

57 Fibree arcuatae externae

58 v e n t $r i c u l u s$ $q u a r t u s$

59 Fossa rhomboidea

so Pers inferior fossae rhomboid eac

61 [Calamus scriptorius]

62 Pars intermedia [fossa rhomboideae]

63 Recessus lateralis fossae rhomboideae

64 Pars superior fossae rhomboideae

65 Sulcus limitans fossae rhomboideae? 66 Fovea inferior 

1 Fovea superior

2 Trigonum n. hypoglossi

3 Striae medullares

4 Eminentia medialis

5 Colliculus facialis

6 Ala cinerea

7 Area acustica

8 Locus caeruleus

9 Tegmen ventriculi quarti

10 Velum medullare posterius

11 Taenia ventriculi quarti

12 Obex

13 Lamina chorioidea epithelialis

14 (Apertura medialis: ventriculi quarti)

15 Foramen Magendii])

16 (Apertüra lateralis ventriculi quarti)

17 Fastigium

\section{LIETEHCEPHALOK}

20 Sulcus basilaris $r$ o 1 i

21 Fasciculus obliquus [pontis]

22 (Fila lateralia pontis)

23 Brachium pontis

24 Sectiones pontis

25 P a r s dors a 1 is

26 Raphe $p \circ n t i s$

27 Nucleus $n$. abducentis

28 Nuclei motorii n. trigemini

29 Radix descendens [mesencephalica] n. trigemini

30 Tractus spinalis n. trigemini

31 Nucleus tractus spinalis $n$. trigemini

32 Nueleus n. facialis

33 Radix n. facialis

34 Pars prima

35 Genu internum

36 Pars secunda

37 Nuclei n. acustici

38 Nuclei $n$. cochlearis
39 Nuclei $n$. vestibularis

40 Nucleus olivaris superior

41 Nucleus lemnisci lateralis

42 Fasciculus longitudinalis medialis

43 Formatio reticularis

44 Corpus trapezoideum

45 Lemniscus

4646 Lemniscus medialis [sensitivus]

47 Leminiscus lateralis

[acusticus]

$48 \mathrm{Pars}$ basilaris $p \circ n t i s$

49 Fibrae pontis profundae

50 Fasciculi longitudinales

[pyramidales]

51 Nuclei pontis

52 Fibrae pontis superficiales

$53 \mathrm{C}$ e $\mathrm{r}$ e b e $\mathrm{l} \mathrm{l} \mathrm{u}$

54 Gyri cerebelli

55 Sulci cerebelli

56 Vallecula cerebelli

57 Incisura cerebelli anterior

58 Incisura cerebelli posterior

59 Silcus horizontalis cerebelli

60 Fissura transversa cerebelli

61 Vermis

62 Lingula cerebelli

63 Vincula lingulae cerebelli

64 Lobulus centralis

65 Monticulus

66 Culmen

67 Declive

68 Folium vermis

69 Tuber vermis

70 Pyramis [vermis]

71 Uvula [vermis]

72 Nodulus

$73 \mathrm{H} \in \mathrm{m} i \mathrm{~s} p \mathrm{~h}$ a e r i u cerebe $11 i$

74 Facies superior

75 Ala lobuli centralis

76 Lobulus quadrangularis

77 Pars anterior

78 Pars posterior 

1 Lobulus semilunaris superion:

2 Facies inferior

3 Lobulus semilunaris inferior

3 Lobulus grajiz

4 Lobulus biventer

5 Tonsilla cerebelli

6 Flocculus

7 (Flocculi secondarii)

8 Pedunculus flocculi

9 Niduc avis

11 Corpus meaullare

12 Laminae medullares

13 Arbor vitae

14 Substantia corticalis

15 [Lamina basalis]
16 [Stratum cinereum]
17 [Stratum gangliosum]
18 [Stratum granulosum]

19 Nucleus dentatus
20 Hilus nuclei dentati

21 Nucleus fastigii

22 Nucleus globosus

23 Nicleus emboliformis

24 Capsula nuclei dentati

25 Isthmus rhombencephali

26 Brachium confunctivum

27 Lemiscus

$$
\text { [cerebelli] }
$$

.23 . Leminisou Iaterilis

29 Lemniscus medialis

30 Trigonum lemnisci

31 Velum medullare anterius

32 Frenulum $v e l i$ medullaris anterioris

33 Sectiones isthmi

34 Ganglion interpedunculare

35 Hic leus $n$. trcchlearis
37 Facies convexa cerebri

38 Facies medialis cerebri

39 Basis cerebi $i$

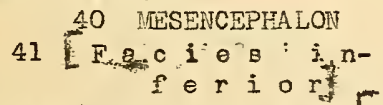

42 Fossa interpeduncularis [Tarini]

43 Recessus anterior

44 Recessus posterior

45 Substantia perforata posterior

$46 \mathrm{P}$ e d u n u l u s

$$
\text { o } \theta r e b r i
$$

47 Aquaeductus cerebri [Sylvii]

48 Sulcus lateralis

49 Sulcus n. oculomotorii
50 Sectiones pedunduli uerori

51 T e $\mathrm{g}$ e $\mathrm{n}$ i $\mathrm{u}$

52 Stratum griseum centrale

53 Formatio reticularis

54 Fasciculus longitudinalis medialis

55 Radix descendens n. trigenini

56 Hucleus radicis descendentis n. trigemini

57 Nucleus n. ovulomotorii

58 Nuciei tegmenti

59 inucleus ruber

60 Decussationes tegmentorum

61 Decussatio brachii conjunctivi

62 Lemniscus lateralis

63 Lemniscus medialis

$64 \mathrm{~s} u \mathrm{~b}$ s $t$ a n $t$ i a n i g r a

65 B a s is pedunculi 

cor p o r a

q $u$ a d $r$ i g e In i n a

2 Larina quadrigemina

3. Colliculus superior

4 Colliculus inferior

5 Brachium quadrigeminum superius

6. Brachium quadrigeminum inferius

7 Sectiones corporum quadrigeminorum

8 Stratum zonale

9 Stratum griseum colliculi superioris

10 ivucleus colliculi inferioris

Il Stratum album profundun

12 PROSENCEPHALON

13 Dienceptialon

$14 \nabla$ entriculus tertius

15 Aditus ad aouaeductum cerebri

16 Comissura posterior cerebri]

17 Foramen interventriculare [Monroi]

18 Sulcus hypothalamicus [Monroi]

19 Massa intermedia

20 Recessus opticus

21 Recessus infundibuli

22 Commissura anierior [cereori]

23 Recessus triangularis

\section{Hypothalamus}

25 Pars mamillaris

hy $\mathrm{p} \circ \mathrm{th}$ a $\mathrm{l}$ a $\mathrm{mi}$

26 Corpus mamillare

27 Pars optica

h y p ot ha la mi

28 Tuber cinereurn

29 Infundibulum

30 Hypophysis

31 Lobus enterior

32 Lobue posterior

33 Tractus opticus

34 Radix medialis

35 Radix lateralis

36 Chiasma opticum

37 Lamina terminalis
38 Sectiones hypothalari Nuclous hypothalamicus

Corpus. Luysi]

40 Pars grisea hypothalami

41 Commissura superior [Meynerti)

42 Commissura inferior [Guddeni]

43 Nuclei corporis mamillaris

44 Fasciculus thalamomamillaris 'Vicq' d'Azyri]

45 Fasciculi pedunculomamillares

46 Pars tegmentalis

47 Pars basilaris

48 Ansa pedincularis

49 Ansa lenticularis

50 Pedunculus thalami inferior

\section{Thalamencephalon}

52 T h a l a mus

53 Pulvinar

54 Tuberculum anterius thalami

55 Taenia thalami

56 Stria medullaris

57 Lamina chorioidea epithelialis

58 M e t a t h a l a m u s

59 Corpus geniculatum mediale

60 Corpus geniculatum laterale

61 E p i th a 1 a $\mathrm{mus}$

62 Corpus pineale

63 Recessus pirealis

64 Recessus suprapinealis

65 Habenula

66 Commissura habenularum

67 Trigonum habemulae

69

68 Sectiones thalamencephali Stratum zonale

70 Nucleus anterior thalami

71 Nucleus medialis thalami

72 Nucleus lateralis thalami

73 Laminae medullares thalami 

1 Nucleus corporis geniculati medialis

2 Nuclous corporis geniculati lateralis

3 iTucleus habenulae

4 Fasciculus retroflexus Meynerti]

5 Telencephalon

$\frac{6}{7}$ Hemisphaerium

8 Fissura longitudinalis cerebri

9 Fissura transversa cerebri

10 Gyri cerebri

11 Gyri profundi

12 Gyri transitivi

13 Sulci cerebri

14 Impressio petrosa

15 Fossa cerebri lateralis [Sylvii]

16 Fissura cerebri lateralis

[Sylvii]

I7 Ramus posterior

18 Ramus anterior ascendens

19 Ramus anterior horizontalis

20 L 0 bi e e b r i

21 I n s l a

22 Gyri insulae

23 iyrus longus insulae

24 Gri breves insulae

25 Sulcus circularis [Reili]

26 cnerculun

27 Pars frontalis

28 Pars parietalis

29 Pars temporalis

30 sulcus centralis [Rolandi]

31 rus centralis anterior

32 rus centralis posterior

33 Iso.b us fronta 1 is

34 Polus frontalis

35 Sulcus praecentralis

36 Gyrus frontalis superior

37 Sulvus Prontalis superior

38 Gyrug frontalis medius

39 Pars superior
40 Pars inferior

41 Sulcus frontalis inferior

42 Gyrus frontalis inferior

43 Pars opercularis

44 Pars triangularis

45 Pars orbitalis

46 Gyrus rectus

47 Sulcus olfactorius

48 Gyri orbitales

49 Sulci orbitales

50 i o b u s t em pora $l$ is

51 Polus temporalis

52 Sulci temporales transversi

53 Gyri temporales transversi

54 Gyrus temporalis superior

55 Sulcus temporalis superior

56 Gyrus temporalis mecius

57 Sulcus temporalis medius

58 Gyrus temporalis inferior

59 Sulcus temporalis inferior

60 Fissura collateralis

61 Gyrus fusiformis

62 Gyrus lingualis

63 L o b u $\mathrm{g}, 0$ c i pita 1 is

64 Polus occipitalis

65 Sulcus occipitalis transversus

66 Gyri occipitales superiores

67 Sulci occipitales superiores

68 Gyri occipitales laterales

69 Sulci occipitales laterales

$70 \mathrm{~L}$ o b u s p a r i e t 1 is

71 Lobulus parietalis sunerior

72 Sulcus interparietelis

73 Lobulus parietalis inferior

74 Gyrus supramarginelis

75 Gvrus angularis

76 Facies medialis hemisnhacri

77 Suicus corperis callcsi

78 Sulcus cinguli

79 Pars subrrontalis 

1 Pars marginalis

2 Sulcus subparietalis

3 Fissura hippocampi

4 Gyrus fornicatus

5 Gyrus cinguli

6 Isthmus gor fornicati

7 Gyrus hippocampi.

8 Uncus [Eyri hippocampi]

9 Substantia reticularis alba

10. Lobulus paracentralis

11 Praecuneus

12 Fissura parietooccipitalis

13 Fissura calcarina

14 Cuneus

15 C $\circ$ rpus c a 11 o s m

16 Splenium corporis callosi

17 Truncus corporis callosi

18 Genu corporis callosi

19 Rostrum corporis callosi

20 Lamina rostralis

21 Striae transversao

22 Stria longitudinalis medialis

23 Stria longitudinalis lateralis

24 Fasciola cinerea

26 Crus fornicis

$$
25 \mathrm{~F} \circ \mathrm{r} n \mathrm{i} x
$$

27 Corpus fornicis

28 Taenia fornicis

29 Columa fornicis

30 Pars libera columnae fornicis

31 Pars tecta columnae fornicis

$32 \mathrm{~s}$ e p t u m pe I l u c id u m

33 Lamina septi pellucidi

34 Cavum septi pellucidi

$$
35 \begin{array}{llllllllll}
V & \text { e } & n & t & i & c & u & l & u & s \\
& & a & t & e & r & a & 1 & i & s
\end{array}
$$

36 Pars centralis

37 Cornu anterius

38 Cornu posterius
39 Cornu inferius

40 Corpus striatum

41 Nucleus caudatus

42 Caput nuclei caudati

43 Cauda nuclei caudati

44 Stria terminalis

45 Lamina affixa

46 Taenia chorioidea

47 Lamina chorioidea epithelialis

48 Calcar avis

49 (Bulbus cornu posterioris

50 Eminentia collateralis

$\because 51$ Trigonum collaterale

52 Hippocampus

53 Fimbria hippocampi

54 Taenia fimbriae

55 Digitationes hippocampi

56 Fascia dentata hippocampi

57 Commissura hippocampi

$\therefore$.

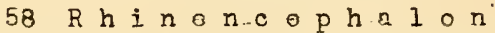

59 Sulcus parolfactorius anterior

$60 \mathrm{P} a r s$ a $n t$ e r i r r r encephali)

61 Lobus olfactorius

62 Bulbus olfactorius

63 Tractus olfactorius

64 Trigonum olfactorium

65 Stria medialis

66 Stria intermedia

67 Area parolfactoria [Brocae]

68 Sulcus parolfactorius posterior

69 p a r.s p o s t e r i r [rhinercephali]

70 Gyrus subcallosus Pedunculus corporis callosi]

71 Substantia perforata anterior

Stria olfactoria lateralis

73 Limen insulae

74 Sectiones telencephali

75 Substantia corticalis

76 Centrum semiovale

77 Decursus fibrarum cerebralium 

1 Fibrae arcuatae cerebri

2 Cingulum

3 Fasciculus longitudinalis superior

4 Fasciculus longitudinalis inferior

5 Fasciculus uncinatus

6 Radiatio corporis callosi

7 Pars frontalis

8 Pars parietalis

9 Pars temporalis

10 Pars occipitalis

11 Tapetum

12 ivucleus lentiformis

13 Putamen

14 Globus pallidus

15 Claustrum

16 Capsula externa

17 Capsula interna

18 Genu capsulae internee

19 Pars frontalis capsulae. interrae

20 Pars occipitalis capsulae internae

21 Nucleus amygdalae

22 Corona radiata

23 Pars frontalis

24 Pars parietalis

25 Pars temporalis

26 Pars occipitalis

27 Radiatio corporis striati

28 Radiatio occipitothalamica [Gratioleti]

29 Commissura anterior [cerebri]

31 Pars posterior

32 MENINGES
34 Falx cerebri

35 Tentoriun cercbelli

36 Falx cerebelli

37 Diaphragma sellae

38 Foramen diaphragmatis [sellae]

39 Incisura tentorii

40 Dura mater spinalis

41 Filum durae matris spinalis

42 Cavum epidurale

43 Cavum subdurale

44 Arachnoidea spinalis

45 Arachnoidea encephali

46 Cavum subarachnoideale

47 Cisternae subarachnoidales

48 Cisterna cerebellomedullaris

49 Cisterna fossae lateralis cerebri [Sylvii]

50 Cisterna chiasmatis

51 Cisterna interpeduncularis

52 Cisterno venae magnae cerebri

53 Granulationes arachnoideales

[Pacchioni]

54 Pia mater spinalis

55 Lig. denticulatum

56 Septum cervicale intermedium

57 Pia mater encephali

58 Tela choriodea ventriculi quarti

59 Plexus chorioideus ventriculi quarti

60 Tela chorioidea ventriculi tertii

61 Plexus chorioideus ventriculi tertii

62 Plexus chorioideus ventriculi lateralis

63 Glomus chorioideum

64 Acervulus

33 Dura mater encephali 



\section{S Y S T E MA N E R V ORU U P P IRIPRER I C U M}

$2 N E R V I C E R E B R A L E S$

3 NN. OLFACTORII

4 N. OPTICUS

5 N. CCULOMOTORIUS

6 Ramus superior

7 Ramus inferior

8 Radix brevis ganglii

ciliaris

\section{N. TROCHLEARIS}

10 Decussatio nervorum trochlearium

\section{N. TRIGEMINUS}

12 Portio major

13 Ganglion scmilunare Gasseri]

14 Portio minor

\section{N. ophthalmicus}

16 N. tentorii

17 N. lecrimalis

18 Ramus anastomoticus cum $n$. zygomatico

19 N. frontalis

$20 \mathrm{~N}$. supraorbitalis

21 Ramus frontalis

22 N. supratrochlearis

23 N. nasociliaris

24 Radix longa ganglii

$$
\text { ciliaris }
$$

25 Nn. ciliares longi

26 N. ethmoidalis postorior

27 N. ethmoidalis anterior

28 Rami nasales anteriores

29 Rami nasales

interni

30 Rami nasales laterales

31 Rami nasales mediales

32 Ramus nasalis externus
33 N. infratrochlearis

34 Ramus palpebralis superior

35 R. pripobalis inferior

$$
36 \text { G. c i I a } r \text { e }
$$

37 Nn. ciliares breves

39 N. meningeus [medius]

$40 \mathrm{~N}$. xygomaticus

41 Ramus zygomaticotemporalis

42 Ramus zygomaticofacialis

43 inn. sphenopalatini

44 in. alveolares superiores

45 Rami alveolares superiores posteriores

46 N. infraorbitalis

47 R. alveolaris superior meảius

48 Rami alveolares superiores anteriores

49 Plexus dentalis superior

50 Rami dentales superiores

51 Rami gingivales superiores

52 Rami palpebrales inferiores

53 Rarai nasales externi

54 Rami nasales interni

55 Rami labiales superiores

56 G a $n g l i \circ n$ s $p h$ e $n-$ o p a l a i n u m

57 Rami orbitales

58 N. canalis pterygoidei [Vidii]

59 N. peirosus superficialis major

60 N. peírosus profundus

61 Rami nasales posteriores

superiores laterales

62 Rami nasales posteriores superiores mediales 63 N. nasopalatinus [Scarpae! 

1 Rami nasales posteriores inferiores

2

[laterales]

3 N.palatinus anterior

$\leqslant \quad$ N.palatinus medius

5 N.palatinus posterior

6 N. mandibularis

7 H. Eptnoans

8 N. masticatorius

9 Momassetericus

$10 \mathrm{Nn}$. terporales profundi

11 T. temporalis profundus posierior

12 i. temporalis profundus enterior

13 T. buccinatorius

14 N. oterygoideus externus

$15 \mathrm{~N}$. pterygoideus internus

16 N. auriculotemporalis

$17 \mathrm{~N}$. mentus auditorii externi

$18 \mathrm{R}$. menbranae tympani

19 Remi parotidei

20 Rami ancstomotici curn $n$. faciali

21 In. auriculares snteriores

22 Rami temporales superficinles

23 N. linguslis

24. Rani isthmi faucium

25 Raini anastomotici cum $n$. hypoglosso

$26 \pi$. sublingualis

27 Romi linguales

28 N. alveolaris inferior

29 Plexus dentalis inferior

30 Remi dentoles inferiores

31 Rami gingivales inferiores

32 iv. mylohyoideus

33 N. mentalis

34 Romi mentales

35 Rami labinles inferiores

36 G a n $\mathrm{g} I$ i $\mathrm{n}$

o t i c u m

37 N. potrosus superficialis minor
$38 \mathrm{~N}$. tensoris veli palatini

39 iv. tensoris tympani

40 Ramus anastomoticus cum $n$. spinoso

41 R. anastomoticus cum $n$. auricin?0\%erporali

42 Ramus annstomoticus cum chorda tympani

43 G a $n$ g 1 i $\circ \mathrm{n}$ s u b m a x i 1 a re

4 Rami communicantes cum $n$. linguali

45 Rami subiaxillares

$$
\begin{aligned}
& 46 \text { N. ABDUCENS } \\
& 47 \text { N. FGCIALIS }
\end{aligned}
$$

48 Geniculua $n$. facial is

49 Genglion geniculi

50 ‥ s-apedius

51 Ramos cnestomoticus curi plexu tympenico

52 i. curicularis posterior

53 Rngus occipitalis

54 Renus digastricus

55 Remus stylohyoideus

56 Ramus enastonoticus cum $n$.

- glossopharyngeo

57 Plexus parotideus

58 Romi temporales

59 Rari zygomatici

60 Rami bucoaics.

61 Ramus merginalis mondibulae

62 Firnus colli

63 vi.intorned i us

64 Chorde tympani

65 N. ACUSTICUS

66 Fndix vestibularis

67 Radix cochlecris

68 Filn anstomotica

69 N. $\nabla$ e s t $i b$ u $I i$

70 Ganglion vostibulare 


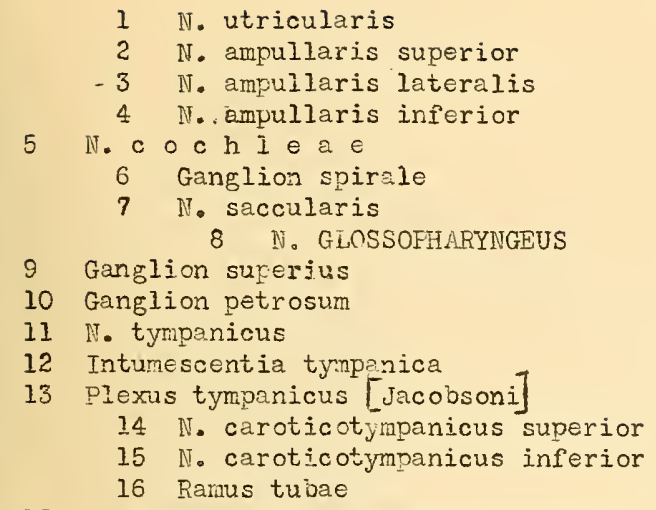

$17 R$. anastomoticus cum ramo auriculari n. $\operatorname{vag} i$

18 Rami pharyngei

19 Ramus stylopharyngeus

20 Rami tonsillares

21 Rami linguales

\section{IV. VAGUS}

23 Ganglion jugulare

24 Ganglion nodosum

25 Ramus meningeus

26 Ramus auricularis

27 R. anastomoticus cum n. glossopharyngeo

28 Rami pharyngei

29 Plexus pharyngeus

30 N. laryngeus superior

31 Rainus exterinus

32 Ramus internus

33 Ramus anastomoticus cum $n$. laryngeo inferiore

34 Rami cardiaci superiores

35 (N. depressor)

36 N. recurrens
37 Rami cardiaci inferiores

38 Rami tracheales

39 Rami oesuphagei

$40 \mathrm{~N}$. laryngeus inferior

41 Ramus anterior

42 Ramus posterior

43 Rami bronchiales anteriores

44 Rani bronchiales posteriores

45 Plexus pulmonalis anterior

46 Plexus pulmonalis posterior

47 Rami oesophagei

48 Plexus oesophageus anterior

49 Plexus oesophageus posterior

50 Rami gastrici

51 Plexus gastricus anterior

52 Plexus gastricus posterior

53 Rami hepatici

54 Rami coe?iaci

55 Raui lienales

56 Rarili renales

57 N. ACCESSORIUS

58 Ramus internus

59 Ramus exterinus

\section{IN. HYPOGLOSSUS}

61 Ramus descendens

62 Ansa hypoglossi

63 Famus thyreohyoideus

64 Rarij Iinguales

$6 \overline{5}$ N. S P I N A L E S

66 File radicularia

67 Fadix anterior

68 Radix posterior

69 Ganglion spinale

70 Ranus anterior

71 Ramus posterior

72 Ramus communicans

73 Famus meningeus

74 Cauda equina

75 Ansae 

2. Rami posteriores 1 Nn. cervicales

3 Ramus medialis

4. Ramus lateralis

5 N. suboccipitalis

6 N. occipitalis major

7 (N. occipitalis tertius)

8 Rami anteriores

9 P Lutex us c e $r$ vicalis

10 N. occipitalis minor

Il $N$. auricularis magnus

12 Ramus posterior

13 Ramus anteriur

14 N. cutaneus colli

15 Rami superiores

16 Rami inferiores

17 Nn. supraclaviculares

18 Nn. supraclaviculares anteriores

$19 \mathrm{Nn}$. supraclaviculares medii

$20 \mathrm{Nn}$. supraclaviculares posteriores

21 N. phrenicus

22 Ramus pericardiacus

23 Rani phrenicoabdominales

\section{PLEXUS BRACHIALIS}

25 P r s: su pracla $v i c u l-$ a $r$ is

$26 \mathrm{Nn}$. thoracales posteriores

$27 \mathrm{~N}$. dorsalis scapulae

28 N. thorecalis longus

$29 \mathrm{Nn}$. thoracales anteriores

30 N. subclavius

31 N. suprascapularis

32 Nn. subscapulares

33 N. thoracodorsalis

34 N. axillaris

35 Rami musculares

36 N. cutaneus brachii lateralis

37 P $r$ s in $f$ a c 1 a $v i c u-$

1 a $r$ is

38 Fasciculus lateralis

39 Fasciculus medialis

40 Fasciculus posterior
41 N. musculocutaneus

$\triangle 2$ Rami musculares lateralis

43 N. cutaneus antibrachii

$44 N$. cutaneus brachii medialis

45 N. cutaneus antibrachii medialis

46 Ramus volaris

47 Ramis ulnaris

49 Rami muscuiares

50 N. interosseus [antibrachii] voiaris

51 Rarnus palmaris $n$. mediani

52 Ramus anastomoticus cum $n$ ulnari

53 No. digitalos volares cormunes

$54 \mathrm{Nn}$. digitales volares proprii

55 N. ulnaris

56 Ramus cutaneus palmaris

57 Ramus dorsalis manus

$58 \mathrm{Nn}$. digitales dorsales

59 Ramus volaris manus

60 Ramus superficialis

$61 \mathrm{Nn}$, digitales volares communes

62 Nn, digitales volares proprii

63 Famus profundus

64 Rami musculares

65 No radialis

66 IV. cutaneus brachii posterior

67 Rami musculares

68 N. cutaneus artibrachii dorsalis

69 Ramus profundus

70 N. interosseus antibrachii dorsalis

71 Ramus superficialis

72 Ramus anastomoticus uInaris

$73 \mathrm{Nn}$. digitales dorsales

$$
74^{-} \text {Nn. thoracaifes }
$$

75 Rari posteriores

76 Ramus cutaneus lateralis

77 Ramus cutaneus medialis 

1 Rami anteriores [Nn. intercostales]

2 Rami musculares

3 Ramus cutaneus lateralis

[pectoralis et abdominalis]

4 Ramus posterior

5 Ramus anterior

6 Rami manmarii laterales

7 in. intercostobrachinles

8 Ramus cutaneus anterior. Jpect-

oralis et abdominalis

9 Rani mamarii nediales

10 In. Lumbales, sacrales, coccygeus

11 Nn. lumbales

12 Rami posteriores

13 Ramus medialis

14 Ramus lateralis

$15 \mathrm{Nn}$. clunium superiores

16 Rami anteriores

$17 \mathrm{Hn}$. sacrales et coccygeus:

18 Rami posteriores

19 Remus mericlis

20 Ramus leteralis

$21 \mathrm{Nn}$, clunium medii

22 P I F X US I U B O SACR I I S

24 Rami musculares

\section{PLEXUS LUIBAALIS}

\section{Rami musculares

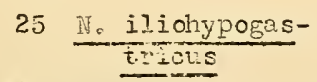 \\ 27 Ramus cutaneus lateralis \\ 28 Ramus cutaneus anterior}

30 Rami musculares

\section{9 iv. ilioinguinalis}

$31 \mathrm{Mn}$. scrotales anteriores

32 Nn. labiales anteriores

34 N. lumboinguinalis

33 N. genitofemoralis

35 N. spermaticus externus
36 N. cutaneus femoris lateralis

37 N. obturatorius

38 Ramus arterion -

39 Ramus cutaneus

40 Ramus posterior

41 N. femoralis

42 Rami cutanei anteriores

43 Rami musculares

44 N. saphenus

45 Ramus infrapatellaris

46 Fami cutanei cruris

mediales

47 PIFINS SACPAI. I

48 Truncus lumbesacralis

49 N. glutaeus superior

50 M. Glutaeus inferior

$51 \mathrm{~N}$. cutaneus femoris posterior $52 \mathrm{Nn}$. clunium inferiores

53 Rami perineales

54. No ischiadicus

55 Pami musculares

56 pervinaeus communis

57 Fami musculares

$58 \mathrm{~N}$. cutaneus surae lateralis

59 Ramus anastonoticus peronaeus

60 N. peronaeus superficialis

61 Rami musculares

62 N. cutaneus dorsalis medialis

63 N. cutaneus dorsalis internedius

$64 \mathrm{Nn}$. digitales dorsales pedis

65 N. peronaeus profundus

66 Kami musculares

67 in. digitales dorsales hallucis lateraits et

68 W. tibialis digiti secundi medialis 69 Rami musculares 

1 N. interusseus cruris

$2 N$. cutanous surae medialis

3 N. suraits

4 Rami calcanei laterales

$5 \mathrm{~N}$. cutaneus dorsalis

laterales

6 Rami calcanei mediales

7 N. plantaris medialis

8 No. digitales plantares commines

9 In. digitales plantares proprii

10 N. plantaris lateralis

11 Ramus superficialis 12 In. digitales plantares cormunes
13 Nn. digitales

plartares

proprii

14 Rasus pacinous

15 PLEXUS PUDENDUS

16 N. haenorrhoidales medii

$17 \mathrm{~N}$. vesicales inferiores

18 Nn. vaginales

19 iv. pudendus

$20 \mathrm{Nn}$. haemorrhoidales inferiores

$21 \mathbb{N}$. perinei

22 In. scrotales posteriores

23 Nn. Iabiales poster res

24 N. dorsalis penis

25 N. dorsalis clitoridis

26 II. COCCYGEUS

27 Plexus coccygeus

28 in. anococcygei

29 SYS TE MA NER VOR U IT S I HPATH I C U II

30 Truncus sympaticicas

31 Ganglia truei sympathici

32 Plexus sympalihici

33 Ganglia plexsum syinathicorum

34 PARS CEPHALICA ET GERVICALIS S. SYIPATIICI

35 Ganglion cervicale superius

36 N. jugularis

37 F. caroticus internus

38 Plexus caroticus internus

39 Plexus cavernosus

40 Plexus arterias cerebri anterioris

41 Plexus arteriae cercbri mediae

42 Plexus arteriae chorioideae

43 Plexus ophthalmicus

44 Radices sympathicae ganglii ciliaris

$45 \mathrm{Nn}$. carotici exierni

46 Plexus caroticus externus
47 Plexus thyteoideus superior

48 Plexus lingualis

49 Plezus maxillaris externus

50 Radix sympathica ganglii submaxillaris

51 Plexus occipitalis

52 Plexus quricularis posterior

53 Plexus temporalis superficialis

54 Plexus maxillaris internus

55 Flexus meningeus

56 Flexus caroticus communis

57 Rami laryngopharyngei

58 Plexus pharyngeus ascendens

59 N. cardiacus superior

60 Ganglion cervicale medium

61 T. carciacus medius

62 Ganglion cervicále inferius

63 Ansa subclavia [Vieussenii]

64 N. cardiaclis interior

65 Plezus submavilis

66 Pleyas maimarius interus

67 Flexus thyreoideus inferior

68 Plexus vertetrais 

1 PARS THORACALIS S. SYMPATHICI

2 Ganglia thoracalia

3 N. splanchnicus major

4 Ganglion splanchnicum

5 N. splanchnicus minor

$$
6 \text { Ramus renalis }
$$

(N. splanchnicus imus)

Plexus aorticus tinoracalis

Plexus cardiccus

10 Plexus coronarius cordis anterior

11 Ganglion cerdiacum [Trisbergi]

12 Plexus coronarius posterior

13 Rami pulmonales

14 Plexus pulmonalis

15 PARS ABDONINAIS FT PELTINAS. SVIPATHICI

16 Ganglia Ivibalia

17 Ganglia sacralia

18 Plexus aorticus abdominalis

19 Plexus coeliacus

20 Ganglia coeliaca.

21 Ganglion mesentericun superius

22 Plexus phrenicus

23 Ganglia phrenice.

24 Plexus phrenicus

25 Plexus lienalis

26 Plexus gastricus superior
27 Plexus gastricus inferior

28 Plexus suprarenalis

29 Plexus renalis

30 Plexus spermaticus

31 Plexus arteriae ovaricae

32 Plexus mesentericus superior

33 Plexus myentericus

34 Plexus submucosus

35 Plexus mesentericus inferior

$36 \mathrm{Nn}$. haemorrhoidales superiores

37 Plexus iliacus

38 Plexus iliacus

39 Plexus hypogastricus

$\triangle 0$ Plexus haenorrhoidalis medius

41 Plexus prostaticus

42 Plexus deferentialis

43 Plexus uterovaginalis

44 Plexus vesicalis

$45 \mathrm{Nn}$. vesicales superiores

46 In. vesicales inferiores

47 Plexus cavernosus penis

$48 \mathrm{~N}$. cavernosus penis major

49 Nn. cavernosi penis minores

50 Plexus covornosus clitoridis

5I $N$, cavernosus clitoridis major

$52 \mathrm{Nn}$. cavernosi clitoridis minores

53 Plexus femoralis

54 Plexus popliteus 

1 ORGAINA SENSUUE EI INTEGUTEMTUI CORTUIE

$20 R G A N O N V^{*} I S U S$

3 OCUIUS

4 OPTICUS

5 Vaginae $n$. optici

6 Spatia intervaginalio.

7 BULBUS OCULI

8 Polus anterior

9 Polus posterior

10 Aequater

11 Ieridiani

12 Axis oculi extern?

13 Axis oculi interna

14 Axis optice

15 [Linea $\nabla$ isus]

16 Vesicula ophthatris ${ }^{\mathrm{x}}$

17 Caliculus opithalmicus $x$

TUNICA FIBROSA CCUII

$$
19 \text { Sclera }
$$

20 Sulcus sclerse

21 Rima corneclis

22 Sinus venosus sclerae Canalis Schlemmi, Lauthi]

23 Lanina fusca

24 Ianina cribrosa sclerae

25 (Raphe sclerae)

26 (Funiculus sclerae

27 Cornea.

28 Annulus conjunctivac

29 Vertex corneac
30 Iimoris cornae

31 Fccies anterior

32 Facies posterior

33 Epitheliun cornene

34 Lamina elastica anterio: [Bormani]

35 Substantic propria

36 Iomina eisstica posterior Demoursi, Descemetj]

37 Encothelium camerae anterioris 38 TUNIC $A$ VASCULOS: OCUII 39 Chorio:dea

40 Lamina suprachorividea

41 Spatiun perichorioideale

42 Iamina vasculosa

S3 Lamina choriocapillaris

Af Lenine basalis

$\leq 5$ (Raphe chorioideae)

47 Corona ciliaris

48 Processus ciliares

49 Flicae cilizres

50 Orbiculus ciliaris

51 11. ciliaris

52 Iibrae meridionales [Erueckei]

53 Fibrae circulares [ivelleri]

54 Plözus gargliosus ciliaris

55 Iris

56 iargo pupillaris

57 liargo ciliaris

58 Facies nnterior 

1 Facies posterior

2 nnulus iridis major

3 Annulus iridis minor

4 Plicae iridis

5 Pupilla

6 iI. sphincter pupillse

7 . Strome iridis

8 ii. dilatator pupillne

9 Eig-poctinntum iridis

10 Spotia anguli iridis [Fontanae]

11 Circulus arteriosus major

12 Circulus erteriosus rainor

13 Nembrana pupillaris $x$

\section{STRATU: PIGTENTI}

15 Stratum pigmenti retinae

16 Stratum pigmenti corporis ciliaris

17 Stratum pigmenti iridis

\section{PETINA}

19 Pars optica retinae

20 Ora serrata

21 Pars ciliaris retinae

22 Papilla n. optici

23 Excavatio papillae n. optici

24. Incula lutea

25 Fovee centralis

$26 \mathrm{~V} \approx \mathrm{s}$ a. s a $\mathrm{n} g \mathrm{u}$ in $e$ a. $r e t i n \in e$

27 Circulus vasculosus n. optici [Halleri]

28 Arteriola [Venula] temporalis retinae ouperior

29 Arteriols. [Venula] temporalis retinae inferior

30 Arteriola [Venula] nasalis retince superior

31 Iteriola [Venule] nasalis retinae inferior

32 Arteriola [Venula] macularis superior

33 Arteriola [Venuli] macularis inferior

31 Arteriola [Venula] retince medialis

\section{CNIERA OCULI ANTERIOR}

36 Angulus iridis

37 CAITERA OCULI POSTERIOR

38 CORPUS VTTPEU:I

39 A. hyalcideax

40 Canalis hyaloidea

41 Tosse hyolnidea

42 Iembrona hyaloidea

43 Strona vitreum

44 Hanow viriseus

\section{LENS CRYSTALLIN}

46 Substantia lentis

47 Substantia corticalis

48 Nucleus Ientis

49 Fibrae lentis

50 Epitheliur lentis

51 Copsula lentis

52 Polus anterior lentis

53 Polus posterior lentis

54 Facics anterior lentis

55 Facies posterior lentis

56 Aris lentis

57 Aequator lentis

58 Radii Ientis

60 Fibrse zonulares

59 ZONULA CILIPIS [ZINNI]

61 Spatia zonularis

62 ORGANA OCUI ACCRSSORI:

63 Irusuli oculi, Fasciae orbitales

64 T० orbitatis

65 M. rectus superior

66 I. rectus inforior

67 I. rectus medielis

63 i. rectus laterolis

69 incertus musculi recti lateralis

70 Annulus tendineus communis [Zinni]

71 obliquus superior 

1 Trochlea

M. obliquus inferior

M. levator palpebrae superioris

Periobita

Septum orbitale

Fasciae musculares

Fascia bulbi [Tenoni]

Spitium interf sciale [renoni]
corpus adiposum orbit.e

\section{Supercilium}

\section{Falpebrae}

12 Palpebra superior

13 Falpeora superior

14 Facies anterior palpebrarum

15 Facies posterior palpebrarur

16 Rima palpeorarum

17 Comissura palpebrarum lateralis

18 Commissura palpebrarum medialis

19 Angulus oculi lateralis

20 Angulus oculi medialis

21 Limbi palpebrales anteriores

22 Limbi palpebrales posteriores

23 Tarsus superior

24 Tarsus inferior

25 Lig. palpebrale mediale

26 Raphe palpebralis lateralis

27 Glandulae tarsales Nieibomi 28 Sebum palpebrale

29 M. tarsalis superior

30 M. tarsalis inferior

\section{CONJUNCTIVA}

32 Plica semilunaris conjunctivae

33 Caruncula lacrimalis

34 Tunica conjunctiva bulbi

35 Tunica conjunctiva palpebrarum

36 Fornix conjunctivae superior

37 Fornix conjuctivae palpekrarum

$38 \mathrm{Gl}$. mucosae [Krausei]

39 Noduli lymphatici conjunctivales

40 (Pinguecula)
41 APPARATUS LACR IIALIS

42 Glandula lacrimalis superior

43 Glandula lacrimalis inferior

44 (ri. Iacrimales aocossorine)

45 Ductuli excretorii gl. lacrimalis

46 Rivus lacrinalis

47 Lecus lacrimnlis

48 Functa lacrimaliz

49 Duetus lacrimales

50 Popillae lacrimates

51 Ampulla ductus lacrimalis

52 Saccus laciimalis

53 Fornix sacei lacrimalis

54 Ductus nasolacrimalis

55 Plica lacrimalis [Hasneri]

56 Lacrinae

\section{O R G A N O A U D I T U S}

58 Auris interna

59 LABURINTHUS MEABRANACEUS

60 Ductus endolymphaticus

61 Saccus endolymphaticus

62 Ductus utriculosaccularis

63 U triculus

64 Ductus semicirculares

65 Ductus semicircularis superior

66 Ductus semicircularis posterior

67 Ductus semicircularis lateralis

68 Ampullae membranaceae

69 Sulcus ampulloris

70 Crista ampullaris

71 Ampulla membrancea superior

72 Ampulla mezbranacea posterior

73 fmpulla membran icos. Interal is

74 Sacculus

75 Ductus reuniens [ienseni]

76 Masilide aclistiuae. .

77 lfacula acustica utriculi

78 iracula acustica sacculi 

1 Otoconia

2 Endolympha

3 Perilymphi

4 Spatium perilymphaticum

5 Ductus perilymphatici

6 Ductus coch 1 e a $r$ is

7 Cascum cupulare

8 Caecun vestibulare

9 Lanina basilaris

10 Membrana vestibularis

$$
\text { [Reissneri] }
$$

11 Lig. spirale cochleae

12 Prominentia spiralis

13 Stria vascularis

14 Sulcus spiralis

15 Labium tympanicum

16 Foramina nervosa

17 Labium vertibulare

18 Ganglion spirale cochleae

19 Organon spirale [Cortii]

$20 \mathrm{~V}$ a s a a u ris

internae

21 A. auditiva interna

22 Rami vestibulares

23 Ramus cochleae

24 Glomeruli arteriosi cochleae

$25 \mathrm{~V}$. auditivae internae

26 V. spiralis modioli

27 Vas prominens

$28 \mathrm{Vv}$ vestibularejs

$29 \mathrm{~V}$. aquaeductus vestibuli

$30 \mathrm{~V}$. canaliculi cochleae

\section{LABYRINTHUS OSSEUS}

\section{Vestibulum}

33 Recessus sphaericus

34 Recessus ellipticus

35 Crista vestibuli

$3 \overline{6}$ Pyramis vestibuli

37 Recessus cochlearis

38 Maculae eribrosae

39 Wacula cribrosa superior

40 Macula cribrosa media

41 Macula cribrosa inferior
43 Canalis semicircularis superior

44 Canalis semicircularis posterior

45 Canalis semicircularis lateralis

46 Ampullae osseae

47 Ampuila ossea superior

48 Ampuila ossea posterior

49 Ampulla ossea lateralis

50 Crura ampullaria

51 Crus commune

52 Crus simplex

\section{Cochlca}

54 Cupula

55 Basis cochlorie

56 Canalis spiralis cochleae

57 Modiolus

58 Basis modioli

59 Lamina modioli

60 Lamina spiralis ossea

61 Hamulus laminae spiralis

62 Scala tvestibuli

63 Scala tympani

64 Helicotrema

65 Lamina spiralis secundasia

66 Canalis spiralis modioli

67 Canales longitudinales modioli

68 Meatus acusticus internus

69 Porus acusticus int ernus

70 Fundus meatus acustici interni

71 Crista transversa

72 Area $n$. facialis

73 Area cochleae

74 Tractus spiralis foraminosus

75 Area vestibularis superior

76 Area vestibularis inferior

77 Foramen singulare

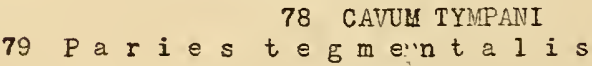




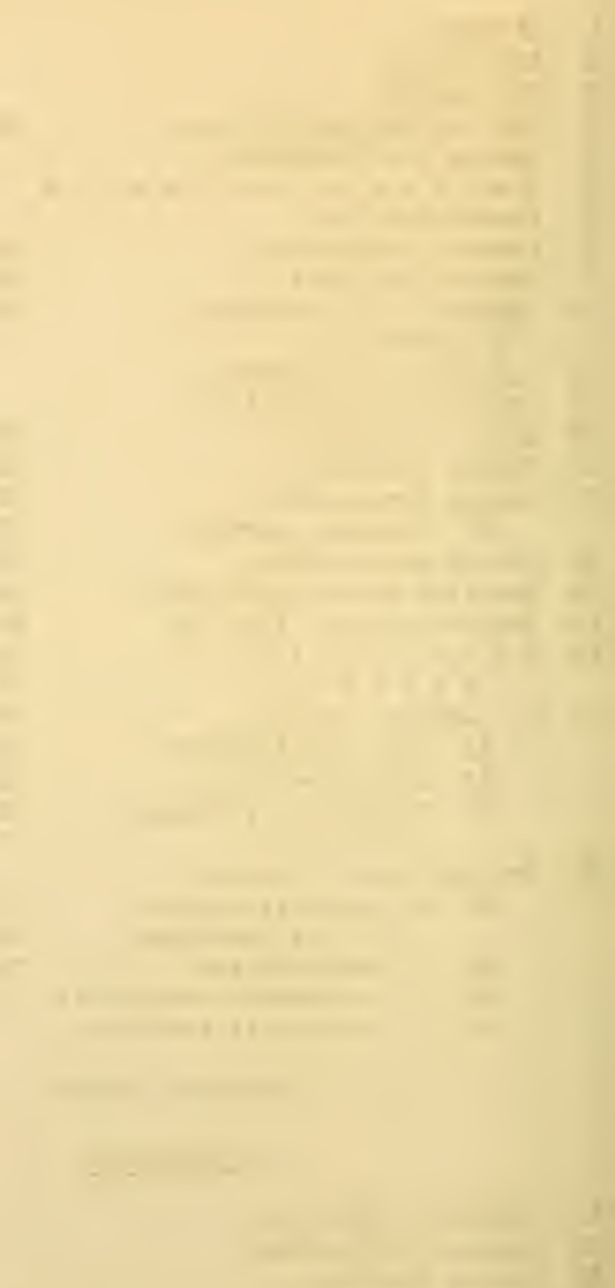

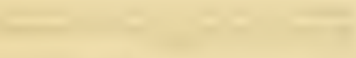
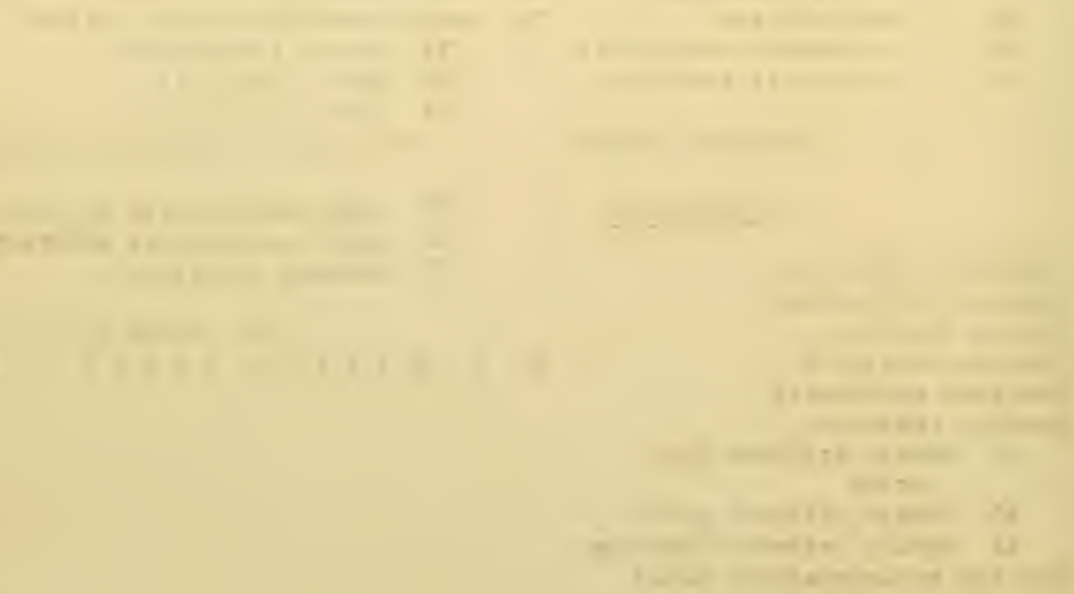
I Recessus epitympanicus

2 Pars cupularis

3 Paries jug $\mathrm{u} 1$ a $r$ is

4 Prominentia styloidea

5 Paries 1 a by $r$ int $h$ i c a

6 Fenestra vestibuli

7 Fossula fenestrae vestibuli

8 Promontorium

9 Sulcus promontorii

10 subiculum promontorii

II Sinus tympani

12 Fenestra cochleae

13 Fossula fenestrae cochleae

14 Crista fenestrae cochleae

15 Processus cochleariformis

$16 \mathrm{p}$ a $\mathrm{r} i \in \mathrm{s} \mathrm{m}$ a $\mathrm{s}$ o $\mathrm{i} d \mathrm{e} a$

17 Antrum tympanicum

18 Prominentia canalis semicircularis lateralis

19 Prominentia canalis facialis

20 Eminentia pyramidalis

21 Fossa incuais

22 sinus posterior

23 Apertura tympanica: canaliculi chordae

24 Cellulae mastoideae

25 Cellulae tympanicae

26 P a $r i e s$ c a $r \circ t i c a$

यi $P$ a $r$ e s/mem bran a e a

28 Niembrana tympani

29 Pars flaceida

$30 \quad P$ ars tensa

31 Limbus membranae tympani

32 Plica malleolaris anterior

33 Plica malleolaris posterior

34 Prominentia nalleolaris

35 Stria malleolaris

36 Umbo membranae tympani

37 Stratum cutareum

38 Annulus fibrocartilagineus
39 Stratum radiatum

10 . Stratur circulare

41 Stratum mucosum

42 OSSICULA AUDTTUS

43 s t a $p$ e $s$

44 Capitulum stapedis

45 Crus anterius

1ô Crus posterius

47 Basis stapedis

48 I $n$ o u s

49 Corpus incudis

50 Crus longum

51 P rocessus lenticularis

52 Crus breve

53 II a I l e u s

54 Lanubrium mallei

55 Capitulum Ilallei

56 Collum mallei

57 Processus lateralis

58 Processus anterior [Folii]

59 Articulationes ossiculorum auditus

60 Articulatio incudomalleolaris

61 Articulatio incu dostapedia

62 Syndesmosis tympanostapedia

63 Ligg, ossiculorum

64 Lig. mallei anterius

65 Lig. mallei superius

65 Lig. mallei laterale

67 Lig. incudis superius

68 Lig. incudis posterius

69 Membrana obturatoria (stapedis)

70 Lig. annulare baseos stap edis

71 Fin fixat or baseos stapedis]

72 Lusculi ossiculorum äiditus

73 H. tensor tympani

74 U. stapedius 

1 Tunica mucosa tymparica (GI. tympanicas)

Plica malleolaris posterior Plica malleolaris anterior

Recessus membranae tympani anterior

Recessus tympani membranae superior

7 Recessus membranae tympani posterior

8 Plica incudis

9 Plica stapedis

10 Membrana tympani secundaria

11 TUBA AUDITIVA [EUSTACHI]

12 Ostium tympanicum tubae auditivae

13 Pars ossea tubae auditivae

14 Isthrius tudae auditivae

15 Cellulae pneumaticae tubariae

16 Pars cartilaginae tubae auditivae

17 Cartilago tubae auditivae

18 Lamina [cartilaginis]

19 Lamina [cartilaginis] lateralis

20 Lamina membranācea

21 Tunica mucosa

22 Gl. mucosae

23 Noduli lymphatici tubarii

24 Ostium pharyngeum tubae auditivae

25 PEATUS ACUST ICUS EXTERNUS

26 Porus acusticus externus

27 Incisura tympanica [Rivini]

28 ifeatus acusticus externus cartilagineus

29 Cartilago meatus acustici

30 Incisurae cartilaginis meatus acustici externi [Santor

31 Lamina tragi
32 AURICULAE

33 Lojulus auriculae

34 Cartilago auriculae

35 Helix

36 Crus helicis

37 Spina helicis

38 Cauda helicis

39 Anthelix

40 Fossa triangularis [auriculae]

41 Crura anthelicis

42 Scapha

43 Concha auriculae

44 Cymba conchae

45 Cavum conchae

46 Antitrogis

47 Tragus

48 Incisura anterior [auris]

49 Incisura intertragica

50 (Tubsrculum auriculae [Darwini])

51 (Apex auriculae Darmini)

52 Sulcus auriculae posterior

53 (Tuberculum supratragicum)

54 Isthmis cartilaginis auris

55 Incisura terminalis auris

56 Fissura antitragohelicina

57 Sulcus anthelicis transversus

58 Sulcus cruris helicis

59 Fossa anthelicis

60 Eminentia conchae

61 Eminentia scaphae

62 Eminentia fossae triangularis

63 Ligg. auricularia [Valsalvae]

64 Lig. auriculare anterius

65 Lig. auriculare superius

66 Lig. auriculare posterius

67 M. helicis major

68 M. helicis minor

69 M. tragicus

70 (i. pyramidalis aurioulao. [Jungi

71 H. antitragicus

72 i!. transversus auriculae

73 M. obliquus auriculae

74 (i.. incisurae helicis [Santorini]) 



\section{ORGANON OLFACTUS}

2 ORGANON GUSTUS

3 Calyculi gustatorii

4 I $n t e g u m e n t u m$

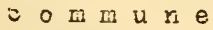

6 Sulci cutis

\section{CUTIS}

7 Cristae cutis

8 Retinacula cutis

9 Toruli tactiles

10 Foveola coccygea

11 Lig. caudale

12 Epidermis

13 Stratum corneum

14 Stratum germinativu [lialpighii]

\section{Coriim}

16 Tunica propria

17 Corpus papillare

18 Papillae

\section{Tela Subcutanea}

20 Penhiculus adiposus

21 Corpuscula nervorum terminalia

22 Corpuscula bulboidea [Krausii]

23 Corpuscula lamellosa [Vateri, Pacini]

24 Corpuscula tactus [Meissneri]

25 Corpuscula nervoruia genitalia

26 Corpuscula nervorum articularia

$$
\begin{array}{ll} 
& \multicolumn{2}{c}{27 \text { PILI }} \\
28 & \text { Lanugo } \\
29 & \text { Capilli } \\
30 & \text { Supercilia } \\
31 & \text { Cilia }
\end{array}
$$

32 Sarba

33 Tragi

34 Vibrissae

35 Hirci

36 Pubes

37 Folliculus pili

38 Fundus folliculi pili

39 Collum folliculi pili

40 Papilla pili

41 Scapus pili

42 Radix pili

43 Bulbus pili

44 Nin. arrectores pilorum

45 Flumina pilorum

46 Vortices pilorum

47 (Vortex coccygeus)

48 UNGTUES

49 Matrix unguis

50 Cristae matricis unguis

51 Sulcus matricis unguis

52 Vallum unธนis

53 Corpus unguis

54 Radix unguis

55 Lurula

56 ifargo occultus

57 Nargo liber

58 largo lateralis

59 Stratum corneum unguis

60 Stratum germinativu unguis

61 GLANDILAE CUTIS

62 G1.. glnmiformes

$63 \mathrm{Gl}$. sudoriferae

64 Corpus gl. sudoriferae

65 Ductus sudoriferus

66 Forus sudoriferus

57 Sudor

68 Gl. Ciliares [Nolli]

69 G1. circumanales 

1 GI. ceruminosae

2 Cerumen

3 Glandulae sebaceae

4 Sebum cutaneum

5 Míma

6 Papilla mainrae

7 Corpus maminae

8 Lobi mamrae

9 Lobuli marama
10 Ductus lactiferi

11 Sinus lactiferi

12 Lac femininum

13 Colostrum

14 Areola mame

$15 \mathrm{Gl}$. sebaceae

16 G]. areolares [tontgomerii]

17 a m a virilis

18 (Nammae accessoriae muliebres et virileş) 



\title{
1 BEGIOINS CORPORIS HUMANI
}

Auctoribus Me $r k$ l, $R$ ü $d$ n $g$ e r, Tol d t.
2 Linea mediana anterior
3 Linea nediana pusterior
4 Linea sternalis
5 Linea parasternalis

\begin{abstract}
6 Linea mamillaris
7 Linea axillexis

8 Linea scapularis
\end{abstract}



I Regiones capitis

2 Regio frontalis

3 Regio supracrittalis

4 Regio parietalis

5 Regio occipitalis

6 Regio temporalis

7 Regio auricularis.

8 Regio mastoidea

9 Regiones faciei

I) Regio nasalis
21 Recio parotideomasseterica 22 Fossa retromandibularis

23 Regiones colli

24 Regio colli anterio5

25 Regio submentalis

26 Regio hyoidea

27 Regio subhyoidea

28 Regio laryingea

29 Regio thyzeoiclea

30 Regio supresternalis
11 Regio oralis

12 Regio labialis superior

13 Regio labialis inferior

14 Regio mentalis

15 Regio orbitalis

16 Regio palpebralis superior

17 Regio palpebralis inferior

18 Regio infraorbitalis

19 Regio buccalis

20 Regio zygomatica
31 Fossa jugularis

32 Regio submoxillaris

33 Fcssa carotica

34 Regio sternocleid omastoidea

35 Fossa supraclavicularis mino:

36 Regio colli lateraiis

37 Fossa supraclavicularis major

38 Trigonum omoclaviculare

39 Regio colli posterior

40 Regio nuchae 

1 Fovea nuchae

2 R e giones p e ctoris

3 Regio pectoris anterior

4 Regio sternalis

5 Regio clavicularis

6 Regio infraclavicularis

7 Trigenum deltoideopectorale

8 Regio mamalis

9 Regio inframammalis

10 Regio pectoris lateralis

II Regio axilzaris

12 Fossa axillaris
24 Regio mediana dorsi

25 Regio interscapularis

26 Regio scapularis

27 Regio suprascapilaris

28 Fegio infrascapularis

29 Regio I untra? is

30 Regio coxae

31 Regio sicralis

32 Regio gluizea

33 Regio perinealis

34 Regio ara.lis

35 Regio urogenitalis
13 Regio costalis lateralis

$14 \pi$ e gion e $s$ a b d on $\ln i s$

15 Regio epigastrica

16 Regio hypochondriaca

17 Regio mesogastrica

18 Regio umbilicalis

19 Regio abdominalis lateralis

20 Regio hypogastrica

21 Regio pubica

22 Regio inguinalis

23

$R$ e $g i o n$ e $s$ d $r s i$
36 Regio pudendalis

37 Regiones extremi-

$t a t i s s u p$ o $\mathrm{s}$ i oris

38 Regio acromialis

39 Regio deltoicea

40 Regio brachii lateraitis

41 Regio brachii medialis

42 Regio brachii anterior

43 Regio brachii posterior

44 Regio cubiti anterior

45 Fossa cubitalis 

1 Regio cubiti posterior 2 Regio olecrani

3 Regio cubiti lateralis

4 Regio cubiti medialis

5 Regio antibrachii volaris

6 Regio antibrachii dorsalis

7 Regio antibrachii radialis

8 Regio antibrachii uinaris

9 Regio dorsalis mus

10 Regio volaris manus

11 Regiones digitales manus

12 Regiones dorsales digitorum

13 Regiones unguiculares

14 Regiones volares digitorum

$15 \mathrm{Reg} i \circ \mathrm{n} s$ of $t$ he $i \mathrm{n}$ ferior extremity

16 Regio femoris anterior

17 Fossa subinguinalis

18 Regio femoris lateralis

19 Regio trochanterica

20 Regio femoris posterior
21 Regio femoris medialis

22 Regio genu anterior 23 Regio pateliaris

24 Regio genu posterior 25 Fossa poplitea

26 Regio cruris anterior

27 Regio cruris posterior 28 Regio suralis

29 Regio cruris iateralis

30 Regio cruris medialis

31 Regio malleolaris lateralis

32 Regio malleolaris medialis

33 Regio retromalleolaris lateralis

34 Regio retromalleolaris nedialis

35 Regio calcanea

36 Regio dorsalis pedis

37 Regio plantaris pedis

38 Regiones digitales pedis

39 Regiones dorsales digitorum pedis

40 Regiones unguiculares

41 Regiones plantares digitorum pedis 






\section{COLUMBIA UNIVERSITY LIBRARIES}

This book is due on the date indicated below, or at the expiration of a definite period after the date of borrowing, as provided by the rules of the Library or by special arrangement with the Librarian in charge.

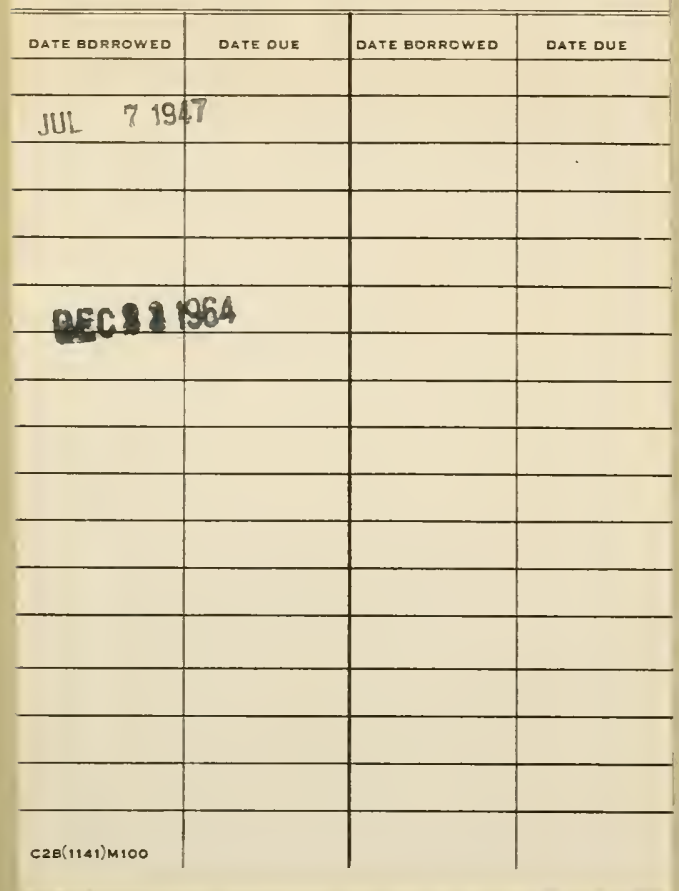


QM8

$\operatorname{Ln} 6$

$\because \cdots$ 
